\title{
HYDROGEOLOGY AND STEADY-STATE SIMULATION OF GROUND-WATER FLOW IN THE SAN JUAN BASIN, NEW MEXICO, COLORADO, ARIZONA, AND UTAH
}

By John Michael Kernodle

\author{
U.S. GEOLOGICAL SURVEY \\ Water-Resources Investigations Report 95-4187
}

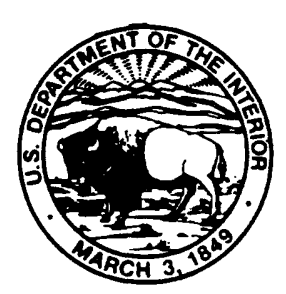

REGIONAL AQUIFER-SYSTEM ANALYSIS

Albuquerque, New Mexico

1996 


\title{
U.S. DEPARTMENT OF THE INTERIOR \\ BRUCE BABBITT, Secretary
}

\author{
U.S. GEOLOGICAL SURVEY \\ Gordon P. Eaton, Director
}

The use of firm, trade, and brand names in this report is for identification purposes

only and does not constitute endorsement by the U.S. Geological Survey.

For additional information write to:

Copies of this report can be purchased from:

District Chief

U.S. Geological Survey

Water Resources Division

4501 Indian School Road NE, Suite 200

Albuquerque, NM 87110-3929
U.S. Geological Survey

Branch of Information Services

Box 25286

Denver, CO 80225-0286 


\section{CONTENTS}

Abstract

Introduction

Purpose and scope ...............................................................................................................

Description of the study area ........................................................................................................ 3

Population and economy .................................................................................................................. 3

Previous investigations ........................................................................................................... 5

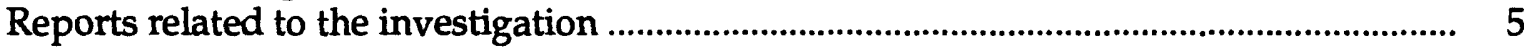

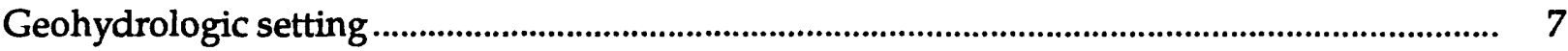

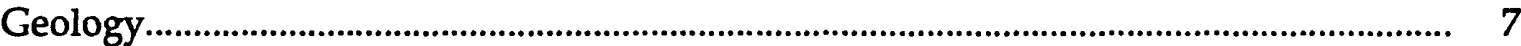

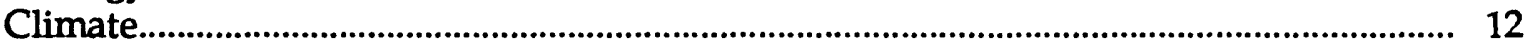

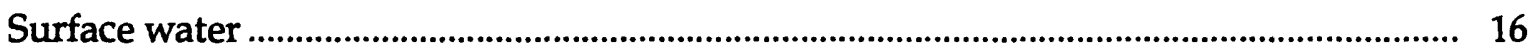

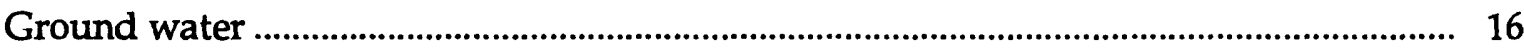

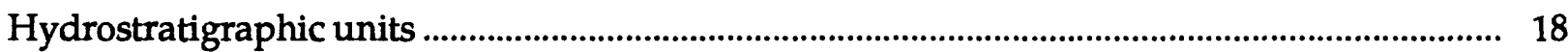

Alluvium and other Quaternary deposits ............................................................................ 19

Lithology ............................................................................................................. 19

Hydraulic properties................................................................................................. 19

Chuska Sandstone

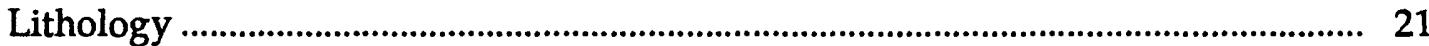

Hydraulic properties.................................................................................................. 21

San Jose Formation ................................................................................................ 21

Geometry and lithology .......................................................................................... 21

Hydraulic properties..................................................................................................... 22

Animas and Nacimiento Formations ............................................................................ 22

Geometry and lithology .......................................................................................... 24

Hydraulic properties............................................................................................................ 26

Ojo Alamo Sandstone .................................................................................................. 26

Geometry and lithology .......................................................................................... 28

Hydraulic properties.................................................................................................. 28

Kirtland Shale and Fruitland Formation ....................................................................... 28

Geometry and lithology .......................................................................................... 29

Hydraulic properties................................................................................................. 29

Pictured Cliffs Sandstone.............................................................................................. 32

Geometry and lithology ..................................................................................... 32

Hydraulic properties.......................................................................................................... 34

Lewis Shale ........................................................................................................... 34

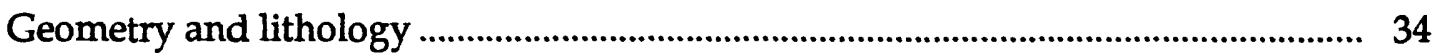

Hydraulic properties........................................................................................................... 34 


\section{CONTENTS--Continued}

Cliff House Sandstone.

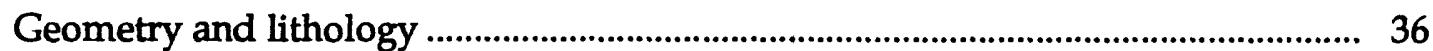

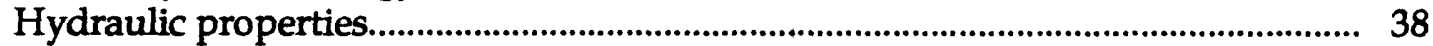

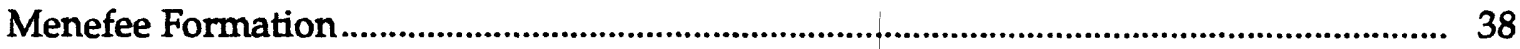

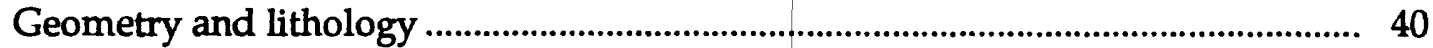

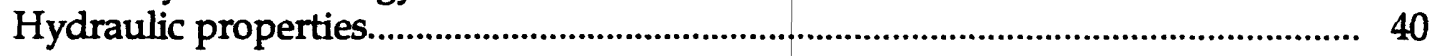

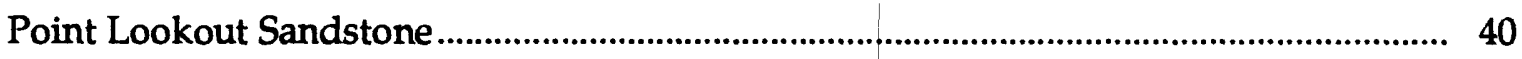

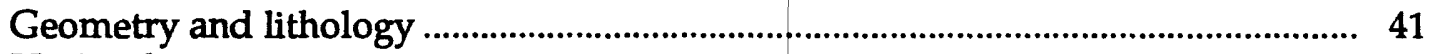

Hydraulic properties............................................................................................ 41

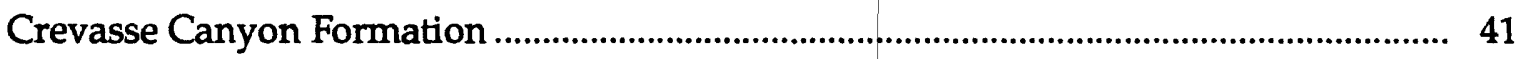

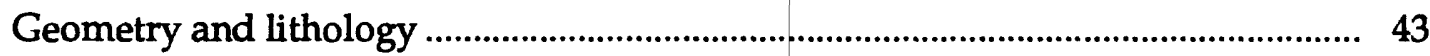

Hydraulic properties...................................................................................................... 43

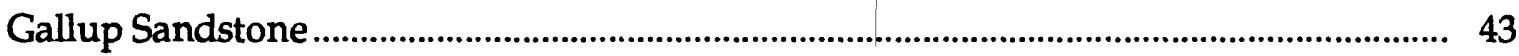

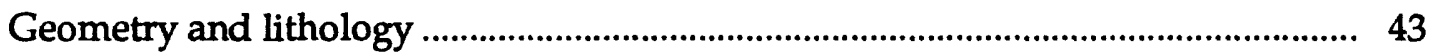

Hydraulic properties................................................................................................... 44

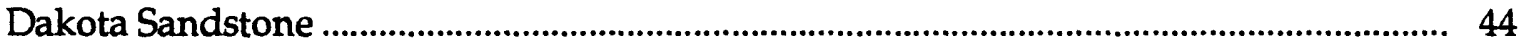

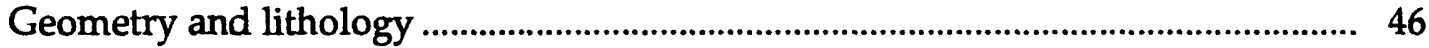

Hydraulic properties............................................................................................... 46

Morrison Formation.............................................................................................. 48

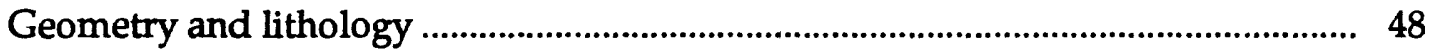

Hydraulic properties............................................................................................. 51

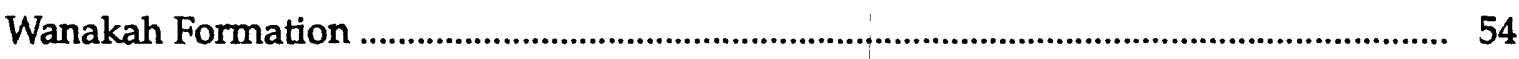

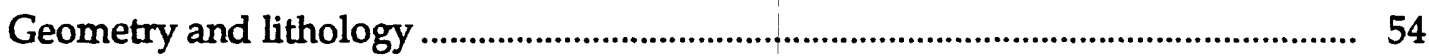

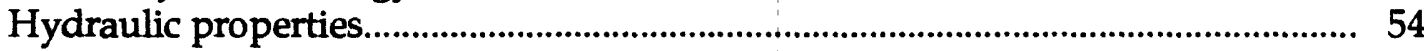

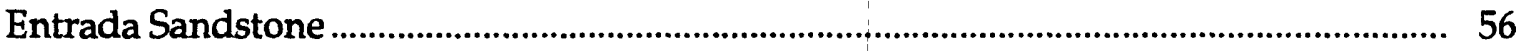

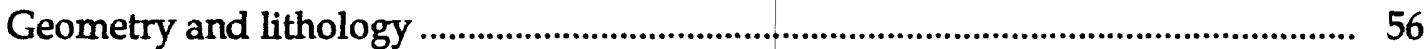

Hydraulic properties...................................................................................... 56

Natural boundaries of the ground-water-flow system ...................................................... 57

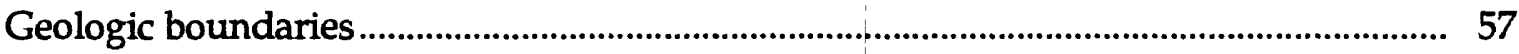

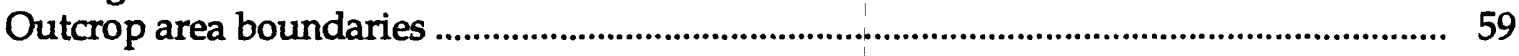

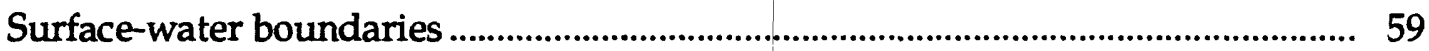

Recharge from precipitation .................................................................................... 59

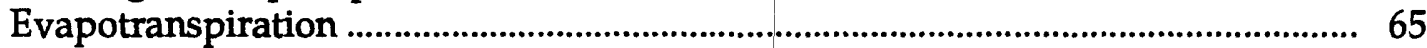

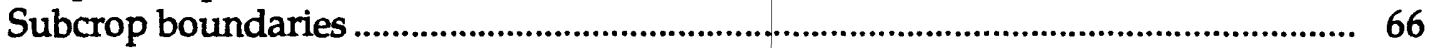

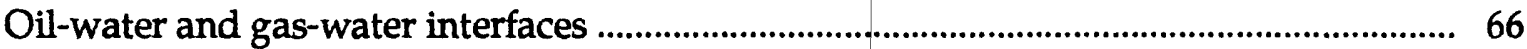

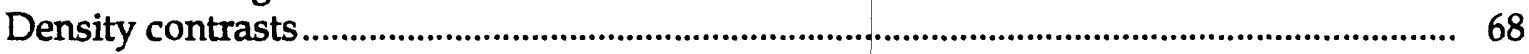




\section{CONTENTS--Concluded}

Description of the model

Flow equation, assumed conditions, and computer programs.......................................... 69

Representation of boundaries ................................................................................................. 70

Distributed recharge from precipitation ................................................................... 74

Stream-aquifer interaction .................................................................................... 74

Internal geometric boundaries ....................................................................................... 75

Subcrop boundaries ...................................................................................................... 75

Simulated hydraulic properties ........................................................................................ 79

Model calibration and sensitivity analysis................................................................................. 89

Preconditioned hydraulic-head distribution ...................................................................... 91

Model refinements and sensitivity to changes in simulated aquifer properties............... 91

Discussion of simulation analyses........................................................................................ 92

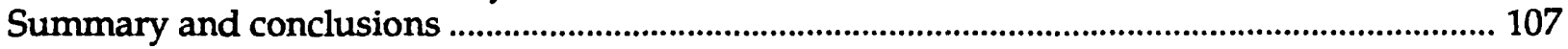

Selected references ............................................................................................................................ 108

\section{FIGURES}

Figures 1-4. Maps showing:

1. Location of the Regional Aquifer-System Analysis areas of

investigation.......................................................................................... 2

2. Location of Colorado Plateau, San Juan structural basin, and study area

3. Estimated 1985 population density in the San Juan Basin ........................... 6

4. Structural elements of the San Juan Basin and adjacent areas ...................... 8

5. Diagram showing time- and rock-stratigraphic framework and nomenclature ... 9

6. Generalized hydrogeologic section of San Juan Basin showing major aquifers, confining beds, and direction of ground-water flow ......................... 10

7-14. Maps showing:

7. Major faults in the San Juan Basin ........................................................... 11

8. Mean annual precipitation for the period 1931-60 ...................................... 13

9. Mean winter precipitation for the period 1931-60......................................... 14

10. Potential mean annual evaporation..................................................... 15

11. Location of streams simulated in the model ............................................. 17

12. Distribution of Quaternary deposits ........................................................... 20

13. Approximate altitude and configuration of the base of the Animas and Nacimiento Formations.................................................................... 23

14. Approximate thickness of the San Jose, Animas, and Nacimiento Formations 


\section{FIGURES--Continued}

Figures 15-34. Maps showing:

15. Approximate altitude and configuration of the top of the

Ojo Alamo Sandstone.

16. Approximate thickness of the combined Kirtland Shale and

Fruitland Formation

17. Approximate altitude and configuration of the top of the

Kirtland Shale

18. Approximate altitude and configuration of the top of the Pictured Cliffs Sandstone

19. Approximate altitude and configuration of the top of the

Lewis Shale.

20. Approximate altitude and configuration of the top of the

Cliff House Sandstone

21. Approximate altitude and configuration of the top of the

Menefee Formation.

22. Approximate altitude and configuration of the top of the

Point Lookout Sandstone

23. Approximate altitude and configuration of the top of the

Gallup Sandstone

24. Approximate altitude and configuration of the top of the

Dakota Sandstone

25. Approximate altitude and configuration of the top of the

Morrison Formation

26. Approximate thickness of the Morrison Formation

27. Location of uranium extraction sites in the Grants uranium belt

28. Approximate altitude and configuration of the top of the

Wanakah Formation

29. Location of major dikes in the San Juan Basin

30. Location of drainage basins used to determine the rainfall-altituderunoff relation for the San Juan Mountains

31. Surface-water drainage basins and the division of the San Juan

Basin into three rainfall-runoff regimes

32. Range of estimated direct recharge.

33. Location of oil, gas, and water wells completed in the Gallup Sandstone and Tocito Sandstone Lentil

34. Finite-difference model grid and locations of hydrogeologic sections shown in figures 37 and 38

35. Perspective view of the finite-difference model grid

36. Diagram showing correlation of geologic units and model layers 


\section{FIGURES--Continued}

Figure 37. West to east sections showing the vertical layers used in the model:

A. West to east section along 35 degrees 30 minutes latitude.............................. 76

B. West to east section along 35 degrees 45 minutes latitude............................... 77

C. West to east section along 36 degrees latitude................................................ 77

D. West to east section along 36 degrees 15 minutes latitude.............................. 77

E. West to east section along 36 degrees 30 minutes latitude .............................. 78

F. West to east section along 36 degrees 45 minutes latitude............................... 78

G. West to east section along 37 degrees latitude ................................................ 78

H. West to east section along 37 degrees 15 minutes latitude.............................. 79

38. South to north sections showing the vertical layers used in the model:

A. South to north section along 107 degrees longitude..................................... $\quad 80$

B. South to north section along 107 degrees 15 minutes longitude ................... 81

C. South to north section along 107 degrees 30 minutes longitude .................... 81

D. South to north section along 107 degrees 45 minutes longitude.................... 81

E. South to north section along 108 degrees longitude .................................... 82

F. South to north section along 108 degrees 15 minutes longitude .................... 82

G. South to north section along 108 degrees 30 minutes longitude.................... 82

39. Map showing location of the general-head boundary used to simulate the downward movement of water from the Chuska Sandstone, Deza

Formation, and landslide deposits into the regional aquifers

40. Maps showing simulated horizontal and vertical hydraulic conductivities for the:

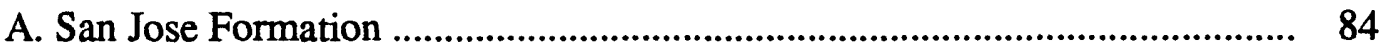

B. Animas and Nacimiento Formations .......................................................... 84

C. Combined Ojo Alamo Sandstone, Kirtland Shale, and Fruitland

Formation (vertical only) ............................................................................ 85

D. Pictured Cliffs Sandstone …....................................................................... 85

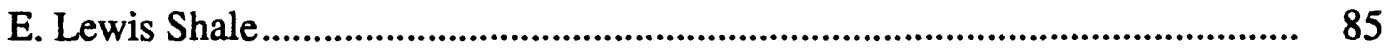

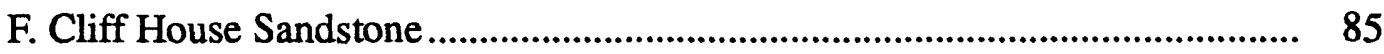

G. Menefee Formation ......................................................................... 86

H. Point Lookout Sandstone, Hosta Tongue, and Crevasse

Canyon Formation .................................................................................. 86

I. Gallup Sandstone and Mancos Shale .......................................................... 86

J. Dakota Sandstone ............................................................................................ 86

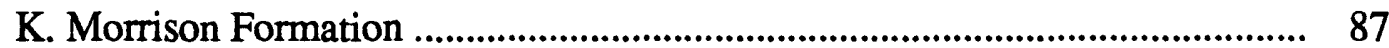

41. Map showing simulated horizontal hydraulic conductivity for the combined Ojo Alamo Sandstone, Kirtland Shale, and Fruitland Formation...................... 88

42. Map showing simulated horizontal transmissivity and upward vertical hydraulic conductivity for the Entrada Sandstone. 


\section{FIGURES--Concluded}

Figures 43-53. Maps showing computed steady-state head in the:

43. San Jose Formation

44. Animas and Nacimiento Formations

45. Combined Ojo Alamo Sandstone, Kirtland Shale, and

Fruitland Formation

46. Pictured Cliffs Sandstone

47. Cliff House Sandstone

48. Menefee Formation.

49. Point Lookout Sandstone

50. Gallup Sandstone

51. Dakota Sandstone

52. Morrison Formation

53. Entrada Sandstone

54. Maps showing vertical flow directions between selected adjacent hydrostratigraphic units in the San Juan Basin:

A. San Jose Formation and the Animas and Nacimiento Formations

B. Animas and Nacimiento Formations and the combined Ojo Alamo

Sandstone, Kirtland Shale, and Fruitland Formation.

104

C. Combined Ojo Alamo Sandstone, Kirtland Shale, and Fruitland

Formation and the Pictured Cliffs Sandstone

105

D. Pictured Cliffs Sandstone and the Cliff House Sandstone

E. Cliff House Sandstone and the Point Lookout Sandstone

105

F. Point Lookout Sandstone and the Gallup Sandstone. 105

G. Gallup Sandstone and the Dakota Sandstone

H. Dakota Sandstone and the Morrison Formation 106

I. Morrison Formation and the Entrada Sandstone 106 


\section{CONVERSION FACTORS AND VERTICAL DATUM}

Multiply

LENGTH

inch

foot

mile

foot per day

AREA

square mile

foot squared per day

VOLUME

cubic foot

acre-foot

cubic foot per second

gallon per minute

gallon per minute per

foot

gallon per day per foot

squared
By

0.02540

0.3048

1.609

0.3048

2.590

43,560 .

0.09290

0.02832

7.48

1,233

43,560

448.8

0.00006309

0.2070

0.04075
To obtain

meter

meter

kilometer

meter per day

square kilometer

square foot

meter squared per day

cubic meter

gallon

cubic meter

cubic foot

cubic meter per second

gallon per minute cubic meter per second liter per second per meter

meter per day

Temperature in degrees Celsius $\left({ }^{\circ} \mathrm{C}\right)$ can be converted to degrees Fahrenheit $\left({ }^{\circ} \mathrm{F}\right)$ as follows:

$$
{ }^{\circ} \mathrm{F}=9 / 5\left({ }^{\circ} \mathrm{C}\right)+32
$$

Sea level: In this report, "sea level" refers to the National Geodetic Vertical Datum of 1929 --a geodetic datum derived from a general adjustment of the first-order level nets of the United States and Canada, formerly called Sea Level Datum of 1929. 


\title{
HYDROGEOLOGY AND STEADY-STATE SIMULATION OF GROUND-WATER FLOW IN THE SAN JUAN BASIN, NEW MEXICO, COLORADO, ARIZONA, AND UTAH
}

\author{
By John Michael Kernodle
}

\section{ABSTRACT}

As part of a multidisciplinary regional aquifer-system analysis, a three-dimensional steadystate ground-water-flow model was constructed for the San Juan Basin in parts of New Mexico, Colorado, Arizona, and Utah. The model simulated ground-water flow in 12 hydrostratigraphic units representing all of the major sources of ground water from aquifers of Jurassic and younger age.

Ten map reports in the U.S. Geological Survey Hydrologic Investigations Atlas 720 series were prepared in conjunction with this investigation. The units that were described in the atlases were the San Jose, Nacimiento, and Animas Formations; Ojo Alamo Sandstone; Kirtland Shale and Fruitland Formation; Pictured Cliffs Sandstone; Cliff House Sandstone; Menefee Formation; Point Lookout Sandstone; Gallup Sandstone; Dakota Sandstone; and Morrison Formation. Additional descriptions of the alluvial and landslide deposits, Chuska and Crevasse Canyon Sandstones, Lewis and Mancos Shales, Wanakah Formation, and Entrada Sandstone are included in this report. Much of the information in the HA-720 series was generated from digital computer data bases that were directly usable by the computer for compilation of input data for the model. In essence, the major components of the ground-water-flow model were described and documented in the series of hydrologic atlases.

The primary finding resulting from the ground-water-flow simulation was that boundary conditions and internal geometry of the aquifers are the major controls of steady-state groundwater flow and hydraulic heads in the San Juan Basin. Another significant finding was that the computed steady-state ground-water flux is a very minor component (about 1 percent) of the total water budget of the basin.

\section{INTRODUCTION}

This report is one in a series resulting from the U.S. Geological Survey's Regional AquiferSystem Analysis (RASA) program (Sun, 1986). The program began in 1978 with a study of the Northern Great Plains Basin (fig. 1) and has expanded to include 28 regional aquifer systems nationwide that have been or were planned to be investigated.

The study of the San Juan structural basin began in October 1984. Although the San Juan Basin geologically is a part of the Colorado Plateau and is partly in the Colorado River drainage, which defined the area of a preceding RASA, it was excluded from that study because the groundwater-flow system in the San Juan Basin remains regional in scale and is a classical example of an artesian ground-water-flow system. The isolation of the San Juan Basin as a separate investigation within the Colorado Plateau thus provided the opportunity to derive and focus on information that could be compared with other classical artesian basins. 

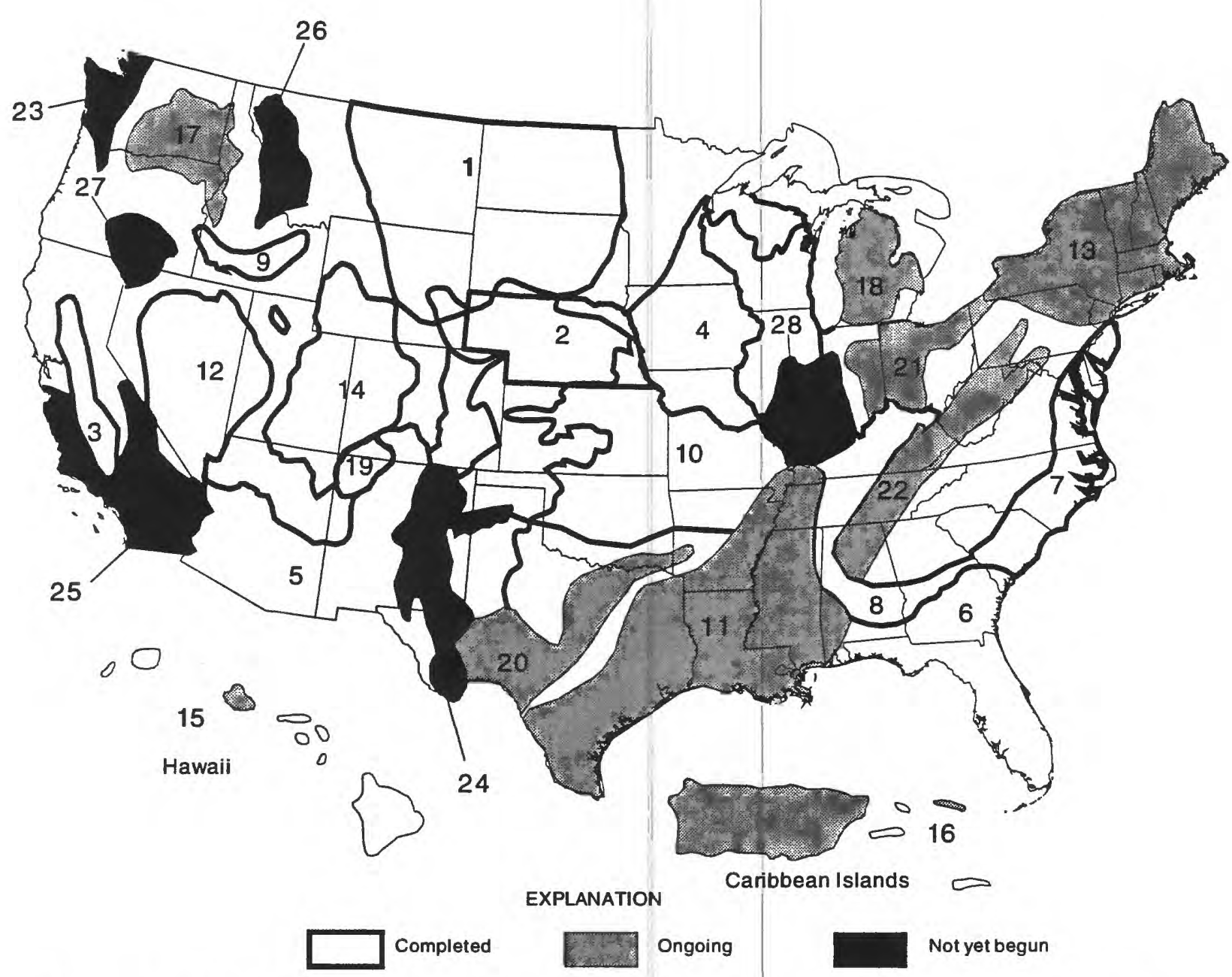

1. Northern Great Plains

2. High Plains

3. Central Valley California

4. Northern Mldwest

5. Southwest alluvial basins

6 . Floridian aquifer

7. Northern Atlantic Coastal Plain

8. Southeastern Coastal Plain

9. Snake River Plain

10. Central Midwest
11. Gulf Coastal Plain

12. Great Basin

13. Northeast glacial valleys

14. Upper Colorado River Basin

15. Oahu Island, Hawaii

16. Caribbean Islands

17. Columbia Plateau

18. Michigan Basin

19. San Juan Basin

20. Edwards-Trinity aquifer
Not yet begun

21. Ohio/Indiana carbonates and glacial deposits

22. Appalachian Valleys and Piedmont

23. Puget-Willamette Trough

24. Pecos River Basin

25. Southern California alluvial basins

26. Northern Rockies Intermontane Basin

27. Alluvial basins, Oregon, Calif., Nev.

28. Illinois Basin

Figure 1.--Location of the Regional Aquifer-System Analysis areas of investigation. 


\section{Purpose and Scope}

The purposes of the San Juan Basin RASA (Welder, 1986) are to: (1) define and characterize the aquifer system; (2) assess the effects of past, present, and potential ground-water use on aquifers and streams; and (3) determine the availability and quality of ground water. These broad objectives were reduced to four specific tasks: (1) the geologic framework was described; (2) the geochemical processes in a selected part of the flow system were investigated and described; (3) the flow system was simulated and described (this report); and (4) a summary of the investigation was prepared. This report describes the geohydrology and presents the results of three-dimensional steady-state ground-water-flow simulations of the major aquifers in the San Juan Basin.

Information on the major water-yielding units in the basin presented in the Hydrologic Investigations Atlas 720 Series and additional unpublished information on non-water-yielding units and minor aquifers were used to describe the geohydrology of the basin and to construct the ground-water-flow model. Existing literature and well-completion records provided information on aquifer properties, water levels, potentiometric heads, and well yields. The completed model was used to give an integrated description of the aquifer-system components and their relation to and interaction with surface recharge and discharge.

\section{Description of the Study Area}

The San Juan structural basin is located in New Mexico, Colorado, Arizona, and Utah, and has an area of about 21,600 square miles (fig. 2). The structural basin is about 140 miles wide and about 200 miles long. The study area is that part of the structural basin that contains rocks of Triassic and younger age; therefore, the study area is less extensive than the structural basin. Triassic through Tertiary sedimentary rocks are emphasized in this study because these units are the major aquifers in the basin. The study area is about 140 miles wide (about the same as the structural basin), 180 miles long, and has an area of about 19,380 square miles. The study area represents 15,550 square miles in New Mexico, 3,100 square miles in Colorado, 720 square miles in Arizona, and 11 square miles in Utah.

Land-surface altitudes in the study area range from about 4,500 feet above sea level in southeastern Utah to about 11,300 feet in the southeastern part of the basin. The area-weighted mean altitude is about 6,700 feet. Annual precipitation in the high mountainous areas along the north and east margins of the basin is as much as 40 inches, whereas annual precipitation in the lower altitude central basin is generally less than 8 inches. Mean annual area-weighted precipitation in the study area is about 12 inches.

\section{Population and Economy}

Data obtained from documents published by the U.S. Bureau of the Census (1980 and 1985) were used to calculate the population of the study area. The population in 1970 was calculated to be about 134,000 . The population increased to about 194,000 in $1980,212,000$ in $1982,221,000$ in 1984, and then decreased to about 210,000 in 1985 . The economy of the basin is supported by exploration for and development of natural gas, petroleum, coal, and uranium resources; urban enterprise; farming and ranching; tourism; and recreation. The rise and fall in population were related to changes in the economic strength of the minerals, oil, and gas industries and support services. Uranium-mining and -milling activities underwent rapid growth from the 1950's until the late 1970's and early 1980's when most uranium-mining activity came to an abrupt end. Likewise, the oil and gas industry prospered until about 1983 and then declined rapidly. 


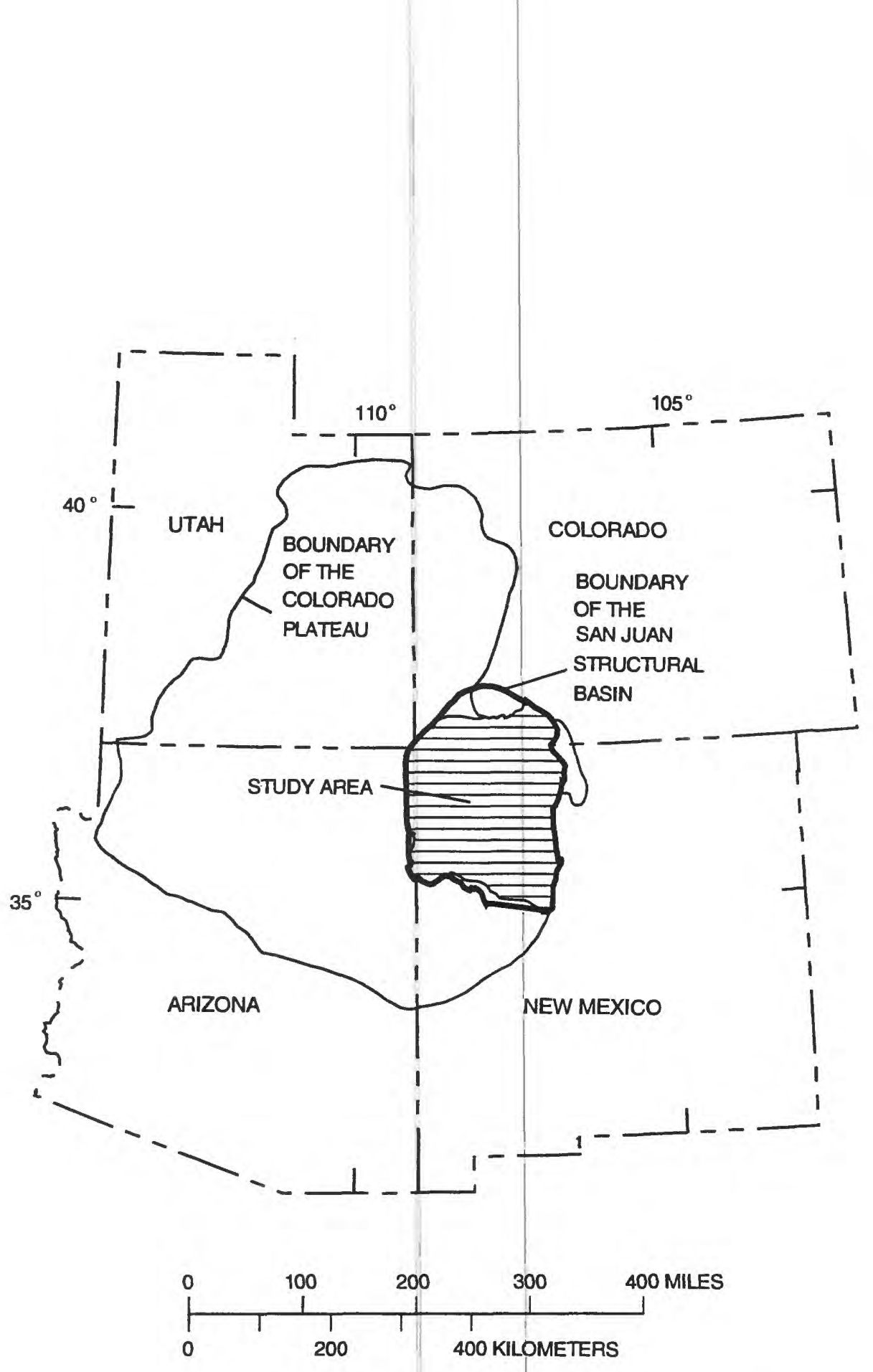

Figure 2.--Location of Colorado Plateau, San Juan structural basin, and study area. 
Population density governs the amount of water that is required for private-domestic or municipal supplies. Population density also reflects the distribution or concentration of commercial and industrial facilities that also have water needs. Ranges in estimated population density in the San Juan Basin for 1985 are shown in figure 3.

\section{Previous Investigations}

Wright (1979) prepared a bibliographic reference for papers and reports that pertain to geologic and geohydrologic subjects for the San Juan Basin. Her publication listed more than 2,500 manuscripts, including many private consultants' reports. Many other hydrogeologic documents have been published since the release of her compilation, including the citations listed in the next paragraph. In addition, a vast number of archeological, climatic, paleoclimatic, and surface-water reports have information relevant to a study of the ground-water basin.

Stone and others (1983) compiled a fairly comprehensive summary of the hydrogeology of the New Mexico part of the San Juan Basin. That report describes the geohydrologic properties of the Wanakah Formation (later terminology) and younger hydrostratigraphic units. Frenzel (1982) completed a three-dimensional steady-state ground-water-flow model of the San Juan Basin in New Mexico and Colorado. Later (1983), he prepared an uncalibrated transient version of the model to investigate possible effects related to proposed development of Federal coal leases. Other models prepared by the U.S. Geological Survey include those by Hearne (1977) and McLean (1980) of aquifers in the vicinity of Gallup, New Mexico. A three-dimensional steadystate model of the Morrison-Dakota-Gallup aquifer subsystem was completed by Kernodle and Philip (1988). One of the most recent models is of the aquifers in Mesozoic rocks in the Four Corners area (Thomas, 1989). Many other reports and papers are cited in the following sections.

\section{Reports Related to the Investigation}

Sun (1986) compiled a summary of RASA investigations. That summary contains detailed information on the overall purpose of the RASA program and the scope and status of the individual investigations, including the San Juan Basin RASA.

A series of Hydrologic Atlases was published in conjunction with this investigation that describe the hydrology, geology, and geochemistry of the major water-yielding hydrostratigraphic units in the study area. Reports in this series describe the hydrogeology of the Dakota Sandstone (Craigg and others, 1989); Gallup Sandstone (Kernodle and others, 1989); Point Lookout Sandstone (Craigg and others, 1990); Morrison Formation (Dam and others, 1990a); Pictured Cliffs Sandstone (Dam and others, 1990b); Kirtland Shale and Fruitland Formation (Kernodle and others, 1990); Menefee Formation (Levings and others, 1990a); San Jose, Nacimiento, and Animas Formations (Levings and others, 1990b); Cliff House Sandstone (Thorn and others, 1990a); and Ojo Alamo Sandstone (Thorn and others, 1990b) in the San Juan structural basin.

The series of atlases was intended to provide information upon which subsequent investigative reports such as this could rely for basic reference material. This report describes a three-dimensional ground-water-flow model of Jurassic and younger hydrostratigraphic units. Levings and others (1996) provided a coherent overview of the multidisciplinary facets of the investigation. The hydrogeochemistry of the Morrison, Dakota, and Gallup aquifers in the northwestern part of the basin was described by Dam (1995). Craigg (in press) describes the geologic framework of the San Juan Basin. 


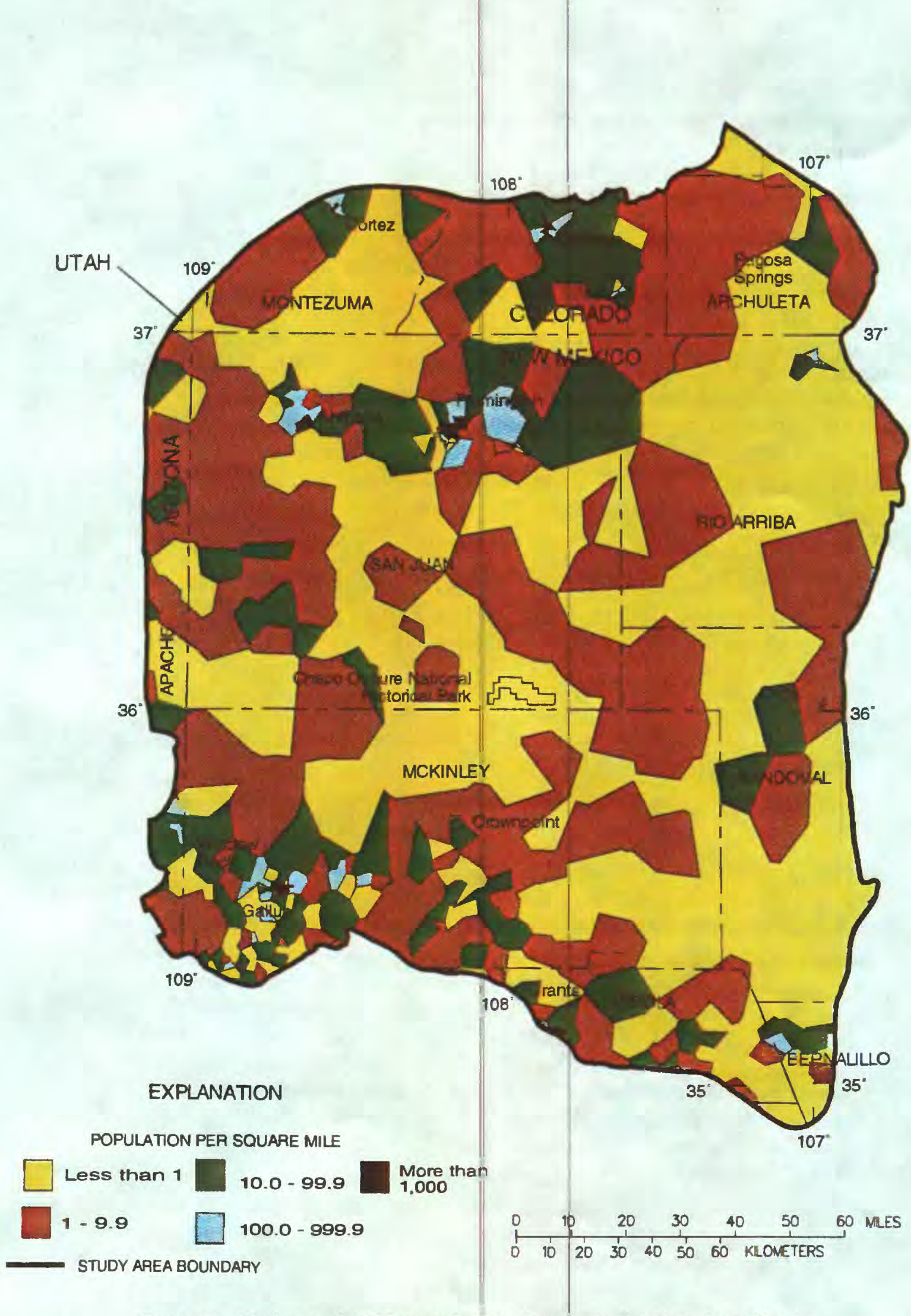

Figure 3.--Estimated 1985 population density in the San Juan Basin (from U.S. Bureau of the Census, 1980 and 1985). 


\section{GEOHYDROLOGIC SETTING}

\section{Geology}

The San Juan structural basin (fig. 4), formed during the Laramide Orogeny (Late Cretaceous-early Tertiary), is an asymmetric syncline that deepens to the northeast. The limits of the basin generally are clearly delineated by faults, uplifts, or monoclines. The clearest example of a fault determining the basin boundary is along the eastern side of the basin where Precambrian granite has been uplifted east of the Nacimiento Fault. The Defiance and Nutria Monoclines also are good examples of basin-bounding features. In some areas, however, the boundary is indistinct and the basin merges across structural saddles with adjacent basins or embayments. Examples of this indistinct boundary between basins are found in the Gallup and Acoma Sags and the Four Corners Platform.

The San Juan structural basin contains a thick sequence of sedimentary rocks ranging in age from Cambrian through Tertiary (fig. 5), but principally from Pennsylvanian through Tertiary. The maximum thickness of the sequence of rocks is about 14,000 feet (Fassett and Hinds, 1971, p. 4). These sedimentary rocks dip basinward from the basin margins toward the troughlike structural center (deepest part of the basin) except where locally interrupted by intrabasinal folds, faults, and domes. Older sedimentary rocks crop out around the basin margins and are successively overlain by younger rocks toward the center of the structural basin (fig. 6). Volcanic rocks of Tertiary age and various deposits of Quaternary age also are present in the basin.

Faulting is common, especially around the northeastern, eastern, and southeastern perimeter of the basin (fig. 7). Faults along the northeastern and eastern perimeter generally are on the platform areas outside the Hogback Monocline. Displacement along these faults is as much as several hundred feet, and along Nacimiento Fault is several thousand feet. Displacement along individual faults in the Puerco Fault Zone in the southeastern part of the basin typically ranges from several tens to a few hundred feet. The basinward side of faults is usually the downthrown side in the Puerco Fault Zone. Fault orientation and displacement in the Crownpoint-Grants, New Mexico, area (also known as the Grants uranium belt) are more disheveled than elsewhere, often leading to some remarkable structures as in the area just south of Crownpoint. When fault displacement and synclinal structure are combined, the maximum structural relief in the basin is about 10,000 feet (Kelley, 1951, p. 126). The present structural elements of the basin largely had developed by middle Tertiary time (Kelley, 1951, p. 130). 


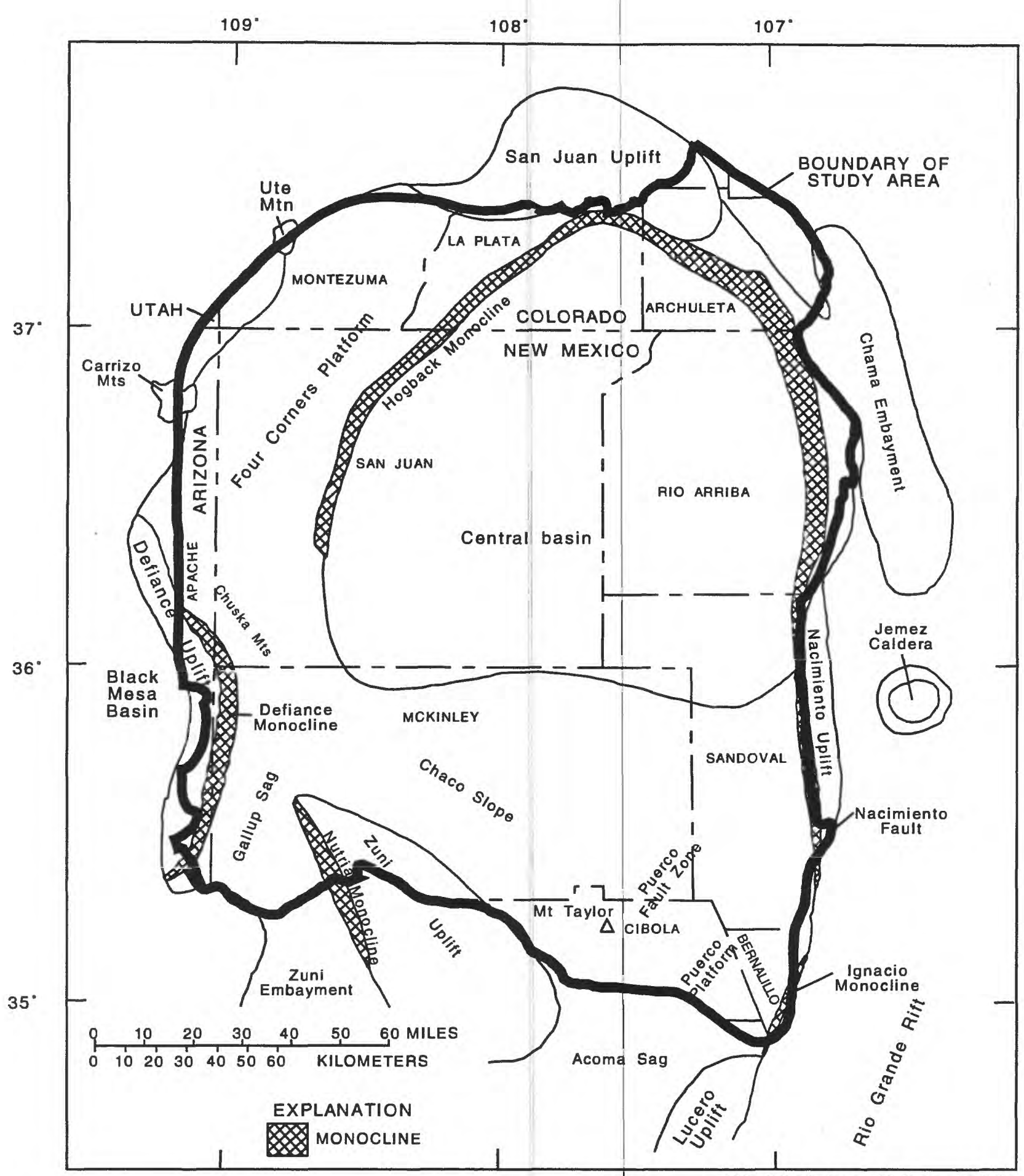

(Modified from Kelley, 1951)

Figure 4.--Structural elements of the San Juan Basin and adjacent areas. 


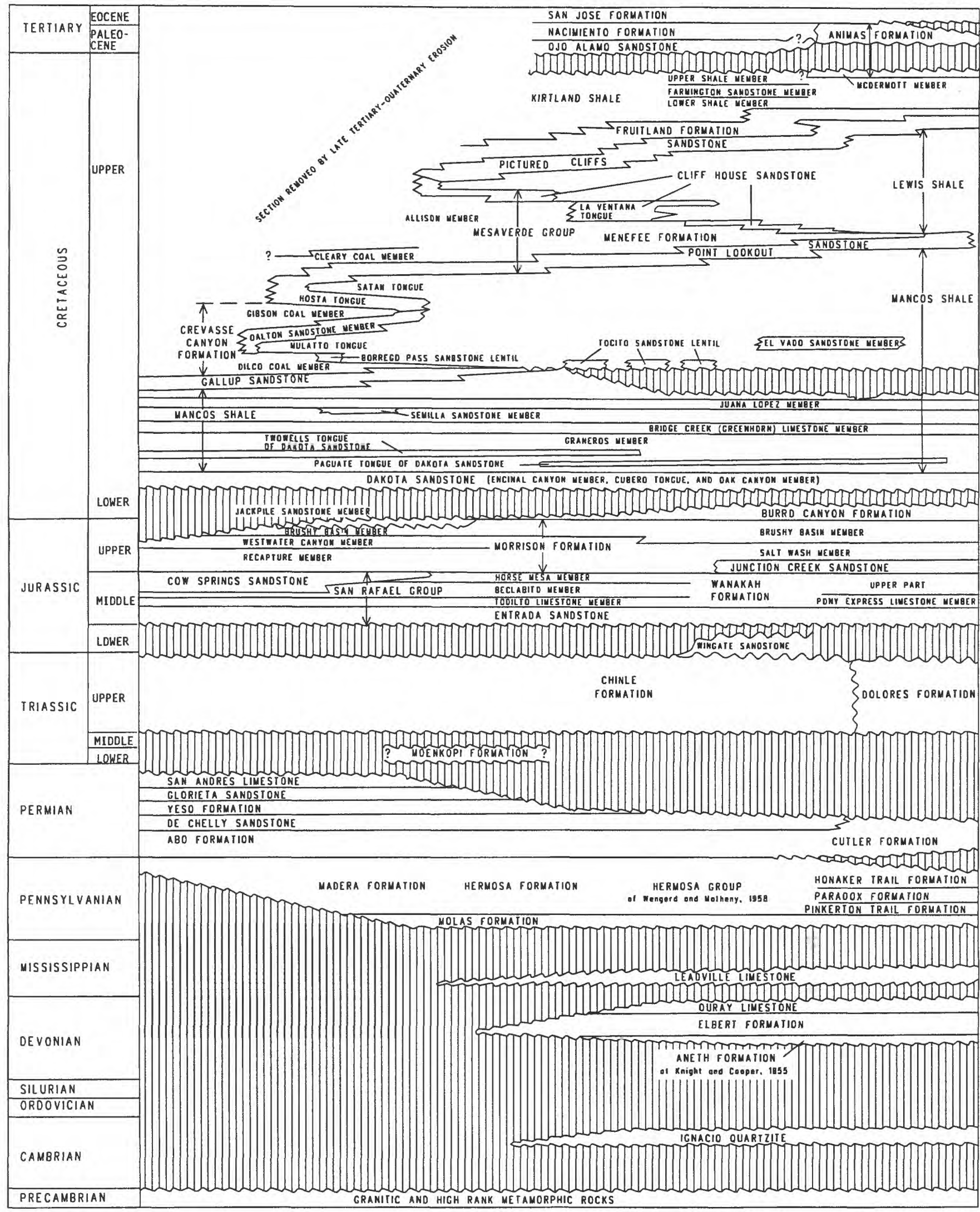

(Modified from Molenaor, 1977a,b, and 1989)

Figure 5.--Time- and rock-stratigraphic framework and nomenclature. 


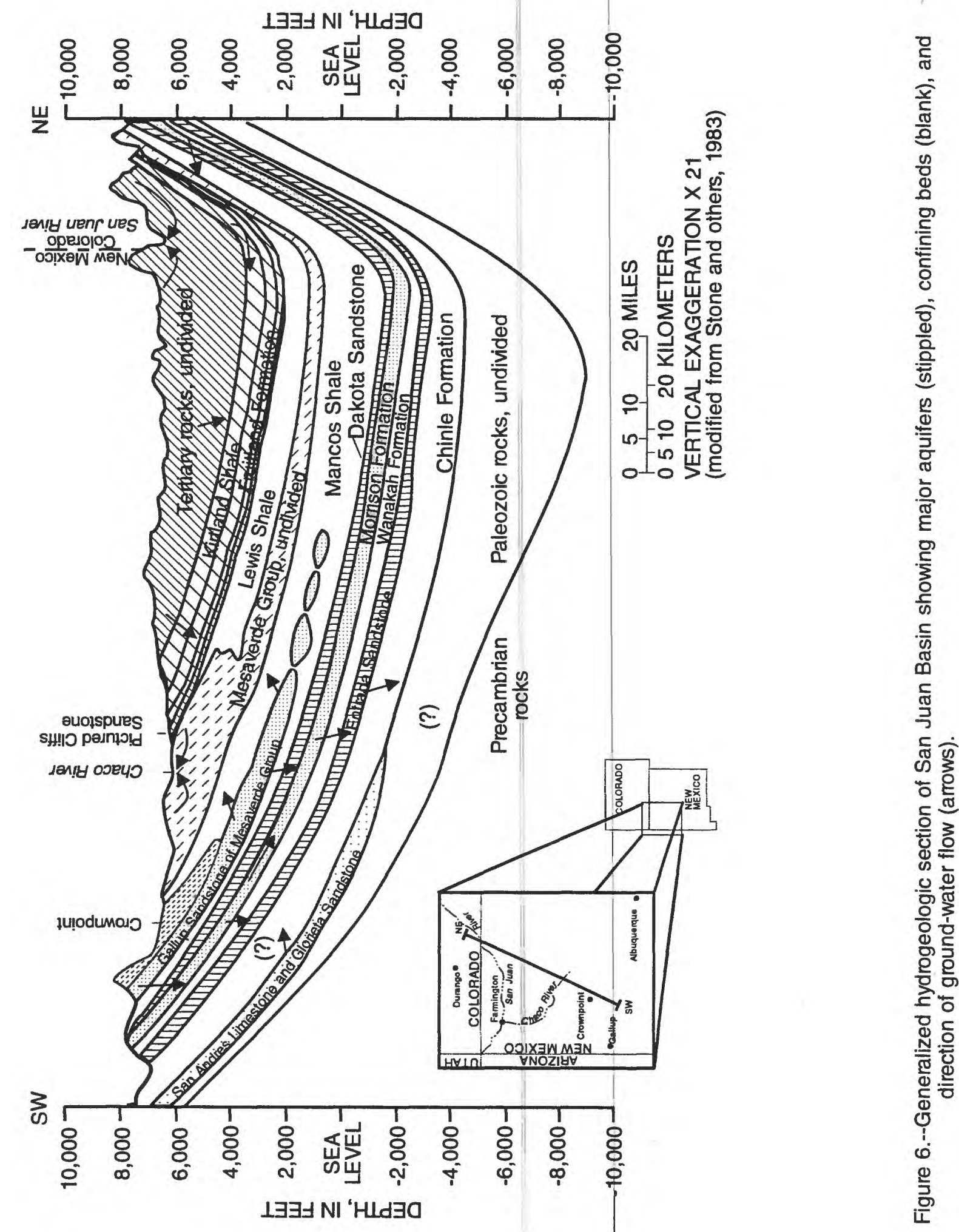




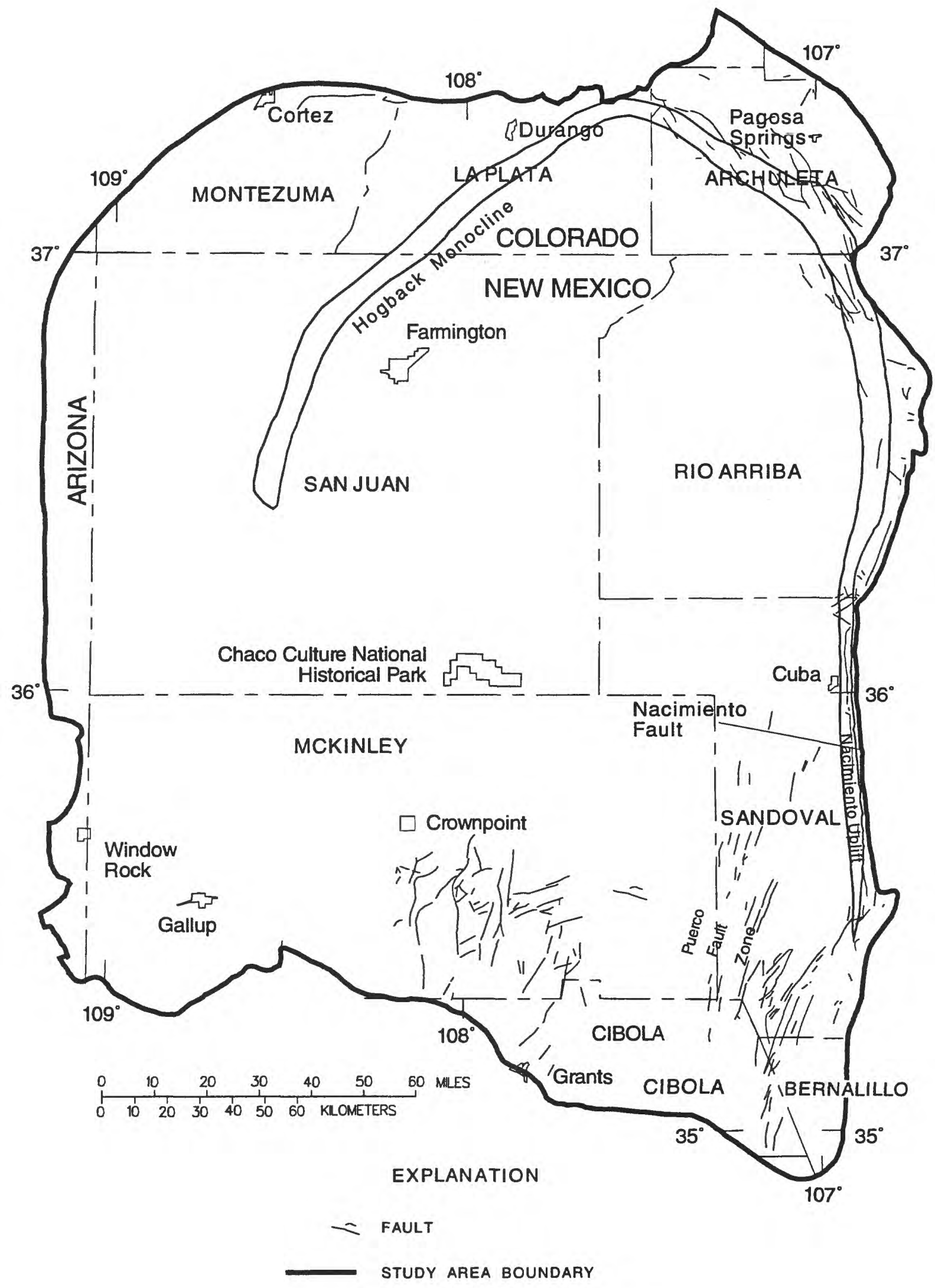

Figure 7.--Major faults in the San Juan Basin. 


\section{Climate}

The San Juan Basin is located in the arid Southwestern United States and therefore typically has mild winters with periodic cold-front storms; hot, dry, and windy springs and early summers; warm and monsoonal late summers; and cool, clear autumns. However, within the San Juan Basin a wide range of climatic conditions are determined primarily by topographic altitude and somewhat by slope aspect. The low-altitude central and northwestern part of the basin has the warmest temperatures and the least amount of precipitation (upper Sonoran climate). The mountainous regions around most of the northern and eastern perimeter of the basin have the coolest temperatures and receive the most precipitation (Canadian climate zone).

Figures 8 and 9 are maps of mean annual and mean winter precipitation for the period 1931-60. As stated earlier, amounts of annual precipitation range from almost 40 inches in the northeastern part of the study area to less than 8 inches in the lower altitude central basin (U.S. Department of Commerce, no date). Most winter precipitation occurs as snowfall, especially in the higher mountain areas where snowpack typically exceeds 100 inches. Spring runoff from melting mountain snowpacks accounts for most surface water in the basin. Convective summer thunderstorms locally may result in considerable amounts of water in a very brief period, often causing severe and dangerous flash floods.

Potential mean annual evaporation (fig. 10) ranges from a low of less than 40 inches in the northeastern to more than 60 inches in the northwestern part of the study area (National Oceanic and Atmospheric Administration, no date). In only a very small part of the study area does annual precipitation exceed potential evaporation, and throughout most of the area potential evaporation greatly exceeds precipitation. With additional losses due to transpiration, the potential annual water deficit is large throughout most of the area. Because of the timing of rain and snowfall, however, water periodically is available for runoff and ground-water recharge regardless of the annual potential deficit. 


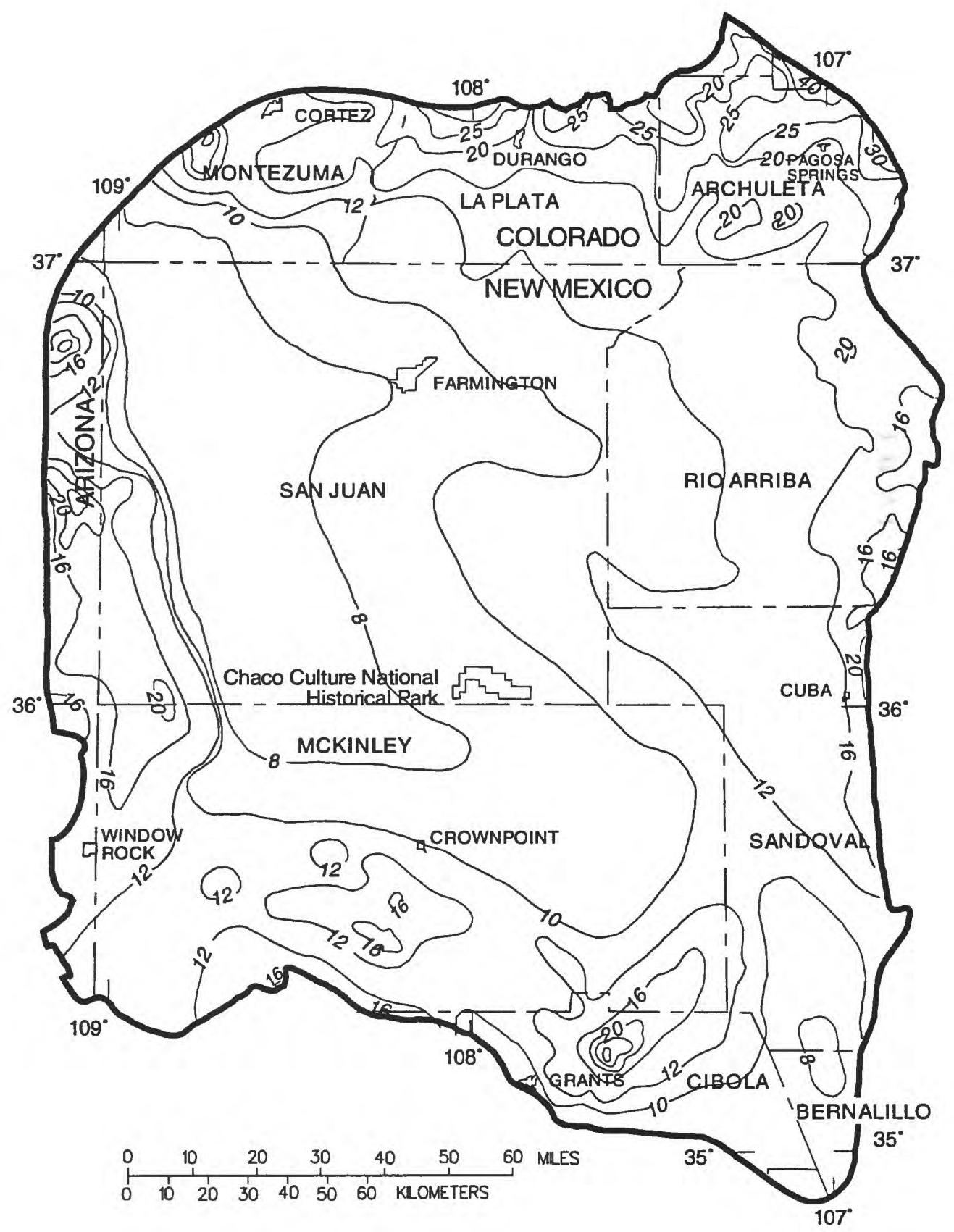

\section{EXPLANATION}

LINE OF EQUal mean anNual

PRECIPITATION--Number indicates mean

annual precipitation, in inches.

Contour intervals 2,4 , and 5 inches

STUDY AREA BOUNDARY

Figure 8.--Mean annual precipitation for the period 1931-60 (from U.S. Department of Commerce, no date). 


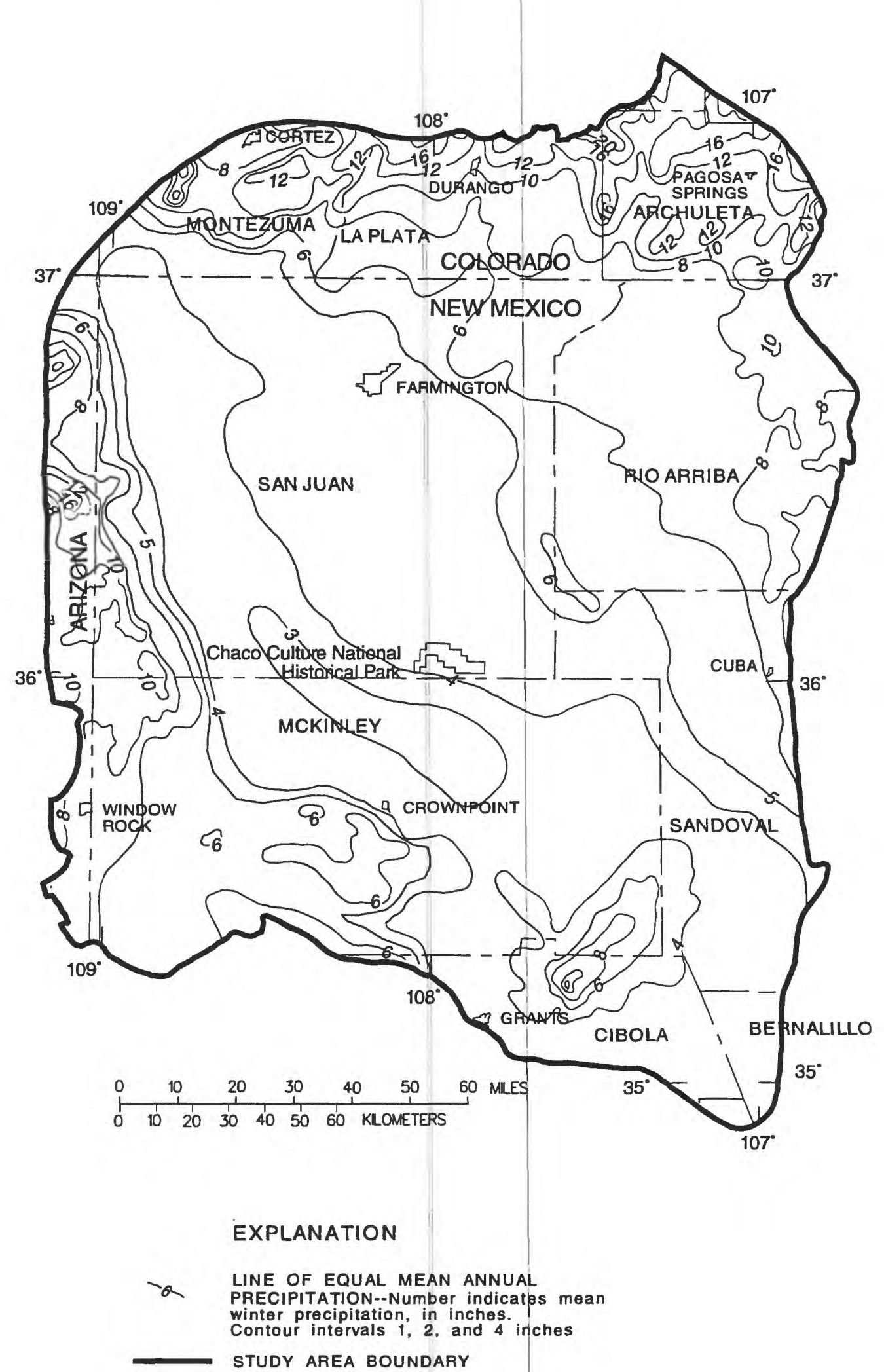

Figure 9.--Mean winter precipitation for the period 1931-60 (from U.S. Department of Commerce, no date). 


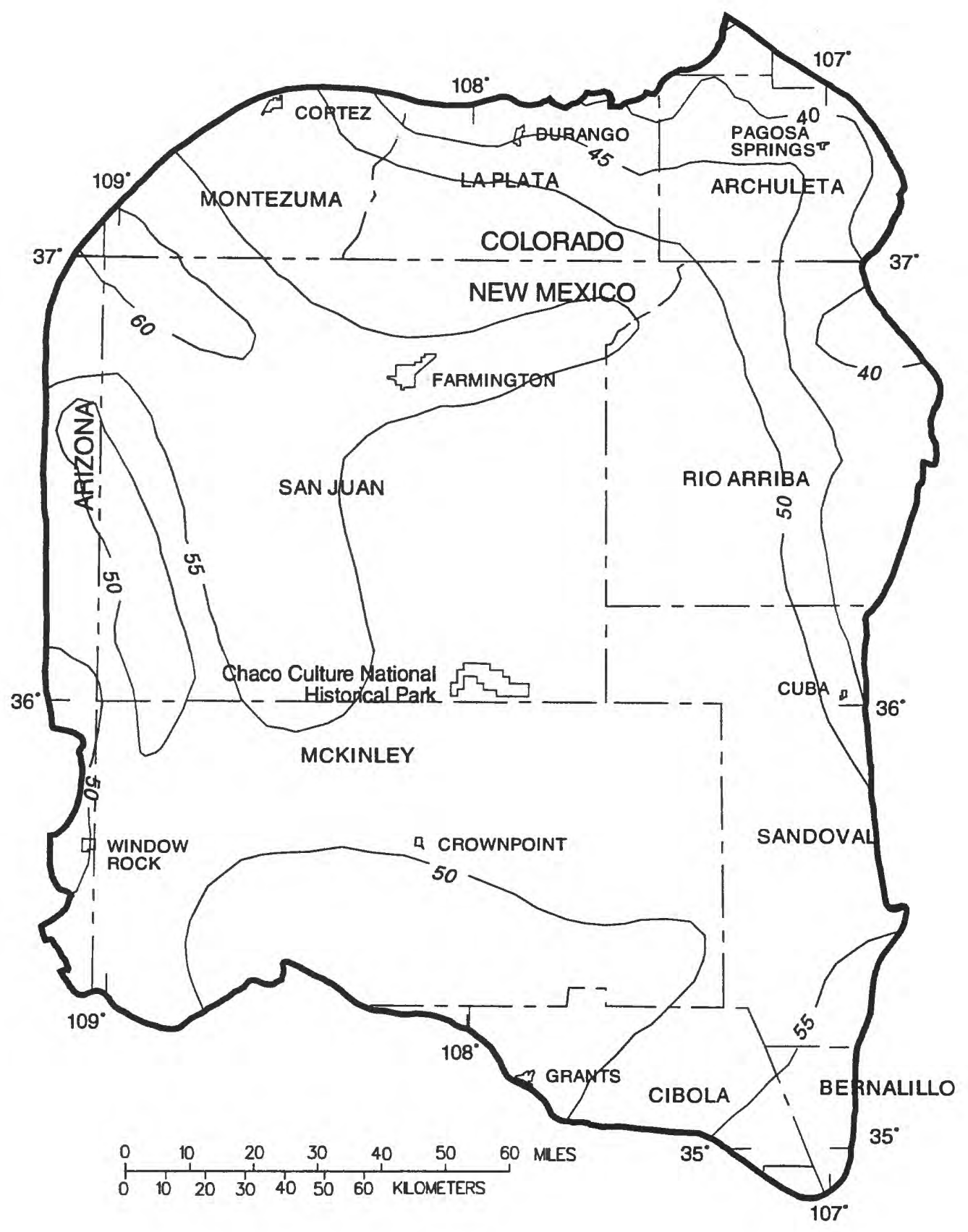

\section{EXPLANATION}

So- LINE OF EQUAL POTENTIAL MEAN ANNUAL

EVAPORATION--Number indicates potential evaporation, in inches per year. Contour interval 5 inches

STUDY AREA BOUNDARY

Figure 10.--Potential mean annual evaporation (from National Oceanic and Atmospheric Administration, no date). 


\section{Surface Water}

The study area is drained mainly by the San Juan River and its tributaries (fig. 11). The San Juan River is a tributary to the Colorado River. The Puerco River and its tributaries in the southwestern part of the study area are also part of the Colorado River system. East of the Continental Divide the Rio Chama, Rio Salado, Rio Puerco, and Rio San Jose drain to the Rio Grande. A diversion from the headwaters of the San Juan River transfers about 100,000 acre-feet of water per year to the headwaters of the Rio Chama.

Only the San Juan River and its major northern tributaries are naturally perennial in the study area. Portions of some streams are perennial for short reaches downstream from spring or well discharges or discharges of treated municipal wastewater. Other streams are ephemeral or seasonal and many only flow immediately after storms.

Several large reservoirs are in the study area. The largest of these, Navajo Reservoir on the San Juan River, is used for irrigation and municipal water supplies. Water stored in or passed through two other reservoirs in the study area, Heron Lake and El Vado Reservoir on the Rio Chama in New Mexico, is allocated for municipal use by the City of Albuquerque, New Mexico, although much of this water is leased from the City for agricultural use downstream from Albuquerque. Bluewater Lake on the Rio San Jose is used to supply water for irrigation. Lemon and Vallecito Reservoirs, in Colorado just outside the study area, provide flood control and supply water for irrigation within the San Juan Basin. All of these reservoirs offer excellent recreational opportunities.

\section{Ground Water}

In a simplified conceptual model of the ground-water-flow system in the San Juan Basin, water enters the ground-water-flow system from precipitation on aquifer outcrops and from stream-channel loss as streams cross the outcrops. Recharge from direct precipitation occurs only after the near-surface demands for moisture are met by the water that does not run off and a residual amount of water is able to reach the zone of saturation in the aquifer. These near-surface demands include evaporation, transpiration, and sublimation.

Once water is in the ground-water-flow system it moves downgradient to areas of natural or artificial discharge, in accordance with Darcy's law (Darcy, 1856) whereby the flow is equal to the ground-water gradient times the aquifer's hydraulic conductivity times the cross-sectional area of the aquifer perpendicular to the direction of flow. Areas of natural discharge include springs and seeps in topographically low parts of the outcrop, discharge from the aquifer outcrop to stream channels, and upward movement across confining units to the surface along fault planes, fractures, and, to a modest extent, along intrusive dikes. Striking examples of spring discharge along fault planes and fractures are at the southern end of the Nacimiento Uplift in the southeastern part of the study area.

Another important mechanism of natural discharge is water moving from one aquifer across a less permeable unit to another aquifer that has relatively lower hydraulic head. Water might also move across a less permeable unit directly to land surface where it would contribute to soil moisture and hence to evaporation or transpiration. Both forms of vertical ground-water movement may be significant in the San Juan Basin. 


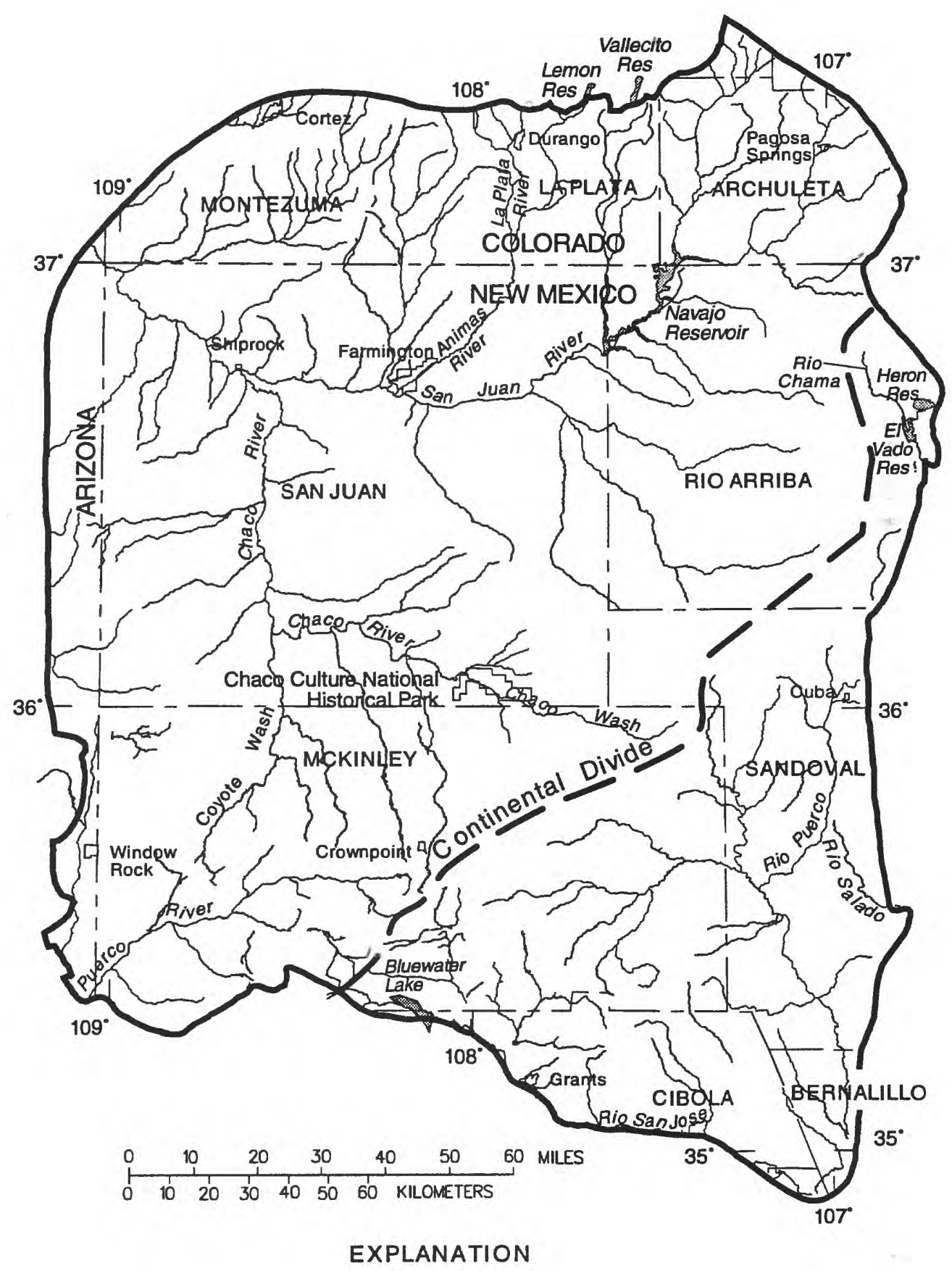

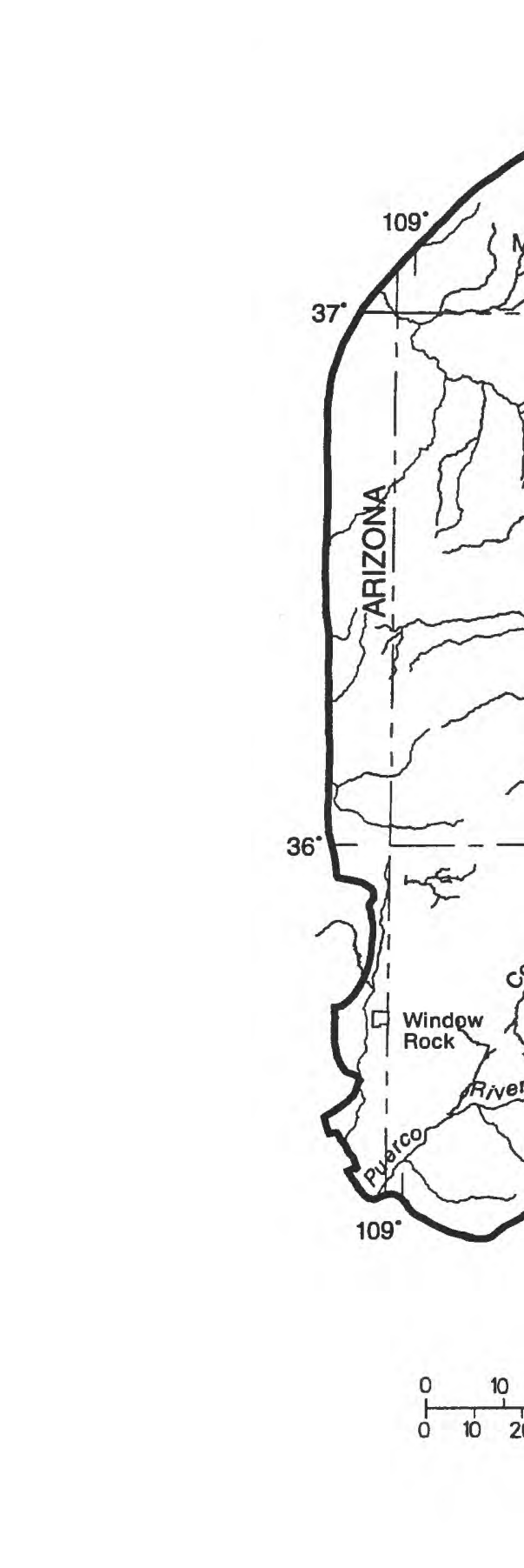

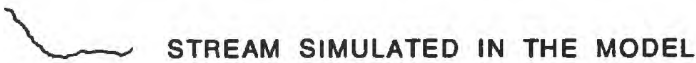

- STUDY AREA BOUNDARY

Figure 11.--Location of streams simulated in the model. 
Artificial discharge occurs at flowing or pumped wells or in conjunction with open-pit or subsurface mining operations. Free-flowing wells are commonplace in the basin and most of those are completed in multiple aquifers so the percentage of water contributed by each aquifer is unknown. Pumped wells or controlled flowing wells also are common and supply water to satisfy municipal, small-community, private-domestic, and livestock needs. The majority of these wells are windmill powered and small yielding, but some yield large quantities of water. Mine dewatering operations have been a major source of ground-water discharge in the south-central part of the basin. Some mines required the removal of as much as 3 cubic feet per second of ground water to keep the mine from flooding. All of the mines presently are closed, the dewatering has ceased, and ground-water levels are now recovering from head reductions that commonly exceeded 1,000 feet.

Complexities in the flow system arise because of non-uniformity in the aquifers. The aquifers may thin or pinch out, or the composition and hydraulic properties may vary in space. Aquifers also may have preferred directions of ground-water flow that are controlled by the orientation of fracture systems or by a persistent orientation of the aquifer's matrix of sedimentary materials. Other pore-filling liquids or gases may create barriers to the movement of water, or water in parts of an aquifer may be saline enough to create a density barrier to movement of freshwater. All of these conditions are present to some degree in the San Juan Basin.

\section{HYDROSTRATIGRAPHIC UNITS}

The San Juan Basin has many hydrostratigraphic units that function either as aquifers or confining units. Other units, such as thin alluvial deposits, may not be hydrologically extensive enough to be classified as major aquifers but potentially are very important in the role they serve in capturing precipitation that eventually becomes recharge to underlying units. Much of the following description of the major hydrostratigraphic units in the San Juan Basin was taken directly from U.S. Geological Survey Hydrologic Investigations Atlases in the HA-720 series (Craigg and others, 1989, 1990; Dam and others, 1990a, b; Kernodle and others, 1989, 1990; Levings and others, 1990a, b; and Thorn and others, 1990a, b).

The structure-contour maps presented in this section are derived from computer-generated and human-edited continuous-surface representations of the tops of the major hydrostratigraphic units. These continuous-surface data layers were generated from the control points shown in the HA-720 series of Hydrologic Investigations Atlases and geographic information system (GIS)generated outcrop altitudes. The representations were imported into the GIS, which was then used to produce the figures in the atlases and in this report. Much of the information in those atlases also was used directly by the computer for compilation of input data for the model, as described later. In essence, the major components of the ground-water-flow model were documented in the series of hydrologic atlases. In the following section the hydrostratigraphic units are discussed in order of uppermost (youngest) to lowermost (oldest) occurrence. 


\section{Alluvium and Other Quaternary Deposits}

Quaternary and recent deposits in the San Juan Basin include stream-deposited alluvium and older terrace deposits, landslide deposits, and eolian sand. The areal distribution of these sediments are shown in figure 12. Most Quaternary and younger deposits are unconsolidated and form a thin covering over older bedrock sediments.

\section{Lithology}

Stream-deposited alluvium and older terrace deposits are associated with major streams and rivers in the San Juan Basin. The alluvium consists of unconsolidated sediments that range from silt to cobbles in size but predominantly are sand and gravel. Along major streams the alluvium is varied in composition, depending on the mix of material from the various erosional source areas. Alluvial deposits also occur as a thin veneer of fine-grained sediments in the valleys of intermittent streams.

Landslide deposits are mapped on the northeastern flank of the Chuska Mountains and locally in the San Juan Mountains in the northeastern part of the study area. These colluvial deposits consist of material derived from the topographically higher source areas. The landslide material on the flank of the Chuska Mountains consists of reworked sand from the Chuska Sandstone; the deposits in the San Juan Mountains primarily are derived from volcanic or volcaniclastic sources.

Unconsolidated wind-blown deposits are common in the central part of the basin, although they generally are not mapped on small-scale geologic maps. Typically, these deposits are very thin, but local dunes near dry washes, which are excellent sources of fine-grained material, may reach heights of 20 feet. These recent eolian deposits are not known to yield water to wells.

\section{Hydraulic Properties}

In the absence of other sources of water, alluvial deposits, where present, commonly are relied upon as a source of water for domestic and livestock use. Along the major rivers and streams, wells are of conventional vertical design, whereas in the valleys of intermittent streams, where the hydraulic conductivities and saturated thickness generally are small, most wells are constructed as galleries of horizontal drains feeding to a central collector. Reported well yields range from less than 1 gallon per minute to as much as 1,100 gallons per minute. The median yield of 48 wells is 15 gallons per minute. The largest reported yields are from wells completed in the alluvium in the Rio San Jose Valley (fig. 11) in the vicinity of Grants, New Mexico. The smaller yields are from gallery wells completed in the alluvium of minor stream valleys.

Hydraulic conductivities of sand and gravel can vary from 10 to $1,000,000$ gallons per day per foot squared (roughly 1 to 100,000 feet per day) (Freeze and Cherry, 1979, table 2.2), but a more typical range is from 15 feet per day for fine sand to about 1,000 feet per day for coarse gravel (Lohman, 1972, table 17). Tests along the San Juan River (fig. 11) upstream from Farmington indicate that the hydraulic conductivity of alluvium ranges from 0.006 to 220 feet per day (Peter and others, 1987, p. 29). The thickness of alluvium at this site was reported to range from about 14 to 61 feet, and the saturated thickness was less than 25 feet in all 13 test holes. Water occurs in the alluvium under unconfined conditions. No tests have been made where the storage coefficient of the alluvium was determined. However, a typical specific yield for moderately to well-sorted unconsolidated sediments would be in the range of 0.1 to 0.25 .

No known hydraulic data exist for the landslide and recent eolian deposits in the basin. No instances are known where these deposits are used as a source of water. 


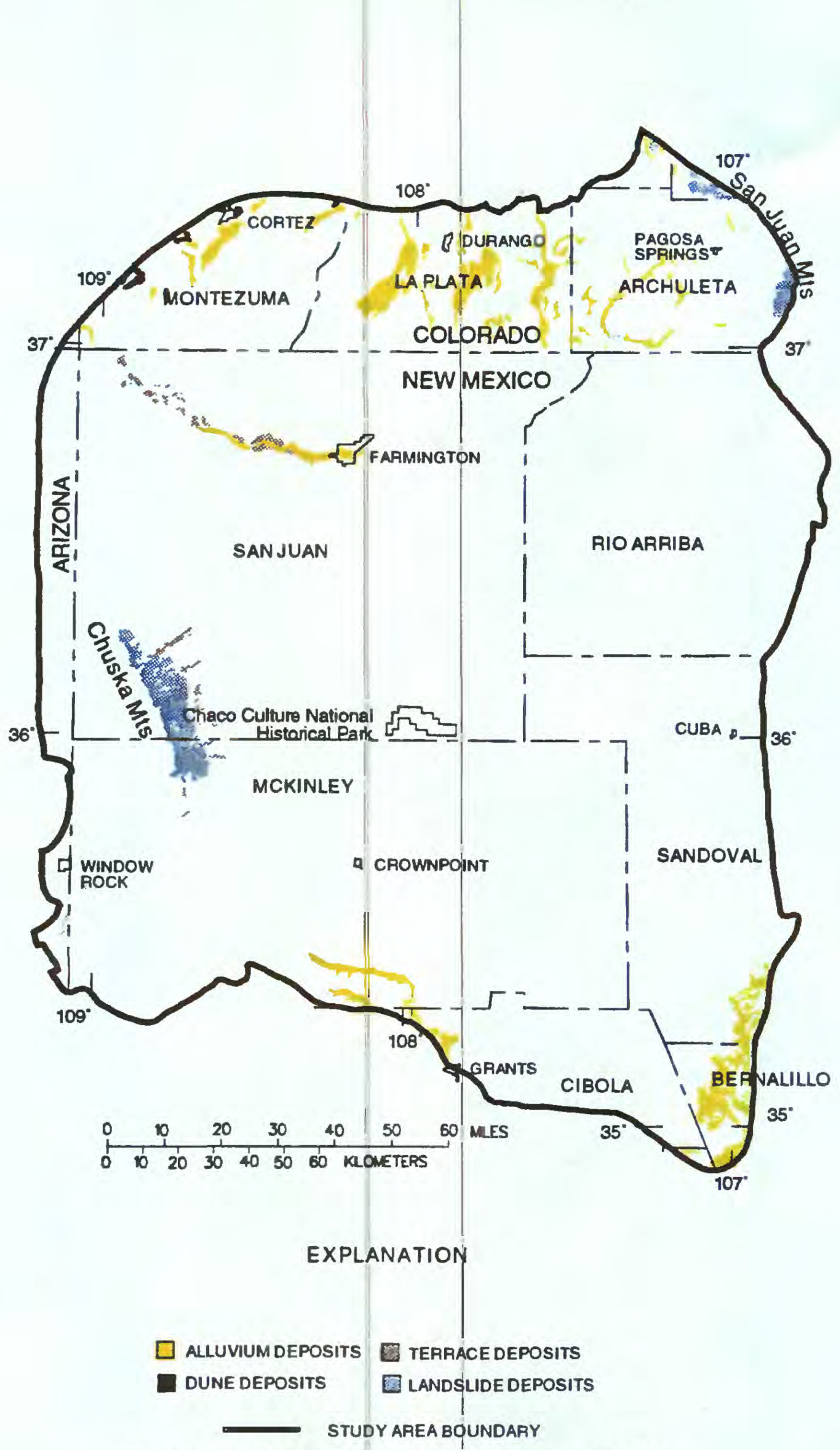

Figure 12..-Distribution of Quaternary deposits. 


\section{Chuska Sandstone}

The Chuska Mountains (fig. 12) in the western part of the basin primarily are formed from the Chuska Sandstone, a consolidated, windblown sand of Tertiary age that was deposited on upturned and eroded Cretaceous and older sediments. Several moderate-sized intrusive mafic necks form a spine along the ridge of the mountains and, together with associated horizontal lava flows, may have provided the erosional resistance necessary to protect the sandstone from weathering away, as has happened toward its source area to the south-southwest.

\section{Lithology}

The Chuska Sandstone is a fine-grained, moderately well sorted sandstone (Harshbarger and Repenning, 1954, p. 6). Cross-bed units typically range from 5 to 15 feet in thickness. Thick zones of silicic cement form resistant ledges at and near the top of the unit, but overall the sandstone is weakly cemented. Cementation is more complete to the southwest, allowing conventional headward erosion of streams. The poorly cemented sand on the northeastern flank of the Chuska Mountains has allowed piping and massive slump failure during pluvial periods in the Pleistocene Epoch. The average thickness of the Chuska Sandstone is about 1,000 feet and the maximum preserved thickness is 1,750 feet (Wright, 1956, p. 416). The Chuska Sandstone conformably overlies a horizontally bedded fluvial sandstone and shale about 250 feet in thickness (the Deza Formation of Wright, 1954).

\section{Hydraulic Properties}

No measurements are known of the hydraulic properties of the Chuska Sandstone. However, the unit is water yielding and springs are abundant around the flanks of the Chuska Mountains, usually at the base of the Chuska Sandstone. Most of the springs are undeveloped, but some serve as domestic water supplies. The sandstone is recharged by leakage from the numerous lakes and potholes along the top of the mountains. In addition to the discharge from springs, the sandstone loses water to the underlying Cretaceous and older sediments.

\section{San Jose Formation}

The San Jose Formation of Eocene age was defined by Simpson (1948a, b). The San Jose Formation occurs in New Mexico and Colorado, and its outcrop forms the land surface over much of the eastern half of the central basin (fig. 4). It overlies the Nacimiento Formation in the area generally south of the Colorado-New Mexico State line and overlies the Animas Formation in the area generally north of the State line (Fassett, 1974, p. 229). The basal contact of the San Jose varies with location in the basin. This contact is a disconformity along the basin margins and an angular unconformity along the Nacimiento Uplift; the contact is conformable in the central basin (Baltz, 1967, p. 54; Fassett, 1974, p. 229).

\section{Geometry and Lithology}

The San Jose Formation was deposited in various fluvial-type environments (Baltz, 1967, p. 44-55). In general, the unit consists of an interbedded sequence of sandstone, siltstone, and variegated shale. The sandstones are buff to yellow and rusty colored, crossbedded, very fine to 
coarse-grained arkose, which are locally conglomeratic and contain abundant silicified wood (Baltz, 1967, p. 46; Fassett, 1974, p. 229; Anderholm, 1979, p. 23).

Baltz (1967, p. 45) recognized four formal members of the San Jose Formation in the eastcentral part of the basin; he also identified, but did not name, a fifth member in the northeastern part of the basin. The members and their principal lithology in descending order are Tapicitos Member (shale), Llaves Member (sandstone), Regina Member (shale), and Cuba Mesa Member (sandstone). The stratigraphic relation and subsequent mapability of these members are complicated by extensive intertonguing and pinch-outs (Fassett, 1974, p. 229; Anderholm, 1979, p. 23; Stone and others, 1983, p. 25), and whether the members can be identified throughout the basin has been the subject of some discussion.

Thickness of the San Jose Formation generally increases from west to east. Fassett (1974, p. 229) reported a maximum thickness of 2,400 feet in the east-central part of the basin, and Stone and others $(1983$, p. 25$)$ reported a range from about 200 feet in the west and south to almost 2,700 feet in the center of the structural basin.

\section{Hydraulic Properties}

Transmissivity data for the San Jose Formation are minimal. Values of 40 and 120 feet squared per day were determined from two aquifer tests (Stone and others, 1983, table 5).

The reported or measured discharge from 46 water wells completed in the San Jose Formation ranges from 0.15 to 61 gallons per minute and the median is 5 gallons per minute. Most of the wells provide water for livestock and domestic use, but a few provide cooling water for natural gas compression and transmission plants.

The San Jose Formation is a very suitable unit for recharge from precipitation because soils that form on the unit are sandy and highly permeable and therefore readily adsorb precipitation. However, low annual precipitation, relatively high transpiration and evaporation rates, and deep dissection of the San Jose Formation by the San Juan River and its tributaries all tend to reduce the effective recharge to the unit.

\section{Animas and Nacimiento Formations}

Most of the Animas Formation is of Paleocene age, but the lower part of the formation is of latest Late Cretaceous age (Barnes and others, 1954). It crops out principally inside the northern margin of the central basin (fig. 4). The Animas is present in only about the northern one-third of the basin, mainly in Colorado; it does not occur south of a line that extends from Dulce, New Mexico, to the La Plata River Valley (fig. 11) near the Colorado-New Mexico State line (fig. 13). Along this line the Animas Formation grades laterally into the Nacimiento Formation (Fassett and Hinds, 1971, p. 33; Fassett, 1974, p. 229), which occupies the same stratigraphic interval (fig. 5). In the north the Animas Formation conformably overlies the Kirtland Shale of Late Cretaceous age; farther south, near the New Mexico-Colorado State line, the unit may unconformably overlie the Ojo Alamo Sandstone of Tertiary age (Fassett and Hinds, 1971, p. 34). 


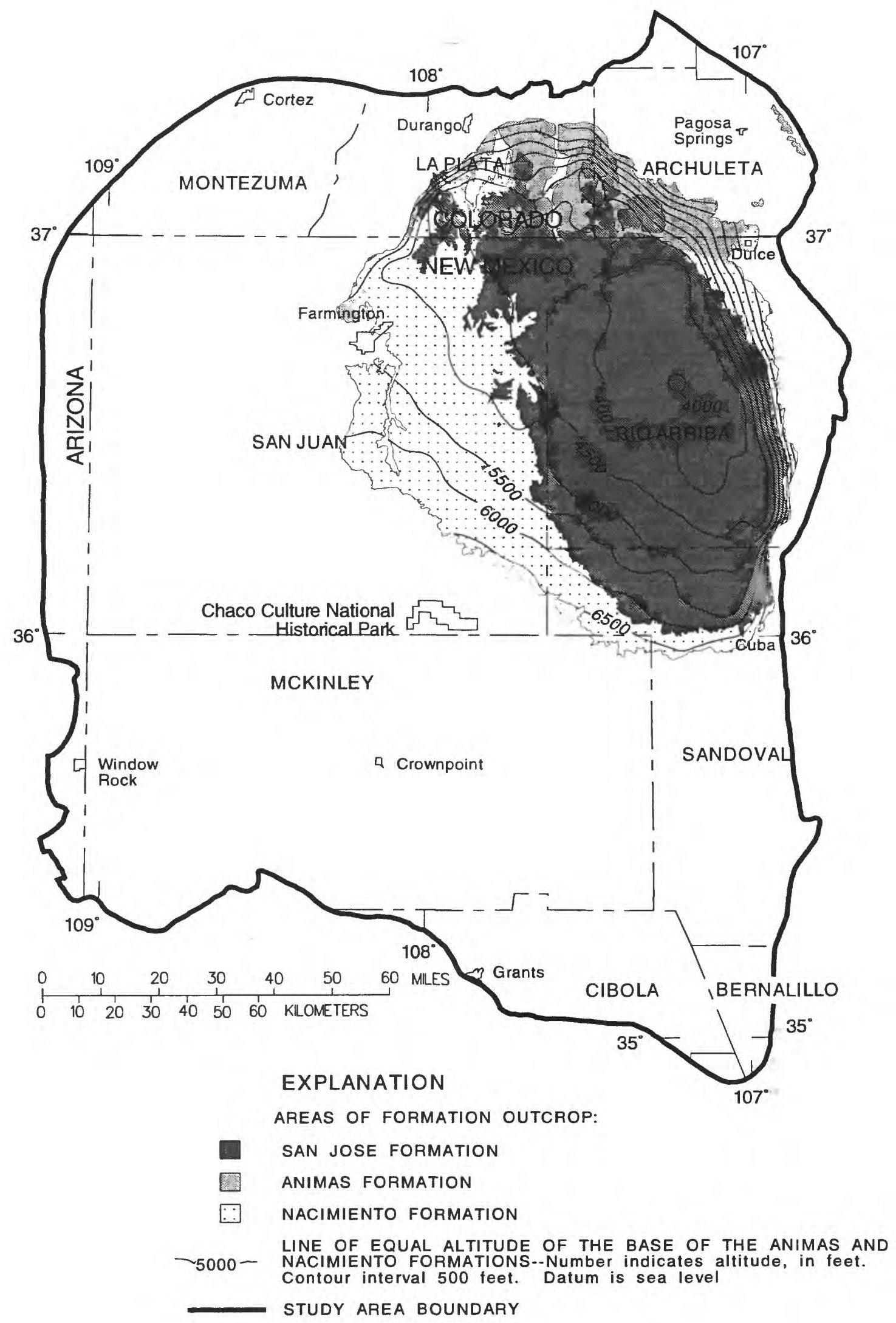

Figure 13.--Approximate altitude and configuration of the base of the Animas and Nacimiento Formations. 


\section{Geometry and Lithology}

The Animas Formation consists of two members: the unnamed upper member of Paleocene age (Barnes and others, 1954) and the lower McDermott Member of latest Late Cretaceous age. The unnamed upper member disconformably overlies the McDermott Member; this unconformity represents a time gap of about 6 million years (Fassett, 1977). The Animas Formation consists mainly of volcaniclastic deposits; the diagnostic characteristic of the Animas Formation as a whole is the presence of macroscopic volcanic material (Fassett and Hinds, 1971, p. 33). The unnamed upper member consists of varicolored and interbedded tuffaceous sandstone, conglomerate, and shale (Fassett, 1974, p. 229). The McDermott Member consists of varicolored (dominantly purple) tuffaceous sandstone and conglomerate with minor variegated shale (Reeside, 1924, p. 25). Thickness of the Animas Formation ranges from about 230 feet at the type section along the Animas River (fig. 11) at Durango, Colorado (Barnes and others, 1954), to about 2,700 feet near the La Plata-Archuleta County line in Colorado (fig. 14) (Fassett and Hinds, 1971, p. 33).

The Nacimiento Formation is of Paleocene age (Baltz, 1967, p. 35). It crops out in a broad band inside the southern and western margins of the central basin and in a narrow band along the west face of the Nacimiento Uplift (fig. 4). The Nacimiento is a nonresistant unit and typically erodes to low, rounded hills or forms badlands topography.

The Nacimiento Formation occurs in approximately only the southern two-thirds of the basin where it conformably overlies and intertongues with the Ojo Alamo Sandstone (Baltz, 1967, p. 41; Fassett, 1974, p. 229). The Nacimiento Formation grades laterally into the main part of the Animas Formation (Fassett and Hinds, 1971, p. 34; Fassett, 1974, p. 229); thus, in this area the two formations occupy the same stratigraphic interval (fig. 5). The altitude of the base of the Animas and Nacimiento Formations is shown in figure 13.

Strata of the Nacimiento Formation mainly were deposited in lakebeds in the central basin area with lesser deposition in stream channels (Brimhall, 1973, p. 201; Fassett, 1974, p. 229). In general, the Nacimiento consists of drab, interbedded black and gray shale with discontinuous, white, medium- to very coarse grained arkosic sandstone (Fassett, 1974, p. 229; Stone and others, 1983 , p. 30). Baltz (1967, p. 39) stated that the percentage of sandstone increases northward. Stone and others $(1983$, p. 30$)$ indicated that the formation may contain more sandstone than commonly has been reported because some investigators assume the slope-forming strata in the unit are shales, whereas in many places the strata actually are poorly consolidated sandstones.

Total thickness of the Nacimiento Formation ranges from about 500 to 1,300 feet (Molenaar, 1977a). The unit generally thickens from the basin margins toward the basin center (Baltz, 1967, p. 38; Steven and others, 1974; Stone and others, 1983). The sandstone deposits within the Nacimiento Formation are much thinner than the total thickness of the formation because their environment of deposition was localized stream channels (Brimhall, 1973, p. 201). The combined thickness of the combined San Jose, Animas, and Nacimiento Formations ranges from 500 to more than 3,500 feet (fig. 14). 


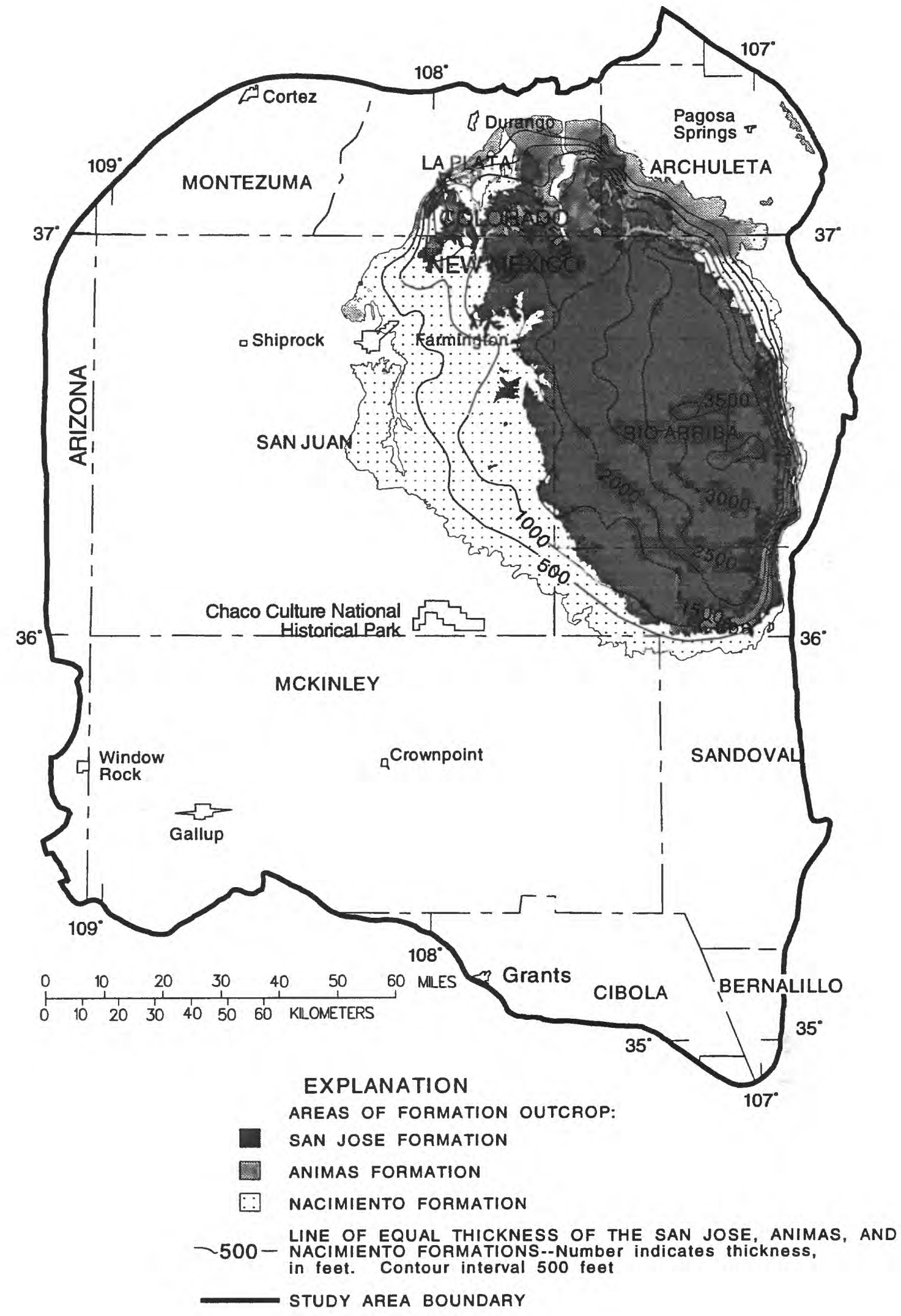

Figure 14.--Approximate thickness of the San Jose, Animas, and Nacimiento Formations. 


\section{Hydraulic Properties}

Reported well yields for 53 wells completed in either the Animas or Nacimiento Formations range from 2 to 90 gallons per minute and the median yield is 7.5 gallons per minute. The primary use of water from the Nacimiento and Animas Formations is domestic and livestock supplies. There are no known aquifer tests for the Animas or Nacimiento Formations, but specific capacities reported for six wells range from 0.24 to 2.30 gallons per minute per foot of drawdown (Levings and others, 1990b).

The Animas and Nacimiento Formations are in many ways hydrologically similar to the San Jose Formation because sands in both units produce approximately the same quantities of water. However, the greater percentage of fine material in the Animas and Nacimiento Formations may restrict downward vertical leakage to the Ojo Alamo Sandstone or Kirtland Shale. The poorly cemented fine material is highly erodible, forms a badlands terrain, and supports only spotty vegetation. These conditions are more conducive to runoff than to retention of precipitation.

\section{Ojo Alamo Sandstone}

The Ojo Alamo Sandstone is of early Tertiary (Paleocene) age. It crops out inside the central basin and typically forms cliffs and dip slopes or caps low mesas and forms rounded hills. The majority of Ojo Alamo rocks are in New Mexico (fig. 15). The unit pinches out in the northwest about halfway between Farmington, New Mexico, and the Colorado State line west of the La Plata River (fig. 11). In the northeast, Ojo Alamo outcrops extend into Colorado, where they pinch out a few miles north of the State line, south of Pagosa Springs, Colorado (Fassett, 1974, p. 228). Subsurface studies by Fassett and Hinds (1971, fig. 9 and p. 29) indicate that the Ojo Alamo is not present north of a line connecting the northernmost limits of the Ojo Alamo outcrops (fig. 15).

The Ojo Alamo Sandstone disconformably overlies the Kirtland Shale throughout most of the basin. On the east side, however, the Kirtland Shale has been removed by pre-Ojo Alamo erosion, and the Ojo Alamo disconformably overlies the Fruitland Formation; locally in places where the Fruitland Formation has been removed, the Ojo Alamo rests directly on the Lewis Shale (Fassett, 1974, p. 228). The contact of the Ojo Alamo with underlying rocks has been described by O'Sullivan and others (1972, p. 56) as "a sharp wavy surface of erosion." Fassett and Hinds (1971, p. 28) reported large-scale channeling at the base of the Ojo Alamo and stated that some of these channels cut 50 feet or more into the underlying shales or sandstones of the Kirtland Shale or Fruitland Formation. The Ojo Alamo is conformably overlain by the Nacimiento Formation throughout most of the basin, and intertonguing at the contact is common (Fassett and Hinds, 1971, p. 29). 


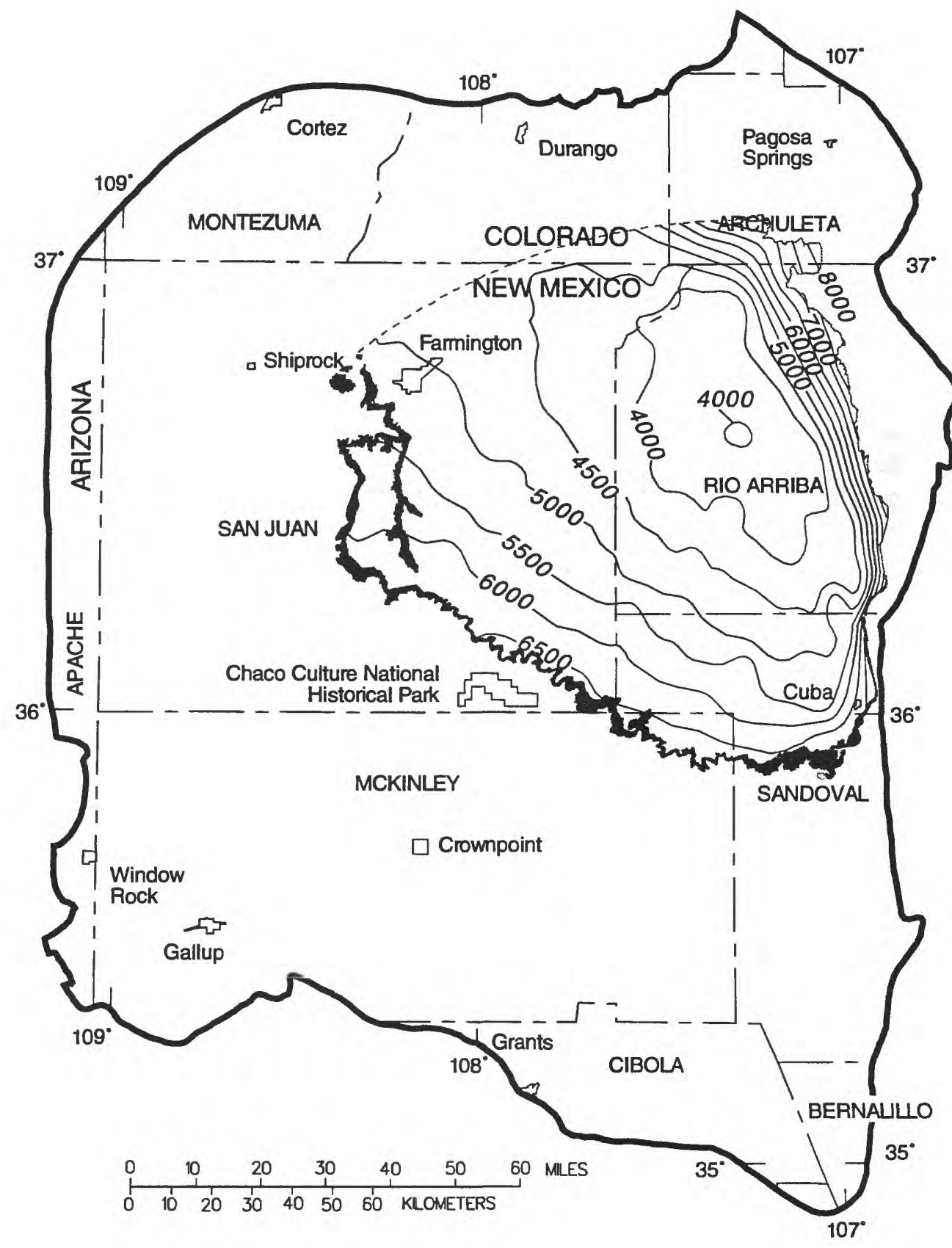

\section{EXPLANATION}

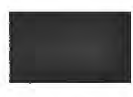

OUTCROP OF OJO ALAMO SANDSTONE

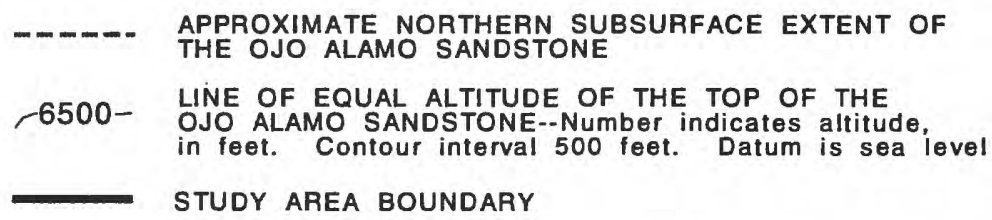

Figure 15.--Approximate altitude and configuration of the top of the Ojo Alamo Sandstone. 


\section{Geometry and Lithology}

In general, the Ojo Alamo Sandstone consists of overlapping sheetlike sequences of conglomeratic sandstones and sandstones, which locally contain interbedded shale lenses. The sandstones are arkosic, light brown to rusty brown, or buff and tan, and contain abundant silicified wood. The sandstones are medium to very coarse grained and often conglomeratic, containing pebbles of various compositions that decrease in size and quantity from west to east across the basin (Baltz and West, 1967, p. 17; Fassett and Hinds, 1971, p. 28).

Thickness of the Ojo Alamo Sandstone is variable. Baltz (1967, p. 32) reported that thickness ranges from 70 feet to a maximum of 200 feet. O'Sullivan and others (1972, p. 57) also reported a maximum thickness of 200 feet. Stone and others $(1983$, p. 31) reported a range of about 70 to 300 feet. In a basinwide study, Fassett and Hinds $(1971$, p. 28, 29) reported that thickness of the Ojo Alamo varies from about 20 to 400 feet but that a range of 50 to 150 feet is most common. Fassett and Hinds (1971, p. 28) stated that thickness varies according to the number of sandstone beds that constitute the unit at any given location.

The altitude of the top of the Ojo Alamo Sandstone is shown in figure 15. The top of the Ojo Alamo decreases from a maximum altitude of about 8,000 feet along the northeastern basin margin to about 4,000 feet in the east-central part of the study area.

\section{Hydraulic Properties}

The transmissivity of the Ojo Alamo Sandstone ranges from 57 to 164 feet squared per day; the median value is 104 feet squared per day for 10 aquifer tests (Brimhall, 1973, p. 206; Anderholm, 1979, p. 29; Stone and others, 1983, table 5). (These data represent wells that are on or near the outcrop and are less than 1,100 feet deep. Data are available for three aquifer tests performed on two test wells more than 4,000 feet deep near the center of the basin; transmissivity for these tests ranges from 0.05 to 0.39 foot squared per day and the median value is 0.35 foot squared per day (Mercer, 1969).

Reported or measured discharges from 19 water wells completed in the Ojo Alamo Sandstone range from 1.2 to 112 gallons per minute, and the median is 12 gallons per minute. The specific capacity of nine of these wells ranges from 0.01 to 2.04 gallons per minute per foot of drawdown and the median is $\mathbf{0 . 2 6}$ gallon per minute per foot of drawdown.

The Ojo Alamo is resistant to erosion, and the outcrop generally forms a prominent ridge or cliff or caps mesas. In the outcrop the Ojo Alamo is deeply fractured at wide intervals of as much as 15 feet. Soil cover on the outcrop usually is thin and sandy. In contrast to the overlying Animas and Nacimiento Formations, the Ojo Alamo usually supports a modest stand of conifers in areas where there is sufficient precipitation, indicating capture and retention of moisture. Although the unit is relatively thin it is a dependable source of generally good quality water.

\section{Kirtland Shale and Fruitland Formation}

The combined Kirtland Shale and Fruitland Formation, of Late Cretaceous age (Baltz, 1967; Fassett and Hinds, 1971), crops out inside the margins of the central basin. Topography formed on the unit typically varies from rolling to rough, and badlands commonly are developed. Erosionresistant sandstones commonly cap isolated buttes and hillocks, whereas softer shaley units form 
slopes and broad valleys or flats. The upper part of the Kirtland Shale generally forms steep slopes below mesas or buttes that are capped by the overlying erosion-resistant Ojo Alamo Sandstone.

The Kirtland Shale and Fruitland Formation were named by Bauer (1916) for exposures along the San Juan River (fig. 11) west of Farmington, New Mexico. The Ojo Alamo Sandstone of Tertiary age and the McDermott Member of the Animas Formation of Late Cretaceous age (Baltz, 1967; Fassett and Hinds, 1971; Molenaar, 1977b) unconformably overlie the Kirtland Shale. The Kirtland Shale conformably overlies the Fruitland Formation. The Fruitland Formation conformably overlies the Pictured Cliffs Sandstone, and intertonguing locally occurs at the contact.

\section{Geometry and Lithology}

In general, the combined Kirtland Shale and Fruitland Formation consists of various thicknesses of interbedded and repetitive sequences of nonmarine channel sandstone, siltstone, shale, and claystone. Coal beds and carbonaceous shales are common in the Fruitland Formation. The Kirtland Shale does not contain coal and has been divided into three members, which in descending order are the upper shale member, Farmington Sandstone Member, and lower shale member (fig. 5; Bauer, 1916).

Thickness of the combined Kirtland Shale and Fruitland Formation ranges from zero on the east side of the basin, because of pre-Ojo Alamo Sandstone erosion, to a maximum of about 2,000 feet in the northwestern part of the basin (Fassett and Hinds, 1971, p. 22, 26; Molenaar, 1977b, p. 165). A basinwide thickness map of the combined Kirtland Shale and Fruitland Formation is shown in figure 16. Thickness of the Kirtland Shale ranges from zero in the east to about 1,500 feet in the northwest; the upper shale member, Farmington Sandstone Member, and lower shale member each are as much as 500 feet thick (Fassett and Hinds, 1971, p. 26; Molenaar, 1977b, p. 165; Stone and others, 1983, p. 31). The Fruitland Formation ranges in thickness from zero in the east to about 500 feet in the northwest (Fassett and Hinds, 1971, p. 23) and averages about 300 to 350 feet thick (Molenaar, 1977b, p. 165).

The overall structural pattern of that part of the San Juan Basin underlain by the Kirtland Shale and Fruitland Formation is shown in figure 17. The top of the Kirtland Shale and Fruitland Formation decreases from a maximum altitude of about 8,000 feet along the northeastern basin margin to about 3,500 feet in the east-central part of the structural basin.

\section{Hydraulic Properties}

Reported transmissivity and hydraulic-conductivity data for the Kirtland Shale and Fruitland Formation are limited to aquifer tests conducted on five wells. The transmissivity determined from these tests ranges from 0.6 to 130 feet squared per day (Stone and others, 1983, table 5). The only hydraulic conductivity calculated from the tests is 0.00001 foot per day.

The reported or measured discharge from 12 water wells completed in the Kirtland Shale and Fruitland Formation ranges from 1 to 12 gallons per minute and the median is 3 gallons per minute. The specific capacity of six of these wells ranges from 0.01 to 0.42 gallon per minute per foot of drawdown and the median is 0.03 gallon per minute per foot of drawdown. These tests are most probably of wells that produce drinking water from the Farmington Sandstone Member of the Kirtland Shale. 


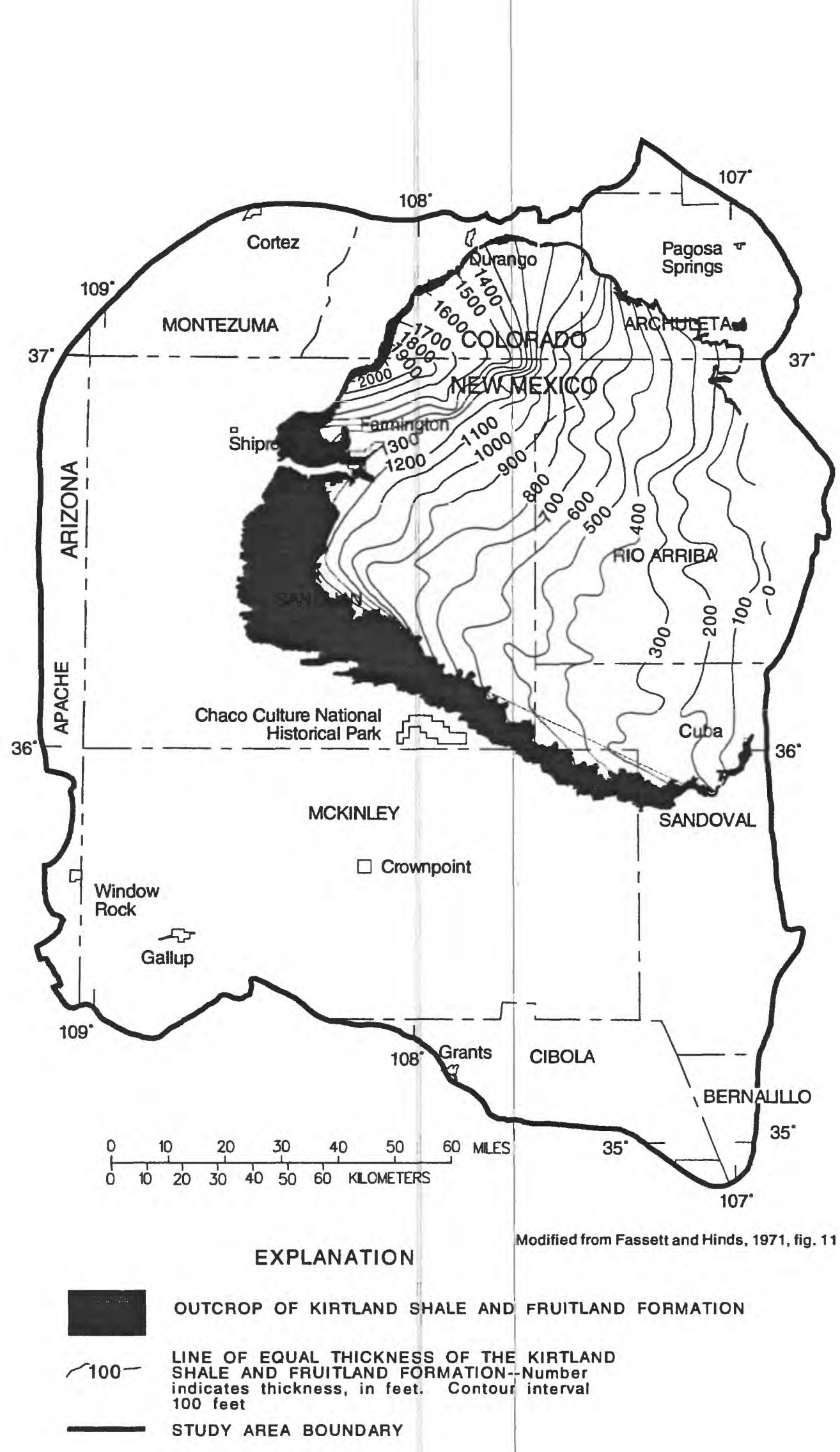

Figure 16.--Approximate thickness of the combined Kirtland Shale and Fruitland Formation. 


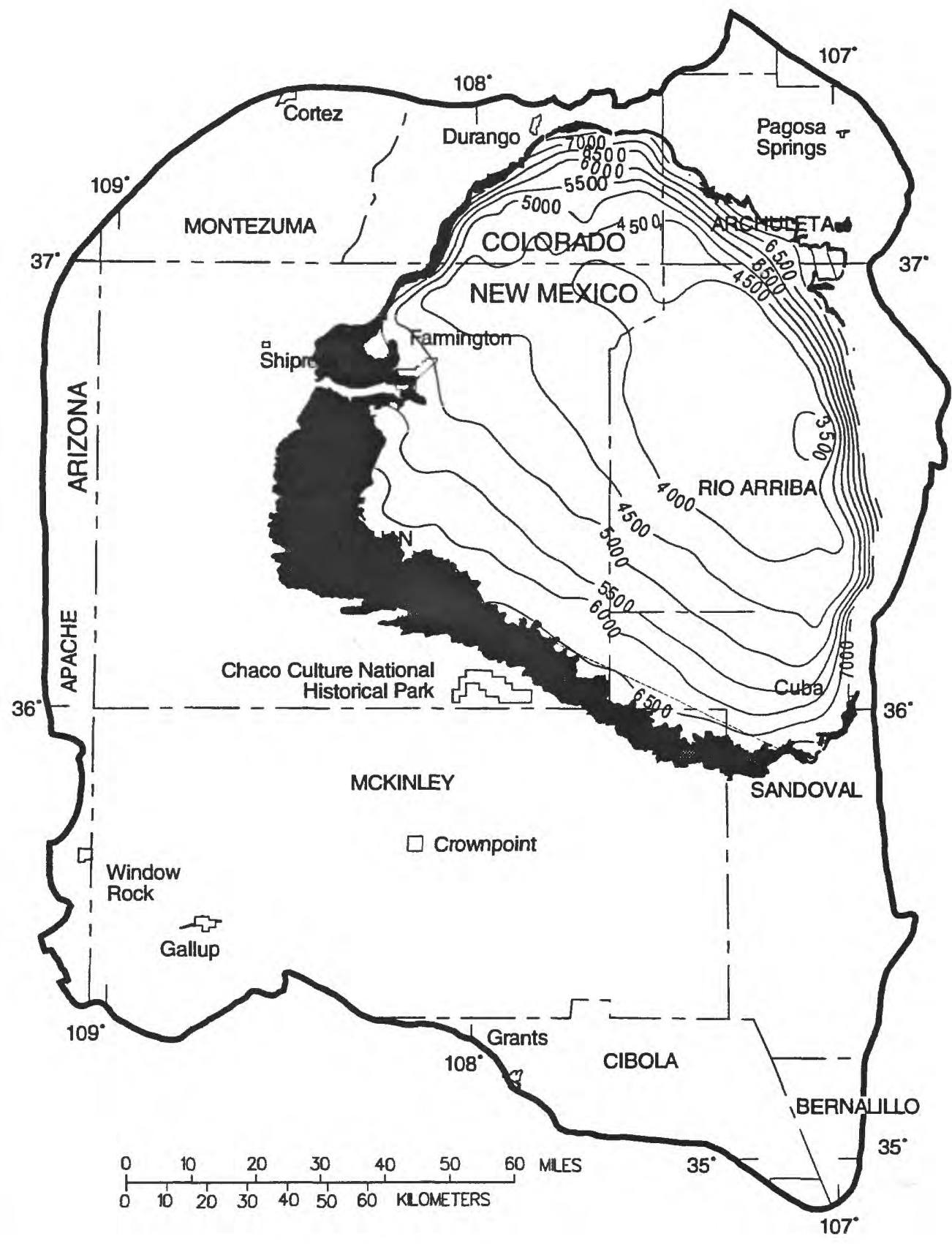

\section{EXPLANATION}

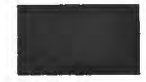

OUTCROP OF KIRTLAND SHALE AND FRUITLAND FORMATION

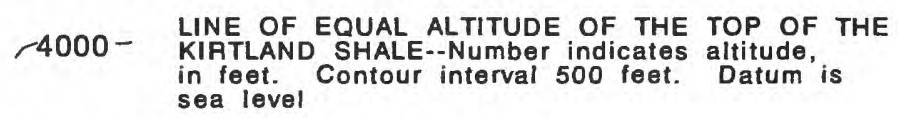

$\longrightarrow$ STUDY AREA BOUNDARY

Figure 17.--Approximate altitude and configuration of the top of the Kirtland Shale. 
Recently, there has been extensive exploration for methane gas resources from coal beds in the Fruitland Formation. The gas resource in the coal beds had largely been ignored because initial production from most wells was large quantities of poor-quality water and the gasproducing potential was not recognized. The current production practice is to complete the well and pump out water to reduce the pressure at the coal bed. Gradually, gas production increases as water production decreases (Fassett, 1989). Because of the poor-quality water and the identification of over-pressured (greater than hydrostatic pressure) areas in the center of the basin at the Colorado-New Mexico State line, a current question among coal geologists is whether the water is connate (trapped in the coal at the time of deposition) or meteoric (originated from recharge on the outcrop).

Some gas and water production is thought to be from both coal in the Fruitland Formation and sandstone in the underlying Pictured Cliffs Sandstone. Water-quality analyses for these two units also show more similarity with each other than with analyses from the overlying Ojo Alamo Sandstone or the underlying Cliff House Sandstone aquifers.

\section{Pictured Cliffs Sandstone}

The Pictured Cliffs Sandstone is of Late Cretaceous age. It crops out inside the margins of the central basin where it caps mesas and buttes or forms erosion-resistant dip slopes. The Pictured Cliffs Sandstone typically is a cliff former, except along the southern outcrop belt where commonly the only way to determine its presence is by drilling. The Pictured Cliffs Sandstone was named by Holmes (1877, p. 248) for exposures having carved petroglyphs near the San Juan River between Shiprock and Farmington, New Mexico.

The Pictured Cliffs Sandstone is a regressive marine coastal-barrier deposit (Molenaar, 1977b, p. 165). It conformably overlies the Lewis Shale (fig. 5). The contact is characterized by a distinct offshore marine transition zone consisting of interbedded thin sandstones, siltstones, and shales (Reeside, 1924, p. 19; Fassett and Hinds, 1971, p. 8). The Fruitland Formation (Late Cretaceous) conformably overlies the Pictured Cliffs, and these two units locally intertongue (Fassett and Hinds, 1971, p. 8).

\section{Geometry and Lithology}

The Pictured Cliffs Sandstone generally consists of an upward-coarsening sequence of thick- to very thick bedded, very fine to medium-grained, locally crossbedded and bioturbated sandstone. Thin interbeds of dark marine shale also are present, especially in the lower part of the unit (Baltz, 1967, p. 17-18; Fassett and Hinds, 1971, p. 8). The Pictured Cliffs is tightly cemented in the northern part of the basin, decreasing to poor or no cementation in the southern part.

Thickness of the Pictured Cliffs Sandstone is variable. Molenaar (1977a) reported a maximum thickness of 400 feet, but also reported (1977b, p. 165) that the average thickness is much less. Fassett and Hinds (1971, p. 17) stated that thickness ranges from 0 feet in the east side of the San Juan structural basin to about 400 feet in the north-central part of the basin. Stone and others (1983, p. 33) reported a range in thickness of 25 to 280 feet in New Mexico.

The configuration of the top of the Pictured Cliffs Sandstone is shown on the structurecontour map (fig. 18). The top of the Pictured Cliffs Sandstone decreases from a maximum altitude of about 8,000 feet along the north-central basin margin to about 3,000 feet in the northeastern part of the study area. 


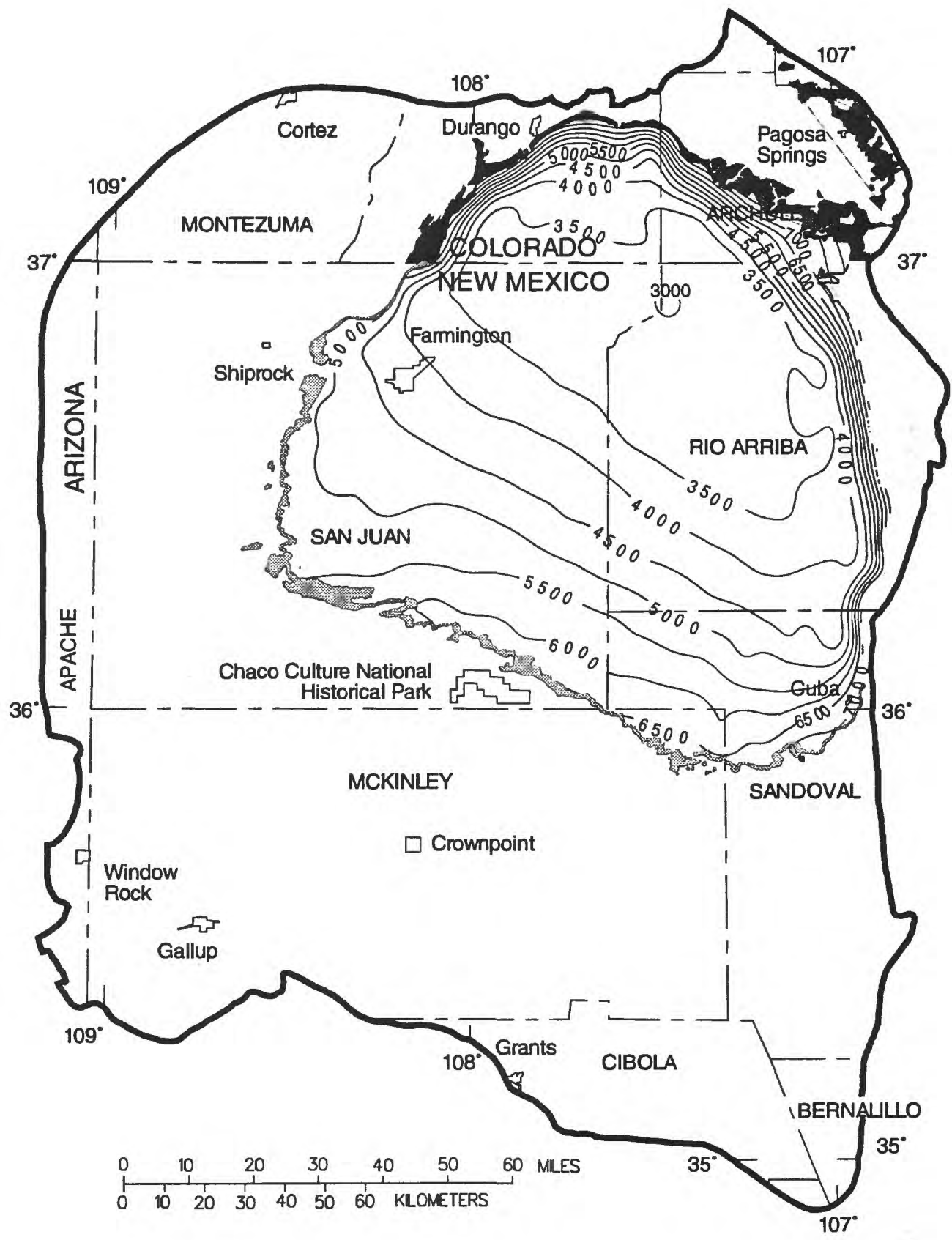

\section{EXPLANATION}

AREAS OF FORMATION OUTCROP:

PICTURED CLIFFS SANDSTONE

PICTURED CLIFFS SANDSTONE AND

LEWIS SHALE, UNDIVIDED

LINE OF EQUAL ALTITUDE OF THE TOP OF THE

PICTURED CLIFFS SANDSTONE--Number indicates

altitude, in feet. Contour interval 500 feet.

Datum is sea level

STUDY AREA BOUNDARY

Figure 18.--Approximate altitude and configuration of the top of the Pictured Cliffs Sandstone. 


\section{Hydraulic Properties}

Reported transmissivity and hydraulic-conductivity data for the Pictured Cliffs Sandstone are minimal. Transmissivity from five tests ranges from 0.001 to 3 feet squared per day (Stone and others, 1983, table 5). Hydraulic-conductivity values calculated from drill-stem tests in oil and gas wells in deeper parts of the basin average 0.007 foot per day (Reneau and Harris, 1957).

The reported or measured discharge from 12 water wells completed in the Pictured Cliffs Sandstone ranges from 2 to 73 gallons per minute and the median is 21 gallons per minute. The specific capacity of seven of these wells ranges from less than 0.01 to 0.70 gallon per minute per foot of drawdown and the median is 0.01 gallon per minute per foot of drawdown.

Few water wells are completed in the Pictured Cliffs Sandstone because of the generally poor quality water found in the unit. In the northern part of the basin the source of water to wells is predominantly from fractures and joints, whereas in the southern part it is from interstitial porosity.

\section{Lewis Shale}

The Lewis Shale, of Late Cretaceous age (fig. 5), crops out around the margins of the central basin. Topography formed on the unit generally is rolling, and badlands landscapes are common. The type area for the Lewis Shale is in the northwestern San Juan Basin.

The Lewis Shale is conformably overlain by the Pictured Cliffs or, in the northeastern part of the San Juan Basin, may be unconformably overlain by the Fruitland Formation, Kirtland Shale, or Ojo Alamo Sandstone. The Lewis conformably overlies and intertongues with the Cliff House Sandstone. In some areas where Cliff House tongues pinch out, the Lewis Shale may directly overlie the Menefee Formation (Stone and others, 1983, p. 33).

\section{Geometry and Lithology}

The Lewis Shale is a gray to dark-gray transgressive marine shale that thins to the west and southwest. In the western part of the basin the Lewis wedges out and the Pictured Cliffs Sandstone rests on the Cliff House Sandstone. The Lewis contains several bentonitic horizons, of which the most widely noted is the Huerfanito Bentonite Bed. The Huerfanito Bentonite Bed is frequently used as a geologic time marker.

The configuration of the top of the Lewis Shale is shown on the structure-contour map (fig. 19). The top of the Lewis Shale decreases from a maximum altitude of about 8,000 feet along the northeastern basin margin to about 3,000 feet in the northeastern part of the central basin.

\section{Hydraulic Properties}

The Lewis Shale is not recognized as an aquifer and there are no known tests to determine the hydraulic properties of the unit. Water wells are reported to be completed in the unit, but these actually may be completed in sandstone tongues of the underlying Cliff House Sandstone.

The Lewis Shale serves as a confining unit that hydraulically separates the overlying Pictured Cliffs Sandstone and underlying Cliff House Sandstone aquifers. The low-permeability shale also rejects recharge from precipitation. 


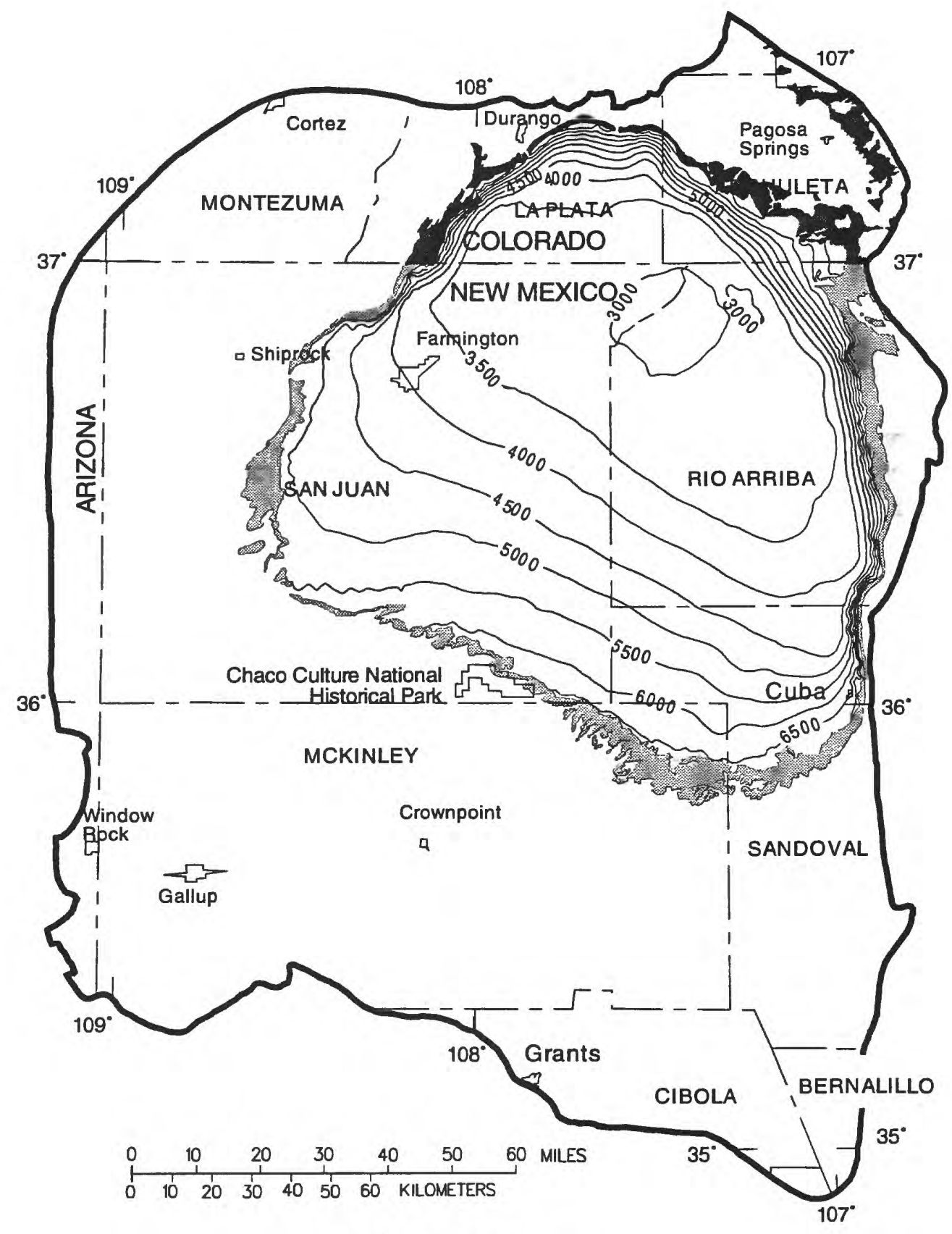

\section{EXPLANATION}

AREAS OF FORMATION OUTCROP:

LEWIS SHALE

PICTURED CLIFFS SANDSTONE AND

LEWIS SHALE, UNDIVIDED

$100^{\circ}$ LINE OF EQUAL ALTITUDE OF THE TOP

OF THE LEWIS SHALE--Number indicates

altitude, in feet. Contour interval 500 feet.

Datum is sea level

STUDY AREA BOUNDARY

Figure 19.--Approximate altitude and configuration of the top of the Lewis Shale. 


\section{Cliff House Sandstone}

The Cliff House Sandstone is of Late Cretaceous age (fig. 5). It crops out around the margins of the central basin and typically caps mesas (as in the Chaco Canyon area at Chaco Culture National Historical Park) and southwest of Cuba, New Mexico) and forms erosionresistant dip slopes and hogbacks (as on the Hogback Monocline) (fig. 4). The Cliff House Sandstone, named by Collier (1919) for exposures on Mesa Verde in southwestern Colorado (fig. 20), is the uppermost formation of the classical three-part|Mesaverde Group of the San Juan Basin (Cliff House Sandstone, Menefee Formation, and Point Lookout Sandstone).

The Cliff House Sandstone is conformably overlain by and intertongues with the Lewis Shale; both of these units conformably and unconformably overlie the Menefee Formation, with which they locally intertongue (Molenaar, 1977b, p. 164; Craigg, 1980, p. 7). In some areas where Cliff House tongues pinch out, the Lewis Shale may directly overlie the Menefee Formation (Stone and others, 1983, p. 33). In the western part of the basin, near the confluence of Coyote Wash and the Chaco River (fig. 11), the Cliff House merges with the Pictured Cliffs Sandstone, wedging out the Lewis Shale (fig. 5). The Cliff House Sandstone strata consist of several thick sandstone tongues that represent marine shorezone deposits of an overall transgressing shallow sea. Molenaar (1977b, p. 164) noted that these sandstone bodies actually are offlap or regressive deposits formed during stillstands and minor regressions of the shoreline.

\section{Geometry and Lithology}

Stratigraphy of the Cliff House Sandstone is complex. Nomenclature problems and differing interpretations tend to complicate regional correlations. The unit consists of two major sandstone tongues--the Chacra Tongue (Molenaar, 1977b, p. 164) and La Ventana Tongue. Several other minor sandstone tongues of considerably less thickness and areal extent are common (Molenaar, 1977b, p. 164; Stone and others, 1983, sheets 2-4), but pinch out to the northeast.

The Chacra Tongue occurs stratigraphically above and is not physically connected to $\mathrm{La}$ Ventana Tongue (Fassett, 1977, p. 196). The Chacra Tongue is the major buildup of the Cliff House Sandstone found at the type section on Mesa Verde, at Chaco Canyon, and at the Hogback Monocline and it forms the margins of the central basin (fig. 4). The unit is about 400 feet thick at its type section on Mesa Verde (fig. 20) (Collier, 1919, p. 297). Molenaar (1977b, p. 164) reported a range of about 150 to 300 feet in thickness, and Stone and others $(1983$, p. 33) reported a range of 0 to 250 feet in thickness of the Chacra Tongue throughout most of its extent in New Mexico.

The major buildup of La Ventana Tongue crops out in the southeastern part of the basin at La Ventana south of Cuba and, according to some authors, can be traced in the subsurface across the basin to outcrops on Hogback Mountain (fig. 20) south of the San Juan River (Fassett, 1977; Molenaar, 1977b, p. 164). Other authors report that La Ventana Tongue is a more localized buildup in the southeastern part of the basin, representing deposition in a deltaic environment rather than a marine beach environment (Mannhard, 1976; Fuchs-Parker, 1977). Maximum thickness of La Ventana Tongue, according to Molenaar (1977b, p. 164), is about 800 feet. However, Mannhard (1976, p. 39) and Fuchs-Parker (1977, p. 199) reported a maximum thickness of about 1,000 feet in outcrops along State Highway 44 south of Cuba. Mannhard (1976), Fuchs-Parker (1977), and Tabet and Frost (1979) showed La Ventana Tongue to pinch out about 15 to 20 miles west of these outcrops. 


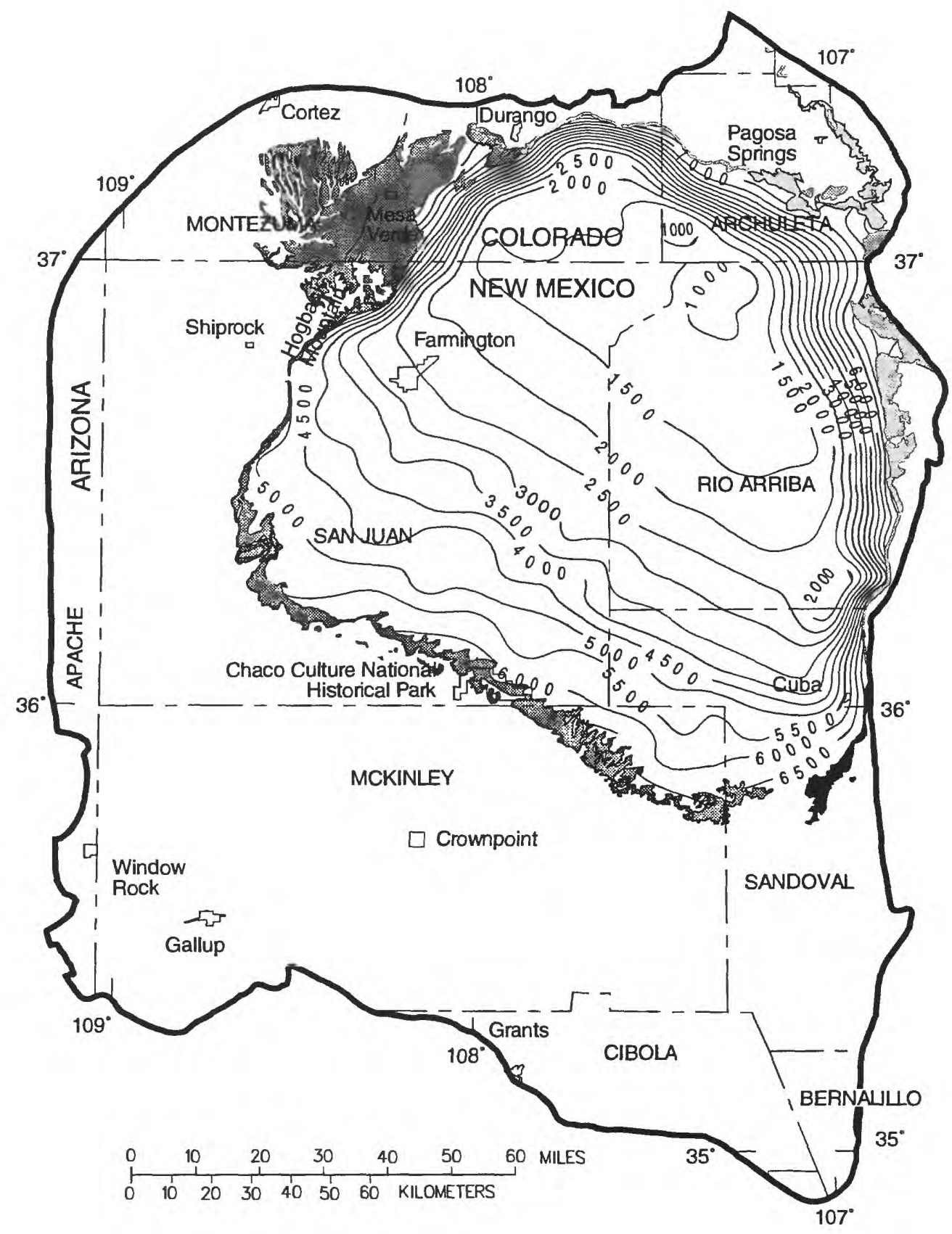

\section{EXPLANATION}

AREAS OF FORMATION OUTCROP:

1 CLIFF HOUSE SANDSTONE

LA VENTANA TONGUE OF CLIFF HOUSE SANDSTONE

MESAVERDE GROUP, UNDIVIDED--Includes Cliff House Sandstone

LINE OF EQUAL ALTITUDE OF THE TOP OF THE CLIFF HOUSE

SANDSTONE, LA VENTANA TONGUE, AND MESAVERDE GROUP.-

Number indicates altitude, in feet. Contour interval 500 feet. Datum

is sea level

STUDY AREA BOUNDARY

Figure 20.--Approximate altitude and configuration of the top of the Cliff House Sandstone. 
Several other minor tongues of the Cliff House Sandstone of limited areal extent occur in the Lewis Shale northeast of the two major sandstone bodies, Chacra Tongue and La Ventana Tongue. Molenaar (1977b, p. 164) reported that the aggregate thickness of these localized bodies is about 300 feet.

The Cliff House Sandstone generally consists of thick- to very thick bedded and locally crossbedded sandstone with calcite or silica cement and clay matrix. Grain size ranges from very fine to fine and the sandstones are well- to very well sorted (Stone and others, 1983, p. 28, 33). Interbeds of gray shale and silty shale are common (O'Sullivan and Beikman, 1963; Haynes and others, 1972; Craigg, 1980).

The configuration of the top of the Cliff House Sandstone is shown on the structure-contour map (fig. 20). The top of the Cliff House Sandstone decreases from a maximum altitude of about 8,000 feet along the northern rim of the central basin to about 1,000 feet near the structural center of the basin. The dip of the Cliff House Sandstone is steepest near the basin margins (where contours are closely spaced), and less steep on the marginal platforms and near the basin center.

\section{Hydraulic Properties}

Transmissivity and hydraulic-conductivity data for the Cliff House Sandstone are extremely limited. A recovery test on a water well in 1961 indicated a transmissivity of 2 feet squared per day (Stone and others, 1983). The average hydraulic conductivity calculated from drill-stem tests in oil and gas wells in deeper parts of the basin is 0.0015 foot per day (Reneau and Harris, 1957).

The reported or measured discharge from 27 water wells completed in the Cliff House Sandstone ranges from 1 to 40 gallons per minute and the median is 8.5 gallons per minute. The specific capacity of 14 of these wells ranges from 0.01 to 0.15 gallon per minute per foot of drawdown and the median is 0.06 gallon per minute per foot of drawdown.

The exposed dip slope of the Cliff House Sandstone offers good recharge potential. The recharge potential is excellent in the northern and northeastern part of the basin where streams cross the outcrop. One of the more probable areas of natural discharge is where the San Juan River crosses the Hogback Monocline (fig. 4) between Farmington and Shiprock, New Mexico.

\section{Menefee Formation}

The Menefee Formation (fig. 21) is of Late Cretaceous age (fig. 5) and crops out beyond the margins of the central basin. Erosion-resistant sandstones in the Menefee commonly cap isolated buttes and hillocks, whereas softer shale units form slopes and broad valleys or flats. Topography formed on the Menefee typically is rolling to rough, broken and steep, and generally has a badlands appearance. The upper part of the Menefee Formation commonly forms steep slopes below mesas or buttes capped by the erosion-resistant Cliff House Sandstone.

The Menefee Formation, named by Collier (1919) for exposures on Menefee Mountain near Mesa Verde in southwestern Colorado, is the middle unit of the classical three-part Mesaverde Group of the San Juan Basin. The Menefee Formation conformably or disconformably overlies the Point Lookout Sandstone and is conformably or disconformably overlain by the Cliff House Sandstone; intertonguing locally occurs at both contacts (Tabet and Frost, 1979; Craigg, 1980; Stone and others, 1983). Some authors have reported the Menefee to be conformably overlain by the Lewis Shale in the southeastern part of the basin (Dane, 1936; Beaumont and others, 1956). South of the pinch-out of the Point Lookout Sandstone in the vicinity of Gallup, New Mexico, the Menefee conformably overlies the Crevasse Canyon Formation (fig. 5). 


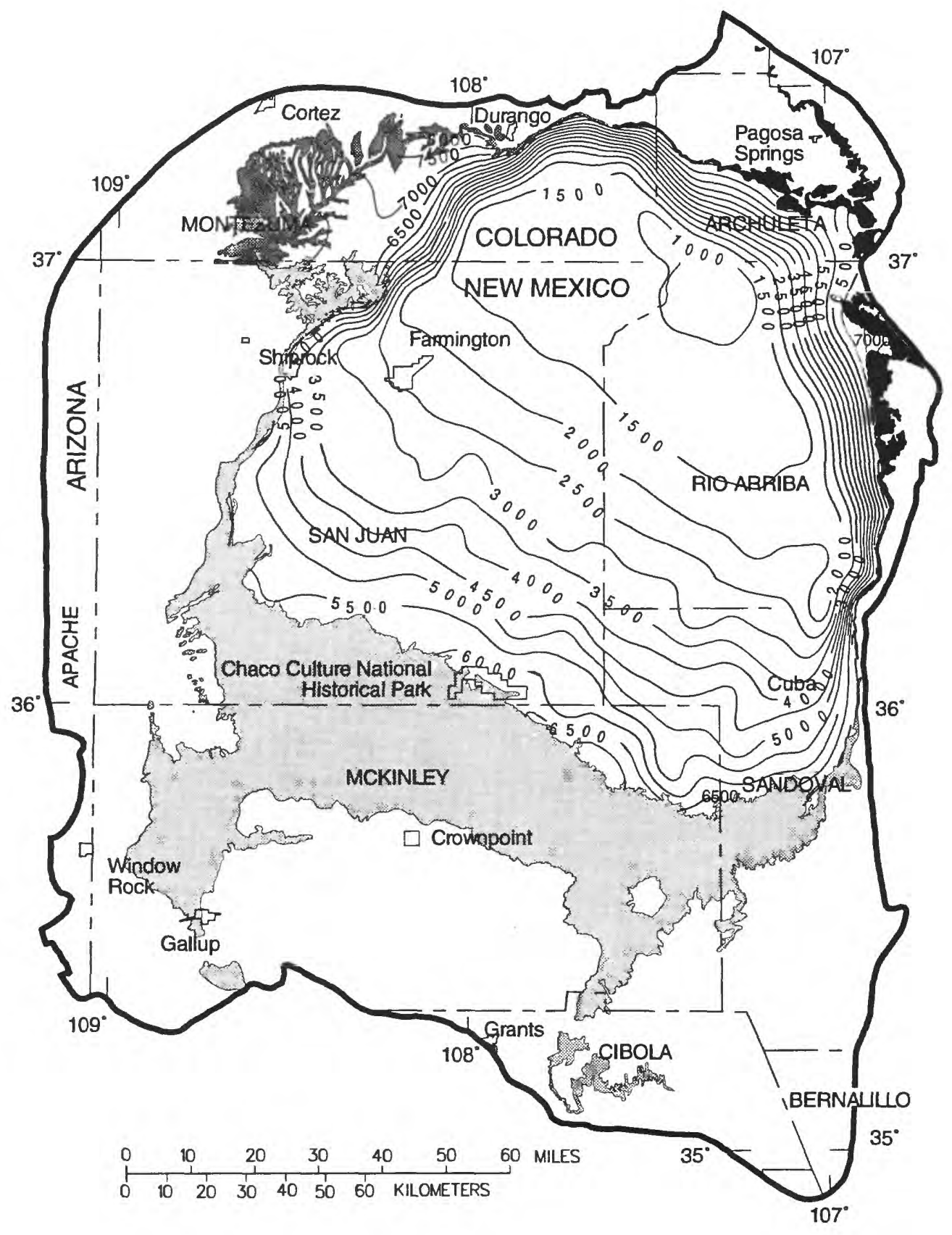

EXPLANATION

AREAS OF FORMATION OUTCROP:

MENEFEE FORMATION

MENEFEE FORMATION AND POINT LOOKOUT SANDSTONE

MESAVERDE GROUP, UNDIVIDED--Includes Menefee Formation

LINE OF EQUAL ALTITUDE OF THE TOP OF THE MENEFEE

FORMATION, POINT LOOKOUT SANDSTONE, AND MESAVERDE

GROUP.-Number indicates altitude, in feet. Contour interval 500

feet. Datum is sea level

STUDY AREA BOUNDARY

Figure 21.--Approximate altitude and configuration of the top of the Menefee Formation. 


\section{Geometry and Lithology}

In general, the Menefee Formation consists of interbedded and repetitive sequences of differing thicknesses of sandstone, siltstone, shale and claystone, carbonaceous shale, and coal beds of differing thicknesses (Collier, 1919; Sears and others, 1936; Mannhard, 1976; Tabet and Frost, 1979; Craigg, 1980). Typically the sandstones are lenticular, light brown to gray, thick to very thick bedded, and fine to medium grained, with clay matrix and various types of cement. The siltstones commonly are tabular, gray, and thin to thick bedded; shales and claystones typically are light-brownish gray and thick to very thick bedded (Mannhard, 1976; Tabet and Frost, 1979; Craigg, 1980).

The Menefee Formation increases in thickness from north to south. Thickness ranges from zero where the unit pinches out between the Point Lookout and Cliff House Sandstones in Colorado to about 2,000 feet along its southern outcrop area (Molenaar, 1977b, p. 164; Tabet and Frost, 1979).

The configuration of the top of the Menefee Formation is shown on the structure-contour map (fig. 21). The top of the Menefee Formation decreases from a maximum altitude of about 8,000 feet along the north-central basin margin to about 1,000 feet in the northeastern part of the study area.

\section{Hydraulic Properties}

The transmissivity of the Menefee Formation depends on the thickness of sandstone lenses penetrated. Transmissivity values reported for nine aquifer tests (Stone and others, 1983) range from 2.7 to 112 feet squared per day and the median value is 10 feet squared per day. Hydraulic conductivity calculated from drill-stem tests in oil and gas wells in deeper parts of the basin averages 0.017 foot per day (Reneau and Harris, 1957).

The reported or measured discharge from 83 water wells and seven springs completed in the Menefee Formation ranges from 2 to 308 gallons per minute and the median is 10 gallons per minute. The specific capacity of 37 of these wells ranges from 0.02 to 0.57 gallon per minute per foot of drawdown and the median is 0.11 gallon per minute per foot of drawdown.

Water from the Menefee Formation is used for livestock watering and domestic purposes. Until a deep well to the Gallup Sandstone was drilled in 1973, the Menefee, supplemented by water from shallow alluvial deposits along Chaco Wash (fig. 11), also was used for the water supply at Chaco Culture National Historical Park. Most wells completed in the Menefee are designed for a low but steady yield of water because the ultimate rate of yield is limited by the rate of leakage of water from shales and silt that encase the lenses of sandstone. Because of the extensive area of the outcrop and the lenticular occurrence of water-yielding sandstones in a clay matrix, the Menefee Formation is both one of the most widely used aquifers and one of the most regionally effective confining units in the basin.

\section{Point Lookout Sandstone}

The Point Lookout Sandstone is of Late Cretaceous age (fig. 5) and crops out beyond the margins of the central basin (fig. 4). The outcrops typically form cliffs, cap mesas and buttes, or form erosion-resistant dip slopes and hogbacks (as along the base of the Hogback Monocline in fig. 4). The Point Lookout Sandstone, named by Collier (1919) for exposures on Mesa Verde in southwestern Colorado, is the lowermost formation of the Mesaverde Group of the San Juan structural basin. It conformably overlies the Mancos Shale throughout the basin, and the contact is characterized by a distinct offshore marine transition zone consisting of interbedded thin sandstones, siltstones, and shales (Shetiwy, 1978; Craigg, 1980; Wright, 1984). The Menefee Formation conformably or disconformably overlies the Point Lookout, and the two units locally intertongue at the contact (Tabet and Frost, 1979). 
In the southern part of the San Juan Basin, the Point Lookout Sandstone is separated into two units by the Satan Tongue of the Mancos Shale (fig. 5). The upper unit is the main body, or by common usage, the Point Lookout Sandstone. The lower unit is the Hosta Tongue, which is a transgressive marine beach sandstone. The main body and Hosta Tongue merge along the southern margin of the basin (fig. 5) into a combined unit about 250 feet thick (Sears and others, 1941; Beaumont and others, 1956, p. 2154). The Hosta Tongue is of limited areal extent, pinching out 30 miles northeast of its outcrop (Beaumont, 1971, p. 22; Craigg, 1980), and attains a maximum thickness of about 160 feet (Beaumont and others, 1956, p. 2155).

\section{Geometry and Lithology}

The Point Lookout Sandstone generally consists of a sequence of thick- to very thick bedded, very fine to medium-grained, locally crossbedded sandstone (Shetiwy, 1978; Craigg, 1980; Wright, 1984). Thin interbeds of dark marine shale also occur, especially in the lower part of the unit.

Thickness of the Point Lookout Sandstone is variable. Beaumont $(1971$, p. 22) reported thickness to range irregularly from about 100 feet in the southern part of the basin to about 350 feet near the Colorado-New Mexico State line. Molenaar (1977a) reported a maximum thickness of 300 feet. Stone and others (1983, p. 34) reported a range from 40 to 415 feet in New Mexico.

The configuration of the top of the Point Lookout Sandstone is shown on the structurecontour map (fig. 22). The top of the Point Lookout Sandstone decreases from a maximum altitude of about 8,000 feet along the north-central and southeastern basin margins to about 500 feet in the northeastern part of the study area.

\section{Hydraulic Properties}

Reported transmissivity of the Point Lookout Sandstone ranges from 0.4 foot squared per day (Craigg, 1980) to 236 feet squared per day (Dames and Moore, 1977; Stone and others, 1983). Dames and Moore reported a storage coefficient of 0.000041 that was based on an analysis of drawdown in an observation well. The average hydraulic conductivity calculated from drillstem tests in oil and gas wells in the deeper parts of the basin is 0.0058 foot per day (Reneau and Harris, 1957).

The reported or measured discharge from 22 water wells completed in the Point Lookout Sandstone ranges from 1 to 360 gallons per minute and the median is 20 gallons per minute. The specific capacity of six of these wells ranges from 0.02 to 1.67 gallons per minute per foot of drawdown and the median is 0.25 gallon per minute per foot of drawdown.

\section{Crevasse Canvon Formation}

The Crevasse Canyon Formation is of Late Cretaceous age (fig. 5). It crops out only in the southern part of the basin. In the western part of the basin the Gibson Coal Member of the Crevasse Canyon forms a rolling, hilly topography in the outcrop. Farther east, the Dalton Sandstone Member commonly is found in cliff-side exposures. 


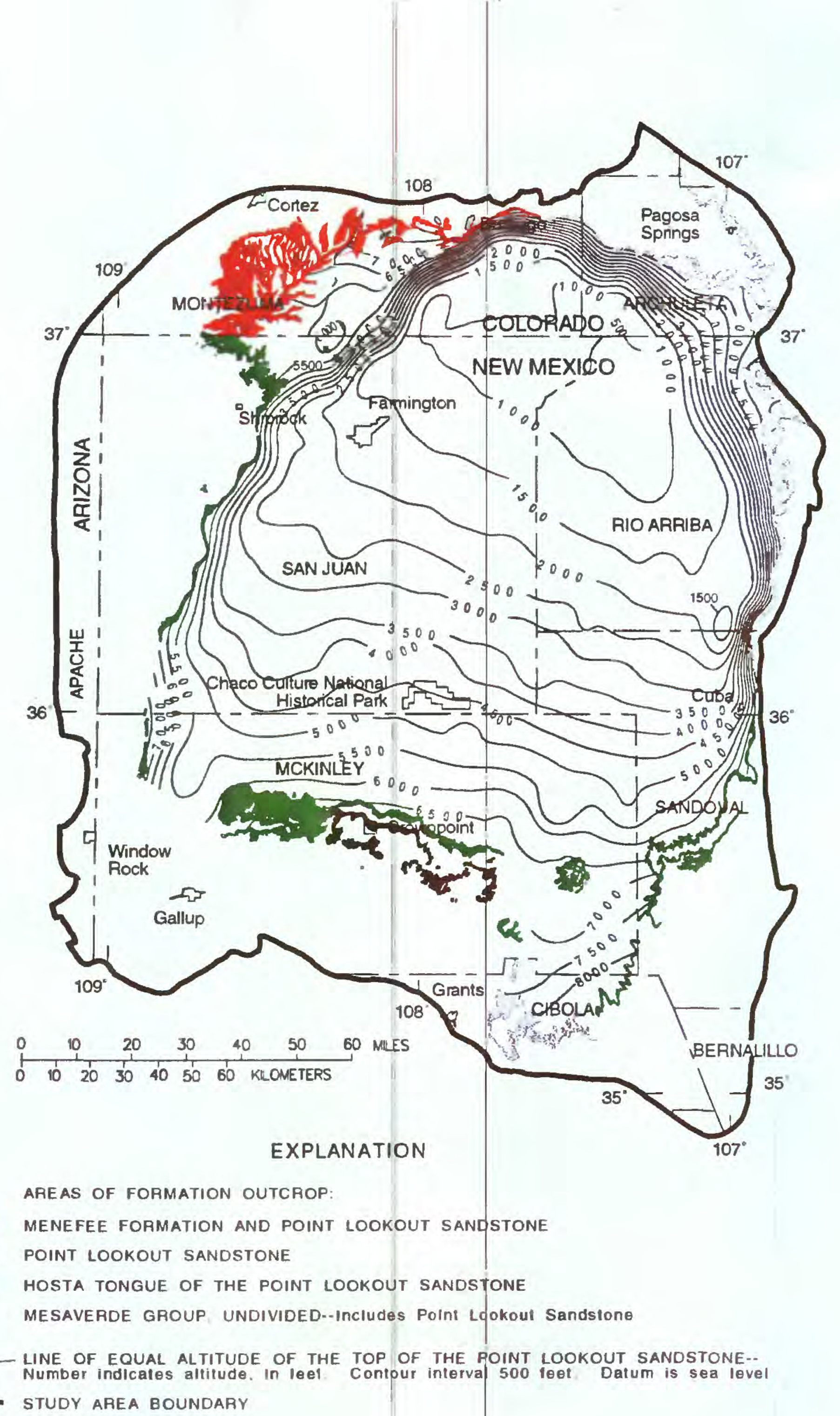




\section{Geometry and Lithology}

The Crevasse Canyon Formation, named by Allen and Balk (1954), consists of three members (fig. 5): the transgressive Dilco Coal Member, the regressive Dalton Sandstone Member, and the transgressive Gibson Coal Member. The thickest occurrence of the Dalton Sandstone is in the vicinity of Mount Taylor (fig. 4) where it has a cliff-side exposure beneath the basalt-capped Mesa Chivato. The Gibson Coal Member is thickest in the southwest part of the basin where it is extensively mined at the surface for its coal resources. The Gibson Coal Member thins to the east as the Dalton Sandstone thickens. The Crevasse Canyon Formation underlies the Hosta Tongue of the Point Lookout Sandstone. South of the pinch-out of the Point Lookout Sandstone in the vicinity of Gallup, New Mexico, the Menefee conformably overlies the Crevasse Canyon Formation (fig. 5). The Crevasse Canyon Formation conformably overlies the Gallup Sandstone. The Crevasse Canyon Formation thins rapidly to the northeast and pinches out about 30 miles northeast of its outcrop.

\section{Hydraulic Properties}

The Dalton Sandstone Member is the primary water-yielding unit of the Crevasse Canyon Formation. Because of its limited extent, however, it is not a major aquifer in the basin. Stone and others (1983) reported a probable transmissivity of less than 50 feet squared per day for sandstones in the Crevasse Canyon Formation.

\section{Gallup Sandstone}

The Gallup Sandstone is of Late Cretaceous age (fig. 5). The unit has a smaller areal extent than the other major Upper Cretaceous marine sandstones in the San Juan structural basin and occurs only in New Mexico and a small part of Arizona. The Gallup Sandstone crops out in an arcuate pattern around the margins of the southwest half of the basin where it typically forms erosion-resistant cliffs and dip slopes.

As originally defined by Sears (1925) and discussed in detail by Dane and others (1957), the Gallup Sandstone consists of various rocks including sandstone (the predominant rock type), conglomerate, shale, carbonaceous shale, and coal. The Gallup Sandstone represents the first major regression of the Upper Cretaceous sea in the San Juan structural basin area and also represents deposition in various marine and nonmarine environments.

\section{Geometry and Lithology}

From its outcrops, the Gallup Sandstone dips toward a northwest-trending cutoff line that extends from the southeastern part of the basin, through the central part of the basin, to near Shiprock, New Mexico, in the northwestern part of the basin. The orientation of this cutoff line is about north 50 degrees west. The Gallup Sandstone is not present northeast of this cutoff line because it has been truncated by a pre-Niobrara erosion surface (Pentilla, 1964; Molenaar, 1973, 1974). Thickness of the Gallup Sandstone decreases from about 600 feet near the outcrops along the southern margin of the basin to zero along the northwest-trending pre-Niobrara cutoff line. 
Isolated, lenticular sandstone bodies known as Tocito Sandstone Lentils are found in the transgressive Mulatto Tongue of the Mancos Shale northeast of the cutoff line. These isolated sandstone lenses have been referred to by various informal names such as "Basal Niobrara sandstone," "Tocito sandstone," "Transgressive Gallup," and "Stray sandstone" and have been misidentified as parts of the main body of the Gallup Sandstone. Although many of these isolated sandstone bodies are found at stratigraphic horizons that suggest the presence of the Gallup Sandstone, they are not connected to nor are genetically related to the main body of the Gallup Sandstone (Molenaar, 1973, 1974).

The approximate altitude and configuration of the top of the Gallup Sandstone are shown on the structure-contour map (fig. 23). The altitude of the top of the Gallup Sandstone decreases from a maximum of about 7,500 feet in the western part of the basin to about 1,500 feet in the westcentral part of the basin.

\section{Hydraulic Properties}

Transmissivity and storage-coefficient data for the Gallup Sandstone are available from analysis of drawdown and recovery data for aquifer tests conducted at 17 wells in the study area (Stone and others, 1983, table 5; McLean, 1980; U.S. Geological Survey files, Albuquerque, New Mexico). Values of transmissivity range from 15 to 390 feet squared per day; the median is 123 feet squared per day. Values of storage coefficient calculated from aquifer tests at four wells range from 0.000002 to 0.000033 .

The reported or measured discharge from 49 water wells completed in the Gallup Sandstone ranges from less than 1 to 645 gallons per minute and the median is 42 gallons per minute. The specific capacity of 13 of these wells ranges from 0.12 to 2.10 gallons per minute per foot of drawdown and the median is $\mathbf{0 . 4 6}$ gallon per minute per foot of drawdown.

The Gallup Sandstone is a major source of potable or treatable water and serves as the main water supply for the City of Gallup, Chaco Culture National Historical Park, and many small public-distribution systems in the southern part of the basin. It is also a major source of water for livestock use, especially in the southeastern part of the basin. The Gallup Sandstone is a source of water containing dissolved-solids concentrations less than 2,000 milligrams per liter throughout the extent of the main body of the sandstone.

\section{Dakota Sandstone}

The Dakota Sandstone generally is thought to be of earliest Late Cretaceous age, although the lowermost part may be of latest Early Cretaceous age (Fassett, 1977, p. 225). The Dakota Sandstone crops out around the basin margins where it typically caps mesas and forms erosionresistant dip slopes and hogbacks.

The Dakota Sandstone in the San Juan structural basin and vicinity was deposited on a regional erosion surface; the strata represent a transition from continental alluvial-plain deposition in the lower part of the formation to marine shorezone deposition in the upper part. Owen (1973, p. 39-50) presented a comprehensive depositional model for the Dakota Sandstone in the area of the San Juan structural basin.

The Dakota Sandstone unconformably overlies the Brushy Basin Member of the Morrison Formation (Late Jurassic age) throughout much of the basin. However, the Dakota overlies the Westwater Canyon Member of the Morrison in the southwest and the Burro Canyon Formation (Early Cretaceous) in the north (fig. 5). The upper contact of the Dakota is conformable with the Mancos Shale, and intertonguing of these two units is common near the contact. 

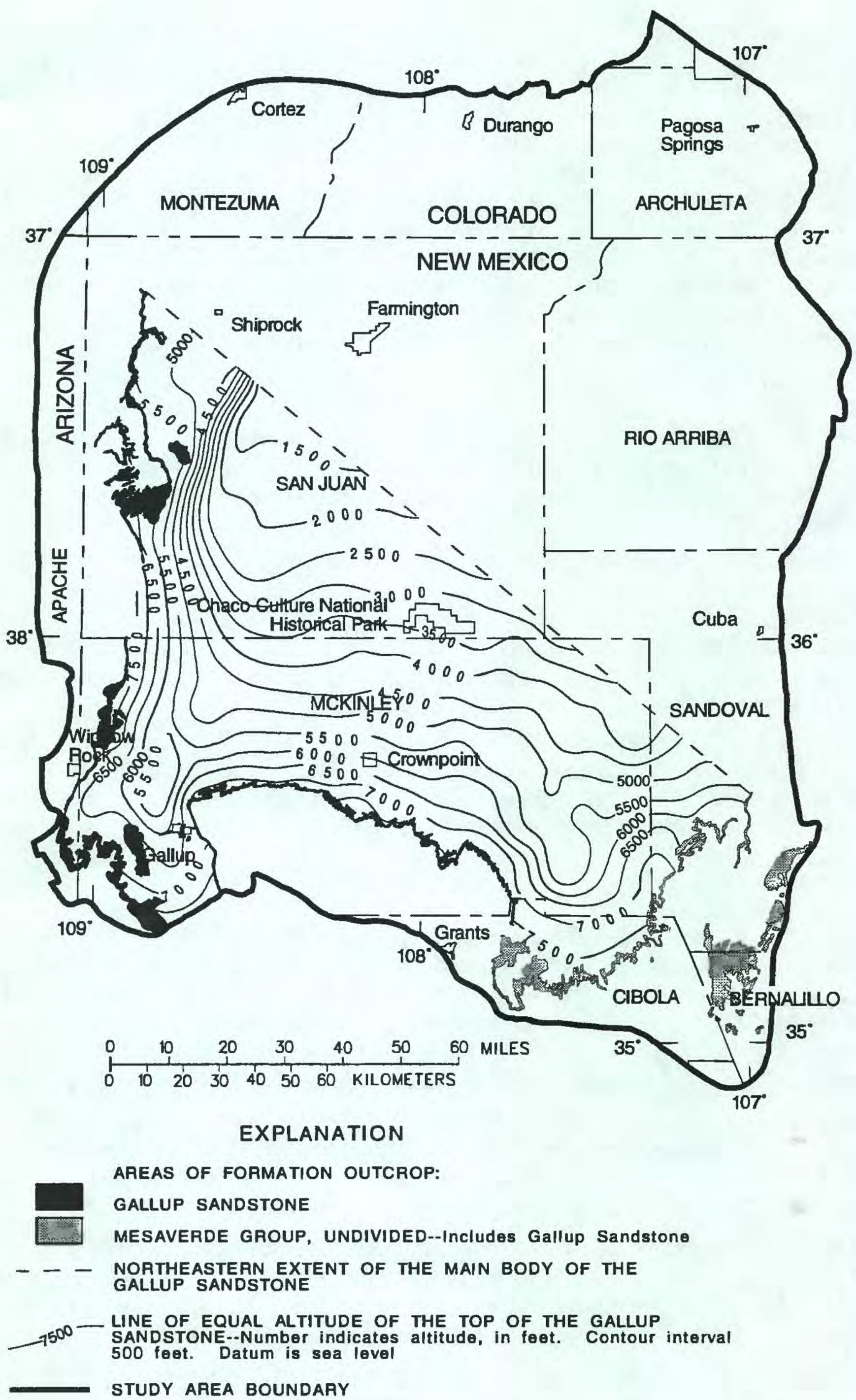

Figure 23.--Approximate altitude and configuration of the top of the Gallup Sandstone. 


\section{Geometry and Lithology}

Stratigraphy of the Dakota Sandstone is complex. The unit consists of a main sandstone body in the north from which various members and tongues extend depending on location in the San Juan structural basin. The Dakota consists of four members (Landis and others, 1973; Owen, 1973), which, in descending order, are the Twowells Tongue, Paguate Tongue, Cubero Tongue, and Oak Canyon Member (fig. 5). The two upper sandstone members intertongue with the Graneros Member of the Mancos Shale. Owen and Siemers (1977) and Noon (1980) have attempted to extend these members in the east part of the basin. Petroleum geologists have applied informal terminology to some of the tongues of the Dakota Sandstone, such as "Dakota A" for the Twowells Tongue and "Dakota B" for the Paguate Tongue (fig. 5).

The Dakota Sandstone contains three principal lithologies. It typically consists of a sequence of buff to brown, crossbedded, poorly sorted, coarse-grained conglomeratic sandstone and moderately sorted, medium-grained sandstone in the lower part; dark-gray carbonaceous shale with brown siltstone and lenticular sandstone beds in the middle part; and yellowish-tan, fine-grained sandstone interbedded with gray shale in the upper part (fig. 5; Owen, 1973, p. 39-48; Merrick, 1980, p. 45-47).

Thickness of the Dakota Sandstone generally ranges from a few tens of feet to about 500 feet; Stone and others $(1983$, p. 37) reported that 200 to 300 feet probably is a more common range. Data reported by Stone and others (1983, fig. 66) and Molenaar (1977b, p. 160-161) and data obtained from Petroleum Information Corporation indicate that the thickness of the Dakota generally increases from the west, northwest, and north margins of the basin toward the east, southeast, and south margins.

The altitude and configuration of the top of the Dakota Sandstone are shown on the structure-contour map (fig. 24). The top of the Dakota Sandstone decreases from a maximum altitude of about 9,500 feet above sea level along the northern basin margin to about 1,500 feet below sea level in the northeastern part of the study area.

\section{Hydraulic Properties}

Transmissivity and hydraulic-conductivity data for the Dakota Sandstone are few. Transmissivity values of 44 and 85 feet squared per day were reported for aquifer tests conducted northeast of Crownpoint, New Mexico (Dames and Moore, 1977, pls. 4 and 5). An aquifer test conducted east of Grants indicated a transmissivity of 2,000 feet squared per day (Risser and Lyford, 1983, p. 166). Hydraulic-conductivity values calculated from drill-stem tests in oil wells in deeper parts of the basin average 0.03 foot per day (Reneau and Harris, 1957, p. 43).

The reported or measured discharge from 30 water wells completed in the Dakota Sandstone ranges from 1 to 75 gallons per minute and the median is 12 gallons per minute. The specific capacity of 13 of these wells ranges from 0.03 to 3.67 gallons per minute per foot of drawdown and the median is $\mathbf{0 . 0 6}$ gallon per minute per foot of drawdown.

In only a few instances is the Dakota Sandstone the sole source of water to a well. The quality of water generally is not as good as that of water from the underlying Westwater Canyon Member of the Morrison Formation (Craigg and others, 1989; Dam and others, 1990a), and most well drillers opt to extend wells into the Westwater Canyon Member.

The Dakota Sandstone has been mined for uranium ore in the southern part of the basin. Also, the Twowells Tongue and upper Paguate Tongue sandstone members that intertongue with the Graneros Member of the Mancos Shale produce oil and gas in the basin. Similar to the transgressive sands of the Gallup Sandstone, these tongues are hydraulically isolated from the ground-water-flow system. 


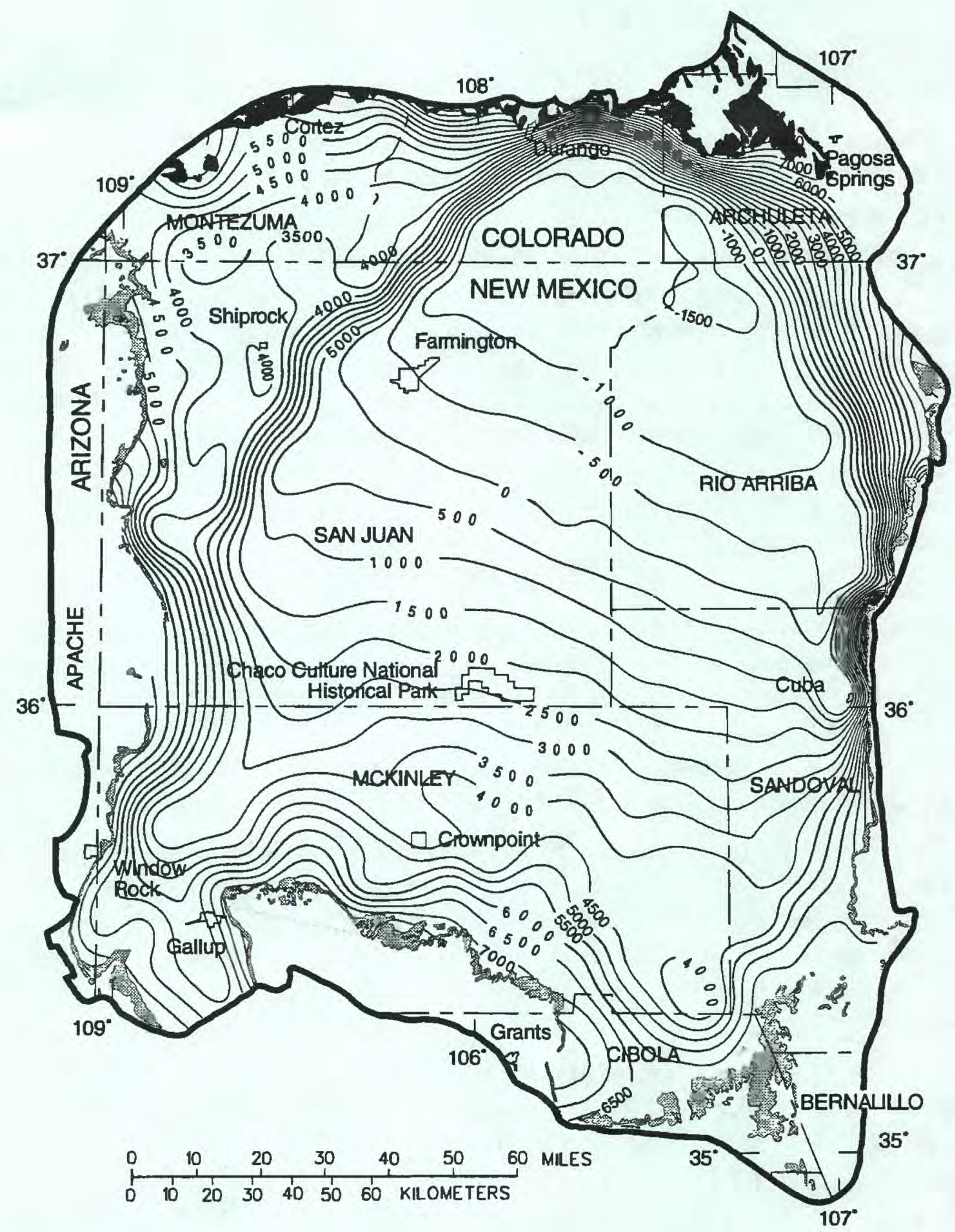

EXPLANATION

AREAS OF FORMATION OUTCROP:

DAKOTA SANDSTONE

DAKOTA SANDSTONE AND BURRO CANYON FORMATION, UNDIVIDED

-6500 - LINE OF EQUAL ALTITUDE OF THE TOP OF THE DAKOTA

SANDSTONE--Number indicates altitude, in feet. Contour interval 500 feet. Datum is sea level

STUDY AREA BOUNDARY

Figure 24.--Approximate altitude and configuration of the top of the Dakota Sandstone. 


\section{Morrison Formation}

The Morrison Formation is of Late Jurassic age (fig. 5; Cadigan, 1967, p. 6) and crops out around the basin margins. Major sandstones in the Morrison Formation typically form erosionresistant cliffs and dip slopes, whereas shale units form topographic saddles and dip slopes.

The Morrison Formation is present throughout the San Juan structural basin (Green and Pierson, 1977, p. 151). It conformably overlies the upper part of the Wanakah Formation or Cow Springs Sandstone of Late Jurassic age (Condon and Peterson, 1986, p. 24). In the north part of the basin, the Morrison Formation conformably overlies and probably intertongues with the Junction Creek Sandstone of Late Jurassic age (fig. 5). The Morrison Formation is unconformably overlain by the Dakota Sandstone of Late Cretaceous age throughout most of the San Juan Basin; however, it is conformably overlain by the Burro Canyon Formation of Early Cretaceous age in the northern part of the basin (fig. 5; Green and Pierson, 1977, p. 151).

\section{Geometry and Lithology}

The Morrison Formation generally consists of yellowish-tan to pink, fine- to coarse-grained, locally conglomeratic sandstones, which are interbedded with sandy siltstones and green to reddish-brown shales and claystones; minor limestone beds also occur in the formation (Woodward and Schumacher, 1973, p. 3-5; Green and Pierson, 1977, p. 151; Stone and others, 1983, p. 38). These strata were deposited in various continental environments including stream channels, flood plains, and lakes (Green and Pierson, 1977, p. 151).

In the San Juan structural basin the Morrison Formation consists of five members (Gregory, 1938; Craig and others, 1955; Cadigan, 1967; Green and Pierson, 1977; Owen, 1984). These members in descending order are the Salt Wash Member, Recapture Member, Westwater Canyon Member, Brushy Basin Member, and Jackpile Sandstone Member. Recently the Zuni Sandstone was assigned to the Morrison Formation as an eolian facies of the Recapture Member (Condon, 1989).

Because of its geologic characteristics the Westwater Canyon Member is the most important hydrologic unit of the Morrison Formation. Kelly (1977) described the hydrogeology of this member in the south part of the basin. The Westwater Canyon Member is composed of yellowishgray to tan, pink or light-brown, fine- to coarse-grained locally conglomeratic sandstone, interbedded with shale or claystone (Craig and others, 1955, p. 153; Woodward and Schumacher, 1973, p. 3). Grains increase in size toward the west-central part of the basin until the member consists wholly of conglomeratic sandstone (Craig and pthers, 1955, p. 154). Thickness of the Westwater Canyon Member increases from about 100 feet on the north, east, and south sides of the San Juan Basin to about 300 feet in the west-central part of the basin (Craig and others, 1955, p. 154).

The altitude and configuration of the top of the Morrison Formation are shown on the structure-contour map (fig. 25). The top of the Morrison Formation decreases from a maximum altitude of about 10,000 feet above sea level along the northern basin margin to about 1,500 feet below sea level in the northeastern part of the basin.

The composite thickness of all members of the Morrison Formation is shown in figure 26. The composite thickness generally correlates with the thickness of the Westwater Canyon Member. 


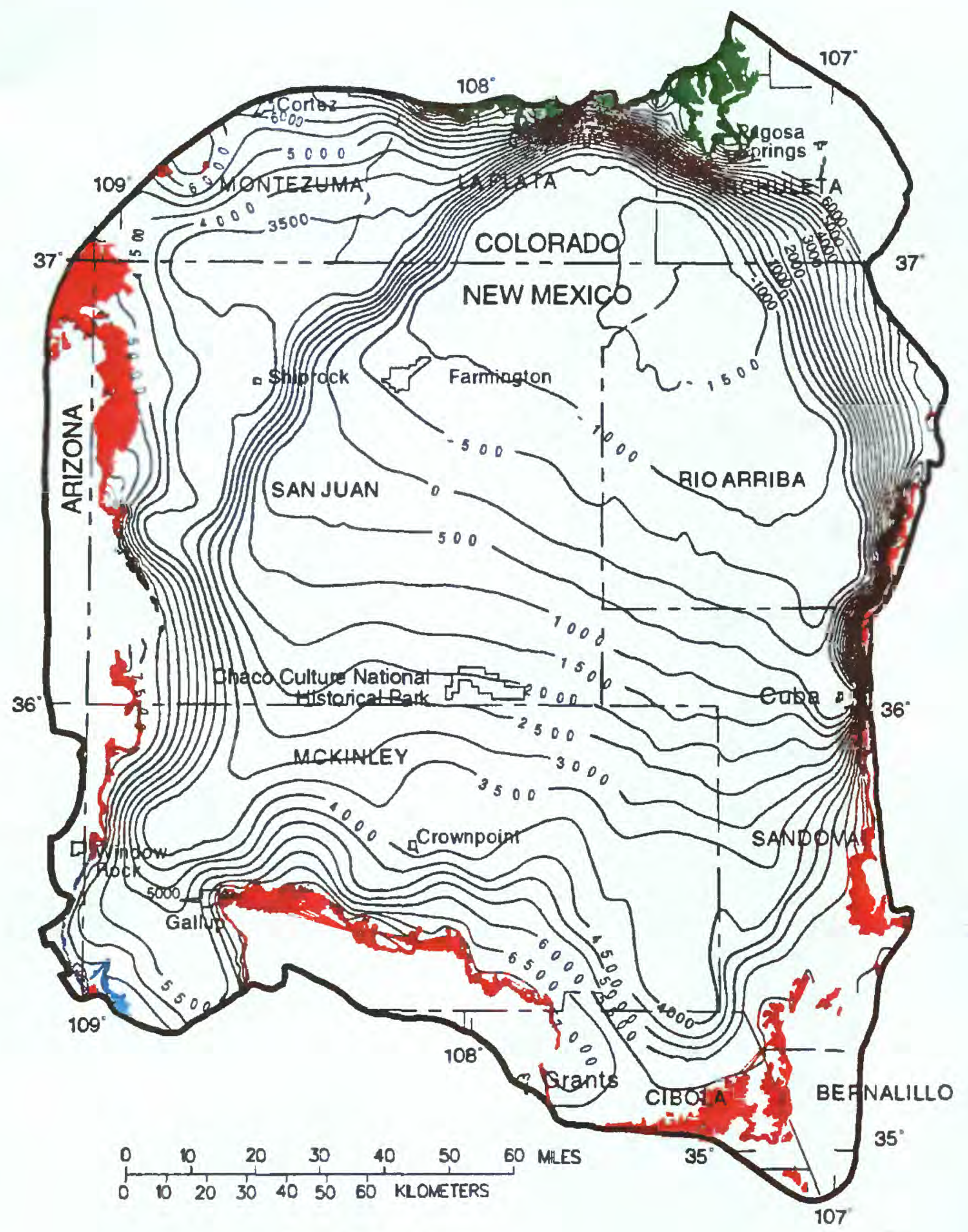

EXPLANATION

AREAS OF FORMATION OUTCROP:

MORRISON FORMATION

ZUNI SANDSTONE. OF FORMER USAGE

SAN RAFAEL GROUP

MORRISON AND WANAKAH FORMATIONS AND ENTRADA SANDSTONE, UNDIVIDED

- JURASSIC ROCKS, UNDIVIDED $>_{s} s_{0}$ - LINE OF EOUAL ALTITUDE OF THE TOP OF THE MORRISON 500 feet. Datum is sea level

STUDY AREA BOUNDARY

Figure 25.--Approximate altitude and configuration of the top of the Morrison Formation. 


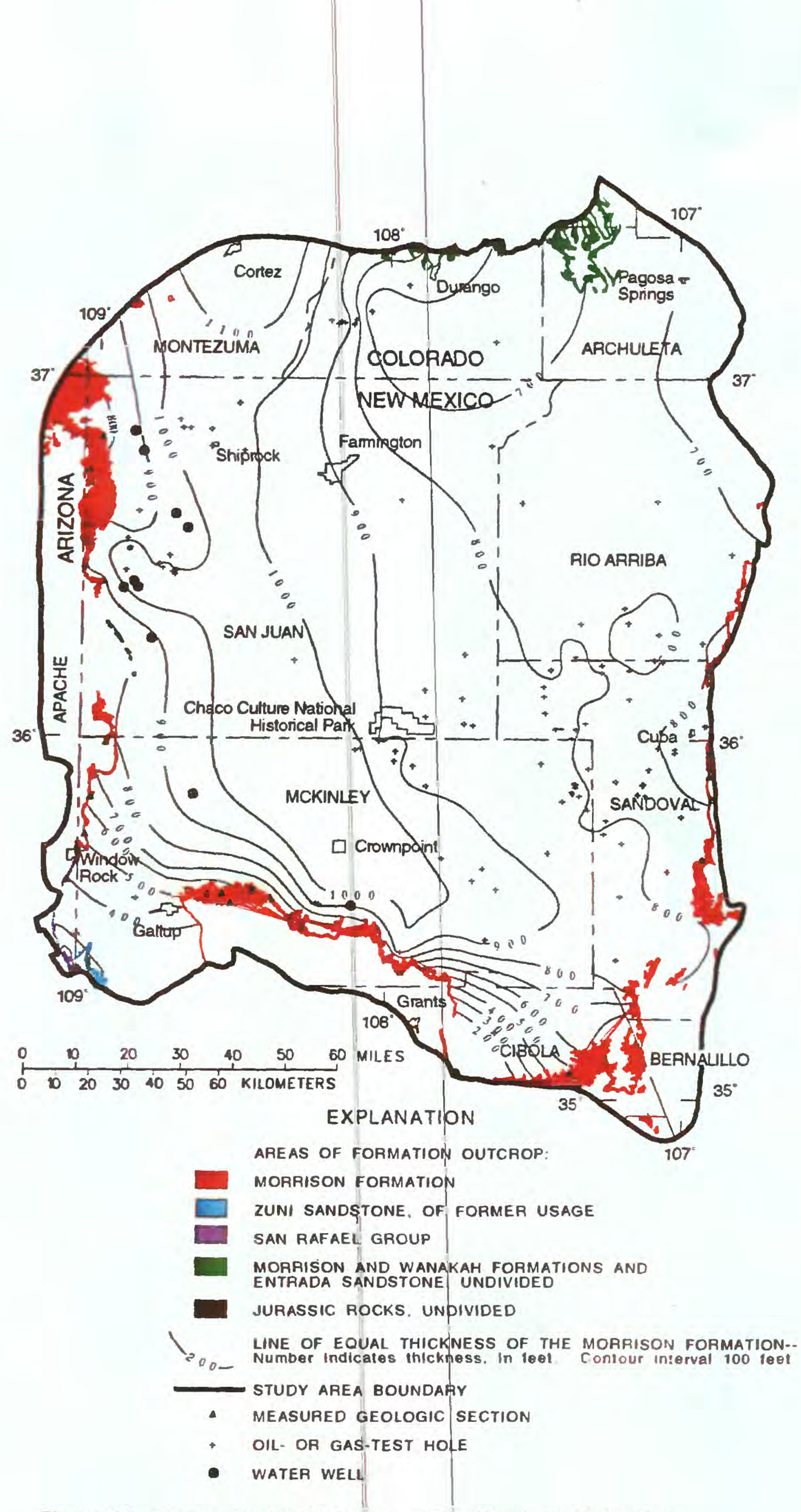

Figure 26.--Approximate thickness of the Morrison Formation. 


\section{Hydraulic Properties}

Transmissivity, storage coefficient, and hydraulic-conductivity data for the Morrison Formation are available from drawdown and recovery aquifer tests conducted at 31 wells in the study area (Stone and others, 1983, table 5; Risser and others, 1984, p. 23). The transmissivity ranges from 2 to 480 feet squared per day and the median value is 115 feet squared per day. The storage coefficients calculated from aquifer tests at nine wells range from 0.00002 to 0.0002 . Hydraulic-conductivity values for three wells range from 0.025 to 0.39 foot per day. A U.S. Department of the Interior report (1986) listed a hydraulic conductivity of 0.3 foot per day for the Jackpile Sandstone and sandstone lenses in the Brushy Basin Member. For a groundwater-flow model of the Westwater Canyon Member northeast of Gallup, New Mexico, Hearne (1977) simulated the aquifer as having a transmissivity of 300 feet squared per day, a confined storage coefficient of 0.0002 , and an unconfined storage coefficient of 0.10 .

The reported or measured discharge from 83 water wells completed in the Morrison Formation ranges from 1 to 2,250 gallons per minute; the median discharge is 30 gallons per minute. The specific capacity at 32 of these wells ranges from 0.01 to 3.98 gallons per minute per foot of drawdown and the median is 0.42 gallon per minute per foot of drawdown.

One of the major influences on water levels in the Morrison Formation has been aquifer dewatering associated with uranium mining. The location and approximate extent of selected uranium mines in the study area are shown in figure 27. Uranium mining had a modest beginning in the late 1940's, but the industry was well established by the early 1950's. Ore production increased in the mid-1960's and overall mining activity peaked in the late 1970's. By 1981-82, low demand and low prices forced the closure of some mines (primarily the open-pit and underground operations). By 1986 all but one mine had ceased operation. Ground-water levels in the Morrison declined as a result of increased mine dewatering and ore leaching during the growth years of the industry. Later, as mining activity decreased and eventually came to an end in 1991, ground-water levels began to recover.

All wells in the southern part of the study area for which water-level hydrographs have been drawn respond to some degree to uranium-mining activities. Operation of the mines requires the removal of ground water from the aquifer; this results in a reduction in potentiometric head in the aquifer. The rate and extent of reduction are less near the outcrop, where water in the aquifer is under water-table conditions, than in confined areas in the interior of the basin where the Morrison Formation is a confined aquifer. The primary uranium ore body is the Jackpile Sandstone Member of the Morrison Formation.

Three methods of ore extraction have been used in the study area. Open-pit mining techniques were used in the area east of Grants, New Mexico (and to a much lesser extent in the discovery area west-northwest of Grants). This mining method commonly uses gravity flow and existing drainages to remove mine seepage. Open-pit mines usually are within or very near the outcrop area of the formation; the effects of dewatering for open-pit mining are buffered by watertable storage coefficients and reduced transmissivity of the water-yielding units (a function of reduced saturated thickness). Also, the regional base elevation for ground-water discharges usually is only slightly altered from preexisting natural conditions. 


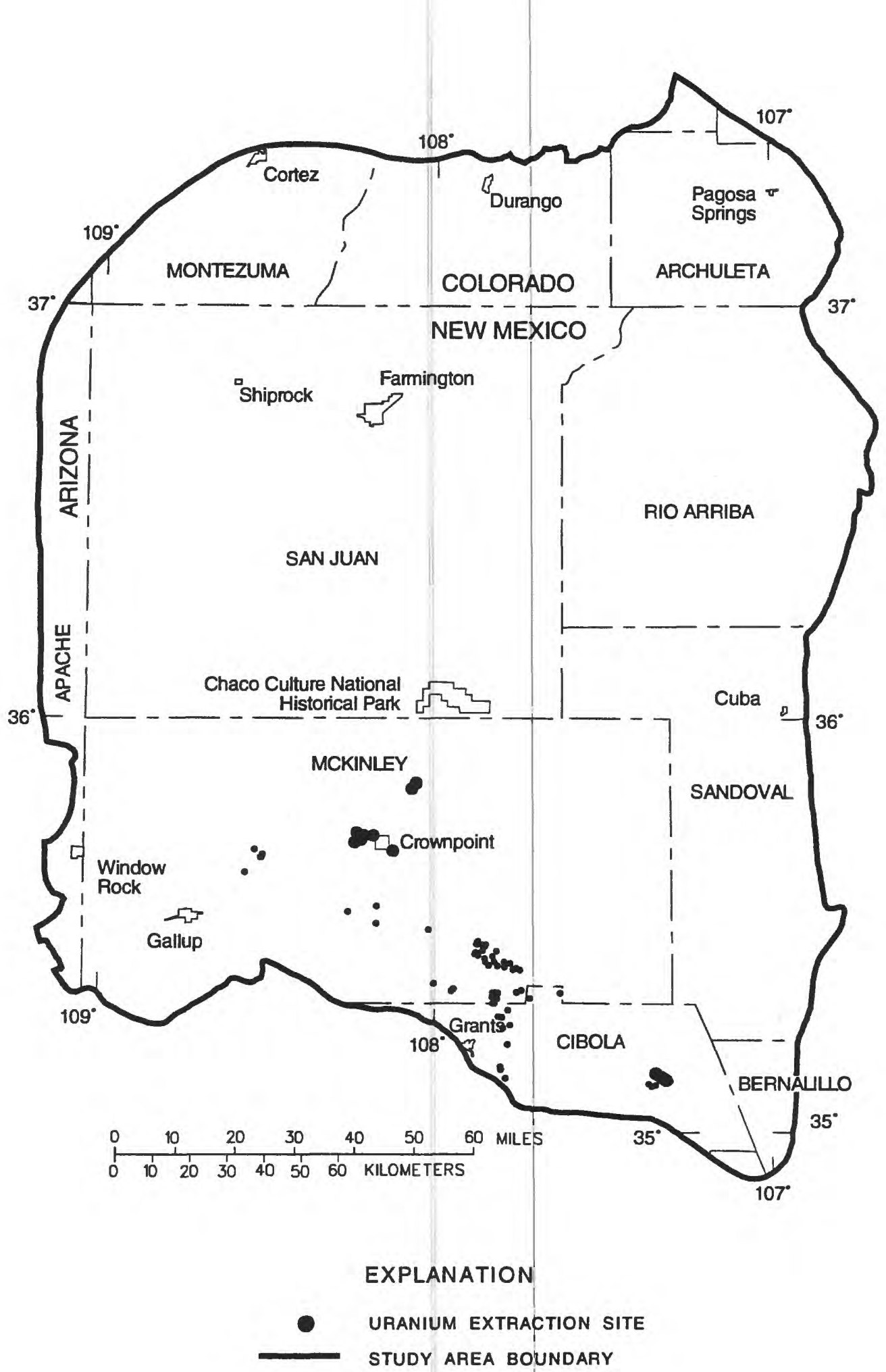

Figure 27.--Location of uranium extraction sites in the Grants uranium belt. 
Deep underground mining methods were used east, north, and northwest of Grants, New Mexico, and northeast of Gallup, New Mexico. This mining practice usually has a more immediate and intense effect on regional ground-water levels than open-pit mining because the aquifer is under confined (artesian) conditions rather than unconfined (water-table) conditions. Typically, potentiometric heads will respond two or three orders of magnitude more quickly to a change in withdrawal in the confined part of an aquifer than in the unconfined part. Also, at any specific time after initiation of withdrawal, equal changes in potentiometric head will be measured at distances of at least one order of magnitude greater in the artesian part of the aquifer than in the unconfined part.

In situ leaching techniques were used at several mines in the Crownpoint, New Mexico, area. Commonly, a concentrated oxidant was injected into the mineralized zone in a pattern of wells forming a square. At the center of the square a single well was used to extract the leachate that contained the uranium. In the process, more fluid was extracted than was injected, causing a net decline in pressure head that propagated through the confined aquifer. 


\section{Wanakah Formation}

The Wanakah Formation, of Jurassic age (fig. 5), crops out at the extreme margins of the basin. Evaporite beds in the Wanakah Formation are moderately resistant to mechanical weathering and form low ridges or crop out in cliff faces under protective caps of younger sandstones of the Dakota Sandstone and Morrison Formation.

The Wanakah Formation is present throughout the San Juan structural basin. It conformably overlies the Entrada Sandstone of Jurassic age. Throughout most of the basin the Wanakah Formation is conformably overlain by the Recapture Member of the Morrison Formation, but in the south it is overlain by the Cow Springs Sandstone and in the north by the Junction Creek Sandstone (fig. 5).

\section{Geometry and Lithology}

The Wanakah Formation, as recently redefined (Condon and Huffman, 1988; Condon, 1989), consists of three members. In descending order they are the Horse Mesa, Beclabito, and Todilto Limestone Members. The Horse Mesa and Beclabito Members were previously defined as the Summerville Formation described by Gilluly and Reeside (1928). These members are a massive to planar bedded sandy siltstone and fine-grained silty sandstone as much as 60 feet thick (Green and Pierson, 1977). A basal siltstone grades into limestone and gypsum-anhydrite of the underlying Todilto Limestone Member. The Todilto Limestone Member consists of a basal limestone as much as 30 feet thick. An upper gyspum-anhydrite facies is present in the eastern part of the basin where it reaches a thickness of as much as 90 feet.

The Wanakah Formation is the lowest unit for which a structure-contour map has been prepared for this report (fig. 28). Control for structure maps diminishes very rapidly for lower units and is insufficient for constructing structure maps that do not conflict with maps showing the top of the Wanakah Formation and younger units.

\section{Hydraulic Properties}

The Wanakah Formation is usually regarded as a confining unit (Thomas, 1989), although sands in the upper part of the unit might yield small quantities of probably poor quality water. There are no known determinations of hydraulic properties of the Wanakah Formation. Recharge to the unit probably is negligible, but solution openings are known to exist in the gypsumanhydrite facies in the southeastern part of the basin, indicating some secondary permeability in the unit. 


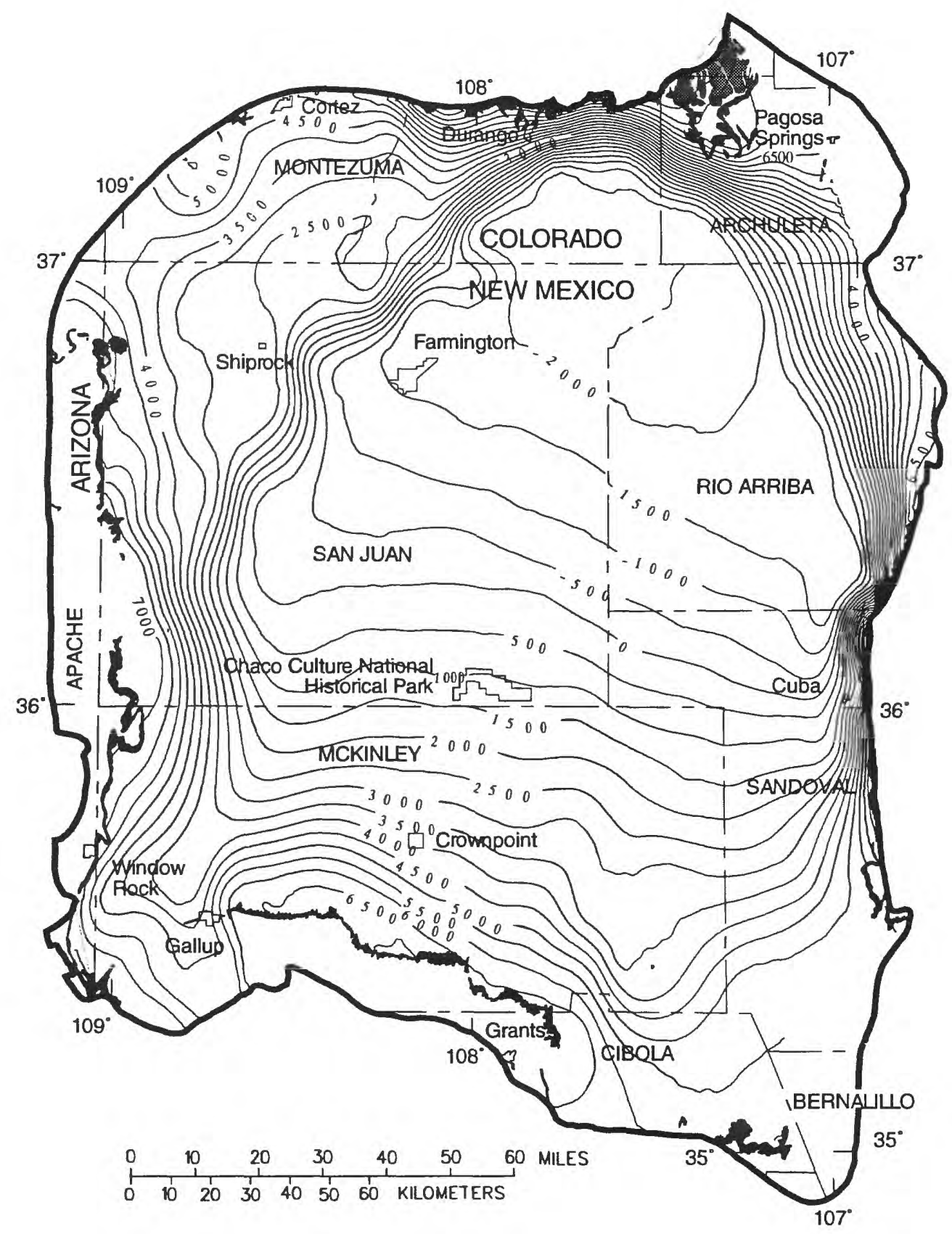

\section{EXPLANATION}

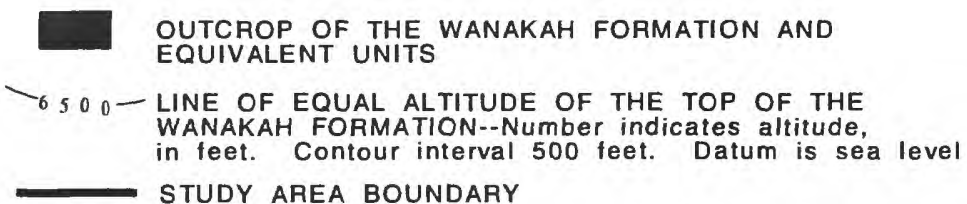

Figure 28.--Approximate altitude and configuration of the top of the Wanakah Formation. 


\section{Entrada Sandstone}

The Entrada Sandstone is the lowest hydrostratigraphic unit considered in this investigation. The Entrada Sandstone (Gilluly and Reeside, 1928), of Jurassic age (fig. 5), is present throughout the basin and crops out at the perimeter of the basin where it forms cliffs, often capped by the Todilto Limestone Member of the Wanakah Formation, or weathers to rounded hills. The Entrada was formerly misidentified as the Wingate Formation by early investigators (Dutton, 1885).

\section{Geometry and Lithology}

In the San Juan Basin the Entrada Sandstone is conformably overlain by the Wanakah Formation and unconformably overlies the Triassic Chinle Formation. The Entrada predominantly is a reddish-orange, massive-bedded, fine- to medium-grained eolian sandstone with some interbedded siltstone. Thickness of the Entrada Sandstone in the San Juan Basin is reported to range from about 60 to 350 feet (Green and Pierson, 1977), but in the southern part of the basin where the unit is used as a water supply it is commonly about 130 feet (Stone and others, 1983).

\section{Hydraulic Properties}

Stone and others (1983) reported transmissivity values of less than 50 feet squared per day that were based on the results of several specific-capacity tests. Fassett and others (1977) reported values of hydraulic conductivity ranging from 0.5 to 5 feet per day from drill-stem tests in oil wells.

Wells producing potable water from the Entrada Sandstone generally are completed near the outcrop along the southern basin margin. Reported well yields from six wells completed in the Entrada Sandstone range from 3 to 200 gallons per minute. The average well yield is 40 gallons per minute and the median is about 5 gallons per minute.

In other areas of the basin the Entrada Sandstone produces oil and (or) highly mineralized water. Water that is recovered with oil often is reinjected into the unit. The Entrada also is used for disposal of oil-field brines produced from other units. 


\section{NATURAL BOUNDARIES OF THE GROUND-WATER-FLOW SYSTEM}

A ground-water-flow boundary is any physical feature or mechanism that alters the movement of water in the ground-water-flow system, or is a sink or source of water to the system. The San Juan Basin, as defined for this investigation, is a virtually self-contained ground-waterflow system whose boundaries generally are clearly defined. These boundaries may be internal or limiting geologic features, surface or subsurface sources or sinks, or contrasts in the properties of the pore-filling liquids.

\section{Geologic Boundaries}

Faults, dikes, changes in hydraulic properties, and geometry of the hydrostratigraphic units are examples of geologic boundaries. Boundaries may define the limits of the flow system but, more generally, are internal to the system and cause redirections of ground-water movement within the basin.

Faults (fig. 7) may act as a flow barrier by partly or completely offsetting aquifers and confining units. The Nacimiento Fault along the Nacimiento Uplift, which has a vertical displacement of several thousand feet, places Precambrian granite against the younger sedimentary rocks in the basin, thereby forming a part of the eastern boundary of the groundwater-flow system. Although faulting is common in the Puerco Fault Zone, located in the southeastern part of the study area, most of the faults lack sufficient displacement to completely offset hydrostratigraphic units over a significant distance.

Faulting also can cause nearby fractures in friable rocks, leading to a local increase in permeability and porosity. For example, a well completed in a fracture zone near a fault might have an atypically large yield, or a fracture zone may connect aquifers across a confining unit or with land surface to form springs. The Puerco Fault Zone has probable examples of all these phenomena. Therefore, the net effect of faulting on ground-water movement is sometimes difficult to predict.

Dikes also may have unpredictable effects on the movement of ground water. Numerous dikes are in the basin but most are relatively narrow ( 2 feet or less) and extend only short distances (a few hundred feet). Most of these dikes are associated with volcanic necks in the Rio Puerco Valley (fig. 11) and Mount Taylor area (fig. 29). These generally have vesicular chill boundaries with the host rock and are highly fractured. Selenite (gypsum) crystals occur at land surface in association with many of these, indicating that the dike is a point of ground-water discharge. In other cases, one or more springs may be associated with the dikes. At depth, these dikes may be a barrier to horizontal ground-water flow but, because of their limited extent, probably are not significant on a regional scale.

Other dikes in the northeastern part of the study area may have a much greater influence on regional ground-water flow. This set of associated dikes (other lesser dikes are present that resemble those in the Rio Puerco Valley) is several feet across and extends as much as $\mathbf{3 0}$ miles in a nearly straight north-south direction. These dikes are dense and form erosion-resistant spines supporting north-south ridges. They do not seem to be associated with surface manifestations of ground water, but one dike, near Dulce, produces a seep of oil. 


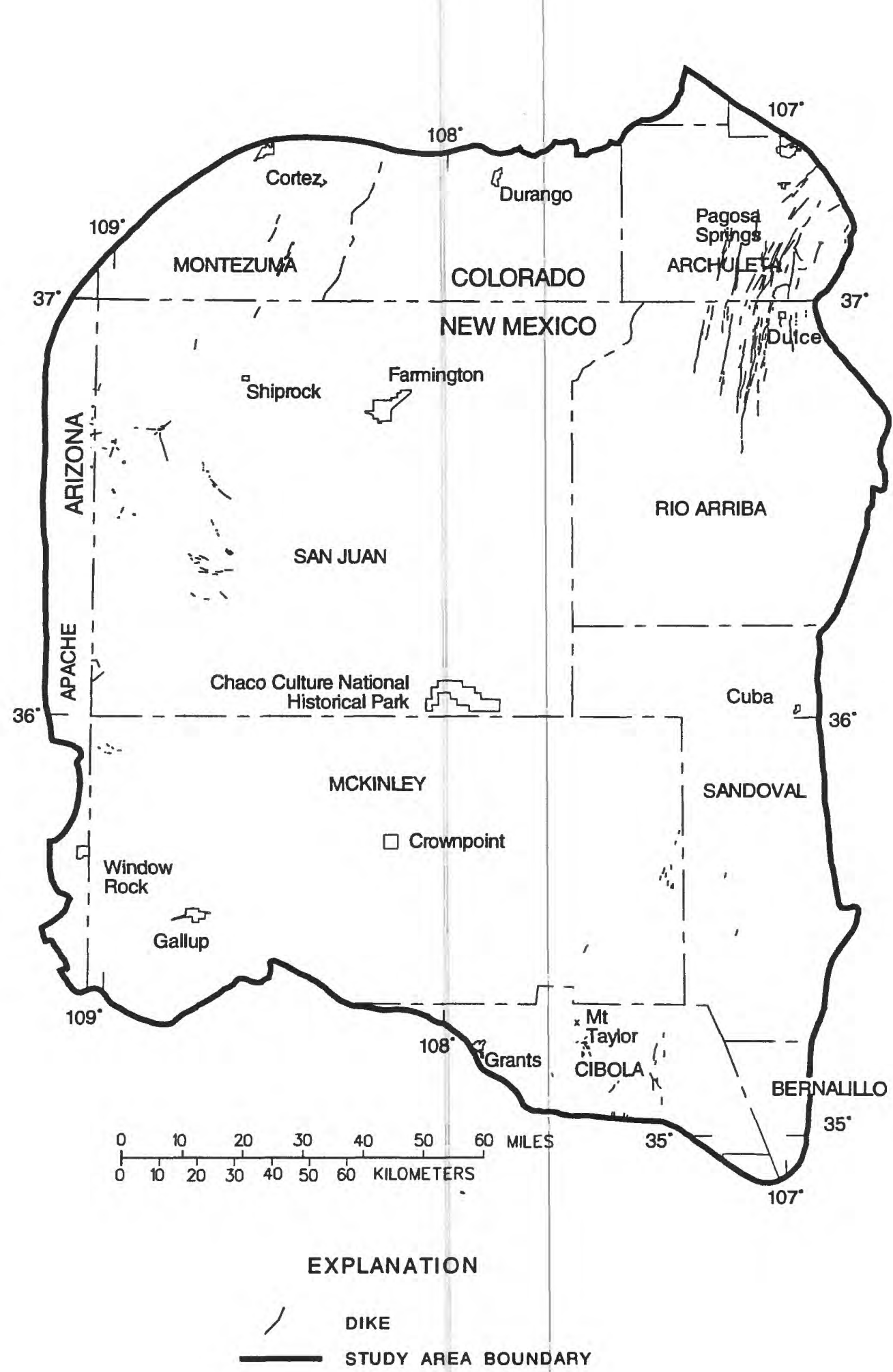

Figure 29.--Location of major dikes in the San Juan Basin. 
An aquifer system's internal geometry and the hydraulic contrasts between aquifers and confining units also govern ground-water flow. Hydrogeologic sections, such as that shown in figure 6 (from Stone and others, 1983), illustrate the complex flow patterns that can result from thinning and pinch-outs of units and contrasts in hydraulic conductivity. The geometry of the major hydrostratigraphic units in the basin has previously been discussed.

\section{Outcrop Area Boundaries}

Various boundary types exist within the outcrop area of an aquifer. These include aquifer interaction with surface-water bodies and (or) associated alluvial deposits, recharge infiltrating from precipitation, and evapotranspiration. Surface-water interaction at the outcrop may be either a source of water to the aquifer or a discharge from it, depending on the relative difference in hydraulic head.

\section{Surface-Water Boundaries}

Surface-water bodies such as streams, lakes, and reservoirs directly influence an aquifer in its outcrop area. Streams and reservoirs may either gain water from or lose water to the aquifer. Generally in the higher altitude parts of the basin streams lose water to aquifers and in the lower altitude parts the streams and valley alluvium gain water. In either gaining or losing situations the quantities of water relative to surface flow usually are too small to detect locally.

Most tributaries to the San Juan River that originate at high altitude (more than 7,500 feet above sea level) have perennial flow. These streams and their tributaries lose water to aquifers in their higher reaches, especially in areas including and northeast of the Hogback Monocline. Other areas where stream-channel recharge might be expected are along the Nutria and Defiance Monoclines and along the northern flank of the Zuni Uplift (fig. 4).

Stream and river reaches that probably gain water from the ground-water system include the lower reaches of the San Juan River and its southern tributaries (Chaco River and Cañon Largo) and parts of the Puerco River, Rio Puerco, and Rio San Jose (fig. 11). Also, although ground water may discharge to the surface in these drainage systems they might not actually contribute to surface-water flow; in many instances the ground-water discharge is entirely consumed by evapotranspiration before it can migrate through valley-fill alluvium to reach the stream channel.

\section{Recharge from Precipitation}

Recharge from precipitation is a boundary type that contributes water to the aquifer system. This distributed recharge on the area of aquifer outcrop is the residual from total precipitation after losses to evapotranspiration and surface runoff. Direct ground-water recharge from precipitation was estimated using the approach documented in Hearne and Dewey (1988) and Waltemeyer and Kernodle (1992). The technique uses multiple regression analyses to establish relations between precipitation and selected basin characteristics to predict runoff. An initial assumption is that all net recharge is due exclusively to winter precipitation. Estimated sublimation and evaporation are then subtracted from the difference between total precipitation and total runoff to obtain an estimate of direct recharge on the aquifer outcrop. 
Regression equations were developed for three altitude-precipitation regimes in the study area. The first regime includes basins where the area-weighted mean basin altitude is greater than 7,500 feet above sea level. Data from nine jnstrumented drainage basins in the San Juan Mountains (fig. 30) were used in the regression analysis to determine the rainfall-runoff relation for this regime. Mean winter precipitation and drainage area were found to describe mean winter runoff with a standard error of estimate of 13 percent. The second regime includes basins where area-weighted mean basin altitude is less than 7,500 feet above sea level and area-weighted mean winter precipitation is less than 12 inches. The third regime includes basins where area-weighted mean basin altitude is less than 7,500 feet above sea level and area-weighted mean winter precipitation is greater than 12 inches. Rainfall-runoff relations for the latter two regimes were developed using the basins that Hearne and Dewey $(1988$, p. 32,37$)$ used in their rainfall-runoff relations for the Taos Plateau (mean winter precipitation less than 12 inches) and the Sangre de Cristo Mountains (mean winter precipitation greater than 12 inches). Basin area and areaweighted mean winter precipitation were recalculated from the values used by Hearne and Dewey (1988). The study area then was divided into 320 drainage basins and mean winter discharge was computed for each using the equation appropriate for each basin's altitude and amount of precipitation. The areas in the San Juan Basin for which the following equations were developed are shown in figure 31.

For basins having an area-weighted mean basin altitude greater than 7,500 feet above sea level (derived for the San Juan Mountains region), the following equation was derived to define winter runoff:

$$
\mathrm{QS}=0.10632 \times \mathrm{AREA}^{(0.868)} \times \operatorname{PRECIP}^{(0.977)}
$$

where QS is mean winter runoff, in cubic feet per second;

AREA is drainage basin area, in square miles; and

PRECIP is area-weighted mean winter precipitation for the period 1931-60, in inches.

For basins having an area-weighted mean basin altitude less than 7,500 feet and an area-weighted mean winter precipitation less than 12 inches (derived for the Taos Plateau region), the regression equation was found to be:

$$
\mathrm{QS}=0.00002188 \times \mathrm{AREA}^{(1.05)} \times \mathrm{PRECIP}^{(4.03)} .
$$




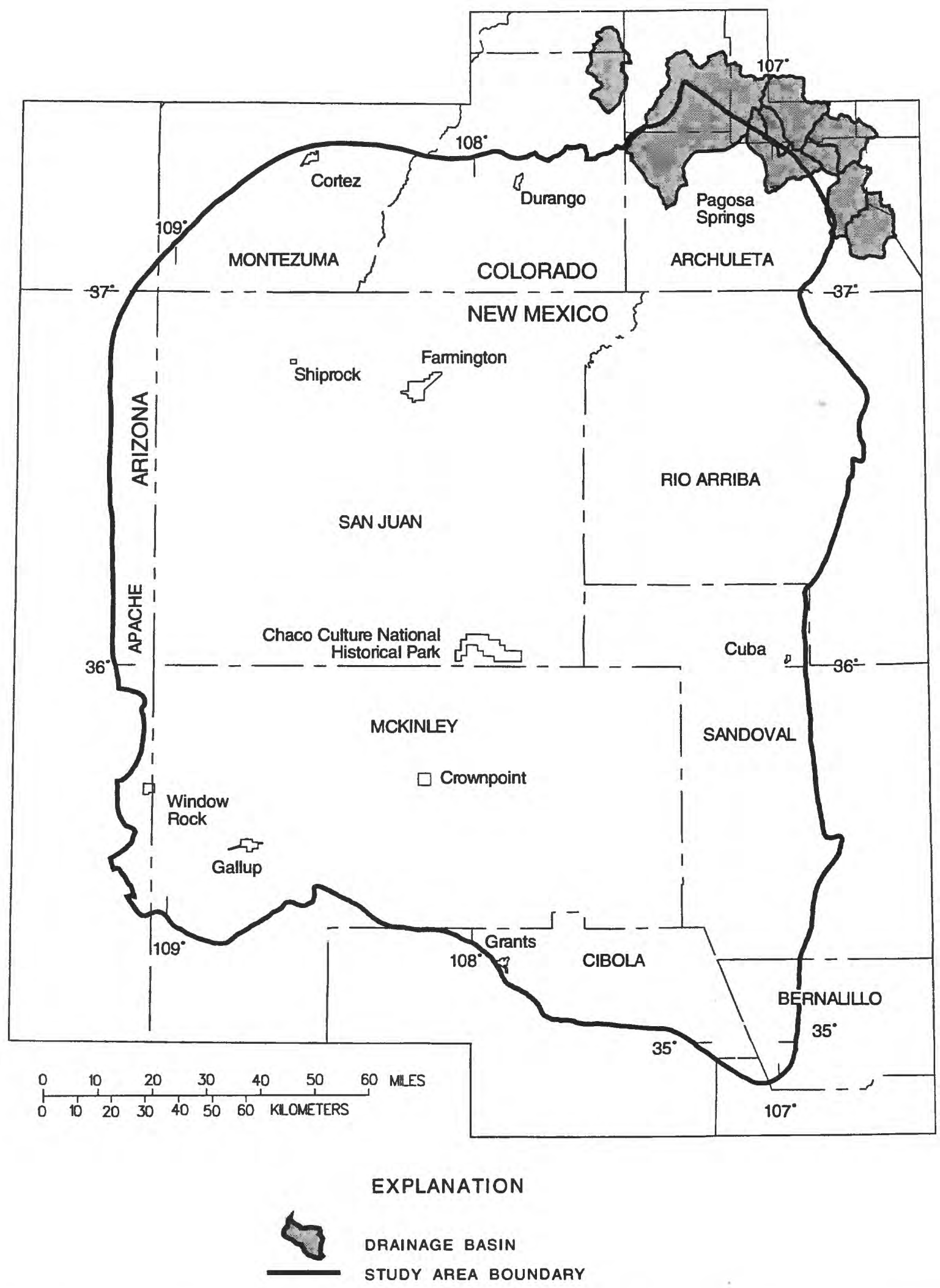

Figure 30.--Location of drainage basins used to determine the rainfall-altitude-runoff relation for the San Juan Mountains. 


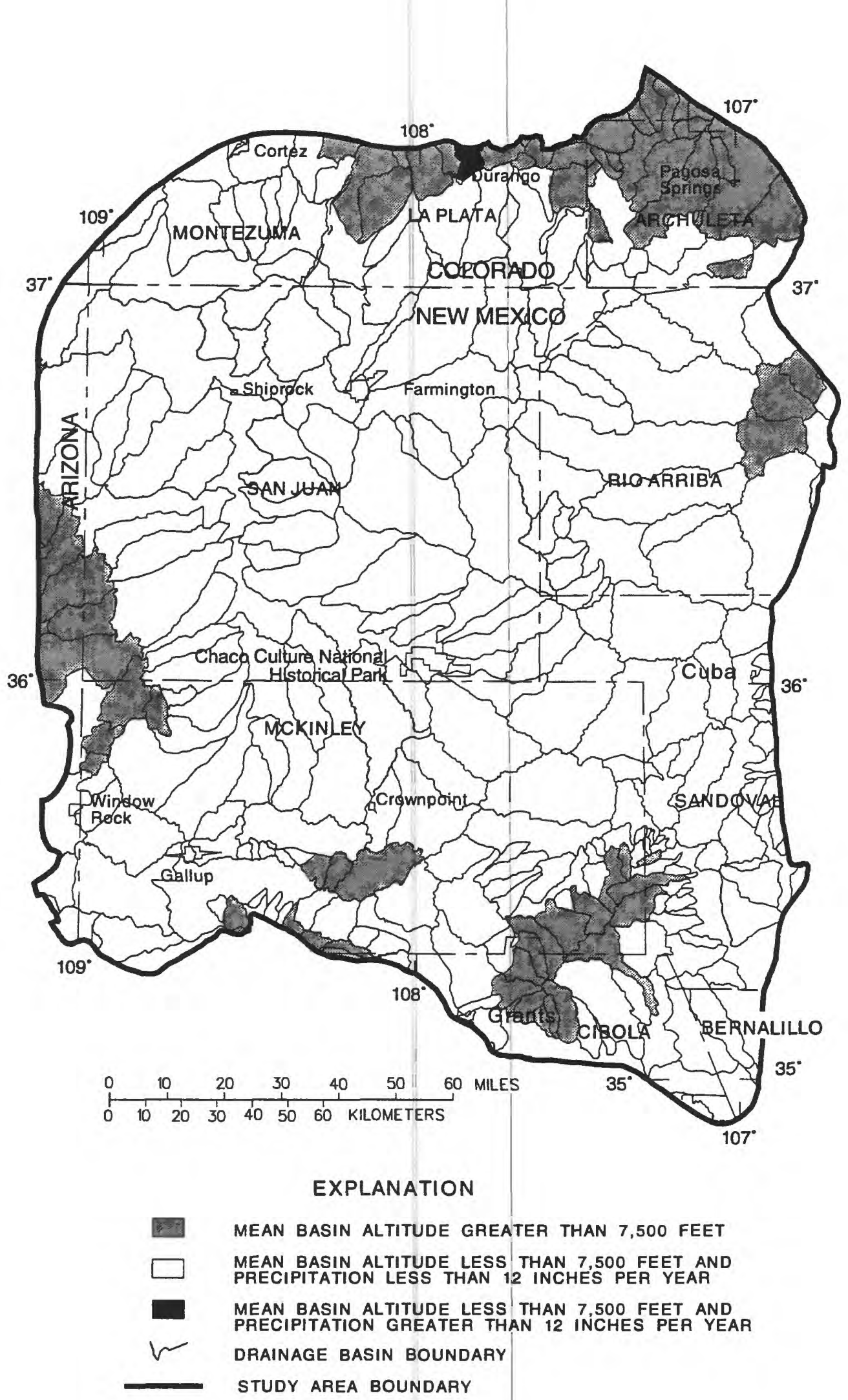

Figure 31.--Surface-water drainage basins and the division of the San Juan Basin into three rainfall-runoff regimes. 
For basins having an area-weighted mean basin altitude less than 7,500 feet and an area-weighted mean winter precipitation more than 12 inches (derived for the Sangre de Cristo Mountains region), the regression equation was found to be:

$$
\mathrm{QS}=0.00008318 \times \mathrm{AREA}^{(0.972)} \times \operatorname{PRECIP}^{(3.57)} \text {. }
$$

Sublimation and evaporation were then estimated using the equation:

$$
\mathrm{QET}=5200500 \times \mathrm{AREA} \times \mathrm{ALT}^{(-1.89)}
$$

where QET is the estimated evaporation and sublimation, in cubic feet per second; and

ALT is the area-weighted mean basin altitude, in feet above sea level.

Finally, estimated direct recharge was computed as the residual of total precipitation minus runoff, sublimation, and evaporation.

Some ranges of estimated direct recharge for the drainage basins are shown in figure 32 . The several large areas of virtually no recharge shown in figure 32 coincide with most of the highaltitude areas of the basin. These are areas where the sublimation, evaporation, and runoff components of the surface-water budget are large and the recharge, which is computed as the residual, has the greatest error potential. The estimated rate ranges from 0 to 0.15 inch per year and the area-weighted average for the basin is 0.10 inch per year. A calculated recharge rate of 0.1 inch per year for a drainage basin east of Grants, New Mexico, was reported by the U.S. Department of the Interior (1986, p. 2-53). The combined recharge rate for the entire basin is equivalent to a steady flow of about 150 cubic feet per second.

In the computations, the mechanism of the direct recharge is not restrained. The recharge could be uniformly distributed throughout the drainage basin, concentrated more on the rechargereceptive outcrop areas, or could be channel loss from streams as they cross outcrops. For simulation purposes, however, the recharge was assumed to be restricted to and distributed over the area of outcrop of the aquifers.

The current climate in the basin probably has little influence on the long-term rates of recharge to or discharge from the aquifers in the basin. Preliminary age estimates for water in the Morrison Formation near the center of the basin place the age of the water at about 1.5 million years (Kernodle and Phillip, 1988). Also in the Morrison on the western side of the basin, carbon14 age dating indicates that water has moved only a short distance (generally less than 20 miles) from the outcrop during the approximately 40,000 years that are dateable by the technique. The water is old enough throughout most of the aquifers in the basin to have been affected by pluvial climatic periods during the Pleistocene Epoch. 
Studies have found direct evidence of recharge surges during the Pleistocene (Phillips and others, 1986) or have inferred the surges on the basis of geologic and geomorphic evidence (Watson and Wright, 1963). Phillips and others (1986), using carbon-14 age dating and oxygendeuterium ratios, found evidence of cooler temperatures and greater effective precipitation for a period prior to 20,000 years before the present and again about 17,000 years before the present. Citing other studies of freshwater ostracoda, Phillips and others (1986) noted another pluvial period about 9,000 years before the present.

Watson and Wright (1963) described landslide development on the east flank of the Chuska Mountains in New Mexico. They attributed the three block glide events that they found to periods of high ground-water levels in the Chuska Sandstone. The higher water levels were postulated to correlate with pluvial periods during the Pleistocene. Periods of high water levels in the Chuska Sandstone are significant because the driving head to the underlying aquifers is thereby increased.

Although much of the water in the aquifers in the basin has been shown to be old and added to the ground-water system during wet climatic cycles, pressure changes in an artesian aquifer propagate much faster than the actual movement of a volume of water. Pressure changes can be shown to adjust quickly to changes in discharge (Dam and others, 1990a), and it is likely that the predevelopment (early 20th century) potentiometric heads reflected current or recent historical climatic conditions, whereas the actual flow paths of water in the aquifers reflect paleorecharge conditions.

Although much of the water now in the ground-water system entered in recharge surges, it is important to note that the system is being recharged under current conditions. Peeters (1983) used carbon-14 and tritium methods to date water in the Ojo Alamo Sandstone. She found that waters of a modern carbon-14 age also had post-atomic age elevated tritium, indicating active modern recharge.

\section{Evapotranspiration}

Evapotranspiration acts as a boundary in the ground-water system where water in the zone of saturation is affected by surface processes. This generally happens in areas of ground-water discharge, primarily in the valleys of the gaining streams described previously. Evapotranspiration of ground water is assumed to be zero in areas of great depth to water. As the depth to ground water below land surface decreases, the rate of evapotranspiration of ground water increases (Emery, 1970) until the rate reaches at least the potential annual evaporation (fig. 10). Because this process generally is limited to alluvial-fill stream valleys, however, the contribution of ground water, compared to surface water from the stream, usually cannot be quantitatively determined.

Evapotranspiration is a major component of the overall water budget of the basin. Winter evaporation and sublimation were calculated (eq. 4) to account for 3.4 of the total 6.0 inches of winter precipitation. Basinwide, summer evaporation and transpiration consume virtually all of the remaining 6.3 inches of annual precipitation. Most of this consumptive loss in the basin, in both winter and summer, is by evaporation or sublimation following precipitation and, therefore, is not an element in the ground-water system. 


\section{Subcrop Boundaries}

A subcrop boundary is a special case of both an internal geometric boundary and an outcrop-area boundary. Areas where this specific boundary type occurs in the San Juan Basin are upturned and eroded aquifers in the Defiance Monocline (fig. 4) that subcrop beneath the Chuska Sandstone and Deza Formation (of Wright, 1954). This boundary type will be illustrated later in the section on internal geometric boundaries. As discussed earlier, the elevated hydraulic head in these overlying units drives water into the underlying regional aquifers.

\section{Oil-Water and Gas-Water Interfaces}

Oil and gas are valuable natural resources in the basin, and both are found in abundance in the aquifers described in this report. Several post-Triassic units in the basin produce oil and gas: the Twowells and Paguate Tongues of the Dakota Sandstone, units in the Mesaverde Group, the Pictured Cliffs Sandstone, and coals in the Fruitland Formation.

"Oil and water don't mix" is not totally true in a ground-water system, but the presence of oil or gas in a part of the system does indicate a very stagnant area of ground-water flow. There are two mechanisms of oil entrapment, stratigraphic or structural traps, and an additional mechanism of gas entrapment. The producing oil, gas, and water wells completed in the Gallup Sandstone and transgressive Tocito Sandstone Lentil (fig. 5) are mapped in figure 33, which shows surface expressions of both types of trap. Northeast of the pinch-out of the main body of the Gallup Sandstone (which produces potable water viptually everywhere), the isolated Tocito Sandstone Lentil encapsulated in the Mancos Shale forms stratigraphic traps for oil. The shape of the lenses is clearly outlined by the distribution of producing oil wells. Two clusters of wells producing oil from structural traps are shown (fig. 33) in the southeastern part of the basin. These traps are structural domes where the oil, being lighter than water, rose to displace water and fill the dome.

In both types of traps the presence of oil precludes the flow of freshwater. However, the stratigraphic traps usually are encapsulated in confining units that are very restrictive to any form of fluid flow and the structural traps usually are small in area. A stratigraphic trap is areally restricted to one unit or horizon, whereas a structural trap presents conditions that are favorable for oil or gas production from any suitable unit in the stratigraphic section. 


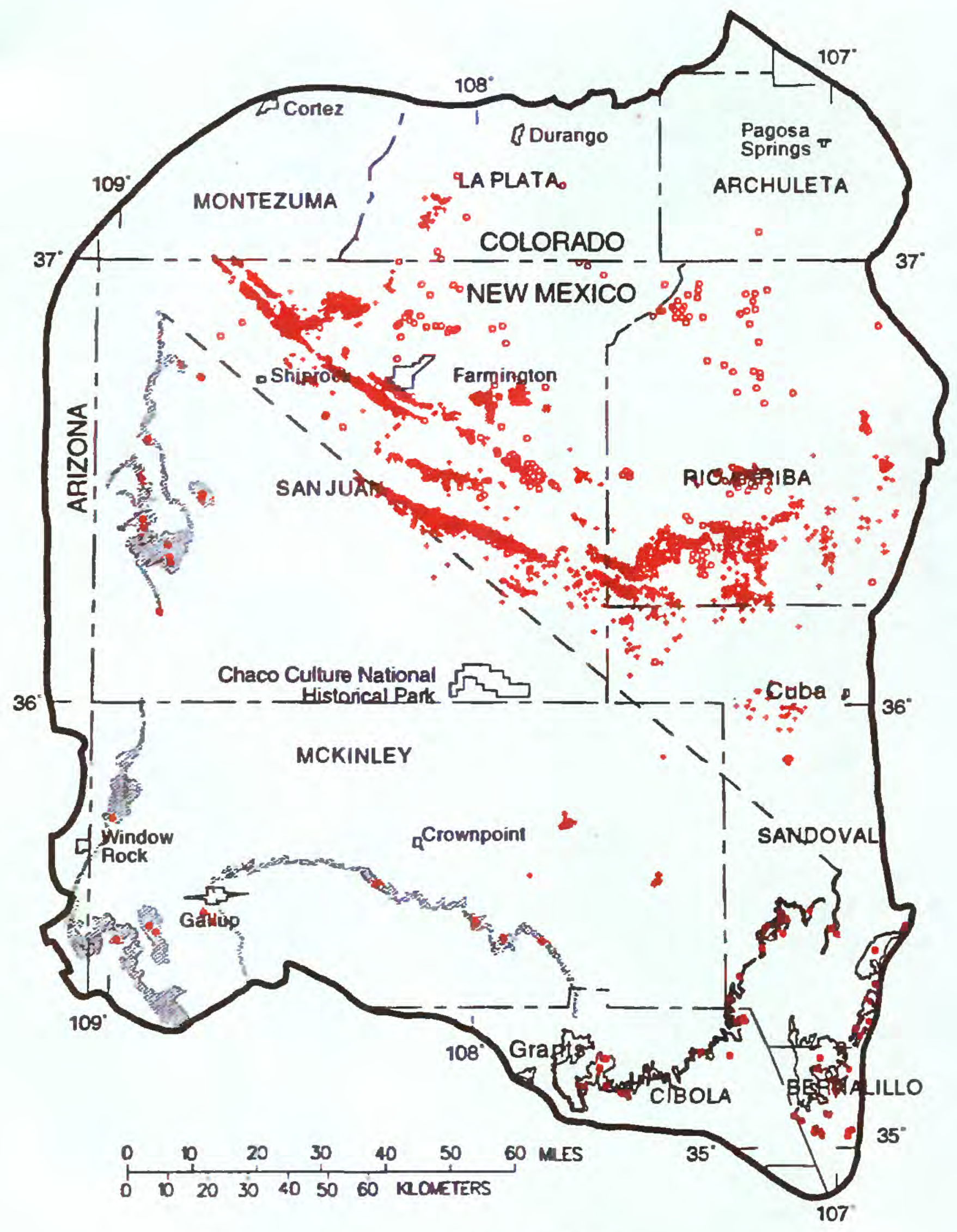

EXPLANATION

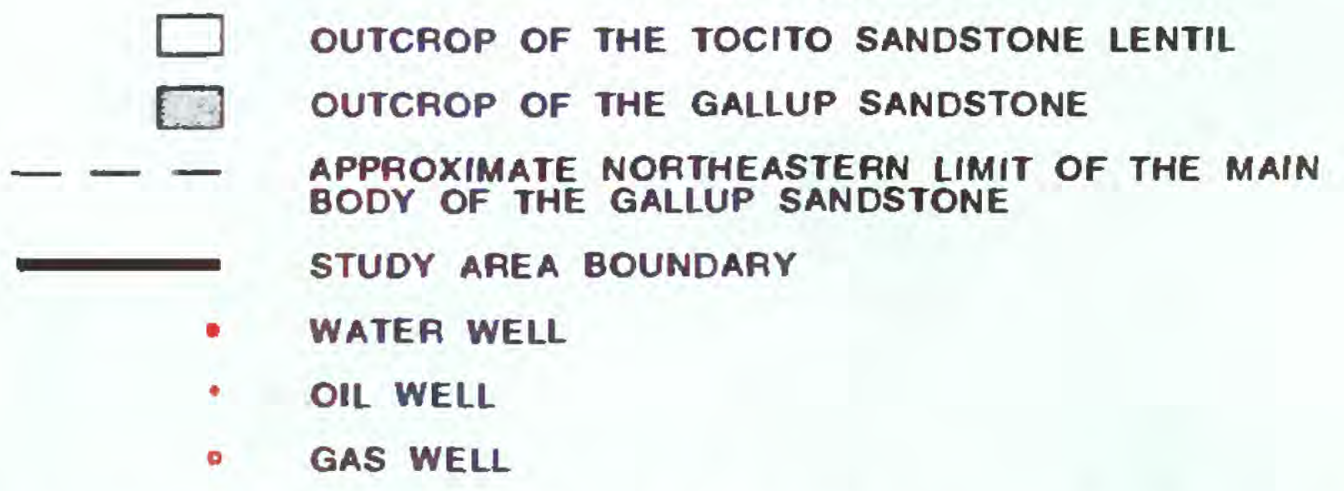

Figure 33.--Location of oil, gas, and water wells completed in the Gallup Sandstone and Tocito Sandstone Lentil. 
Gas may be dissolved in water (the third mechanism). In addition, gas will adsorb and absorb on coal, particularly along cleats and microfractures (Fassett, 1989). Gas occurrence of this nature is characteristic of coal beds in the Fruitland Formation, described earlier. In this instance, the presence of gas does not necessarily preclude the movement of water, but other evidence, primarily water-quality data (Dam and others, 1990b; Kernodle and others, 1990), suggests that water in the Fruitland Formation and underlying Pictured Cliffs Sandstone is dissimilar to water in overlying and underlying units (Thorn and others, 1990a, b) and may be at least partially hydraulically isolated from them.

\section{Density Contrasts}

Fluid density contrasts, if great enough, can be a barrier to ground-water flow. Density is a function of the quantity of dissolved chemicals in the water and, to a much lesser degree, of the temperature of the water. The highest reported density of water from post-Triassic aquifers in the basin is 1.20 grams per cubic centimeter at 20 degrees Celsius (Dwight's ENERGYDATA, Inc., BRIN data base, Oklahoma City, Oklahoma). This water is from a well completed in the Morrison Formation near the confluence of the La Plata River with the San Juan River (fig. 11), northwest of Farmington, New Mexico. The reported dissolved-solids content of the water was 286,900 milligrams per liter, more than eight times that of sea water (Chow, 1964). All other nearby wells completed in the Morrison Formation, the nearest of which is about 3 miles away, have a reported density of 1.06 grams per cubic centimeter or less, indicating that the anomaly is very localized within the Morrison Formation.

The next highest reported density of water from post-Triassic aquifers is 1.069 grams per cubic centimeter at 20 degrees Celsius (91,500 milligrams per liter dissolved solids) for water from the Dakota Sandstone, within 9 miles of the Morrison well cited above. The density of water in the Dakota Sandstone also rapidly decreases away from this well; each aquifer seems to have its own relatively stagnant zone in the Farmington area.

If the local density gradient is high enough, water of this density will affect the movement of water within the ground-water-flow system (Davies, 1989). It is doubtful that geochemical differences in host-rock and water interactions over the short distance observed here created the sharp density gradients that exist today in the same general area for several different aquifers. Therefore, it is reasonable to assume that conditions of long-term flow stagnation led to the observed density anomalies.

\section{DESCRIPTION OF THE MODEL}

The ground-water-flow model completed for this investigation simulated steady-state or predevelopment conditions. Transient simulations were not attempted because of the virtual absence of historical ground-water discharge data. Most urban public-supply systems and mining operations that use or used ground-water supplies were able to provide good withdrawal records. However, the vast majority of ground-water discharges in the basin are from free-flowing, unmetered wells that are often completed in several aquifers. No records exist for changes in discharge from these wells over time. Frenzel (1982) encountered the same lack of ground-water withdrawal data and also limited his model of the basin to a steady-state simulation. Investigators constructing ground-water-flow models of other basins in New Mexico have encountered similar problems and chose to adjust simulated withdrawals until a transient calibration of 
potentiometric-head changes was obtained. Examples of these models are documented by O'Brien and Stone (1983), Hearne (1985), and Hearne and Dewey (1988). A summary of the various approaches to modeling, including a choice of parameters to alter during calibration, was compiled for basins in the Rio Grande Rift by Kernodle (1992).

The model of Kernodle and Philip (1988) was a precursor to this effort. That model was used to determine flow paths and times of travel for steady-state flow conditions in the Morrison Formation and Dakota and Gallup Sandstones. This information was then used by Dam (1995) to select appropriate analytical methodologies for isotope age dating of formation water. Travel times determined from the model agree very well with the isotopic age determinations of Dam, and computed potentiometric heads agree well with the results of Frenzel (1982) and of this model.

\section{Elow Equation. Assumed Conditions, and Computer Programs}

The computer code used to complete the ground-water-flow model of the San Juan Basin is the modular, three-dimensional, finite-difference code documented by McDonald and Harbaugh (1988). The equation that describes three-dimensional flow (Trescott, 1975; McDonald and Harbaugh, 1988) may be written as:

$$
\frac{\partial}{\partial x}\left(K_{\mathrm{xx}} \frac{\partial h}{\partial x}\right)+\frac{\partial}{\partial y}\left(K_{\mathrm{yy}} \frac{\partial h}{\partial y}\right)+\frac{\partial}{\partial z}\left(K_{\mathrm{zz}} \frac{\partial h}{\partial z}\right)-W=S_{s} \frac{\partial h}{\partial t}
$$

where $K_{\mathrm{xx}}, K_{\mathrm{yy}}$, and $K_{\mathrm{zz}}$ are values of hydraulic conductivity along the $\mathrm{x}, \mathrm{y}$, and $\mathrm{z}$ coordinate axes $(\mathrm{L} / \mathrm{t})$;

$h$ is the potentiometric head $(\mathrm{L})$;

$W$ is a volumetric flux per unit volume and represents sources and (or) sinks of water (1/t);

$S_{S}$ is the specific storage of the porous material (1/L); and

$t$ is time ( $\mathrm{t}$ ).

Because the simulation is of steady-state conditions, potentiometric head and storage do not change with time and the right side of equation 5 is equal to zero.

Analytical solutions of equation 5 are possible for only the simplest of hydraulic problems. One approach to obtaining solutions for the typical flow problem is the finite-difference numerical method whereby the area of the aquifer being analyzed is divided into a regular network of horizontal and vertical orthorhombic cells. A set of flow equations is written to describe flow into and out of each cell, then the equations are solved simultaneously by one of several algorithms. The numerical algorithm used in this investigation is the Strongly Implicit Procedure (SIP) documented in McDonald and Harbaugh (1988, chap. 12). The finite-difference numerical method is based on a number of assumed conditions for the flow system: (1) all hydraulic properties of the simulated hydrostratigraphic unit are uniform (homogeneous) within each cell; (2) any anisotropy of hydraulic conductivity is aligned with the principal axes of the finitedifference grid; and (3) the properties of the fluid are uniform in space and constant with time. 
A planimetric view of the finite-difference model grid that was used to discretize components of the properties of the simulated aquifers is shown in figure 34 . The grid has 100 rows of cells, each 3,000 meters in spacing, and 100 columns of cells, each 3,070 meters in spacing. The entire grid is rotated 46 degrees counterclockwise to conform to a general overall shoreline axis of orientation that prevailed during the transgressions and regressions of the Cretaceous seas.

The planimetric view in figure 34 shows the grid in a Universal Transverse Mercator (zone 12) map projection. The initial orthorhombic grid was projected to this map coordinate system to match the map coordinate rotation and distortion of the spatial data used in the construction of the model. Although the amount of distortion would be relatively minor over a small area it becomes significant (hundreds of feet) for grids that span areas as large as the San Juan Basin. Figure $\mathbf{3 5}$ is an oblique areal view of the study area and finite-difference grid as they would appear from a vantage point about 30 miles above the Earth's surface. The figure illustrates the need to form the grid to match the map projection that is used to portray the Earth's surface.

The finite-difference grid is stacked 12 layers deep to represent the major aquifers and confining units in the basin. Figure 36 is a diagram that correlates the previously described hydrostratigraphic units with the finite-difference layers employed in the model. Not all units were explicitly simulated; an entry of "VK" in the diagram indicates that the unit was implicitly simulated using a computed vertical harmonic leakance between finite-difference layers.

A geographic information system (GIS) was used to store, manipulate, analyze, and extract the spatial hydrogeologic data that were used to construct the ground-water-flow model of the San Juan Basin. (The GIS also was used to prepare the map figures in this report.) An introductory explanation of the techniques and procedures of using the GIS in support of the ground-waterflow model may be found in Kernodle and Philip (1988). For readers who would like additional information on the functionality of a GIS, Robinove (1986) authored a concise presentation on the "Principles of logic and the use of digital geographic information systems."

\section{Representation of Boundaries}

Distributed recharge from precipitation, stream-aquifer interaction, changes in hydraulic properties, aquifer geometry, and subcrop boundaries were simulated in the steady-state groundwater-flow model of the San Juan Basin. Evapotranspiration, minor faults, dikes, oil-water/gaswater interfaces, and density contrasts were not simulated. Evapotranspiration in areas of aquifer outcrop was incorporated into the computed net rate of recharge and therefore was simulated indirectly. Evapotranspiration in areas of ground-water discharge, coincident with alluvial valleys of major streams, was assumed to be represented by the stream boundary. Minor faults and dikes were not considered to be a significant influence on ground-water flow. Oil and gas were not thought to greatly influence ground-water flow because their occurrence largely is limited to disconnected stratigraphic traps encapsulated in major confining units. Finally, density contrasts were not simulated because the areal extent of high-density water is small, its occurrence coincides with areas of hydraulic stagnation, and the computational resources needed to simulate this boundary condition for only a minor part of the aquifer system could not be justified for this investigation. 


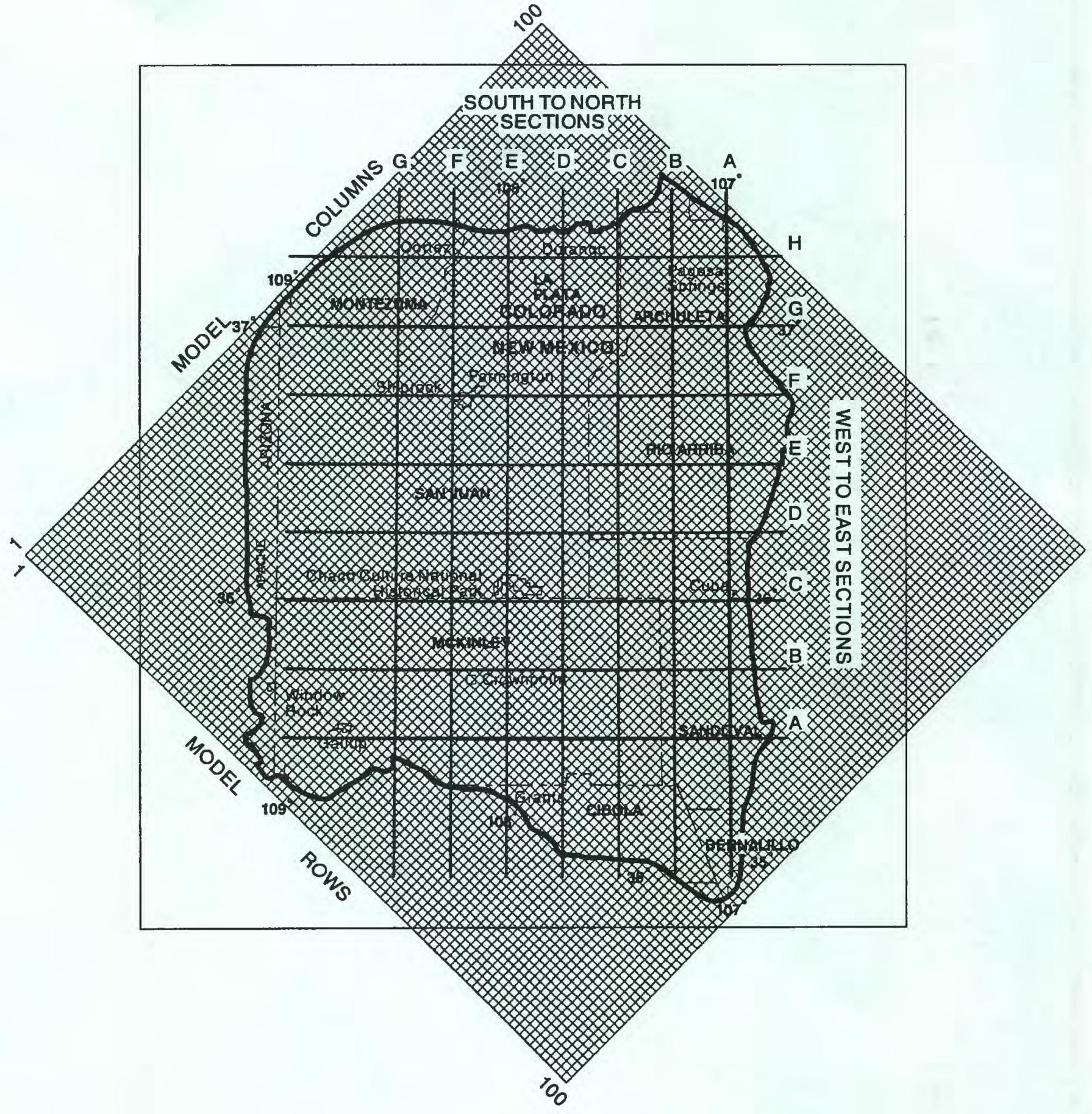

Figure 34.--Finite-difference model grid and locations of hydrogeologic sections shown in figures 37 and 38 . 

EXPLANATION

AQUIFER

CONFINING UNIT

NOT SIMULATED

VK-Implicitly simulated using a computed vertical harmonic leakance

\begin{tabular}{|c|c|}
\hline San Jose Formation & 1 \\
\hline Animas and Nacimiento Formations & 2 \\
\hline Ojo Alamo Sandstone & \multirow{3}{*}{3} \\
\hline Kirtland Shale \& & \\
\hline Fruitland Formation & \\
\hline Pictured Cliffs Sandstone & 4 \\
\hline Lewis Shale & 5 \\
\hline Cliff House Sandstone and La Ventana Tongue & 6 \\
\hline Menefee Formation & 7 \\
\hline Point Lookout Sandstone & 8 \\
\hline Hosta Tongue & \multirow{3}{*}{ VK } \\
\hline Crevasse Canyon Formation & \\
\hline Upper Mancos Shale & \\
\hline Gallup Sandstone $\quad \sum$ Mancos Shale & 9 \\
\hline Lower Mancos Shale: & VK \\
\hline Dakota Sandstone & 10 \\
\hline Morrison Formation & 11 \\
\hline Wanakah Formation & VK \\
\hline Entrada Sandstone & 12 \\
\hline Chinle Formation & \\
\hline
\end{tabular}

Figure 36.--Correlation of geologic units and model layers. 


\section{Distributed Recharge from Precipitation}

Distributed recharge from precipitation was simulated as a flux of water introduced to the model cells containing an outcrop of the unit represented by the cell's layer. By using GIS, the model grid was overlaid on a digital map of the aquifer outcrop so that the area of outcrop of each aquifer within each cell could be determined. That information layer was then overlaid on a digital map depicting the rate of recharge so that the rates for each area of outcrop within each model cell could be determined. The net flux to the aquifer for each model cell was then computed as the sum of outcrop areas multiplied by the recharge rate for that area. The entire process was repeated for the outcrop of each of the 12 units represented in the model.

\section{Stream-Aquifer Interaction}

The interaction between surface-water bodies and the ground-water system was simulated as a head-dependent flux boundary with limitations placed on the maximum possible surfacewater loss (McDonald and Harbaugh, 1988, chap. 6). The flow rate to or from the aquifer is a function of the hydraulic-head difference between the aquifer and the surface-water body, the area (or length times width) of the surface-water body, and the hydraulic conductivity and thickness of the streambed material:

$$
\mathrm{QRIV}=(\text { HRIV }- \text { h }) \mathrm{KL} \mathrm{W} / \mathrm{M}
$$

where QRIV is the flux to or from the surface-water body $\left(\mathrm{L}^{3} / \mathrm{t}\right)$;

HRIV is the representative altitude of the stream surface (L);

h is the model-computed ground-water head (L);

$\mathrm{K}$ is the hydraulic conductivity of the streambed material $(\mathrm{L} / \mathrm{t})$;

$\mathrm{L}$ is the total stream length in a model cell (L);

$\mathrm{W}$ is the representative width of streams within a model cell $(\mathrm{L})$; and

$M$ is the thickness of streambed material (L).

The part of the equation that remains constant for each model cell (K L W / M) is referred to as the streambed conductance. Streambed conductance was computed for each cell that contained both aquifer outcrop and a stream segment. The stream network used in the model simulation is the one shown in figure 11. The main stems of the San Juan River, Chaco River, Rio Puerco, and Rio San Jose were assigned a width of 200 feet. All other segments were assigned a width of 100 feet. Some of the larger surface-water features (lakes, reservoirs, and the San Juan River downstream from Navajo Reservoir) were represented as polygon features, eliminating the need to estimate channel width. The bed thickness for all streams was arbitrarily assumed to be 1 foot and the hydraulic conductivity of the bed material was assumed to be 20 feet per day.

In a process similar to the one described for recharge, a series of overlays was performed to arrive at a total stream area for the outcrop of each hydrostratigraphic unit within each model cell. This area was then multiplied by the hydraulic conductivity to determine the streambed conductance for each cell. 
The stream-surface altitude (HRIV) was obtained by using the GIS to extract altitude data from a continuous-surface representation of topography for vertices along the lines that define the streams. The altitude data were obtained from 1:250,000-scale digital elevation models that have a vertical accuracy of 30 meters (U.S. Geological Survey, 1987). The altitudes of the vertices were then averaged for the outcrop of each hydrostratigraphic unit within a model cell to obtain a mean channel altitude. The term (HRIV - $h$ ) in equation 6 was then limited to a maximum value of 10 feet to place an upper limit on the loss of water from the stream to the aquifer. No limit was placed on ground-water discharge rates to the streams.

\section{Internal Geometric Boundaries}

As stated earlier, the structure-contour maps (figs. 13, 15, 17-25, 28) are derived from computer-generated and human-edited continuous-surface representations of the tops of the major hydrostratigraphic units. The maps were then assimilated into the GIS, published as structurecontour maps in the Hydrologic Investigations Atlas 720 series, and became the data base used in this model to define top and bottom altitudes and aquifer (or confining unit) thicknesses.

Other derivative products from the data bases used to produce the hydrologic atlases are possible, including the layer-definition hydrogeologic sections shown in figures 37 and 38 . These sections were constructed directly from the digital data layers of the altitudes of land surface and the tops of the hydrostratigraphic units. The sections have been corrected to include the earth's curvature and are vertically exaggerated by a factor of 20 . Although these sections represent model layers, they also quantitatively reveal the complex geologic structure of the San Juan Basin from many new vantages not easily obtained without the use of GIS technology.

As stated earlier, these digital data layers were used to define the internal geometry of the 12 hydrostratigraphic units simulated by the model. To do this, an interpolated spot value for the structure altitude of each unit was obtained for the centroid of each model cell.

\section{Subcrop Boundaries}

Several regional aquifers are truncated and overlain by the Chuska Sandstone, Deza Formation, and landslide deposits in the vicinity of the Defiance Monocline. The model representation of these hydrostratigraphic units overlain by the Chuska Sandstone is shown in figure $37 \mathrm{C}, \mathrm{D}$, and $\mathrm{E}$. The regional aquifers are under hydraulic stress from these overlying units. The rate of downward movement of ground water into the Cretaceous units is governed by the differential hydraulic head, the vertical hydraulic conductivity of the units through which the water must pass, and the thickness of those units. A general-head boundary (McDonald and Harbaugh, 1988, chap. 11) is appropriate for simulation of this hydraulic condition. The equation describing flow to or from this numerical boundary type is identical to the equation for a streamaquifer boundary (eq. 6) previously described. The difference between the two numerical boundary types is that there is no limit to the amount of water that an aquifer can gain from a general-head boundary.

The location of the general-head boundary used to simulate the downward movement of water from the Chuska Sandstone, Deza Formation, and landslide deposits into the regional aquifers is shown in figure 39. The position and width of the boundary (about one-quarter mile) are intended to be about the same as those of the subcropping aquifers. The boundary simulated a source of water to the Point Lookout, Gallup, and Dakota Sandstones, Morrison Formation, and Entrada Sandstone. 


\section{EXPLANATION}

HYDROSTRATIGRAPHIC UNITS

Chuska Sandstone
San Jose Formation
Animas and Nacimiento Formations
Kintland Shale, Fruitland Formation,

X

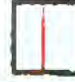

Pictured Cliffs Sandstone

Lewis Shale

Cliff House Sandstone

Menelee Shale

Point Lookout Sandstone

Crevasae Canyon Formation

[ㄱ Gallup Sandstone

MV Mancos Shale

$\Longrightarrow$ Dakota Sandstone

$\square$ Morrison Formation

Danakah Formation and older units

$\sim$ UNCONFORMITY

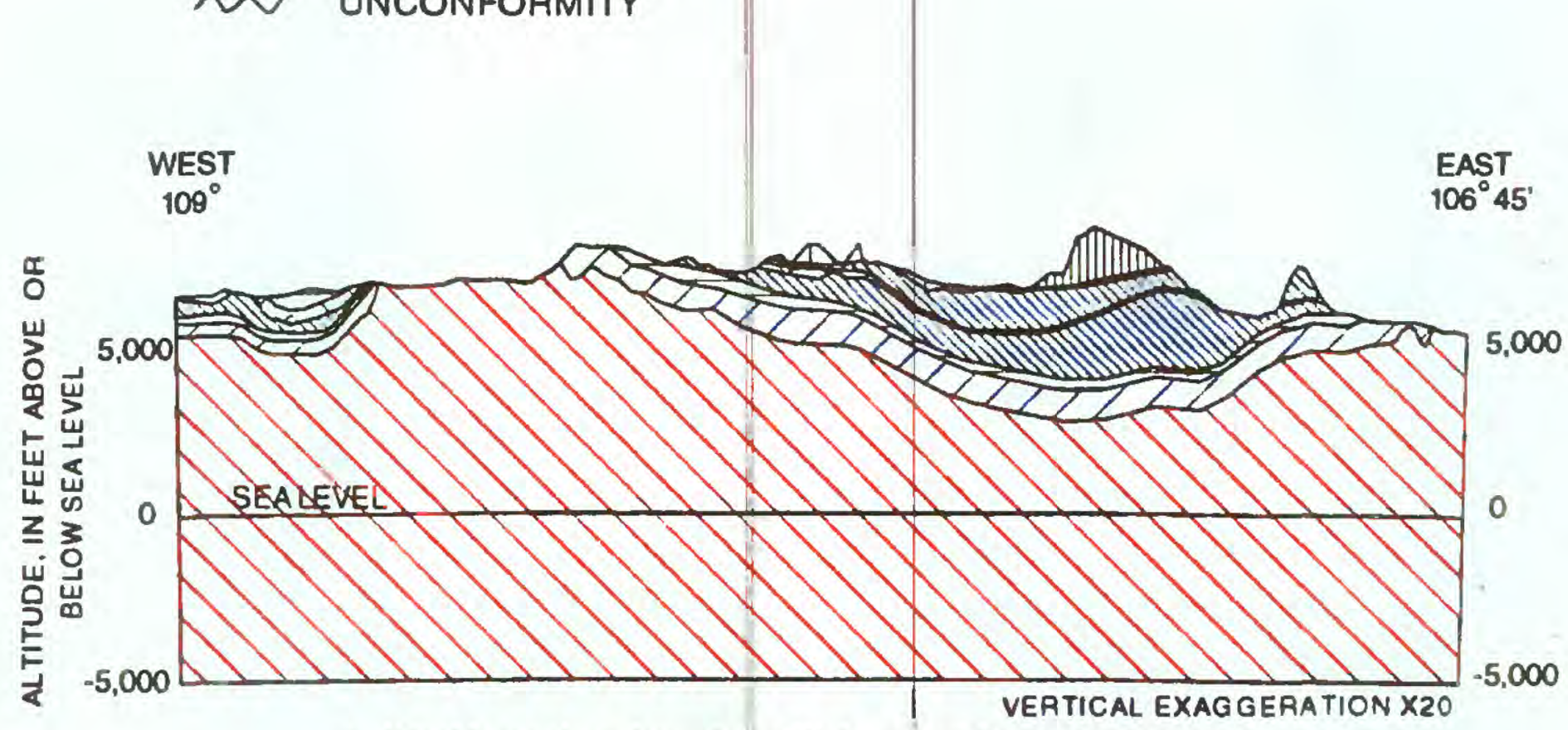

A. West to east section along 35 degrees 30 minutes latitude

Figure 37,--West to east sections showing the vertical layers used in the model. 


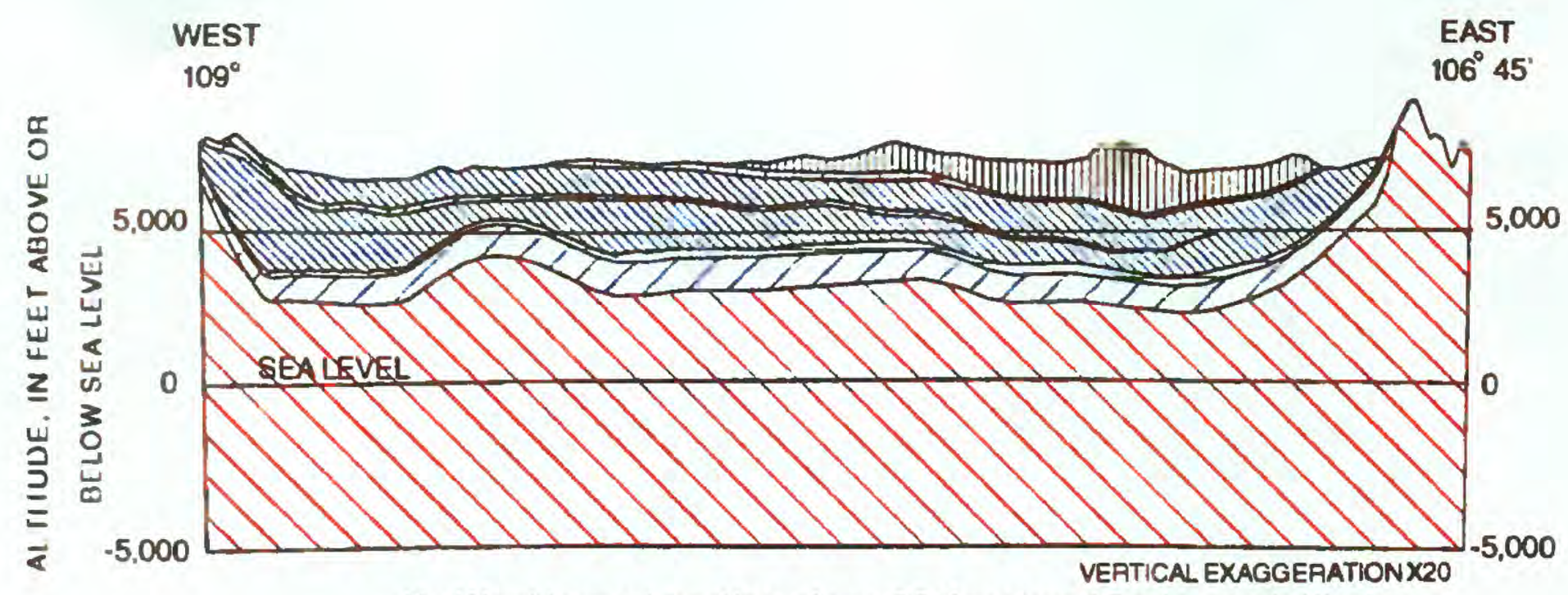

B. West to east section along 35 degrees 45 minutes latitude.
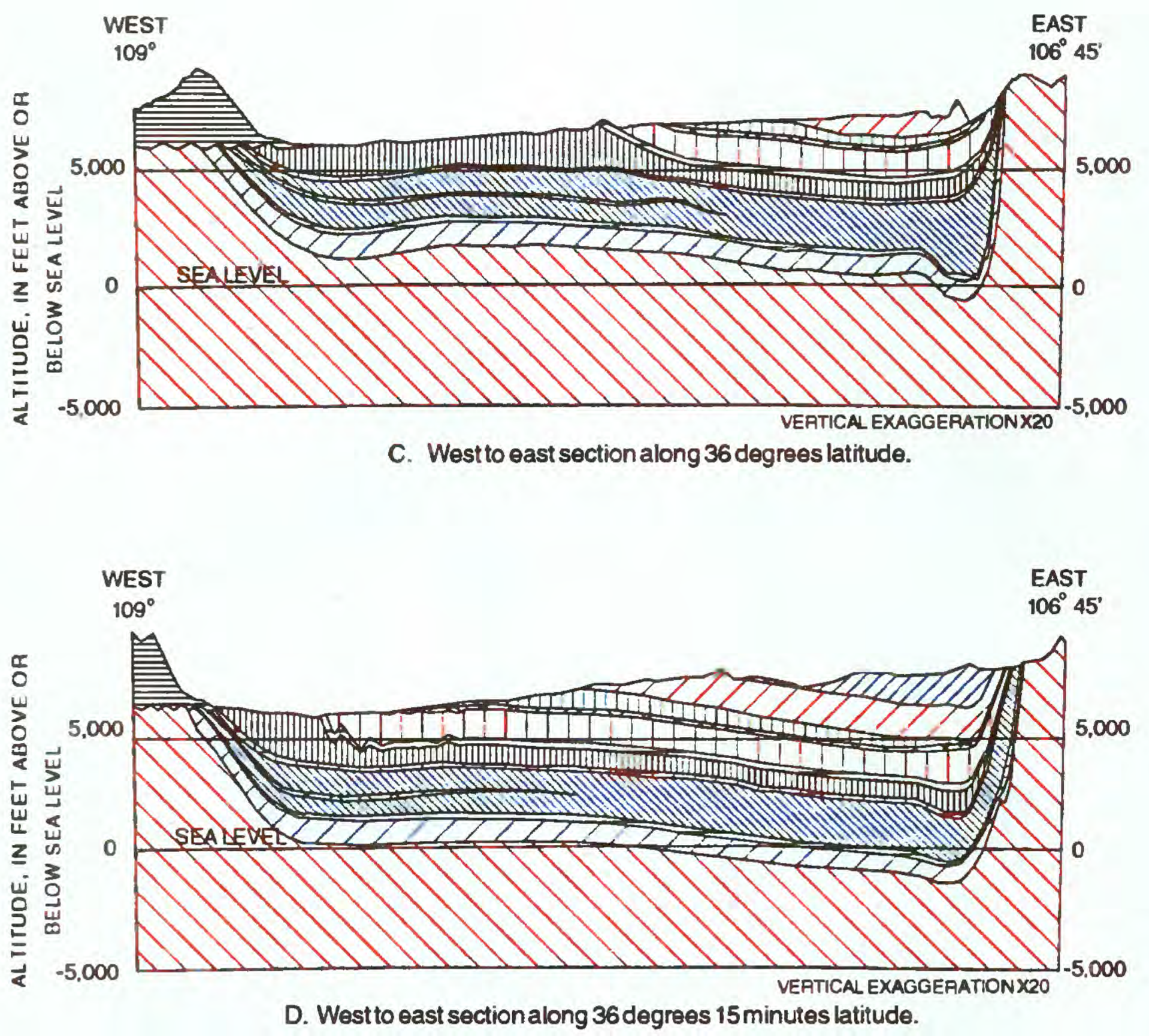

Figure 37.--West to east sections showing the vertical layers used in the model--Continued. 


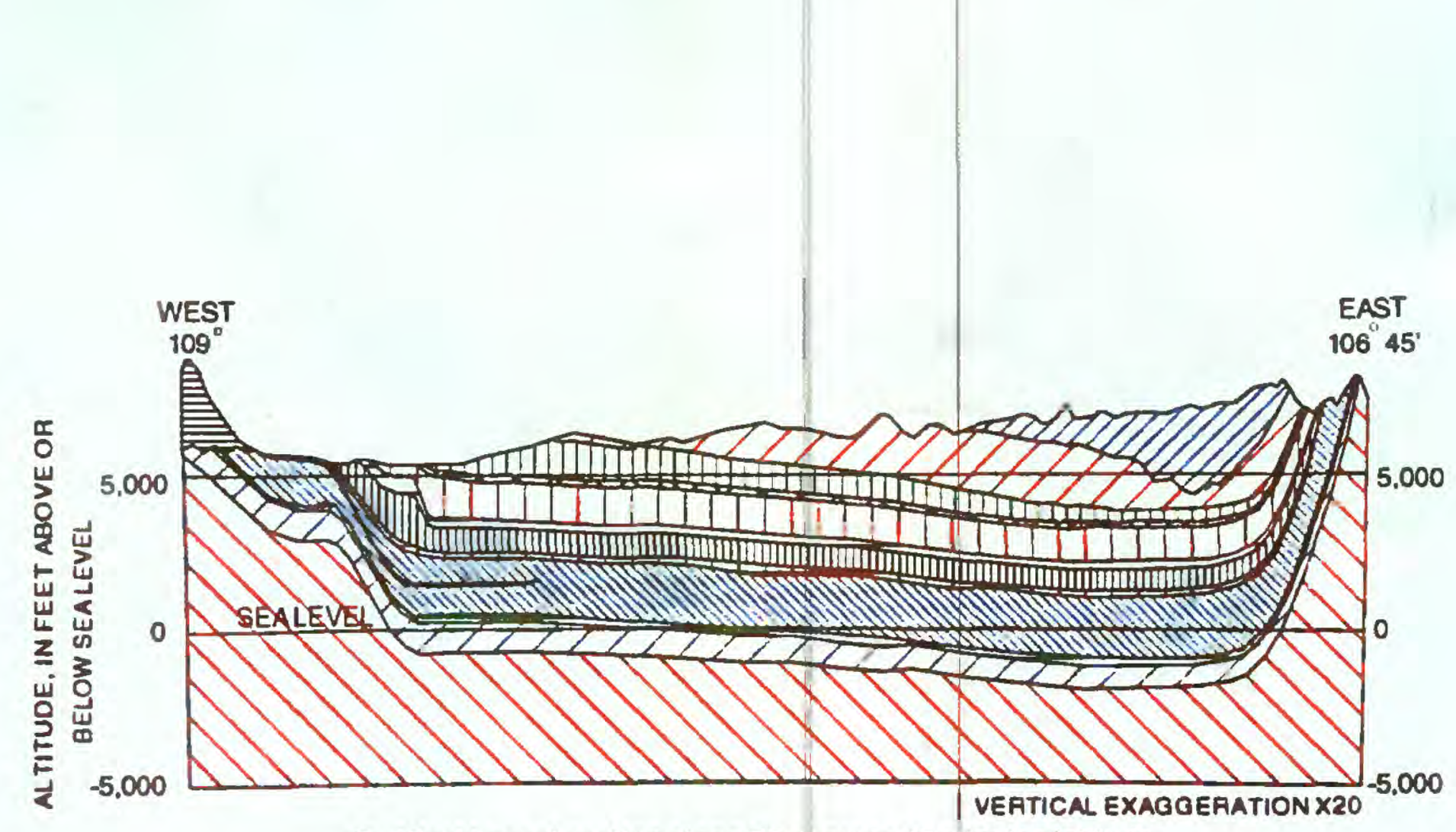

E. West to east section along 36 degrees 15 minutes latitude.
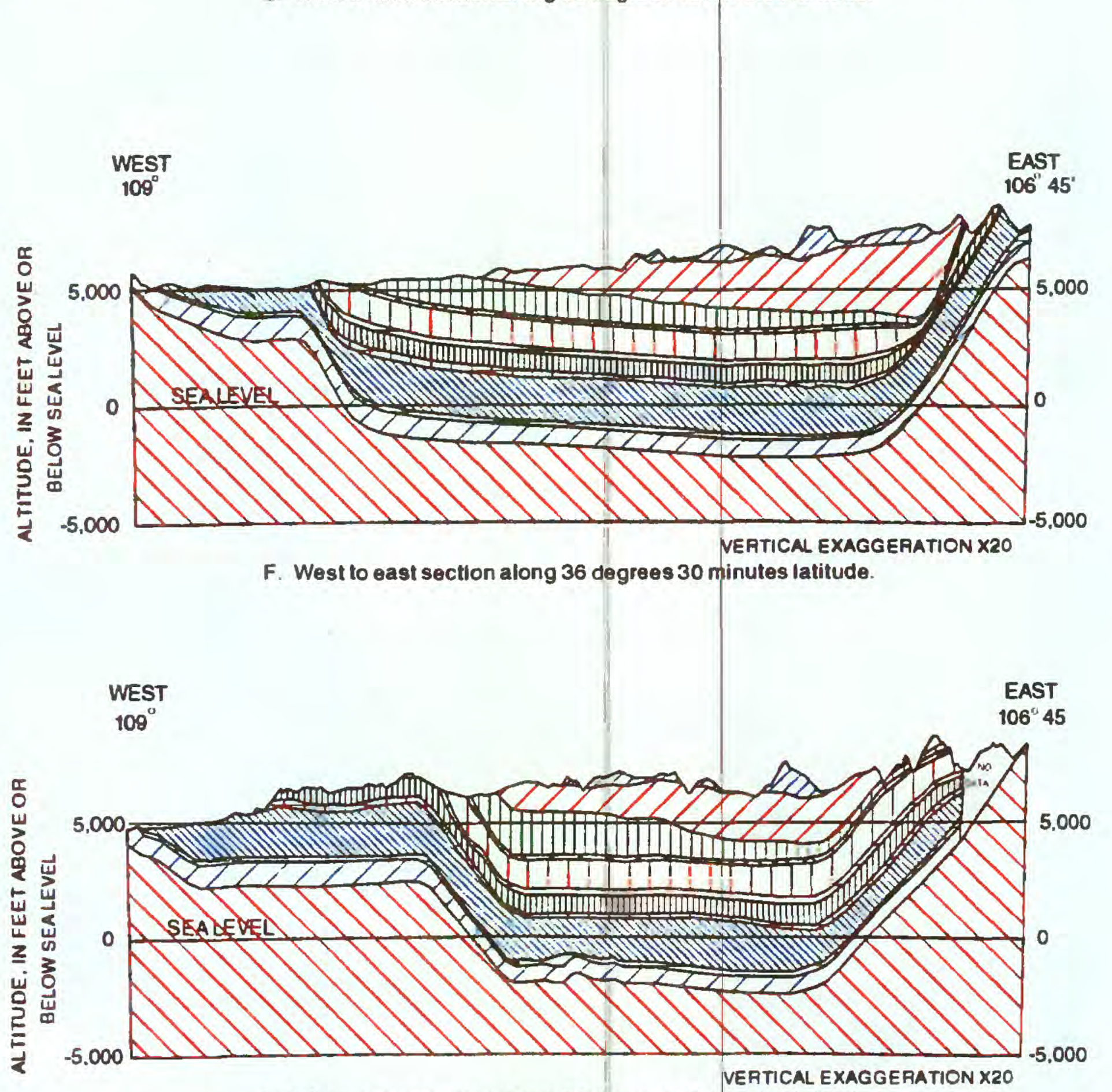

G. West to east section along 36 degrees 45 minutes latitude

Figure 37.--West to east sections showing the vertical layers used in the model--Continued. 


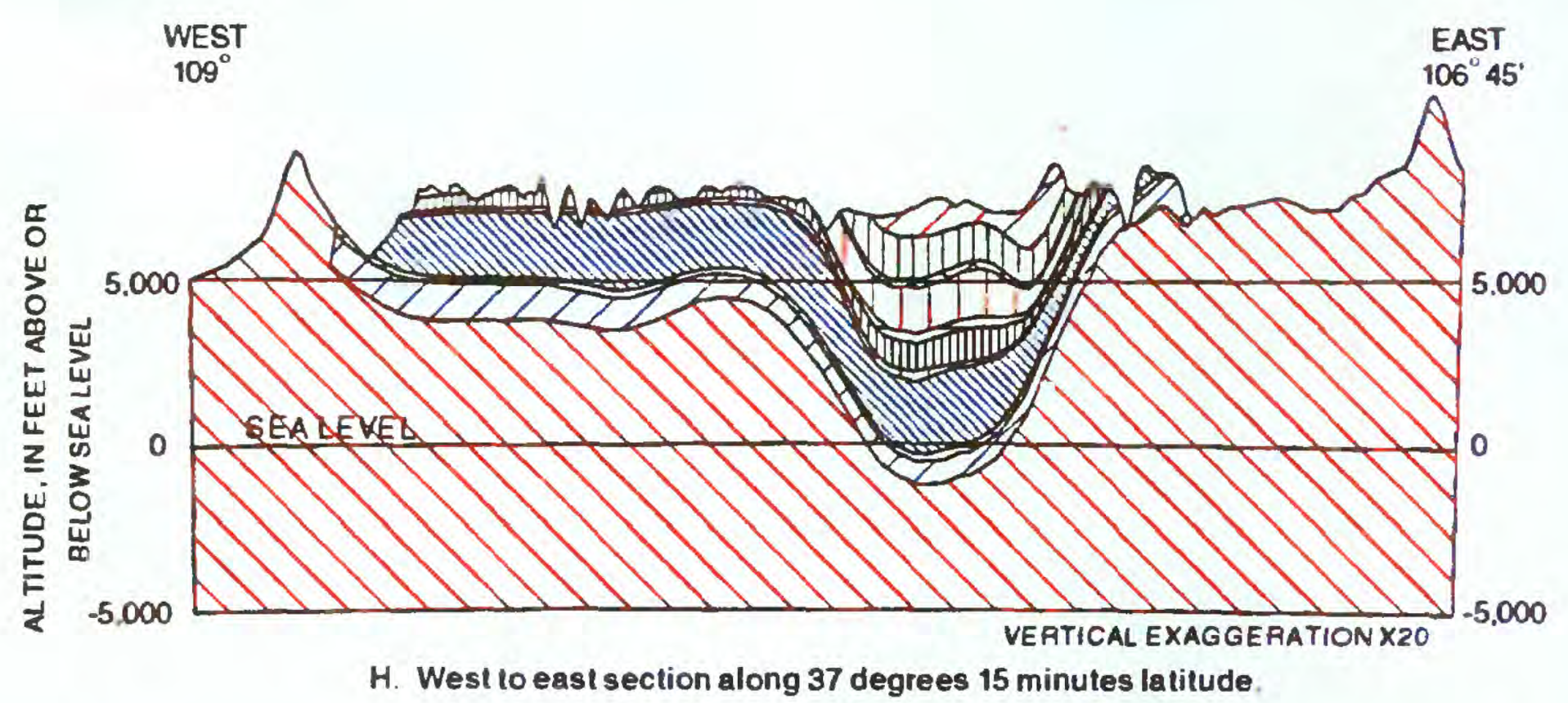

Figure 37.--West to east sections showing the vertical layers used in the model--Concluded.

The eroded surface on which the Chuska Sandstone and Deza Formation rest slopes from about 8,000 feet on the southwest flank to about 7,000 feet on the northeast flank of the Chuska Mountains. The water table in the Chuska Sandstone was assumed to be midway between land surface and this sloping plane. The travel distance (equivalent to $M$ in eq. 6) used to compute the hydraulic conductance was the water-table altitude minus the altitude of the sloping plane. The vertical hydraulic conductivity was simulated as 0.005 foot per day.

\section{Simulated Hydraulic Properties}

In addition to the hydraulic properties required to define boundary conditions and aquifer geometry, aquifer anisotropy and horizontal and vertical hydraulic conductivity are required to numerically describe steady-state ground-water flow. The hydrostratigraphic units that were simulated by the ground-water-flow model usually correlated with a single, well-defined geologic unit (fig. 36; fig. 5), making assignment of hydraulic properties relatively simple. For most units a single, areally uniform value for horizontal and another for vertical hydraulic conductivity produced satisfactory simulation results. These values are shown in figure 40 . The transmissivity distribution of each unit was obtained by multiplying the unit's horizontal hydraulic conductivity by the thickness of the unit at each model cell. Thicknesses were computed by using the GIS to manipulate the information given earlier regarding thickness and structural altitude of the tops of the hydrostratigraphic units.

The aquifer system was assumed to be anisotropic with the preferred direction of flow being northwest to southeast. The initial assumption was that all units are anisotropic. Final simulations portrayed only the transgressive, regressive units (post-Dakota Sandstone) as anisotropic. The basis for this, discussed earlier, was that the depositional environment of a series of shoreline transgressions and regressions would deposit sands that have a higher permeability in a direction parallel to the shoreline. However, the anisotropy probably is megascopic in origin and scale rather than due to grain orientation. That is, a series of intermeshed bars of sand combine to form a continuous aquifer. The longest unobstructed flow path within each bar is parallel to the shoreline; hence, on a large scale, the preferred direction of flow is in that direction. 


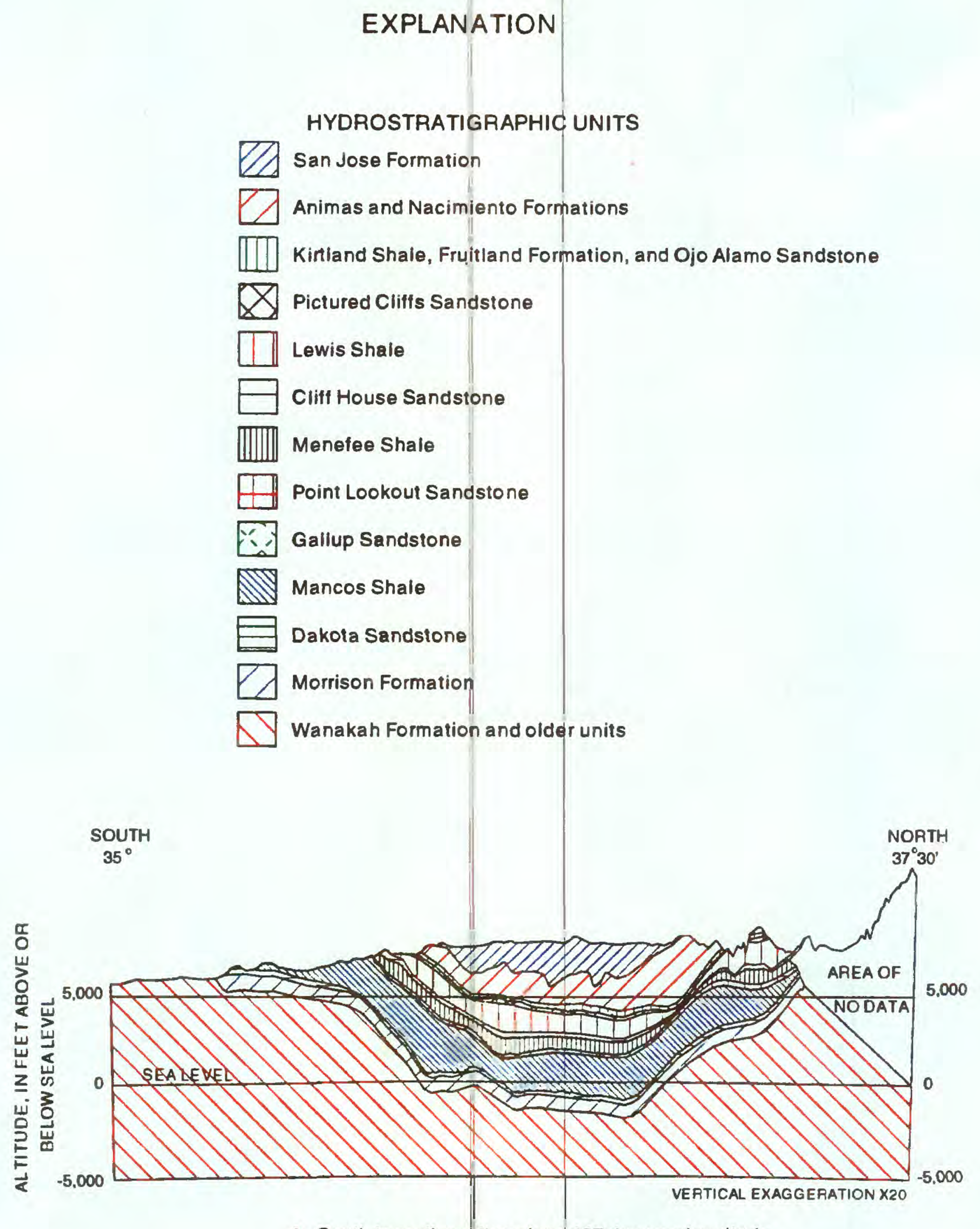

A. South to north section along 107 degrees longitude.

Figure 38.--South to north sections showing the vertical layers used in the model. 


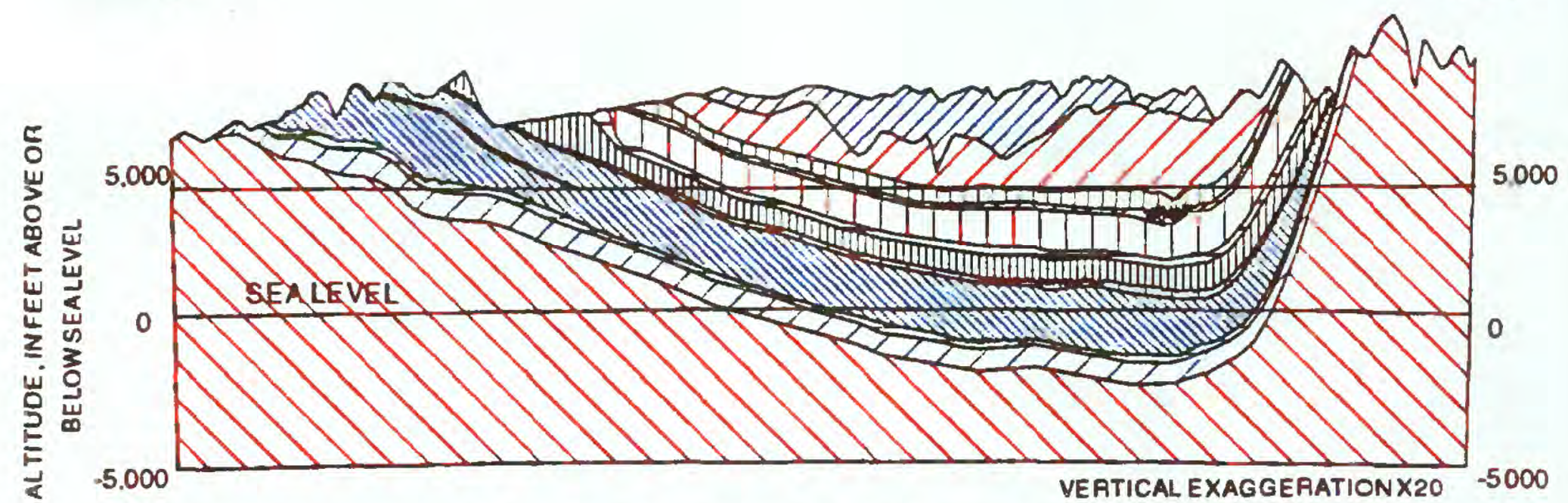

B. South to north section along 107 degrees 15 minules longitude.
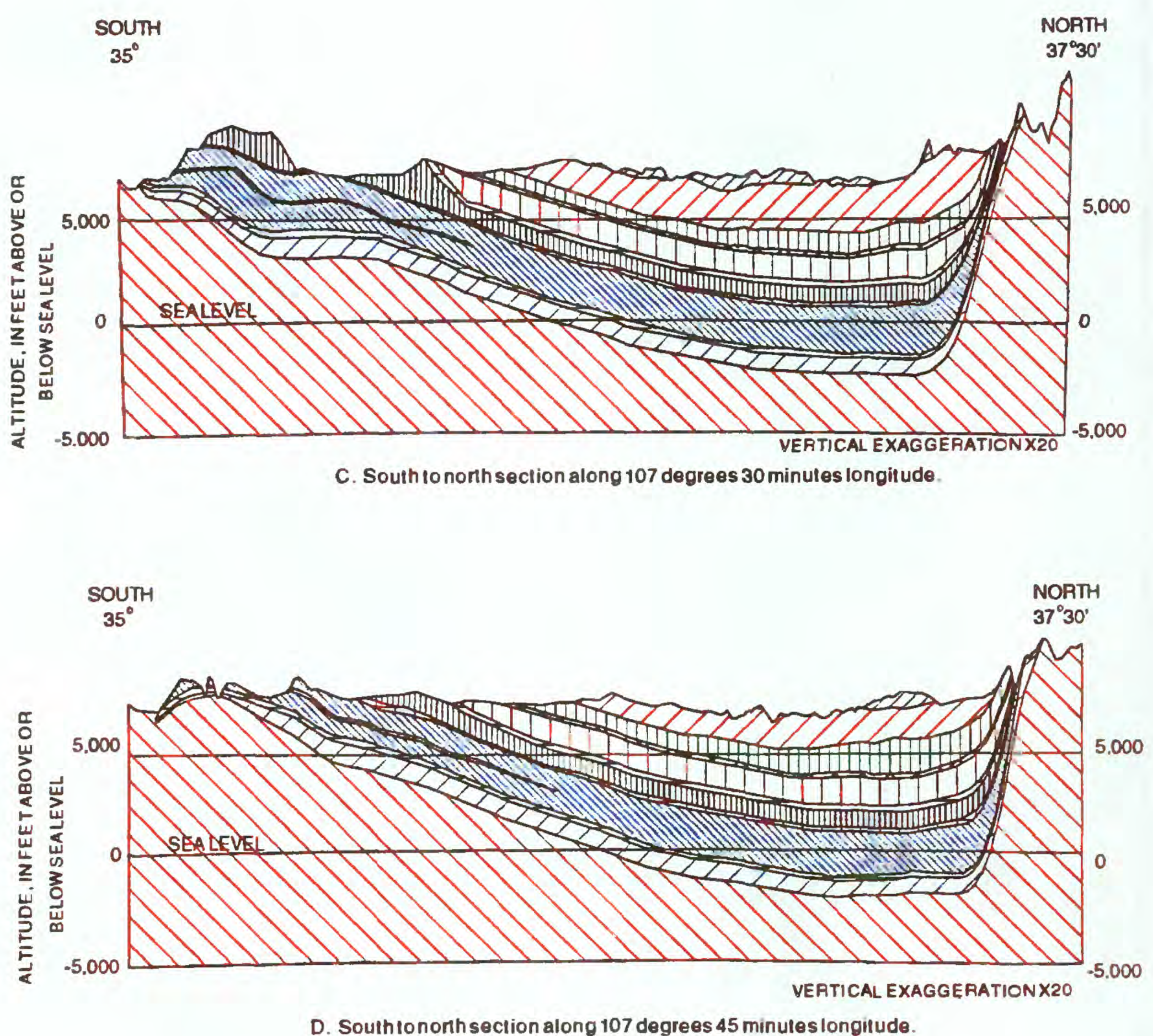

Figure 38.--South to north sections showing the vertical layers used in the model--Continued. 

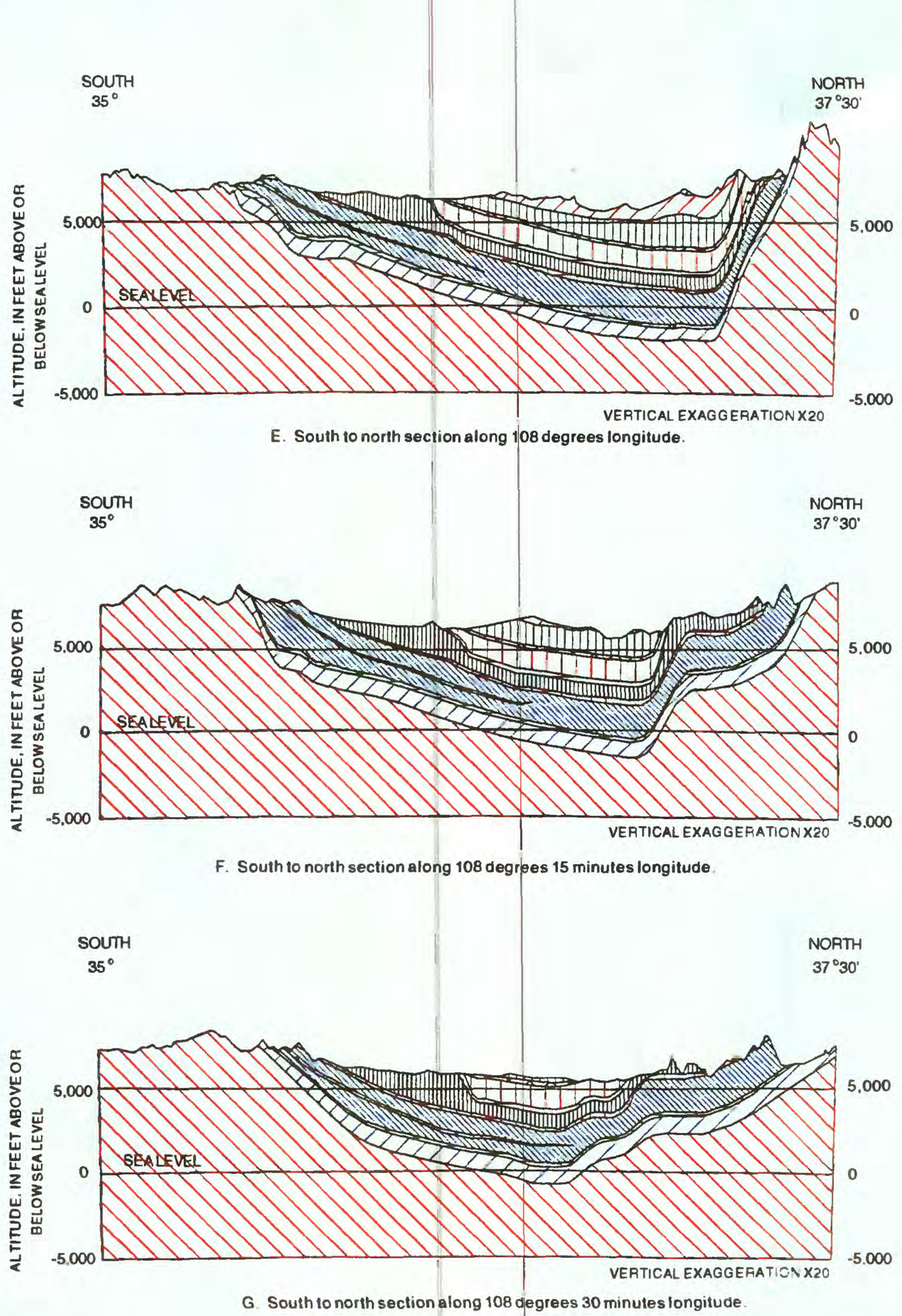

Figure 38.--South to north sections showing the vertical layers used in the model--Concluded. 


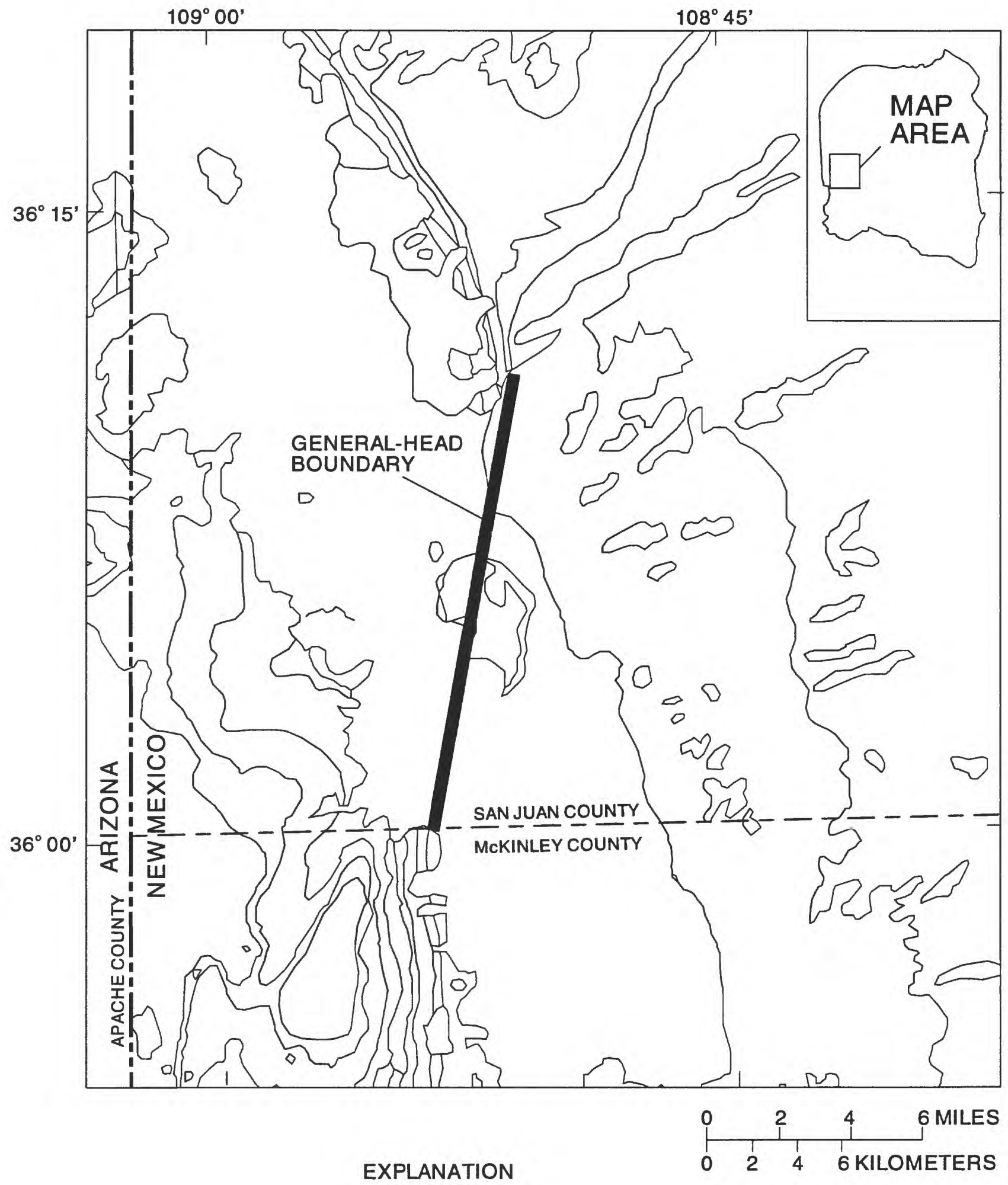

$\varpi$ GEOLOGIC CONTACT

Figure 39.--Location of the general-head boundary used to simulate the downward movement of water from the Chuska Sandstone, Deza Formation, and landslide deposits into the regional aquifers. 


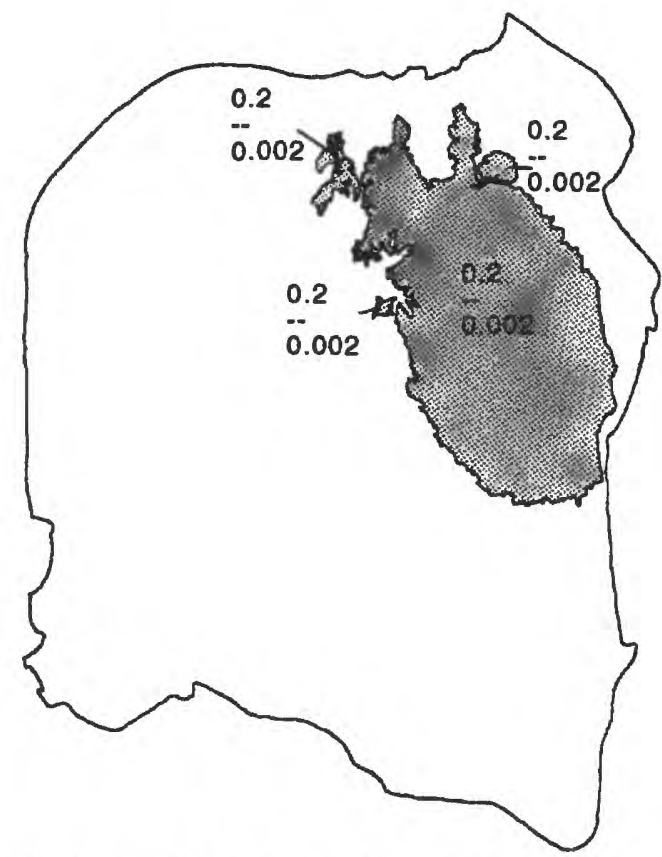

A. Simulated horizontal and vertical hydraulic conductivities for the San Jose Formation.

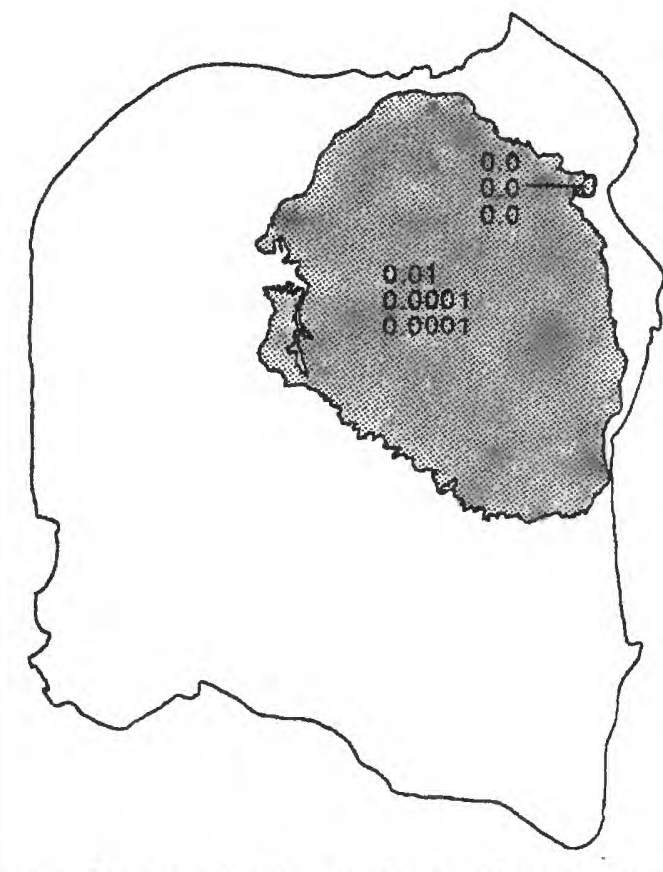

B. Simulated horizontal and vertical hydraulic conductivities for the Animas and Nacimiento Formations.

$\begin{array}{llllllll}0 & 10 & 20 & 30 & 40 & 50 & 60 & \text { MILES }\end{array}$

102030405060 KILOMETERS

\section{EXPLANATION}

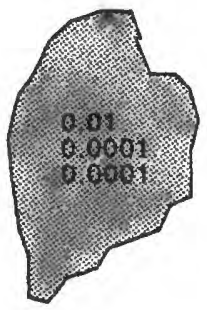

AREA OF HYDRAULIC-CONDUCTIVITY DATA-.

Upper number is horizontal, middle number is upper vertical, and lower number is lower vertical hydraulic conductivity, in feet per day. Dashes indicate value not used.

Figure 40.--Simulated horizontal and vertical hydraulic conductivities. 


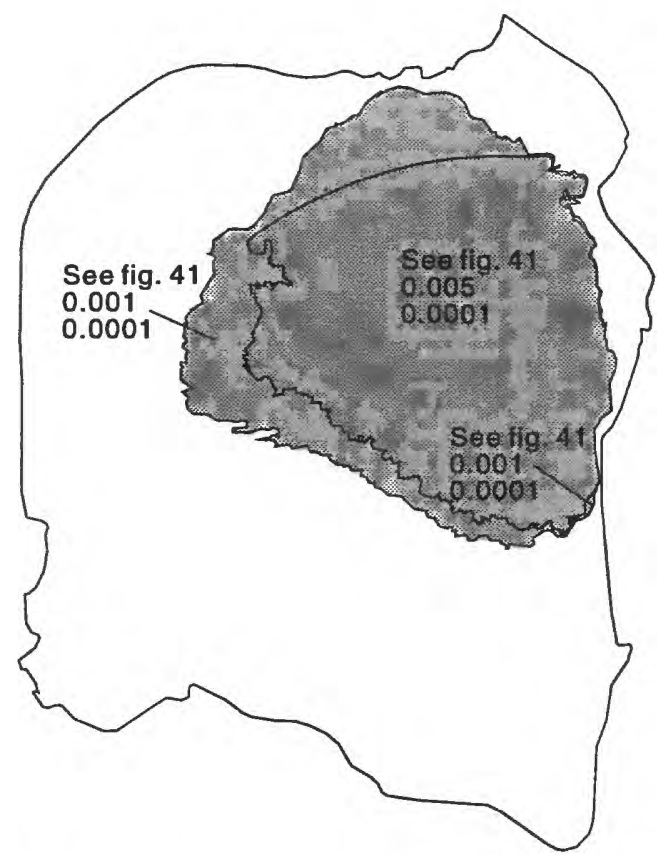

C. Simulated vertical hydraulic conductivities for the combined Ojo Alamo Sandstone, Kirtland Shale, and Fruitland Formation.

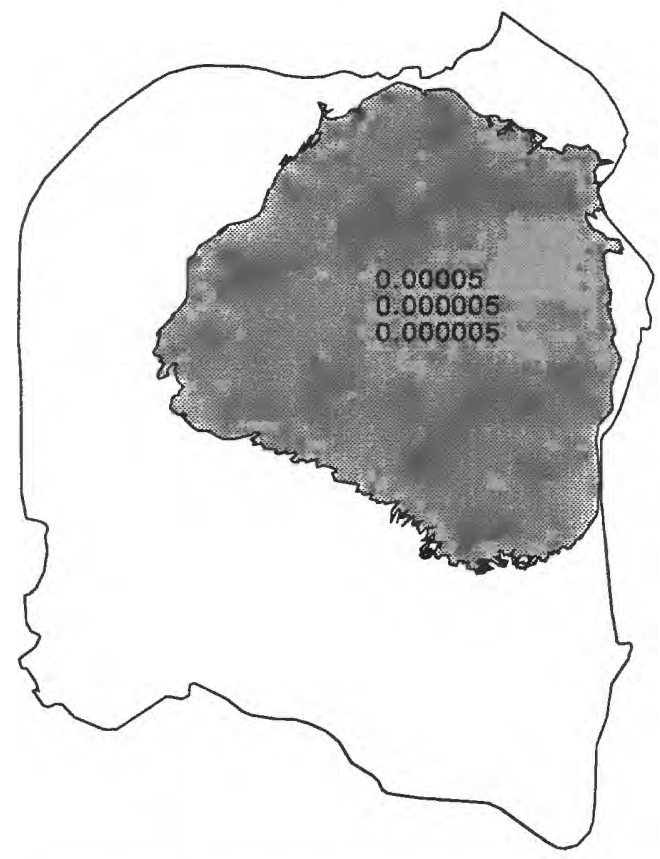

E. Simulated horizontal and vertical hydraulic conductivities for the Lewis Shale.

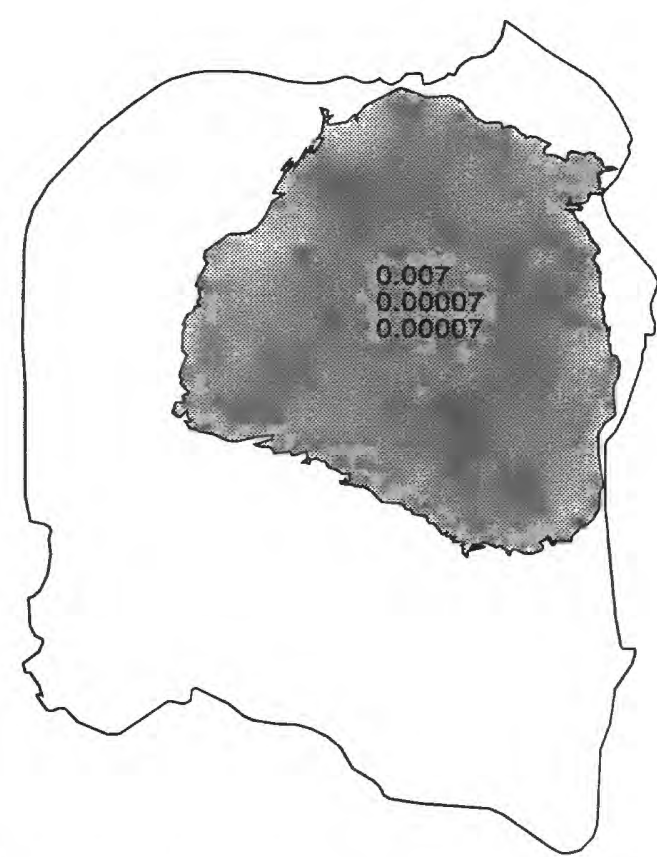

D. Simulated horizontal and vertical hydraulic conductivities for the Pictured Cliffs Sandstone.

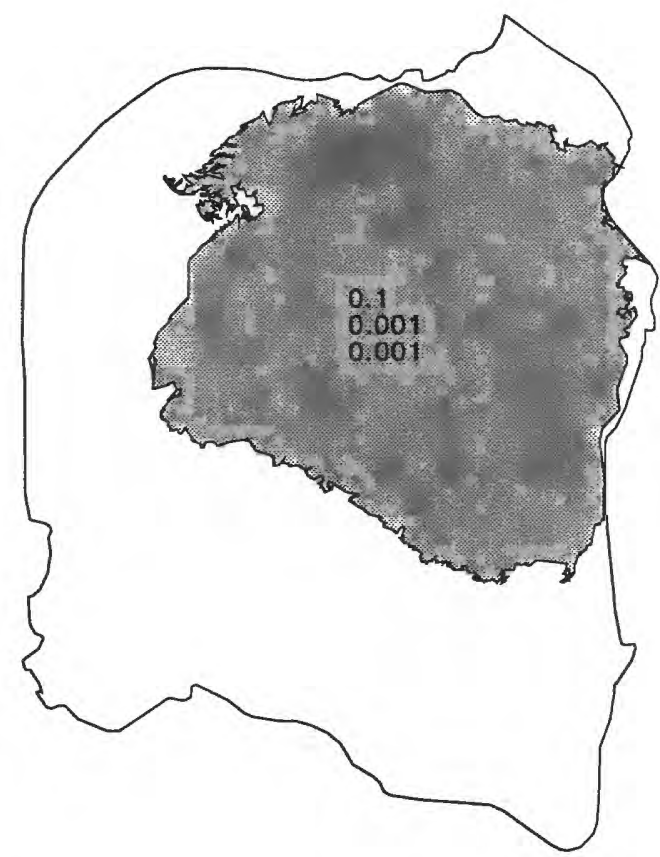

F. Simulated horizontal and vertical hydraulic conductivities for the Cliff House Sandstone.

Figure 40.--Simulated horizontal and vertical hydraulic conductivities--Continued. 

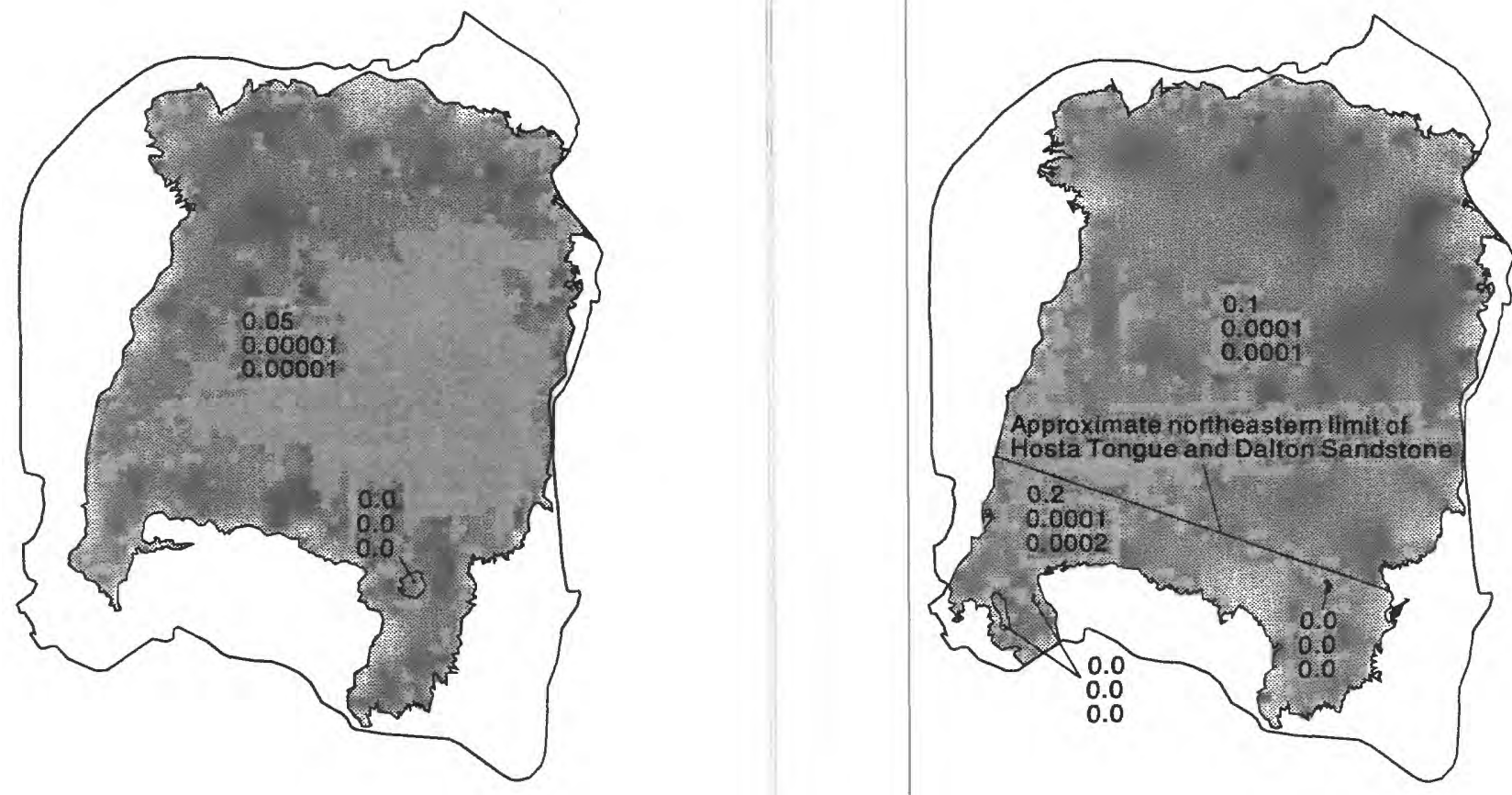

G. Simulated horizontal and vertical hydraulic conductivities for the Menefee Shale.

H. Simulated horizorital and vertical hydraulic conductivities for the Point Lookout Sandstone.
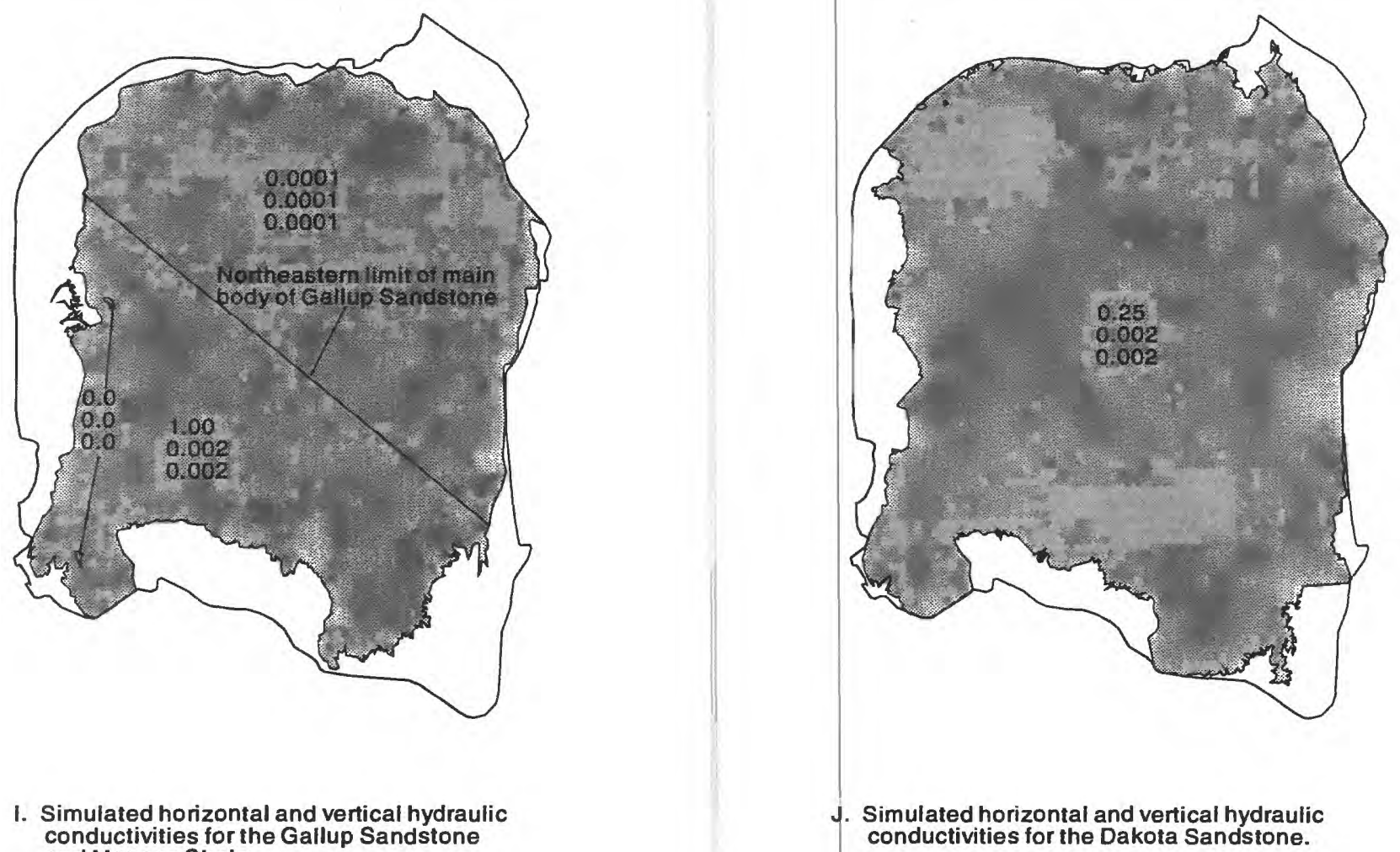

Simulated horizontal and vertical hydraulic and Mancos Shale. 


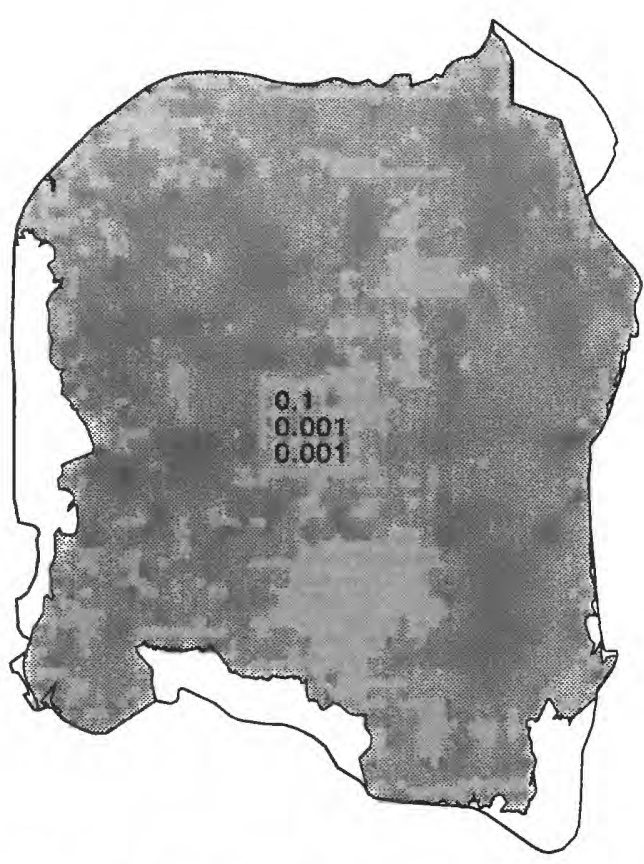

K. Simulated horizontal and vertical hydraulic conductivities for the Morrison Formation.

Figure 40.--Simulated horizontal and vertical hydraulic conductivities--Concluded.

Most units could be described in simple hydrologic terms; however, the units represented by model layers 3,8 , and 9 were more complex, requiring zoned values of hydraulic conductivity and different values of upward and downward vertical hydraulic conductivity. The units represented by layer 3 are the Ojo Alamo Sandstone, Kirtland Shale, and Fruitland Formation. This combination of units in one layer was formed because information was insufficient to separate the Kirtland and Fruitland into individual hydrostratigraphic units, the Ojo Alamo was thin enough to present serious problems defining tops and bottoms that did not conflict with adjacent units, and the Ojo Alamo pinched out in the subsurface. The solution was to combine the units. The upward vertical hydraulic conductivity is greater than the downward (fig. 40C) to reflect the higher permeability of the Farmington Sandstone Member of the Kirtland Shale and of the Ojo Alamo Sandstone. The horizontal hydraulic conductivity (fig. 41) was computed as the thickness-weighted mean of the conductivities of the Ojo Alamo and Kirtland-Fruitland subunits. In this computation the values of hydraulic conductivity of the Ojo Alamo and Kirtland-Fruitland subunits were assumed to be 1 and 0.01 foot per day, respectively.

The units represented by layer 8 are the main body and Hosta Tongue of the Point Lookout Sandstone and the Crevasse Canyon Formation (primarily the Dalton Sandstone Member). The main body of the Point Lookout Sandstone is persistent and fairly uniform throughout the basin, but the Hosta Tongue and Dalton Sandstone occur only in the south and southwestern part of the basin. At the southern margin of the basin the three units are stacked upon each other with only minor separation by thin tongues of the Mancos Shale and Cleary Coal Member of the Crevasse Canyon. The diagonal line separating conductivity zones in figure $40 \mathrm{H}$ is the approximate northeastern limit of the Hosta Tongue and Dalton Sandstone.

The units represented by layer 9 are the main body of the Gallup Sandstone and a thin, arbitrary interval in the middle of the Mancos Shale. The diagonal line in figure 40I (also see fig. 33) represents the northeastern limit of the main body of the Gallup Sandstone. Northeast of this line model layer 9 represents a thin interval of the Mancos Shale with appropriately low horizontal and vertical hydraulic conductivities. 


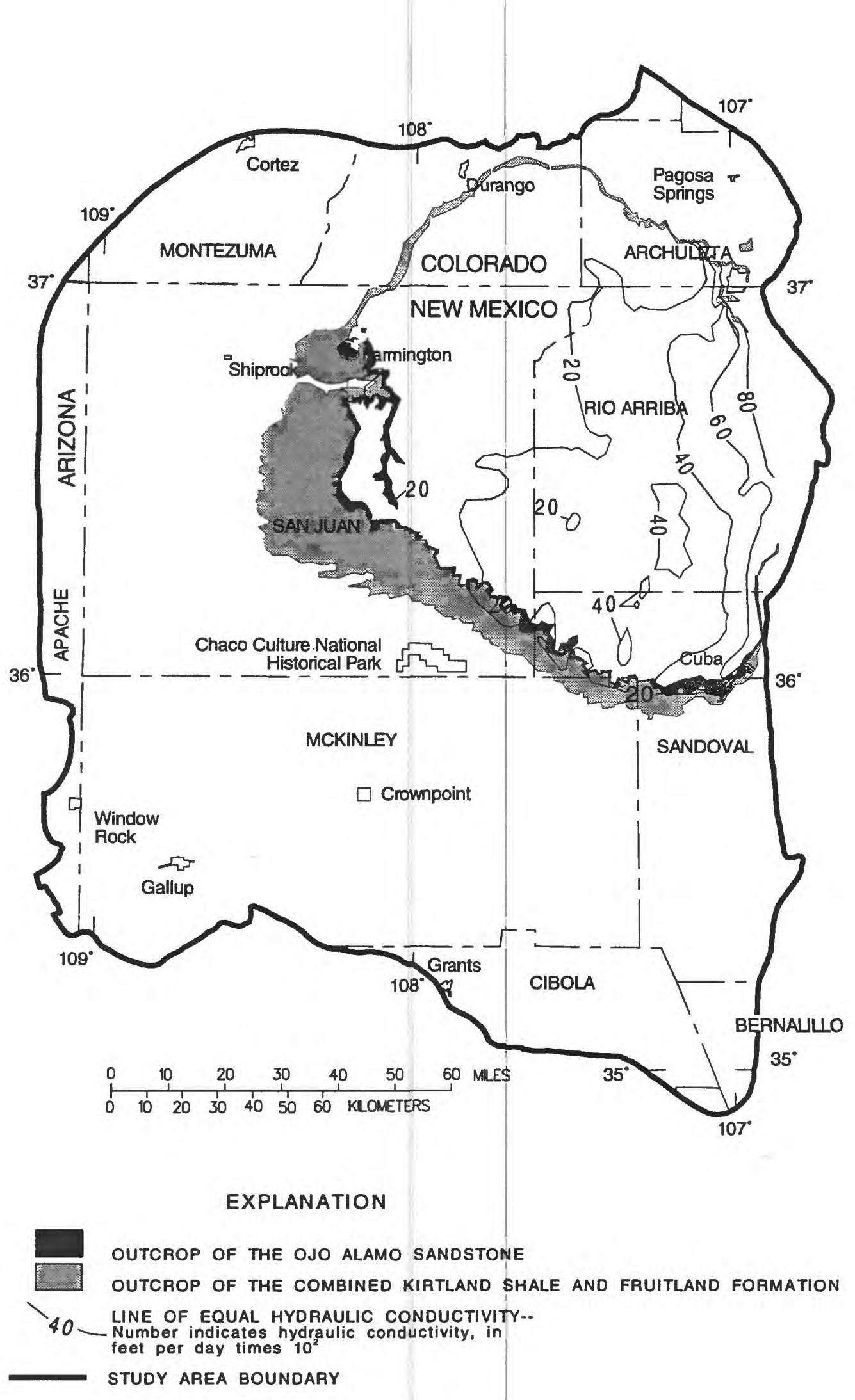

Figure 41.--Simulated horizontal hydraulic conductivity for the combined Ojo Alamo Sandstone, Kirtland Shale, and Fruitland Formation. 
The top and bottom of the Entrada Sandstone were not determined because of insufficient control data. Therefore the unit was simulated as being uniformly transmissive (fig. 42). Because the Entrada Sandstone is the basal unit in the simulation there is no downward vertical hydraulic conductivity.

The degree of vertical hydraulic connection between hydrostratigraphic units is a function of the vertical hydraulic conductivity and the thicknesses of the units. Because the conductances (hydraulic conductivity divided by thickness) are in series, the net vertical leakance between units is the harmonic mean of the conductances of the two adjacent units. The model (McDonald and Harbaugh, 1988, chap. 5, p. 11-12) multiplies cell area by vertical leakance to obtain vertical conductance. The equation to determine the vertical leakance between two units (units $a$ and $b$ ) is:

$$
V C O N T=\frac{1}{\frac{M_{a} / 2}{V K_{a}}+\frac{M_{b} / 2}{V K_{b}}}
$$

where $V C O N T$ is the vertical leakance $(1 / t)$;

$M_{a}, M_{b}$ are the thicknesses of units $a$ and $b(\mathrm{~L})$; and

$V K_{a}, V K_{b}$ are the vertical hydraulic conductivities of units $a$ and $b(\mathrm{~L} / \mathrm{t})$.

By examination of equation 7 one can determine that a low-conductivity unit will have the dominant term in the denominator. In instances where a low hydraulic-conductivity unit is not explicitly simulated (indicated by VK in fig. 36 ), a third term in the denominator, $\left(M_{\mathrm{c}} / V K_{\mathrm{c}}\right)$, usually is vastly dominant over the other two.

\section{MODEL CALIBRATION AND SENSITIVITY ANALYSIS}

The steady-state ground-water-flow model of the San Juan Basin did not undergo the typical lengthy process of calibration; the boundary conditions, including internal geometry, were defined and representative values for hydraulic properties were selected on the basis of known aquifer tests and previous reports. The initial model configuration produced generally acceptable results but some refinements, discussed below, were necessary.

The most likely reason that the model needed very little refinement to achieve acceptable calibration is that the dominant controls on the steady-state ground-water-flow system in the San Juan Basin are the boundary conditions, variations in hydraulic properties resulting from different depositional environments, and internal geometry of the aquifer-system components, all described earlier. Because a GIS was used to describe these aquifer-system properties and construct input data for the model, minute details could be portrayed with great accuracy. The accurate portrayal of the boundaries led, in turn, to a quickly calibrated model of the flow system. 


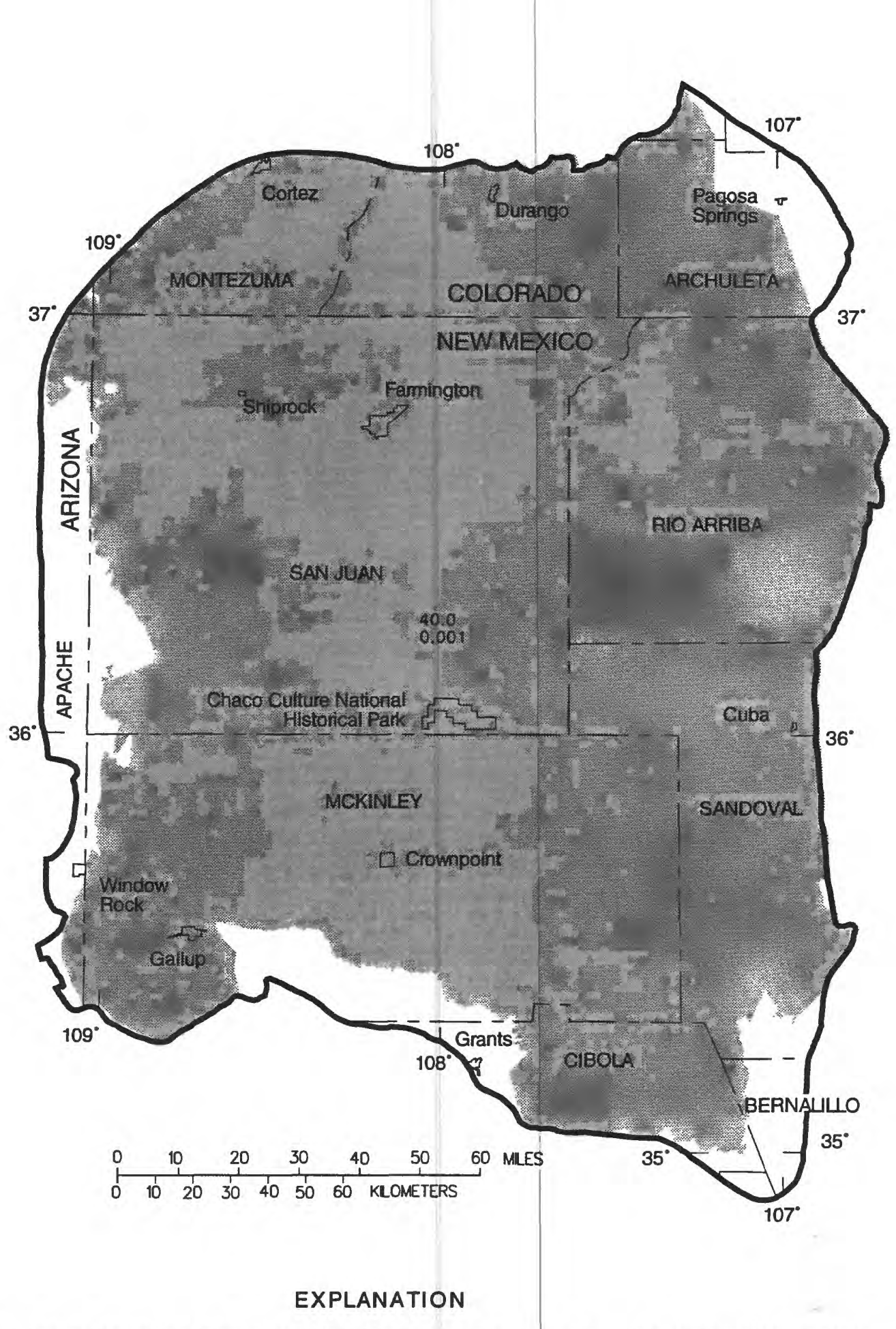

AREA OF SIMULATED TRANSMISSIVITY AND UPWARD VERTICAL HYDRAULIC CONDUCTIVITY-Upper number is transmissivity, in feet squared per day. Lower number is upward hydraulic conductivity, in feet per day

STUDY AREA BOUNDARY

Figure 42.--Simulated horizontal transmissivity and upward vertical hydraulic conductivity for the Entrada Sandstone. 
Calibration of the steady-state ground-water-flow model of the San Juan Basin consisted of matching as closely as possible computed and measured potentiometric heads for a few key wells in the central part of the basin. The selected wells each were completed in a single hydrostratigraphic unit and had measured potentiometric heads that approximated predevelopment conditions. Calibration of the model around the perimeter of the basin was unnecessary because water-level altitudes are closely controlled by recharge and surface-water boundaries. Because the altitudes of the surface-water boundaries were obtained from digital elevation models having a vertical accuracy of 30 meters, computed water-level altitudes in and near the outcrops were not expected to exceed this accuracy. Because the vertical error in landsurface altitude supposedly is not systematic, however, the actual error between computed and measured potentiometric heads in the central part of the basin was expected to be less than 100 feet. For the final steady-state model the average error for control wells completed in the Cliff House and Point Lookout Sandstones and the Morrison Formation was about 50 feet.

\section{Preconditioned Hydraulic-Head Distribution}

The hydraulic head used to begin the steady-state simulations was set equal to the altitude at land surface for all model layers. During the first steady-state simulation computed potentiometric heads decayed in the outcrop areas to the level of equilibrium determined by local recharge and surface-water boundaries. In the central part of the basin the potentiometric heads decayed to a level that reflected the hydraulic properties of the aquifers and a distance-weighted average of the potentiometric heads in the outcrop areas. Once a steady-state solution was obtained the heads from that solution were used as initial heads for other simulations, with the exception that landsurface altitude again was used as initial heads for the top model layer.

\section{Model Refinements and Sensitivity to Changes in Simulated Aquifer Properties}

Although some improvements and refinements were made to the model, most changes led to undesired or no significant change. The most positive change was the inclusion of a general-head boundary to represent the hydrologic effects of the Chuska Mountains on underlying aquifers in the regional system; the initial simulation excluded this source of recharge to the regional system. Another change that greatly improved the simulation was reducing the rate of direct recharge to the Lewis Shale and Menefee Formation to one-tenth the rate for the other units, and limiting recharge to only the Ojo Alamo Sandstone subunit of the combined Ojo Alamo Sandstone, Kirtland Shale, and Fruitland Formation hydrostratigraphic unit. This last change represented the high rate of runoff from the near-barren shales and was necessary to prevent the low hydraulic conductivity of these shale units from causing excessive mounding of water in their outcrop areas.

The model was much less sensitive to either of the two previous changes than to changes in hydraulic conductivity and anisotropy. Doubling or halving these properties in the simulations resulted in approximately a 50-foot change in computed hydraulic head in the center of the basin. Changes generally were less elsewhere, especially in the near-outcrop areas.

The model was even less sensitive to changes in simulated vertical conductance (vertical leakance). This probably is due to the relatively low vertical gradients that exist across great thicknesses of units having low hydraulic conductivity. The low vertical gradients support the observation that the primary controls on steady-state potentiometric heads are in the outcrop areas of the aquifers. 
The change having the least effect was the simulation of the interaction of the Dakota Sandstone with the San Juan River across the Mancos Shale. A general-head boundary was used to test the effect of simulating leakage from the Dakota Sandstone upward across the Mancos Shale and discharging to the surface-water system of the San Juan River and valley alluvium. No change was noted in computed heads in the Dakota Sandstone. The quantity of water leaking upward across the Mancos Shale is insufficient to affect potentiometric heads in the underlying Dakota Sandstone.

\section{DISCUSSION OF SIMULATION ANALYSES}

The most clearly defined conclusion resulting from the simulations was that steady-state hydraulic heads in the San Juan Basin are firmly controlled by boundary conditions and the internal geometry of the hydrostratigraphic units. The primary boundary types that exert the most control are stream-aquifer interaction, recharge from direct precipitation, and recharge to some units of the regional system by leakage through the Chuska Sandstone.

Wide-ranging variations in the values of simulated hydraulic properties resulted in modest changes in computed hydraulic head, especially near the aquifer outcrop areas. The greatest variations in computed head were in the central part of the basin, away from the outcrop boundaries. Finally, the general pattern of head distribution never really changed throughout the analysis of the effects of changes in simulated hydraulic properties. The computed heads for the major water-yielding hydrostratigraphic units are shown in figures 43-53. A hydraulic-head map is not shown for the Lewis Shale because it could not be expected to yield water to a well, nor are heads plotted for the areas of outcrop (except for the San Jose and Menefee Formations), where local topography often dominates ground-water levels.

Although the computed steady-state hydraulic heads compare reasonably well with early measured heads in the major aquifers (Gallup, Dakota, and Morrison) in the central part of the basin, data are insufficient for comparison in the younger units except in the aquifer outcrop areas where water levels are strongly controlled by topographic altitude. Away from the outcrop areas most hydraulic-head measurements in the basin reflect post-development conditions.

Vertical hydraulic-head gradients under steady-state conditions near the center of the basin often were unexpectedly low despite low values of vertical hydraulic conductivity and thick intervening intervals of confining units between the primary aquifers. This is largely attributable to the dominance of outcrop boundary conditions on the potentiometric-head distribution and the similarity of boundary conditions for stratigraphically adjacent units. The vertical flow directions between selected adjacent hydrostratigraphic units are shown in figure 54 .

The Dakota Sandstone, Morrison Formation, and Entrada Sandstone exhibit similar hydraulic heads. From the Dakota Sandstone upward the differences in computed hydraulic head between units are greater because of the presence of thick shale sequences. The distinct differences in hydraulic head between the Gallup and Dakota Sandstones and the Point Lookout and Gallup Sandstones are due to the very large isolating thicknesses of the upper and lower Mancos Shale and the thinning and pinch-out of the Gallup Sandstone in the subsurface. Likewise, there are significant head differences across the Ojo Alamo Sandstone, Kirtland Shale and Fruitland Formation, and the Lewis Shale and Menefee Formation. 


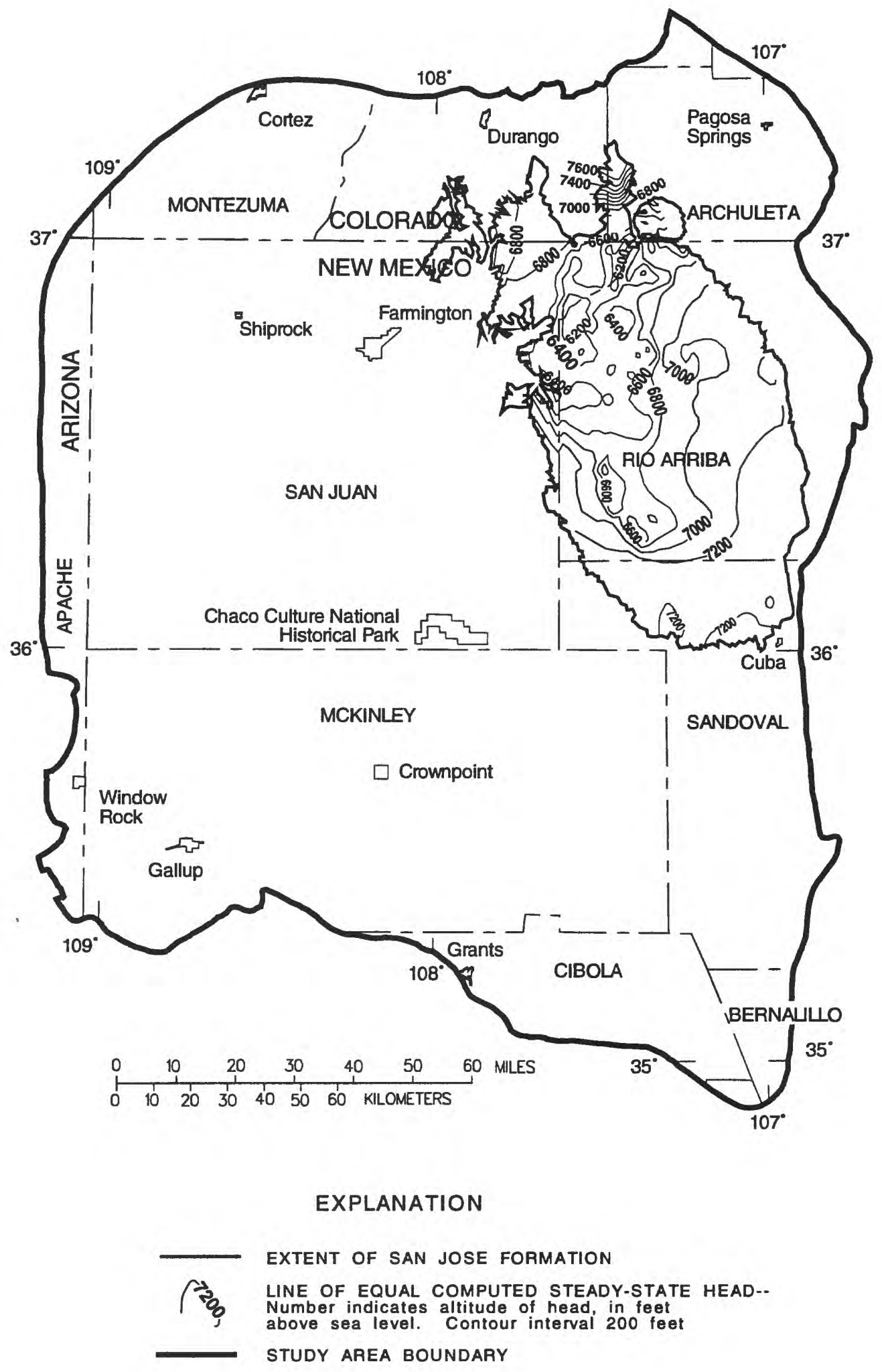

Figure 43.--Computed steady-state head in the San Jose Formation. 


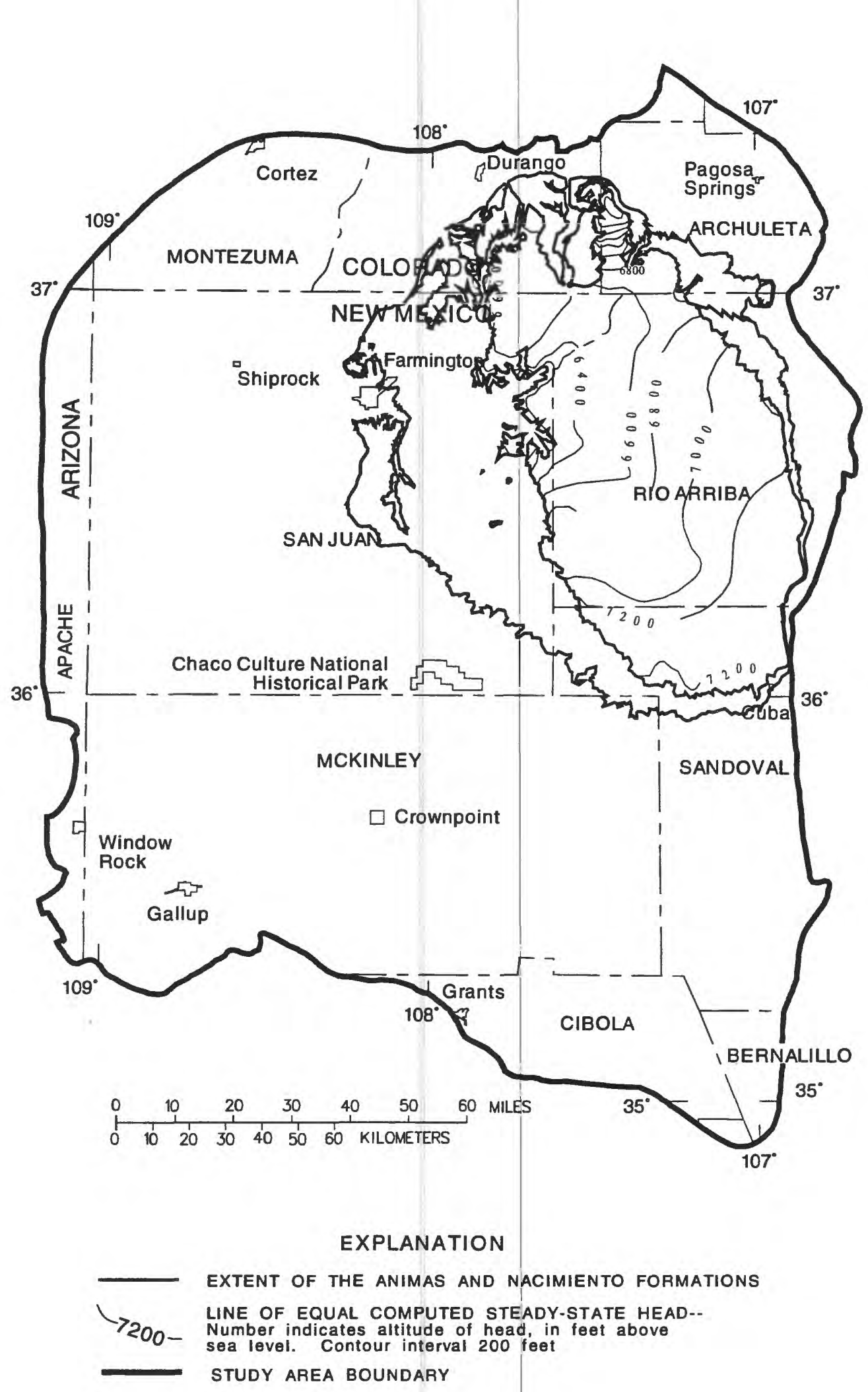

Figure 44.--Computed steady-state head in the Animas and Nacimiento Formations. 


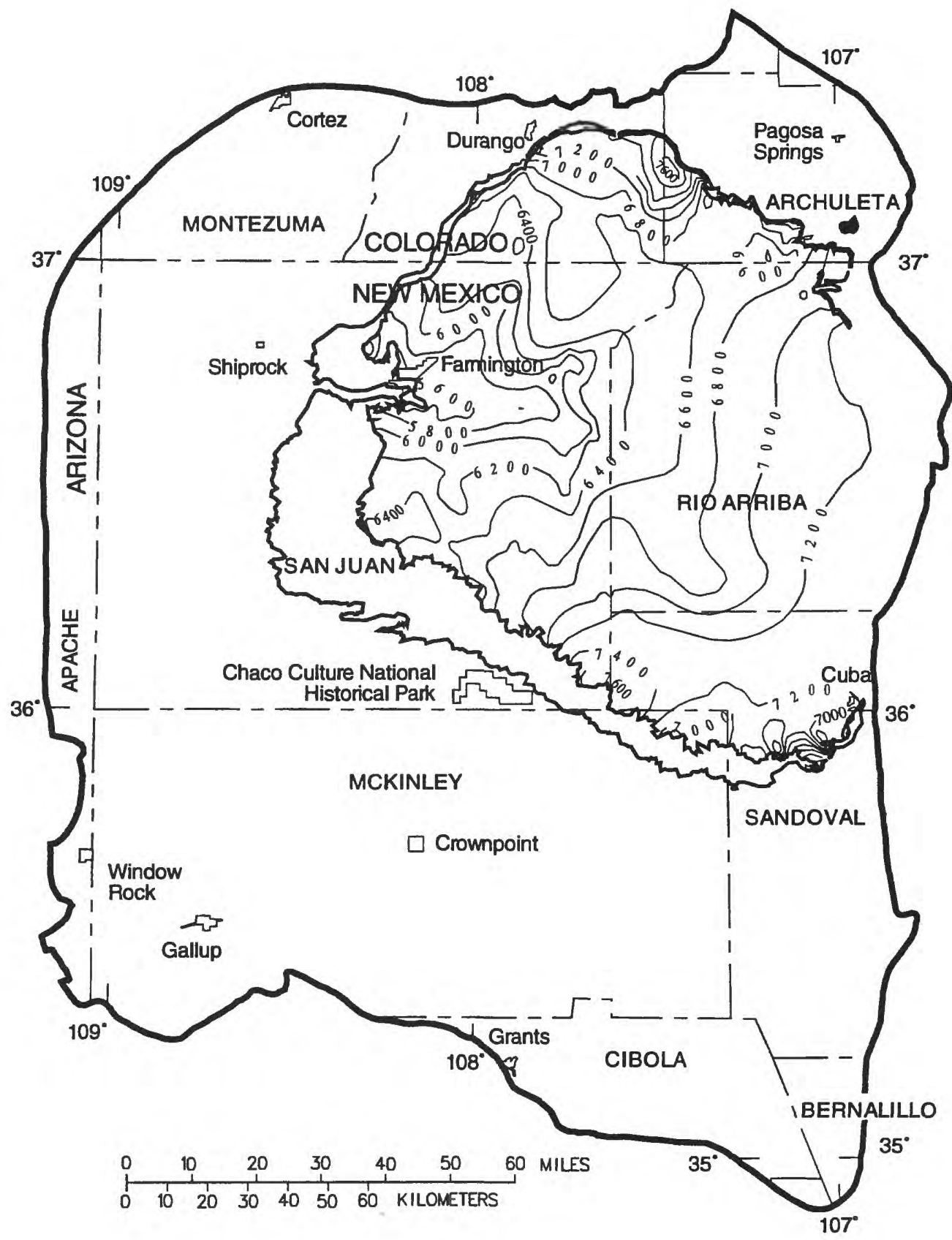

\section{EXPLANATION}

EXTENT OF THE COMBINED OJO ALAMO SANDSTONE, KIRTLAND SHALE, AND FRUITLAND FORMATION

$\rightarrow 0_{0} 0^{-}$LINE OF EQUAL COMPUTED STEADY-STATE HEADsea level. Contour interval 200 feet

$\longrightarrow$ STUDY AREA BOUNDARY

Figure 45.--Computed steady-state head in the combined Ojo Alamo Sandstone, Kirtland Shale, and Fruitland Formation. 


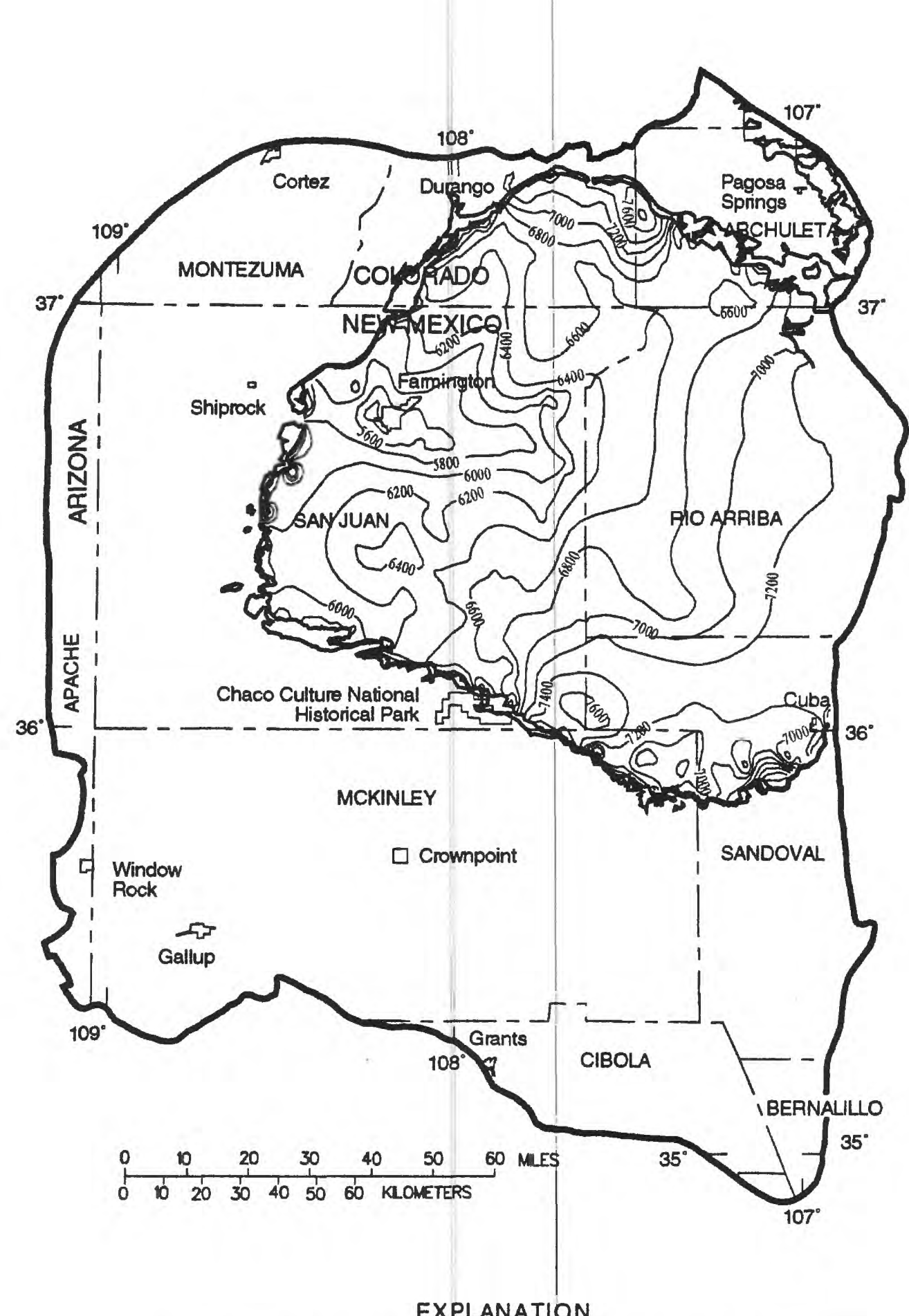

\section{EXPLANATION}

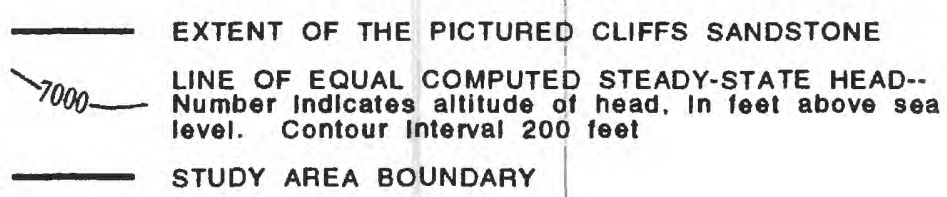

Figure 46.--Computed steady-state head in the Pictured Cliffs Sandstone. 


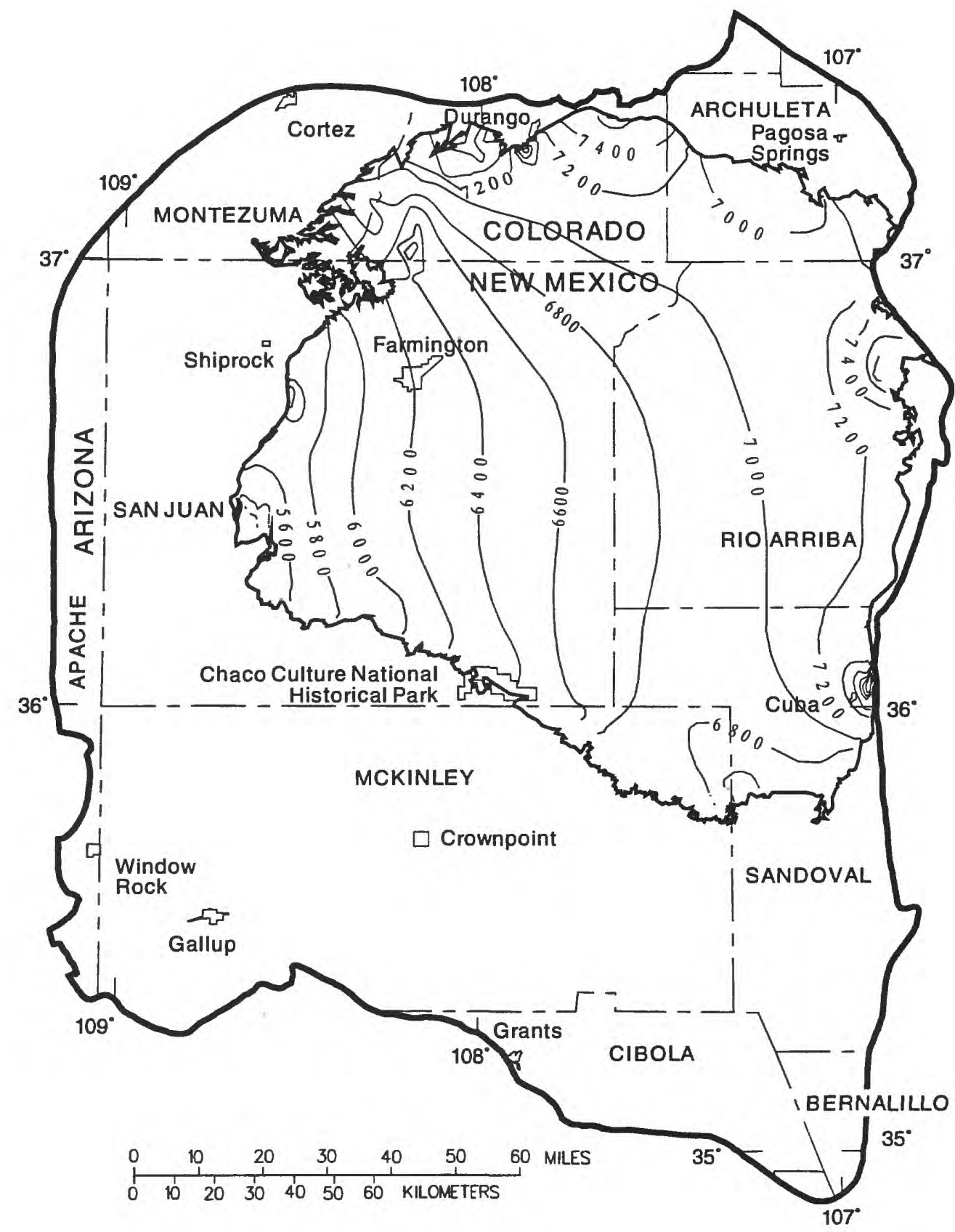

\section{EXPLANATION}

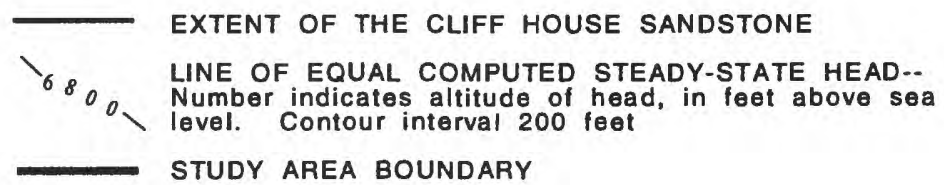

Figure 47.--Computed steady-state head in the Cliff House Sandstone. 


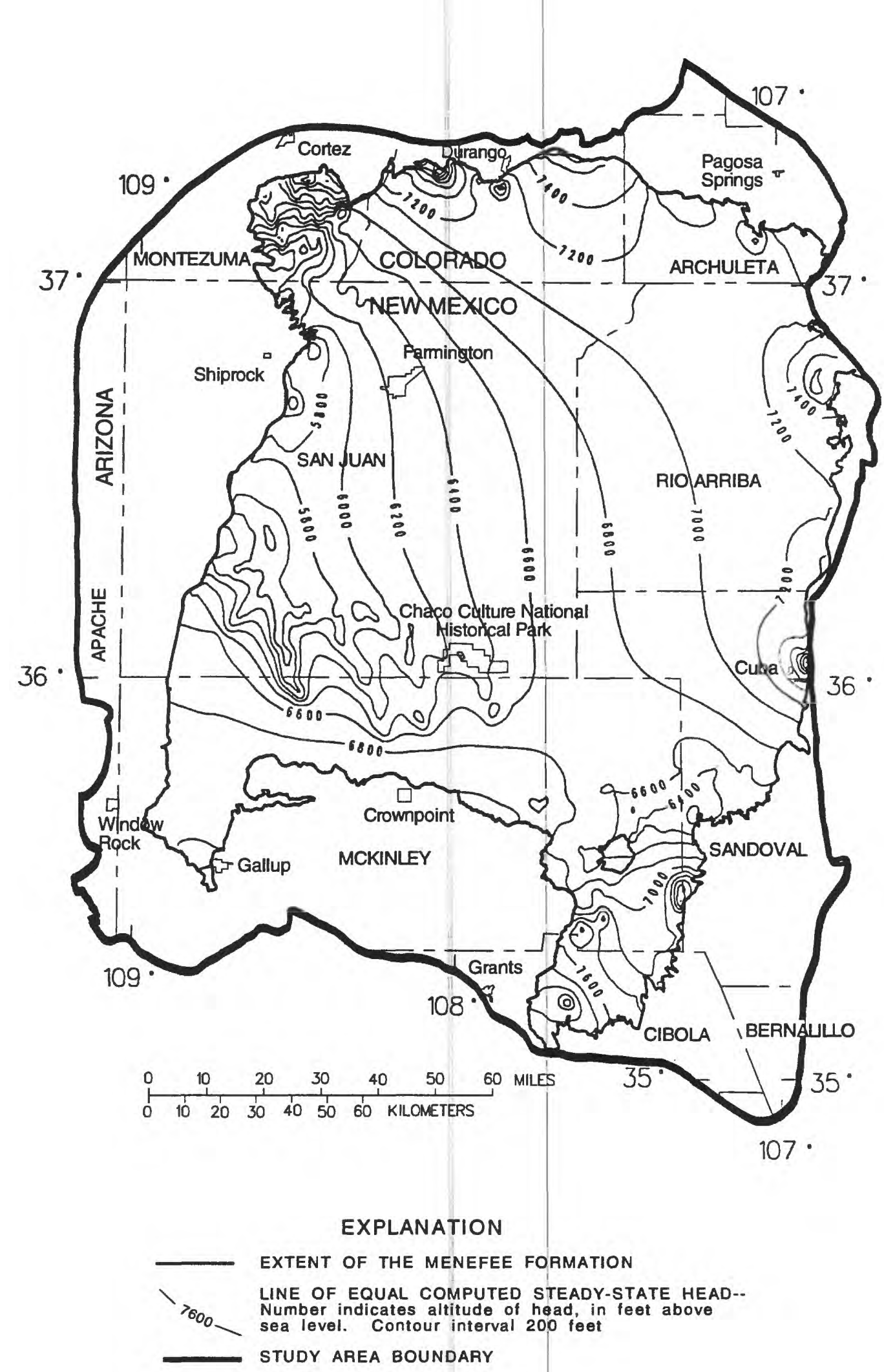

Figure 48.--Computed steady-state head in the Menefee Formation. 


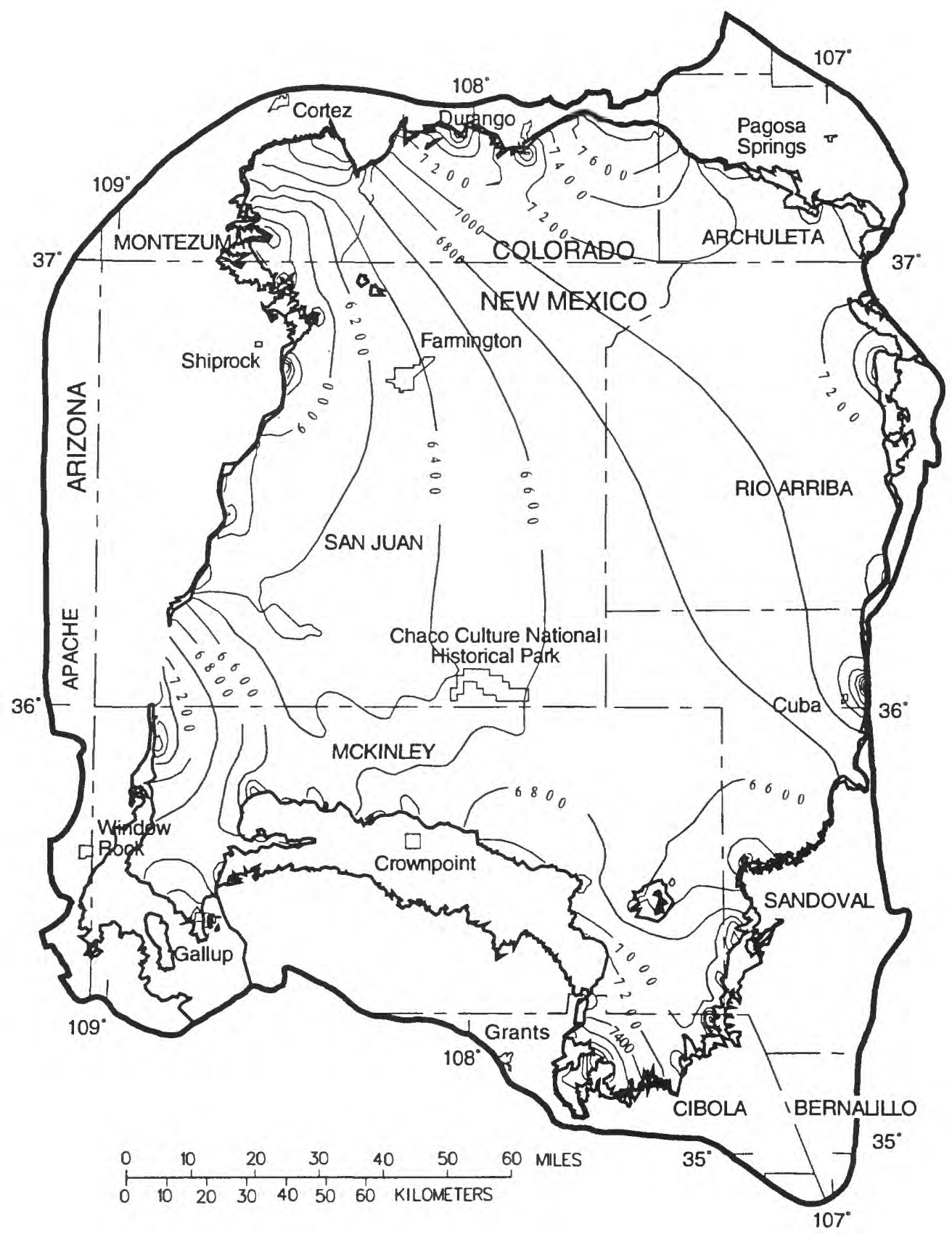

EXPLANATION

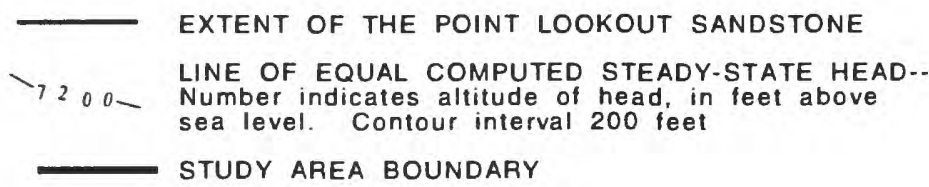

Figure 49.--Computed steady-state head in the Point Lookout Sandstone. 


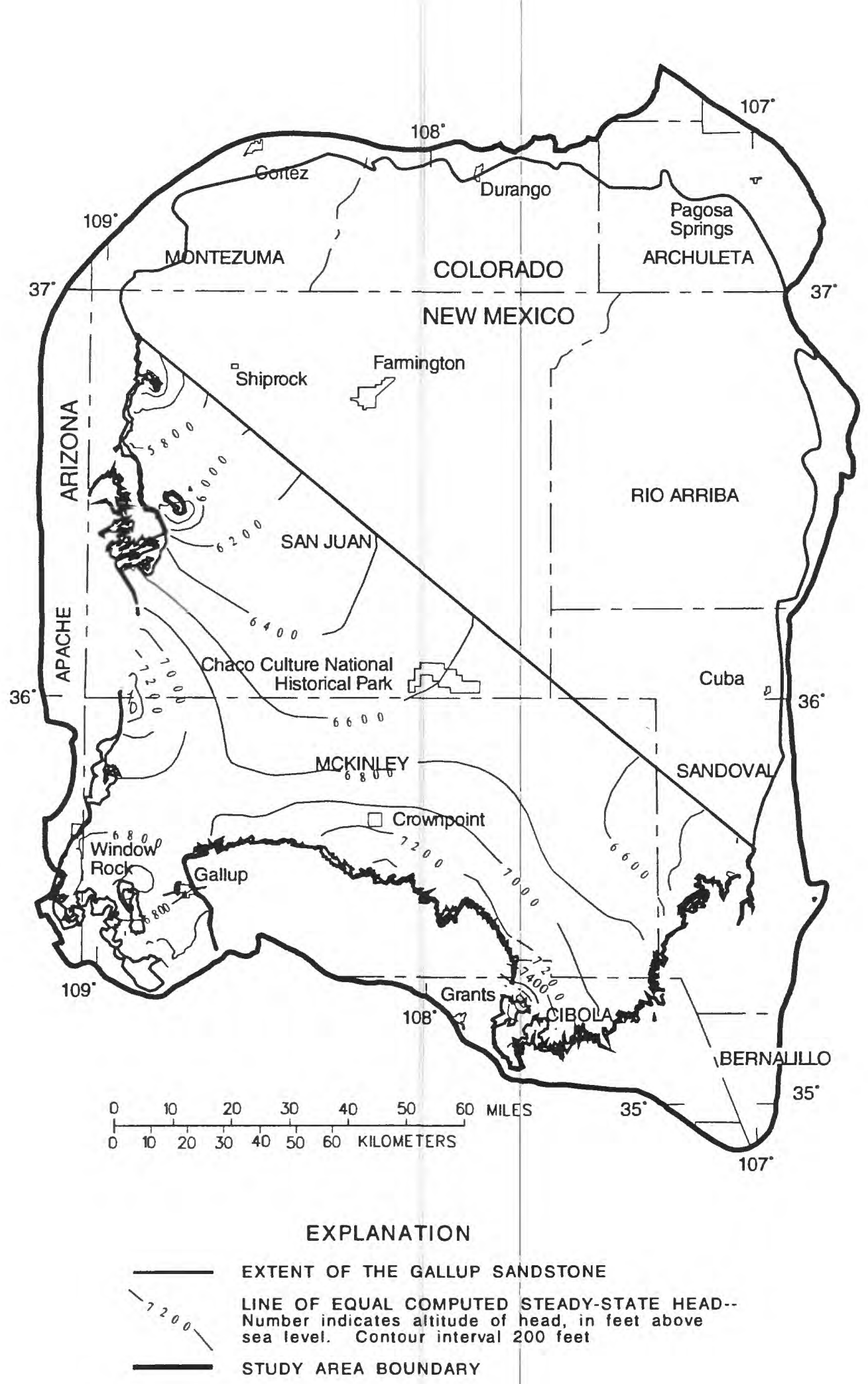

Figure 50.--Computed steady-state head in the Gallup Sandstone. 


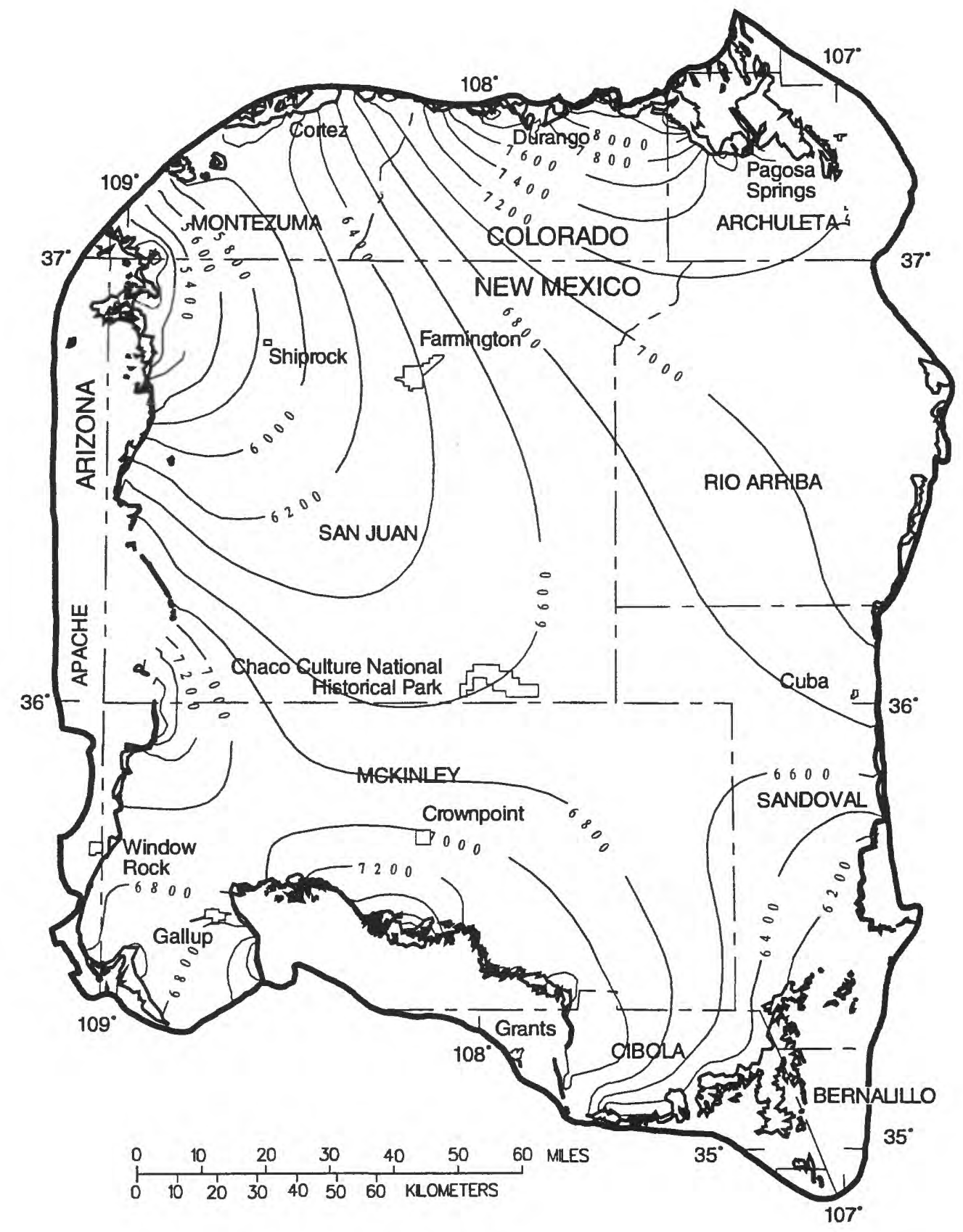

\section{EXPLANATION}

\section{EXTENT OF THE DAKOTA SANDSTONE}

-6800- LINE OF EQUAL COMPUTED STEADY-STATE HEAD--
Number indicates altitude of head, in feet above
sea level. Contour interval 200 feet

Figure 51.--Computed steady-state head in the Dakota Sandstone. 


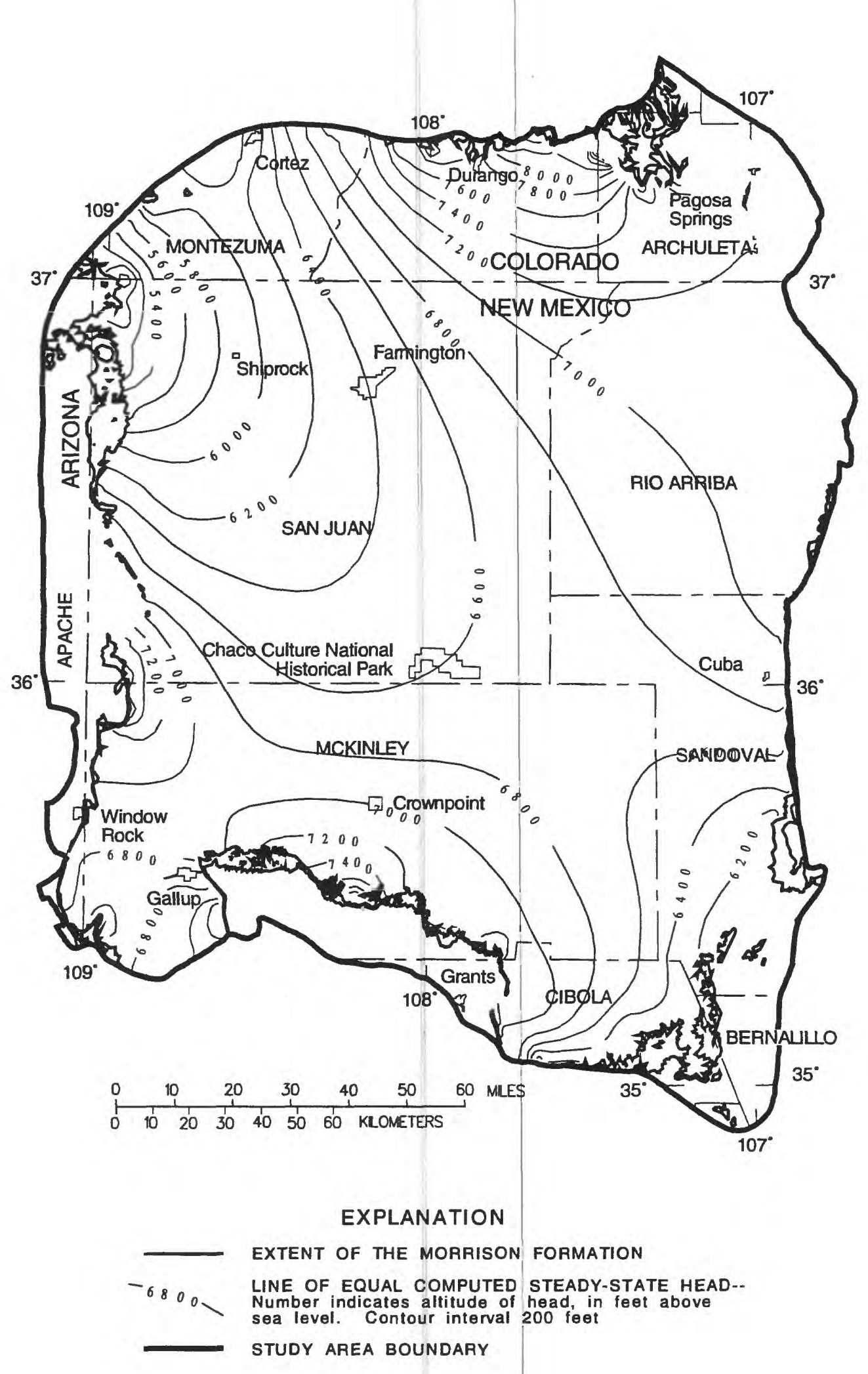

Figure 52.--Computed steady-state head in the Morrison Formation. 


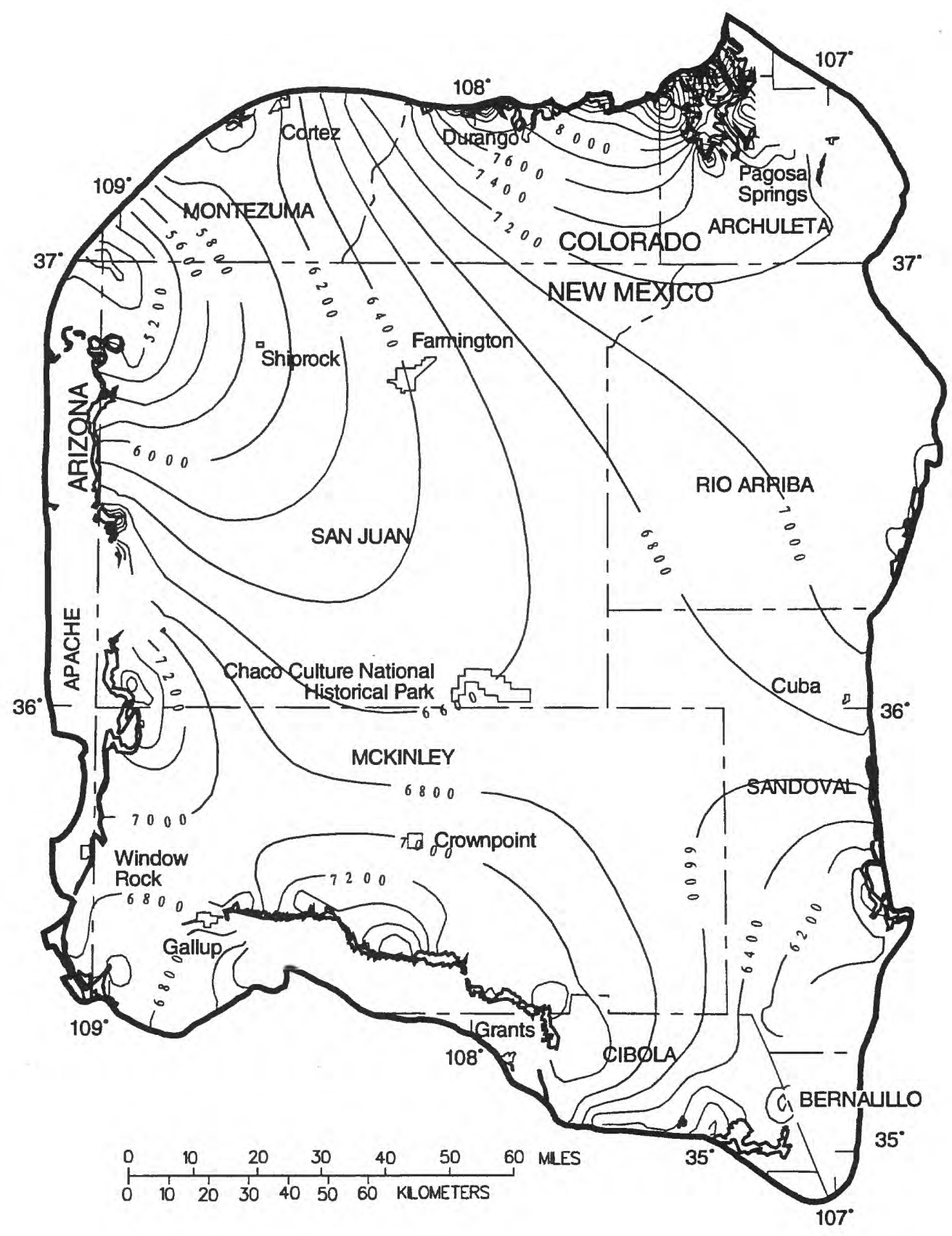

EXPLANATION

- EXTENT OF THE ENTRADA SANDSTONE

-6800- LINE OF EQUAL COMPUTED STEADY-STATE HEAD.-

sea level. Contour interval 200 feet

STUDY AREA BOUNDARY

Figure 53.--Computed steady-state head in the Entrada Sandstone. 


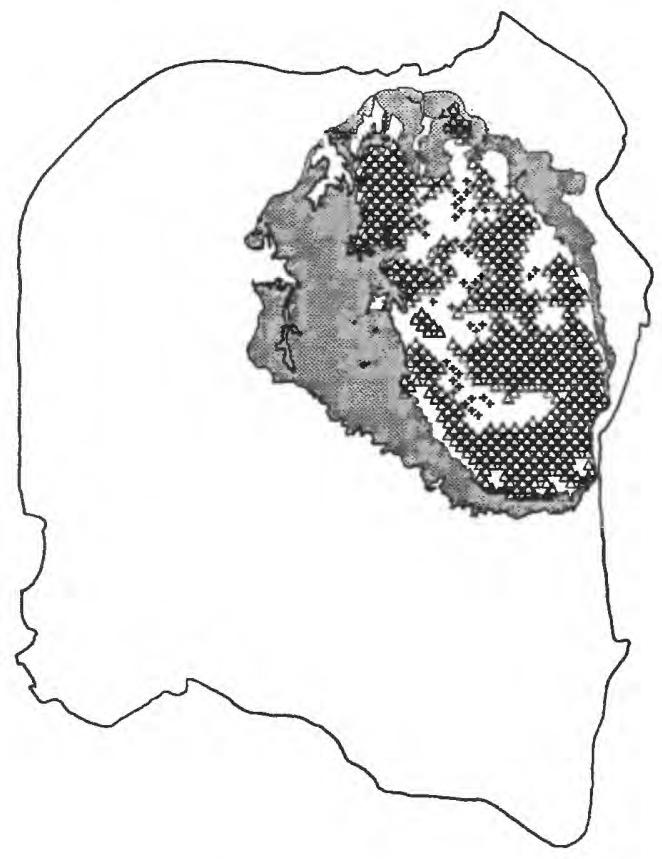

A. Vertical flow directions between the San Jose and the Animas and Nacimiento Formations.

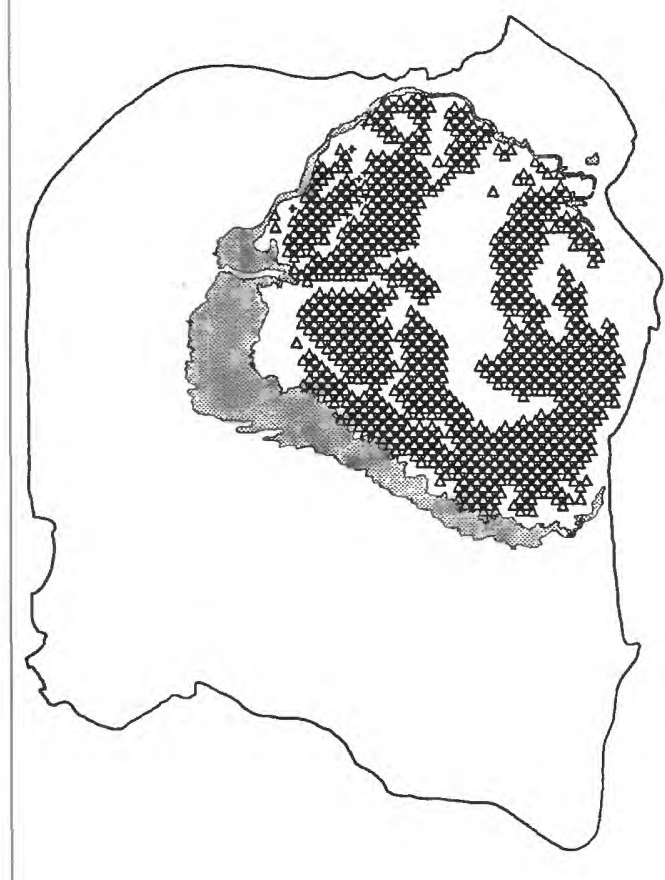

B. Vertical flow directions between the Animas and Nacimiento Formations and the combined Ojo Alamo, Kirtland Shale, and Fruitland Formation.

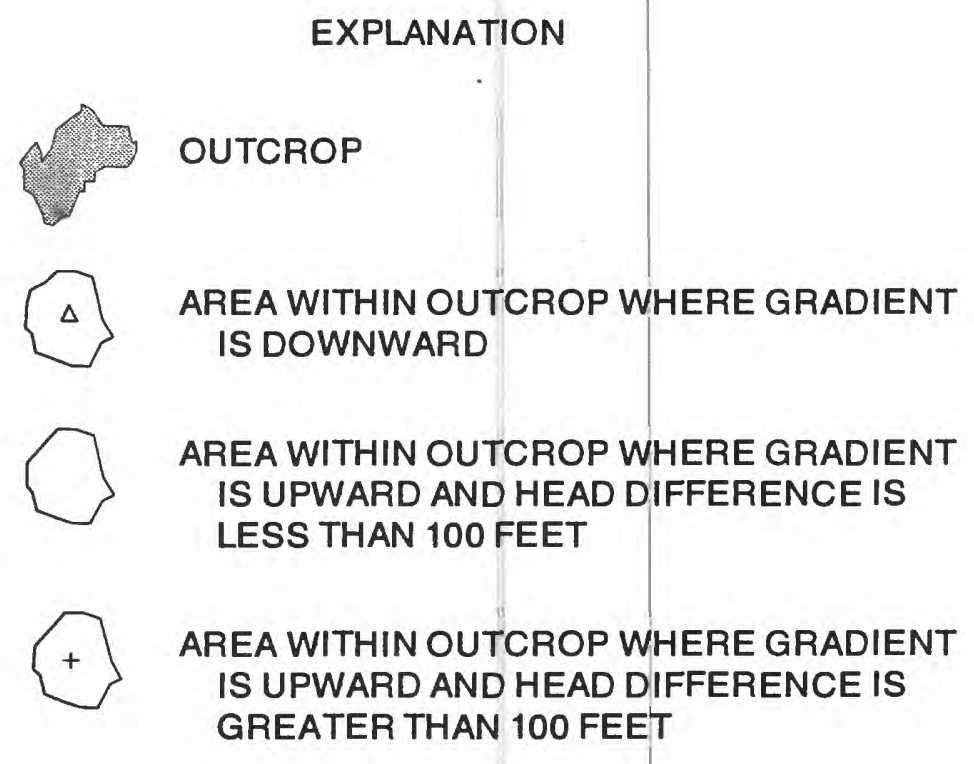

Figure 54.--Vertical flow directions between selected adjacent hydrostratigraphic units in the San Juan Basin. 


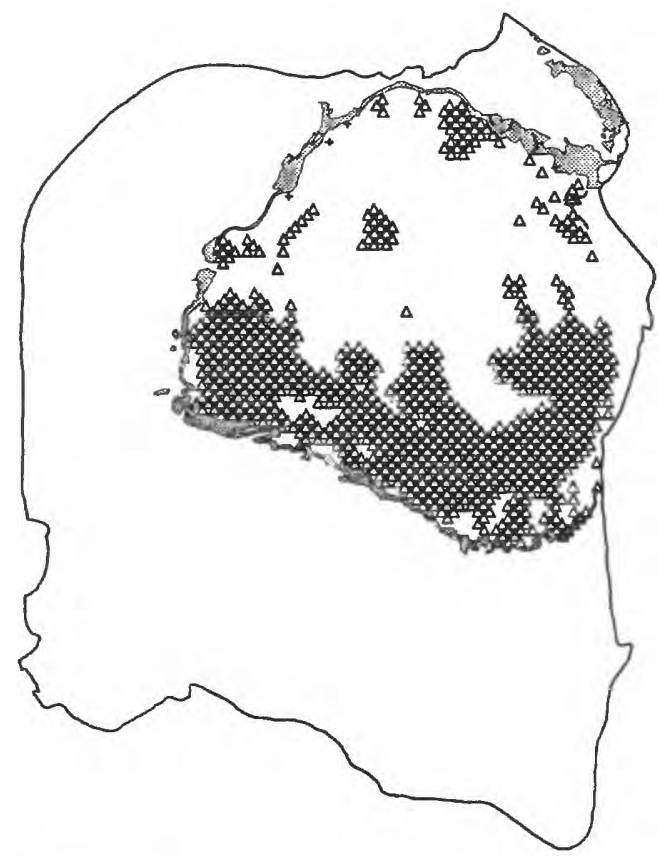

C. Vertical flow directions between the combined Ojo Alamo, Kirtland Shale, and Fruitland Formation and the Pictured Cliffs Sandstone.

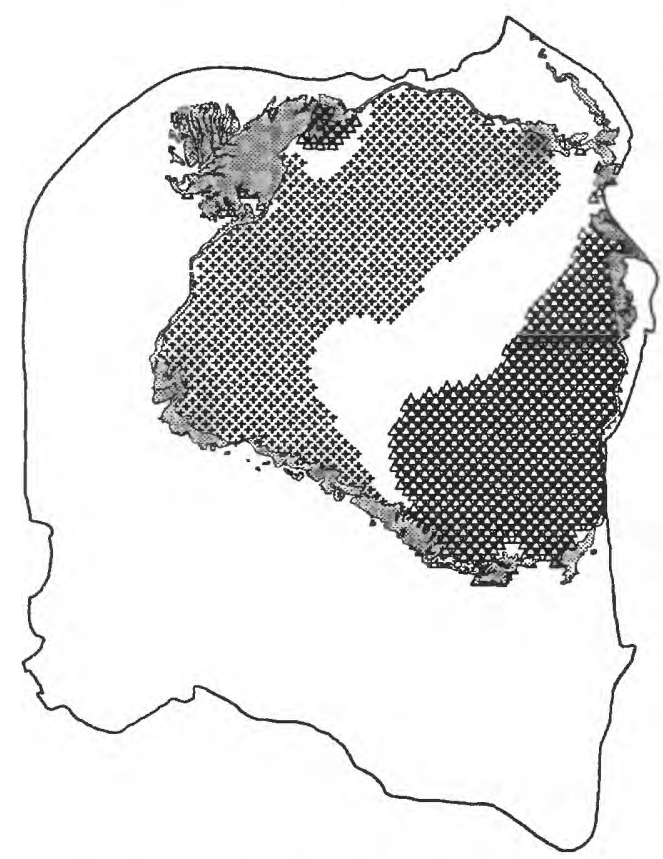

E. Vertical flow directions between the Cliff House Sandstone and the Point Lookout Sandstone.

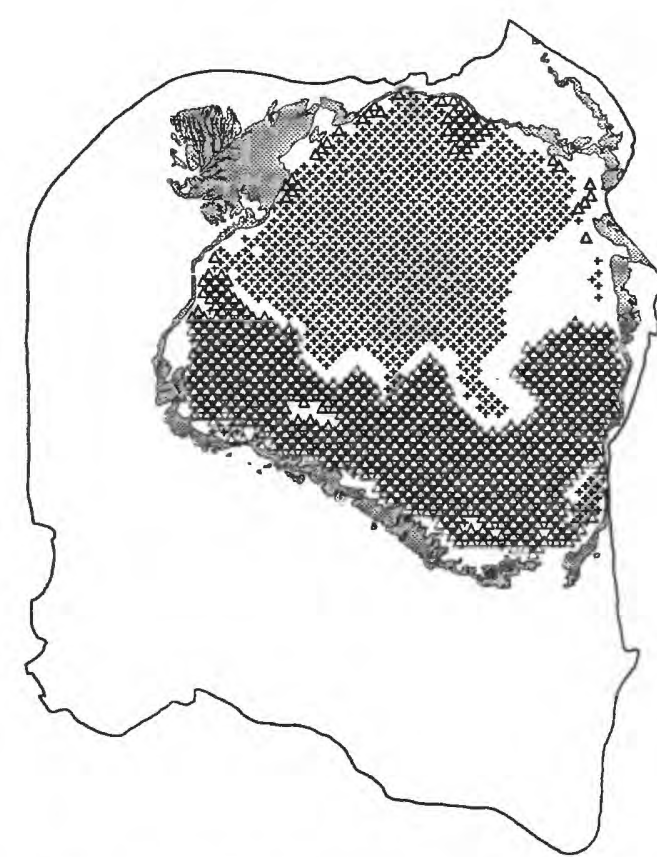

D. Vertical flow directions between the Pictured Cliffs Sandstone and the Cliff House Sandstone.

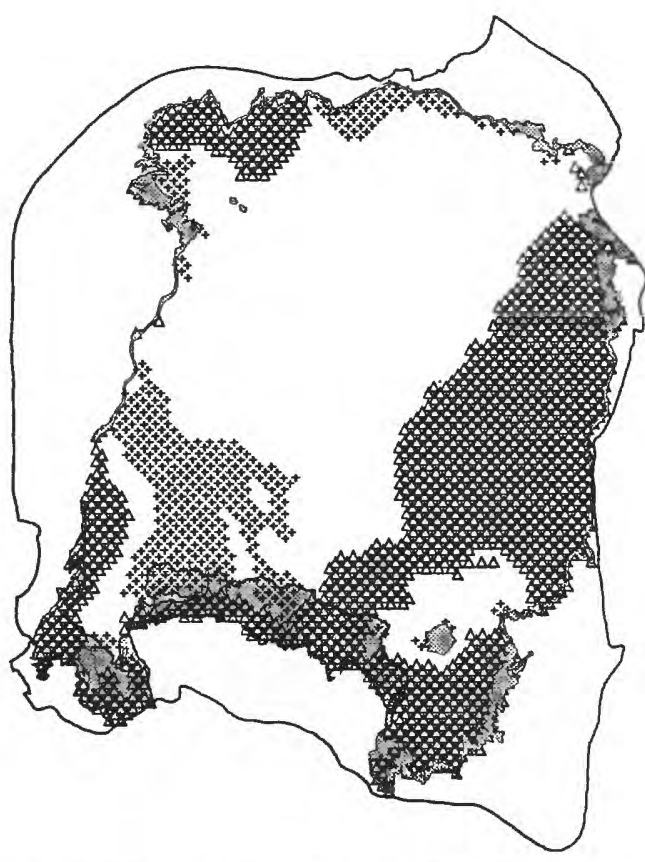

F. Vertical flow directions between the Point Lookout Sandstone and the Gallup Sandstone.

Figure 54.--Vertical flow directions between selected adjacent hydrostratigraphic units in the San Juan Basin--Continued. 


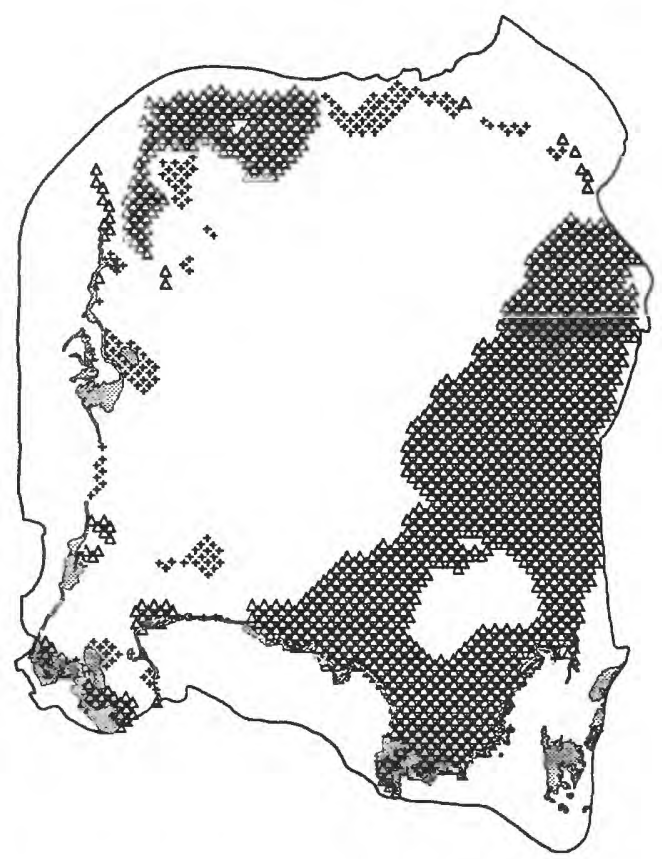

G. Vertical flow directions between the Gallup Sandstone and the Dakota Sandstone.

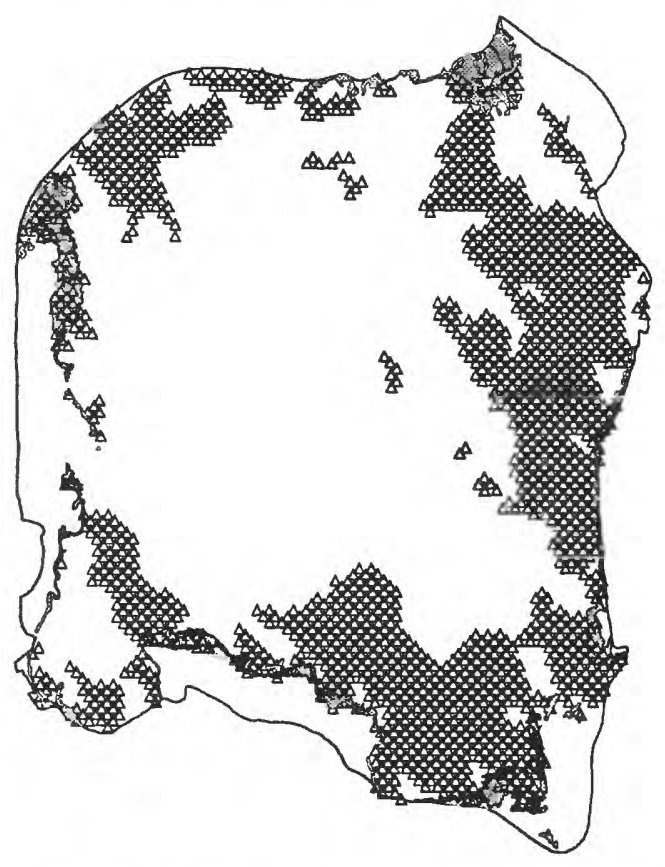

1. Vertical flow directions between the Morrison Formation and the Entrada Sandstone.

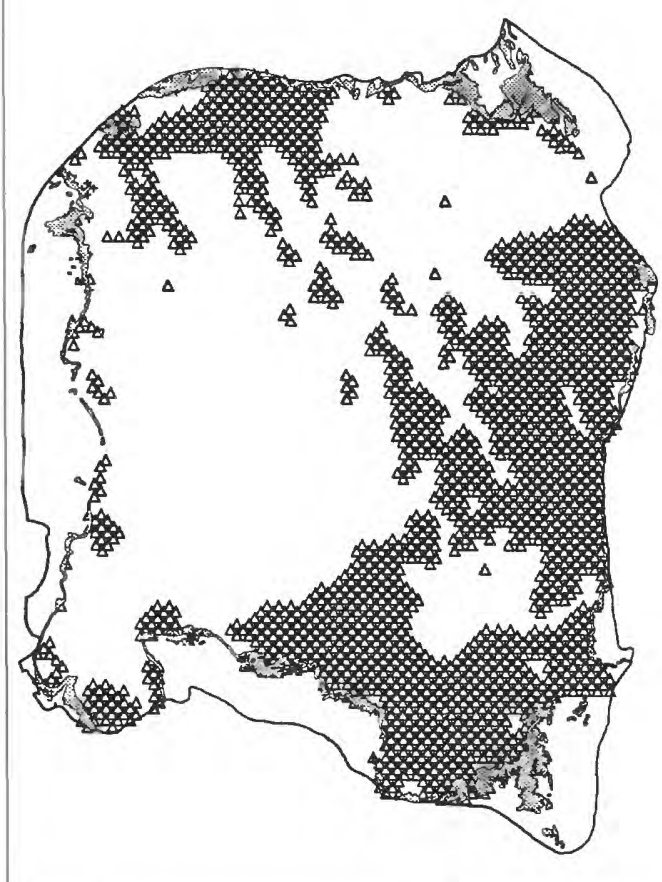

H. Vertical flow directions between the Dakota Sandstone and the Morrison Formation.

Figure 54.-- Vertical flow directions between selected adjacent hydrostratigraphic units in the San Juan Basin--Concluded. 
The computed mass balance for water in the ground-water-flow system indicates that the aquifers in the regional system gain 135 cubic feet per second from streambed infiltration, 56 cubic feet per second from direct precipitation, and 4 cubic feet per second from downward leakage from the Chuska Sandstone. The 56 cubic feet per second computed recharge from direct precipitation is roughly one-third of the estimate presented earlier. Because the method used to develop the previous estimate did not differentiate between distributed recharge and local stream losses, however, comparing that estimate with the total computed gain from both streams and direct recharge, about 191 cubic feet per second, is more appropriate.

The total steady-state outflow from the aquifer system is computed to be 195 cubic feet per second, which basinwide is equivalent to 0.14 inch per year or about 1 percent of the average annual precipitation in the basin. All of this is simulated as being discharged to the surface-water system, primarily to the lower reaches of the San Juan and Puerco Rivers and the Rio Puerco. Under steady-state conditions inflow equals outflow. However, when the aquifer system is stressed by withdrawal of water this equilibrium is disrupted: recharge to the system increases and natural discharge from it decreases. Because of the probability of induced recharge to the system in response to ground-water withdrawals, the ground-water system should not be thought of as limited to its computed equilibrium flux of 195 cubic feet per second.

\section{SUMMARY AND CONCLUSIONS}

As part of the RASA program a three-dimensional steady-state ground-water-flow model was constructed for the San Juan structural basin in parts of New Mexico, Colorado, Arizona, and Utah. The model encompassed an area of about 19,380 square miles and simulated steady-state ground-water flow in 12 hydrostratigraphic units representing all major sources of ground water from aquifers of Jurassic and younger age.

The geohydrology of 10 of the 12 hydrostratigraphic units previously was described in a series of Hydrologic Investigations Atlases (U.S. Geological Survey HA-720 series). Information presented in the atlases and in this report was processed and stored in digital GIS data bases. The same data bases that were used to prepare the atlases were used to supply geohydrologic data to the ground-water-flow model. The digital data supplied from the GIS included tops and bottoms of units; land-surface altitude; areas of outcrop; locations, widths, altitudes, and vertical hydraulic conductivities of streams and streambeds; and areal distribution and rate of distributed recharge. Additionally, the GIS was used to construct model-input arrays of horizontal hydraulic conductivity and vertical hydraulic conductance.

Stream-aquifer interaction, direct recharge from precipitation, and downward leakage from the Chuska Sandstone were the external boundary conditions that were simulated. Streambed leakage contributed 135 cubic feet per second to the aquifer system, direct recharge contributed 56 cubic feet per second, and downward leakage from the Chuska Sandstone contributed 4 cubic feet per second. A computed discharge of 195 cubic feet per second to the lower reaches of the major streams and rivers in the basin balanced the steady-state water budget of the ground-waterflow system. The total steady-state outflow from the aquifer system is computed to be 195 cubic feet per second, which basinwide is equivalent to 0.14 inch per year or about 1 percent of the average annual precipitation in the basin.

Outcrop boundary conditions were found to most strongly control hydraulic heads and head distributions in the San Juan Basin. Less significant in the simulations were the simulated horizontal hydraulic-conductivity values, and least significant were the simulated horizontal anisotropy and vertical hydraulic-conductivity values. 


\section{SELECTED REFERENCES}

Allen, J.E., and Balk, Robert, 1954, Mineral resources of the Fort Defiance and Tohatchi quadrangles, Arizona and New Mexico: Socorro, New Mexico Bureau of Mines and Mineral Resources Bulletin 36, 192 p.

Anderholm, S.K., 1979, Hydrogeology and water resources of the Cuba quadrangle, Sandoval and Rio Arriba Counties, New Mexico: Socorro, New Mexico Institute of Mining and Technology, unpublished M.S. thesis, $162 \mathrm{p}$.

Baltz, E.H., 1967, Stratigraphy and regional tectonic implications of part of Upper Cretaceous rocks, east-central San Juan Basin, New Mexico: U.S. Geological Survey Professional Paper 552, $101 \mathrm{p}$.

Baltz, E.H., Ash, S.R., and Anderson, R.Y., 1966, History of nomenclature and stratigraphy of rocks adjacent to the Cretaceous-Tertiary boundary, western San Juan Basin, New Mexico: U.S. Geological Survey Professional paper 524-D, 23 p.

Baltz, E.H., and West, S.W., 1967, Ground-water resources of the southern part of Jicarilla Apache Indian Reservation and adjacent areas, New Mexico: U.S. Geological Survey Water-Supply Paper 1576-H, 89 p.

Barnes, Harley, Baltz, E.H., Jr., and Hayes, P.T., 1954, Geology and fuel resources of the Red Mesa area, La Plata and Montezuma Counties, Colorado: U.S. Geological Survey Oil and Gas Investigations Map OM-149, 1 sheet, scale 1:62,500.

Bauer, C.M., 1916, Stratigraphy of a part of the Chaco River valley, in Contributions to the geology and paleontology of San Juan County, New Mexico: U.S. Geological Survey Professional Paper 98-P, p. 271-278.

Beaumont, E.C., 1971, Stratigraphic distribution of coal in San Juan Basin, in Shomaker, J.W., Beaumont, E.C., and Kottlowski, F.E., eds., Strippable low-sulfur coal resources of the San Juan Basin in New Mexico and Colorado: Socorro, New Mexico Bureau of Mines and Mineral Resources Memoir 25, p. 15-30.

Beaumont, E.C., Dane, C.H., and Sears, J.D., 1956, Revised nomenclature of Mesaverde Group in San Juan Basin, New Mexico: American Association of Petroleum Geologists Bulletin, v. 40, no. 9, p. 2149-2162.

Brimhall, R.M., 1973, Ground-water hydrology of Tertiary rocks of the San Juan Basin, New Mexico, in Fassett, J.E., ed., Cretaceous and Tertiary rocks of the southern Colorado Plateau: Four Corners Geological Society Memoir, p. 197-207.

Cadigan, R.A., 1967, Petrology of the Morrison Formation in the Colorado Plateau region: U.S. Geological Survey Professional Paper 556, 113 p.

Chow, V.T., 1964, Handbook of applied hydrology, a compendium of water-resources technology: New York, McGraw-Hill Book Company, 1418 p.

Collier, A.J., 1919, Coal south of Mancos, Montezuma County, Colorado: U.S. Geological Survey Bulletin 691-K, p. 293-310. 


\section{SELECTED REFERENCES--Continued}

Condon, S.M., 1989, Modifications to Middle and Upper Jurassic nomenclature in the southeastern San Juan Basin, New Mexico, in Guidebook of Southeastern Colorado Plateau: New Mexico Geological Society, 40th Field Conference, p. 231-238.

Condon, S.M., and Huffman, A.C., Jr., 1988, Revisions in nomenclature of the Middle Jurassic Wanakah Formation, northwest New Mexico and northeast Arizona: U.S. Geological Survey Bulletin 1633-A, p. 1-12.

Condon, S.M., and Peterson, Fred, 1986, Stratigraphy of Middle and Upper Jurassic rocks of the San Juan Basin--Historical perspective, current ideas, and remaining problems, in TurnerPeterson, C.E., Santos, E.S., and Fishman, N.S., eds., 1986, A basin analysis case study-The Morrison Formation, Grants uranium region, New Mexico: American Association of Petroleum Geologists Studies in Geology, no. 22, p. 7-26.

Craig, L.C., Holmes, C.N., Cadigan, R.A., Freeman, V.L., Mullens, T.E., and Weir, G.W., 1955, Stratigraphy of the Morrison and related formations, Colorado Plateau region--A preliminary report: U.S. Geological Survey Bulletin 1009-E, p. 125-168.

Craigg, S.D., 1980, Hydrogeology and water resources of the Chico Arroyo/Torreon Wash area, Sandoval and McKinley Counties, New Mexico: Socorro, New Mexico Institute of Mining and Technology, unpublished M.S. thesis, $272 \mathrm{p}$.

1984, Hydrologic data on the Pueblos of Jemez, Zia, and Santa Ana, Sandoval County, New Mexico: U.S. Geological Survey Open-File Report 84-460, 37 p.

in press, Geologic framework of the San Juan structural basin of New Mexico, Colorado, Arizona, and Utah, with emphasis on Triassic through Tertiary rocks: U.S. Geological Survey Professional Paper 1420.

Craigg, S.D., Dam, W.L., Kernodle, J.M., and Levings, G.W., 1989, Hydrogeology of the Dakota Sandstone in the San Juan structural basin, New Mexico, Colorado, Arizona, and Utah: U.S. Geological Survey Hydrologic Investigations Atlas HA-720-I, 2 sheets.

Craigg, S.D., Dam, W.L., Kernodle, J.M., Thorn, C.R., and Levings, G.W., 1990, Hydrogeology of the Point Lookout Sandstone in the San Juan structural basin, New Mexico, Colorado, Arizona, and Utah: U.S. Geological Survey Hydrologic Investigations Atlas HA-720-G, 2 sheets.

Dam, W.L., 1995, Geochemistry of ground water in the Gallup, Dakota, and Morrison aquifers, San Juan Basin, New Mexico: U.S. Geological Survey Water-Resources Investigations Report 94-4253, 76 p.

Dam, W.L., Kernodle, J.M., Levings, G.W., and Craigg, S.D., 1990a, Hydrogeology of the Morrison Formation in the San Juan structural basin, New Mexico, Colorado, Arizona, and Utah: U.S. Geological Survey Hydrologic Investigations Atlas HA-720-J, 2 sheets.

Dam, W.L., Kernodle, J.M., Thorn, C.R., Levings, G.W., and Craigg, S.D., 1990b, Hydrogeology of the Pictured Cliffs Sandstone in the San Juan structural basin, New Mexico, Colorado, Arizona, and Utah: U.S. Geological Survey Hydrologic Investigations Atlas HA-720-D, 2 sheets. 


\section{SELECTED REFERENCES--Continued}

Dames and Moore, 1977, Geotechnical and hydrologic investigation, production shaft 1, mining unit 1, Nose Rock project: Consultant's report for Phillips Petroleum Company, 56 p.

Dane, C.H., 1936, The La Ventana-Chacra Mesa coal field, in The geology of fuels in the southern part of the San Juan Basin, New Mexico: U.S. Geological Survey Bulletin 860-C, p. 81-161.

Dane, C.H., and Bachman, G.O., 1965, Geologic map of New Mexico: U.S. Geological Survey, 2 sheets, scale 1:500,000.

Dane, C.H., Bachman, G.O., and Reeside, J.B., Jr., 1957, The Gallup Sandstone, its age and stratigraphic relationships south and east of the stratotype, in Little, C.J., and Gill, J.J., eds., Guidebook to geology of southwestern San Juan Basin: Four Corners Geological Society, Second Field Conference, p. 99-113.

Darcy, H., 1856, Les fontaines publiques de la ville de Dijon: Paris, Victor Dalmont, $647 \mathrm{p}$.

Davies, P.B., 1989, Variable-density ground-water flow and paleohydrology in the Waste Isolation Pilot Plant (WIPP) region, southeastern New Mexico: U.S. Geological Survey Open-File Report 88-490, $139 \mathrm{p}$.

Dutton, C.E., 1885, Mount Taylor and the Zuni Plateau, in Sixth Annual Report: U.S. Geological Survey, p. 105-198.

Emery, P.A., 1970, Electric analog model evaluation of a water-salvage plan, San Luis Valley, south-central Colorado: Colorado Water Conservation Board Water Resources Circular 14, $11 \mathrm{p}$.

Fassett, J.E., 1974, Cretaceous and Tertiary rocks of the eastern San Juan Basin, New Mexico and Colorado, in Guidebook of Ghost Ranch, central-northern New Mexico: New Mexico Geological Society, 25th Field Conference, p. 225-230.

1977, Geology of the Point Lookout, Cliff House, and Pictured Cliffs Sandstones of the San Juan Basin, New Mexico and Colorado, in Fassett, J.E., ed., Guidebook of San Juan Basin III, northwestern New Mexico: New Mexico Geological Society, 28th Field Conference, p. 193-197.

1989, Coal-bed methane--A contumaceous, free-spirited bride, the geologic handmaiden of coal beds, in Energy Frontiers in the Rockies: Albuquerque Geological Society, New Mexico, p. 131-146.

Fassett, J.E., and Hinds, J.S., 1971, Geology and fuel resources of the Fruitland Formation and Kirtland Shale of the San Juan Basin, New Mexico and Colorado: U.S. Geological Survey Professional Paper 676, $76 \mathrm{p}$.

Fassett, J.E., Jentgen, R.W., Black, B.A., Molenaar, C.M., and Woodward, L.A., 1977, Road log second day: Red Mountain Oil Field to El Vado Lake via Pueblo Pintado, Star Lake, Torreon, Cuba, and Llaves, in Fassett, J.E., ed., Guidebook to San Juan Basin III: New Mexico Geological Society, 28th Field Conference, p. 19-38.

Freeze, R.A., and Cherry, J.A., 1979, Groundwater: Englewood Cliffs, N.J., Prentice-Hall, Inc., $604 \mathrm{p}$. 


\section{SELECTED REFERENCES--Continued}

Frenzel, P.F., 1982, Estimates of vertical hydraulic conductivity and regional ground-water flow rates in rocks of Jurassic and Cretaceous age, San Juan Basin, New Mexico and Colorado: U.S. Geological Survey Water-Resources Investigations Report 82-4015, 59 p.

1983, Simulated changes in ground-water levels related to proposed development of Federal coal leases, San Juan Basin, New Mexico: U.S. Geological Survey Open-File Report 83-949, 63 p.

Freyberg, D.L., 1988, An exercise in ground-water model calibration and prediction: Ground Water, v. 26, no. 3, p. 350-360.

Fuchs-Parker, J.W., 1977, Alibi for a Mesaverde misfit--The La Ventana Formation Cretaceous delta, New Mexico, in Fassett, J.E., ed., Guidebook of San Juan Basin III, northwestern New Mexico: New Mexico Geological Society, 28th Field Conference, p. 199-206.

Gilluly, James, and Reeside, J.B., Jr., 1928, Sedimentary rocks of the San Rafael swell and some adjacent areas in eastern Utah: U.S. Geological Survey Professional Paper 150-D, p. 61-110.

Green, M.W., and Pierson, C.T., 1977, A summary of the stratigraphy and depositional environments of Jurassic and related rocks in the San Juan Basin, Arizona, Colorado, and New Mexico, in Fassett, J.E., ed.,Guidebook of San Juan Basin III: New Mexico Geological Society, 28th Field Conference, p. 147-152.

Gregory, H.E., 1938, The San Juan country--A geographic and geologic reconnaissance of southeastern Utah: U.S. Geological Survey Professional Paper 188, 123 p.

Harshbarger, J.W., and Repenning, C.A., 1954, Water resources of the Chuska Mountains area, Navajo Indian Reservation, Arizona and New Mexico: U.S. Geological Survey Circular 308, 16 p.

Haynes, D.D., Vogel, J.D., and Wyant, D.G., 1972, Geology, structure, and uranium deposits of the Cortez quadrangle, Colorado and Utah: U.S. Geological Survey Miscellaneous Geologic Investigations Map I-629, 2 sheets, scale 1:250,000.

Hearne, G.A., 1977, Evaluation of a potential well field near Church Rock as a water supply for Gallup, New Mexico: U.S. Geological Survey Water-Resources Investigations Report 7798, $26 \mathrm{p}$.

1985, Mathematical model of the Tesuque aquifer system near Pojoaque, New Mexico: U.S. Geological Survey Water-Supply Paper 2205, 75 p.

Hearne, G.A., and Dewey, J.D., 1988, Hydrologic analysis of the Rio Grande Basin north of Embudo, New Mexico, Colorado and New Mexico: U.S. Geological Survey WaterResources Investigations Report 86-4113, 244 p.

Hem, J.D., 1985, Study and interpretation of the chemical characteristics of natural water (3d ed., rev.): U.S. Geological Survey Water-Supply Paper 2254, 263 p.

Heywood, C.E., 1990, Use of a geographic information system in the analysis of geophysical and geologic data for ground-water basin studies in New Mexico [abs.], in Transactions, American Geophysical Union, v. 71, no. 43, October 23, 1990, p. 1316. 


\section{SELECTED REFERENCES--Continued}

Heywood, C.E., 1991, Isostatic residual gravity anomalies of New Mexico: U.S. Geological Survey Water-Resources Investigations Report 91-4065, 27 p.

Hintze, L.F., 1981, Geologic map of Utah: Utah Geological and Mineral Survey, 1 sheet, scale $1: 500,000$.

Holmes, W.H., 1877, Report of the San Juan district, Colorado: U.S. Geological and Geographical Survey Territories, Ninth Annual Report (1875), p. 237-276.

Horn, C.R., 1986, Reach-file manual: U.S. Environmental Protection Agency, Washington, D.C., $40 \mathrm{p}$.

Kelley, V.C., 1951, Tectonics of the San Juan Basin, in Guidebook of the south and west sides of the San Juan Basin, New Mexico and Arizona: New Mexico Geological Society, Second Field Conference, p. 124-131.

Kelly, T.E., 1977, Geohydrology of the Westwater Canyon Member, Morrison Formation, of the southern San Juan Basin, New Mexico, in Fassett, J.E., ed., Guidebook of San Juan Basin III, northwestern New Mexico: New Mexico Geological Society, 28th Field Conference, p. 285-290.

Kernodle, J.M., 1992, Summary of U.S. Geological Survey ground-water-flow models of basinfill aquifers in the Southwest Alluvial Basins region, Colorado, New Mexico, and Texas: U.S. Geological Survey Open-File Report 90-361, 81 p.

Kernodle, J.M., Levings, G.W., Craigg, S.D., and Dam, W.L., 1989, Hydrogeology of the Gallup Sandstone in the San Juan structural basin, New Mexico, Colorado, Arizona, and Utah: U.S. Geological Survey Hydrologic Investigations Atlas HA-720-H, 2 sheets.

Kernodle, J.M., and Philip, R.D., 1988, Using a geographic information system to develop a ground-water flow model, in Regional aquifer systems of the United States, aquifers of the western mountain area: American Water Resources Association Monograph 14, p. 191-202.

Kernodle, J.M., Thorn, C.R., Levings, G.W., Craigg, S.D., and Dam, W.L., 1990, Hydrogeology of the Kirtland Shale and Fruitland Formation in the San Juan structural basin, New Mexico, Colorado, Arizona, and Utah: U.S. Geological Survey Hydrologic Investigations Atlas HA-720-C, 2 sheets.

Klausing, R.L., and Welder, G.E., 1983, Data for ground-water studies of the San Juan Basin, New Mexico (1982-83): U.S. Geological Survey Open-File Report 84-135, 46 p.

Knight, R.L., and Cooper, J.C., 1955, Suggested changes in Devonian terminology of the Four Corners area, in Guidebook to Four Corners: Four Corners Geological Society, First Field Conference, p. 56-58.

Landis, E.R., Dane, C.H., and Cuban, W.A., 1973, Stratigraphic terminology of the Dakota Sandstone and Mancos Shale, west-central New Mexico: U.S. Geological Survey Bulletin 1372-J, 44 p.

Levings, G.W., Craigg, S.D., Dam, W.L., Kernodle, J.M., and Thorn, C.R., 1990a, Hydrogeology of the Menefee Formation in the San Juan structural basin, New Mexico, Colorado, Arizona, and Utah: U.S. Geological Survey Hydrologic Investigations Atlas HA-720-F, 2 sheets. 


\section{SELECTED REFERENCES--Continued}

Levings, G.W., Craigg, S.D., Dam, W.L., Kernodle, J.M., and Thorn, C.R., 1990b, Hydrogeology of the San Jose, Nacimiento, and Animas Formations in the San Juan structural basin, New Mexico, Colorado, Arizona, and Utah: U.S. Geological Survey Hydrologic Investigations Atlas HA-720-A, 2 sheets.

Levings, G.W., Kernodle, J.M., and Thorn, C.R., 1996, Summary of the San Juan structural basin Regional Aquifer-System Analysis, New Mexico, Colorado, Arizona, and Utah: U.S. Geological Survey Water-Resources Investigations Report 95-4188, 55 p.

Lohman, S.W., 1972, Ground-water hydraulics: U.S. Geological Survey Professional Paper 708, $70 \mathrm{p}$.

Mannhard, G.W., 1976, Stratigraphy, sedimentology, and paleoenvironments of the La Ventana Tongue (Cliff House Sandstone) and adjacent formations of the Mesaverde Group (Upper Cretaceous), southwestern San Juan Basin, New Mexico: Albuquerque, University of New Mexico, unpublished Ph.D. dissertation, $182 \mathrm{p}$.

McDonald, M.G., and Harbaugh, A.W., 1988, A modular three-dimensional finite-difference ground-water flow model: U.S. Geological Survey Techniques of Water-Resources Investigations, book 6, chap. A1, 548 p.

McLean, J.S., 1980, Aquifer tests in the Gallup Sandstone near Yah-Ta-Hey, New Mexico: U.S. Geological Survey Water-Resources Investigations 80-25, 25 p.

Mercer, J.W., 1969, Hydrology of Project Gasbuggy site, Rio Arriba County, New Mexico: U.S. Geological Survey Report PNE-1013, 45 p.

Merrick, M.A., 1980, Geology of the eastern part of the Regina quadrangle, Sandoval and Rio Arriba Counties, New Mexico: Albuquerque, University of New Mexico, unpublished M.S. thesis, $91 \mathrm{p}$.

Molenaar, C.M., 1973, Sedimentary facies and correlation of the Gallup Sandstone and associated formations, northwestern New Mexico, in Cretaceous and Tertiary rocks of southern Colorado Plateau: Four Corners Geological Society Memoir, p. 85-110.

1974, Correlation of the Gallup Sandstone and associated formations, Upper Cretaceous, eastern San Juan and Acoma basins, New Mexico, in Siemers, C.T., ed., Guidebook of Ghost Ranch, central-northern New Mexico: New Mexico Geological Society, 25th Field Conference, p. 251-258.

1977a, San Juan Basin time-stratigraphic nomenclature chart, in Fassett, J.E., ed., Guidebook of San Juan Basin III: New Mexico Geological Society, 28th Field Conference, p. xii.

1977b, Stratigraphy and depositional history of Upper Cretaceous rocks of the San Juan Basin area, New Mexico and Colorado, with a note on Economic resources, in Fassett, J.E., ed., Guidebook of San Juan Basin III: New Mexico Geological Society, 28th Field Conference, p. 159-166.

1989, San Juan Basin stratigraphic correlation chart, in Finch, W.I., Huffman, A.C., Jr., and Fassett, J.E., eds., Coal, uranium, and oil and gas in Mesozoic rocks of the San Juan Basin-Anatomy of a giant energy-rich basin: 28th International Geological Congress, Washington, D.C., Guidebook for Field Trip T120, p. xi. 


\section{SELECTED REFERENCES--Continued}

Myers, R.G., and Villanueva, E.D., 1986, Geohydrology of the aquifers that may be affected by the surface mining of coal in the Fruitland Formation in the San Juan Basin, northwestern New Mexico: U.S. Geological Survey Water-Resources Investigations Report 85-4251, $41 \mathrm{p}$.

National Oceanic and Atmospheric Administration, n.d., Annual free water surface evaporation: National Oceanic and Atmospheric Administration Technical Report NWS33, Map 3, scale $1: 5,000,000$.

Noon, P.L., 1980, Surface to subsurface stratigraphy of the Dakota Sandstone (Cretaceous) and adjacent units along the eastern flank of the San Juan Basin, New Mexico and Colorado: Bowling Green, Ohio, Bowling Green State University, unpublished M.S. thesis, 113 p.

O'Brien, K.M., and Stone, W.J., 1983, A two-dimensional hydrologic model of the Animas Valley, Hidalgo County, New Mexico: Socorro, New Mexico Bureau of Mines and Mineral Resources Open-File Report 133, 60 p.

O'Sullivan, R.B., and Beikman, H.M., 1963, Geology, structure, and uranium deposits of the Shiprock quadrangle, New Mexico and Arizona: U.S. Geological Survey Miscellaneous Geologic Investigations Map I-345, 2 sheets, scale 1:250,000.

O'Sullivan, R.B., Repenning, C.A., Beaumont, E.C., and Page, H.G., 1972, Stratigraphy of the Cretaceous rocks and the Tertiary Ojo Alamo Sandstone, Navajo and Hopi Indian Reservations, Arizona, New Mexico, and Utah: U.S. Geological Survey Professional Paper 521-E, $65 \mathrm{p}$.

Owen, D.E., 1973, Depositional history of the Dakota Sandstone, San Juan Basin area, New Mexico, in Fassett, J.E., ed., Cretaceous and Tertiary rocks of the southern Colorado Plateau: Four Corners Geological Society Memoir, p. 37-51.

1984, The Jackpile Sandstone Member of the Morrison Formation in west-central New Mexico--A formal definition: New Mexico Geology, v. 6, no. 3, p. 45-52.

Owen, D.E., and Siemers, C.T., 1977, Lithologic correlation of the Dakota Sandstone and adjacent units along the eastern flank of the San Juan Basin, New Mexico, in Fassett, J.E., ed., Guidebook of San Juan Basin III, northwestern New Mexico: New Mexico Geological Society, 28th Field Conference, p. 179-183.

Peeters, L.A., 1983, An isotopic investigation of ground-water resources in the Ojo Alamo Sandstone, San Juan Basin: Socorro, New Mexico Institute of Mining and Technology, unpublished M.S. thesis, $104 \mathrm{p}$.

Pentilla, W.C., 1964, Evidence for the pre-Niobrara unconformity in the northwestern part of the San Juan Basin: The Mountain Geologist, v. 1, p. 3-14.

Peter, K.D., Williams, R.A., and King, K.W., 1987, Hydrogeologic characteristics of the Lee Acres landfill area, San Juan County, New Mexico: U.S. Geological Survey WaterResources Investigations Report 87-4246, 69 p.

Phillips, F.M., Peeters, L.A., Tansey, M.K., and Davis, S.N., 1986, Paleoclimatic inferences from an isotopic investigation of groundwater in the central San Juan Basin, New Mexico: Quaternary Research, v. 26, p. 179-193. 


\section{SELECTED REFERENCES--Continued}

Powell, J.S., 1973, Paleontology and sedimentation models of the Kimbeto Member of the Ojo Alamo Sandstone: Four Corners Geological Society Memoir, p. 111-122.

Reeside, J.B., Jr., 1924, Upper Cretaceous and Tertiary formations of the western part of the San Juan Basin, Colorado and New Mexico, and Flora and fauna of the Animas Formation, by F.H. Knowlton: U.S. Geological Survey Professional Paper 134, 117 p.

Reneau, W.E., Jr., and Harris, J.D., 1957, Reservoir characteristics of Cretaceous sands of the San Juan Basin, in Little, C.J., and Gill, J.J., eds., Guidebook to geology of southwestern San Juan Basin: Four Corners Geological Society, Second Field Conference, p. 40-43.

Risser, D.W., Davis, P.A., Baldwin, J.A., and McAda, D.P., 1984, Aquifer tests at the JackpilePaguate uranium mine, Pueblo of Laguna, west-central New Mexico: U.S. Geological Survey Water-Resources Investigations Report 84-4255, 26 p.

Risser, D.W., and Lyford, P.F., 1983, Water resources on the Pueblo of Laguna, west-central New Mexico: U.S. Geological Survey Water-Resources Investigations Report 83-4038, 108 p.

Robinove, C.J., 1986, Principles of logic and the use of digital geographic information systems: U.S. Geological Survey Circular 977, 19 p.

Sanford, R.F., 1989, Late Jurassic paleohydrology of San Juan Basin--Simulated effects of variable transmissivity and lake levels [abs.]: Proceedings, American Association of Petroleum Geologists 1989 Rocky Mountain Section Meeting, Albuquerque, N. Mex., October 1-4, 1989, p. 90.

Sears, J.D., 1925, Geology and coal resources of the Gallup-Zuni Basin, New Mexico: U.S. Geological Survey Bulletin 767, 53 p.

Sears, J.D., Hunt, C.B., and Dane, C.H., 1936, Geology and fuel resources of the southern part of the San Juan Basin, New Mexico: U.S. Geological Survey Bulletin 860, 166 p.

Sears, J.D., Hunt, C.B., and Hendricks, T.A., 1941, Transgressive and regressive Cretaceous deposits in southern San Juan Basin, New Mexico, in Shorter contributions to general geology, 1938-40: U.S. Geological Survey Professional Paper 193-F, p. 101-121.

Shetiwy, M.M., 1978, Sedimentologic and stratigraphic analysis of the Point Lookout Sandstone, southeastern San Juan Basin, New Mexico: Socorro, New Mexico Institute of Mining and Technology, unpublished Ph.D. dissertation, 262 p.

Simpson, G.G., 1948a, The Eocene of the San Juan Basin, New Mexico: American Journal of Science, v. 246, pt. 1, p. 257-282.

1948b, The Eocene of the San Juan Basin, New Mexico: American Journal of Science, v. 246, pt. 2, p. 363-385.

Steven, T.A., Lipman, P.W., Hail, W.J., Jr., Barker, Fred, and Luedke, R.G., 1974, Geologic map of the Durango quadrangle, southwestern Colorado: U.S. Geological Survey Miscellaneous Investigations Map I-764, 1 sheet, scale 1:250,000.

Stone, W.J., Lyford, F.P., Frenzel, P.F., Mizell, N.H., and Padgett, E.T., 1983, Hydrogeology and water resources of San Juan Basin, New Mexico: Socorro, New Mexico Bureau of Mines and Mineral Resources Hydrologic Report 6, 70 p. 


\section{SELECTED REFERENCES--Continued}

Sun, R.J., ed., 1986, Regional Aquifer-System Analysis program of the U.S. Geological Survey, summary of projects, 1978-84: U.S. Geological Survey Circular 1002, 264 p.

Tabet, D.E., and Frost, S.J., 1979, Environmental characteristics of Menefee coals in the Torreon Wash area, New Mexico: Socorro, New Mexico Bureau of Mines and Mineral Resources Open-File Report 102, 134 p.

Thomas, B.E., 1989, Simulation of the ground-water system in Mesozoic rocks in the Four Corners area, Utah, Colorado, Arizona, and New Mexico: U.S. Geological Survey WaterResources Investigations Report 88-4086, 89 p.

Thorn, C.R., Levings, G.W., Craigg, S.D., Dam, W.L., and Kernodle, J.M., 1990a, Hydrogeology of the Cliff House Sandstone in the San Juan structural basin, New Mexico, Colorado, Arizona, and Utah: U.S. Geological Survey Hydrologic Investigations Atlas HA-720-E, 2 sheets.

1990b, Hydrogeology of the Ojo Alamo Sandstone in the San Juan structural basin, New Mexico, Colorado, Arizona, and Utah: U.S. Geological Survey Hydrologic Investigations Atlas HA-720-B, 2 sheets.

Trescott, P.C., 1975, Documentation of finite-difference model for simulation of threedimensional ground-water flow: U.S. Geological Survey Open-File Report 75-438, 32 p.

Tweto, Ogden, 1979, Geologic map of Colorado: U.S. Geological Survey, 2 sheets, scale 1:500,000.

U.S. Bureau of the Census, 1980, Master area reference file for 1980 Census.

1985, Technical documentation, population, and per capita income estimates: Governmental Units, Washington, D.C., 6 p.

U.S. Department of the Interior, 1986, Final environmental impact statement for the JackpilePaguate uranium mine reclamation project, Laguna Indian Reservation, Cibola County, New Mexico: U.S. Department of the Interior, 244 p.

U.S. Department of Commerce, n.d., Normal October' - April precipitation 1931-60: U.S. Department of Commerce Map, 1 sheet, scale 1:500,000.

U.S. Environmental Protection Agency, 1986a, Maximum contaminant levels (subpart B of part 141, National interim primary drinking-water regulations): U.S. Code of Federal Regulations, Title 40, Parts 100 to 149, revised as of July 1, 1986, p. 524-528.

U.S. Environmental Protection Agency, 1986b, Quality criteria for water, 1986: U.S. Environmental Protection Agency Publication EPA 440/5-86-001.

1986c, Secondary maximum contaminant levels (section 143.3 of part 143, National secondary drinking-water regulations): U.S. Code of Federal Regulations, Title 40, Parts 100 to 149 , revised as of July 1,1986 , p. 587-590.

1987, Municipal facility/waterbody computerized information, an introduction: U.S. Environmental Protection Agency.

U.S. Geological Survey, 1987, Digital elevation models: U.S. Geological Survey Data Users Guide 5, $51 \mathrm{p}$. 


\section{SELECTED REFERENCES--Concluded}

Waltemeyer, S.D., 1989, Statistical summaries of streamflow data in New Mexico through 1985: U.S. Geological Survey Water-Resources Investigations Report 88-4228, 204 p.

Waltemeyer, S.D., and Kernodle, J.M., 1992, Computation of snowpack-loss component for a water-budget model for the San Juan aquifer basin in New Mexico and Colorado: Proceedings, Western Snow Conference, Jackson, Wyo., April 14-16, 1992, p. 141-145.

Watson, R.A., and Wright, H.E., Jr., 1963, Landslides on the east flank of the Chuska Mountains, northwestern New Mexico: American Journal of Science, v. 261, June 1963, p. 525-548.

Welder, G.E., 1986, Plan of study for the Regional Aquifer-System Analysis of the San Juan structural basin, New Mexico, Colorado, Arizona, and Utah: U.S. Geological Survey WaterResources Investigations Report 85-4294, 23 p.

Welder, G.E., and Klausing, R.L., 1990, Geohydrology of the Morrison Formation in the western San Juan Basin, New Mexico: U.S. Geological Survey Water-Resources Investigations Report 89-4069, 1 sheet.

Wells, S.G., Love, D.W., and Gardner, T.W, eds., 1983, Chaco Canyon Country, A field guide to the geomorphology, Quaternary geology, paleoecology, and environmental geology of northwestern New Mexico: American Geomorphological Field Group 1983 Field Trip Guidebook, 253 p.

Wengerd, S.A., and Matheny, M.L., 1958, Pennsylvanian System of Four Corners region: American Association of Petroleum Geologists Bulletin, v. 42, no. 9, p. 2048-2106.

Wilson, E.D., Moore, R.T., and Cooper, J.R., 1969, Geologic map of Arizona: Arizona Bureau of Mines and U.S. Geological Survey, 1 sheet, scale 1:500,000.

Woodward, L.A., and Schumacher, O.L., 1973, Morrison Formation of southeastern San Juan Basin, New Mexico: Socorro, New Mexico Bureau of Mines and Mineral Resources Circular 129, 7 p.

Wright, A.F., 1979, Bibliography of geology and hydrology, San Juan Basin, New Mexico, Colorado, Arizona, and Utah: U.S. Geological Survey Bulletin 1481, 123 p.

Wright, H.E., Jr., 1954, Problem of Tohatchi Formation, Chuska Mountains, Arizona-New Mexico: American Association of Petroleum Geologists Bulletin, v. 38, no. 8, p. 1827-1836.

1956, Origin of the Chuska Sandstone, Arizona-New Mexico, a structural and petrographic study of a Tertiary eolian sediment: Geological Society of America Bulletin, v. 67, p. 413-434.

Wright, Robyn, 1984, Paleoenvironmental interpretation of the Upper Cretaceous Point Lookout Sandstone--Implications for shoreline progradation and basin tectonic history, San Juan Basin, New Mexico: Houston, Tex., Rice University, unpublished Ph.D. dissertation, 404 p.

Zehner, H.H., 1985, Hydrology and water-quality monitoring considerations, Jackpile uranium mine, northwestern New Mexico: U.S. Geological Survey Water-Resources Investigations Report 85-4226, 61 p., 1 pl. 